ARLETE ENI GRANERO

\title{
A LINGUAGEM DAS MARCAS DE CALÇADOS DA MODA: UM ENFOQUE PUBLICITÁRIO
}

São Paulo, 20 de outubro de 2006.

\section{Banca Examinadora}

ORIENTADORA: Dra. Yolanda Lhullier dos SANTOS.

Examinador 1

Gino Giacomini Filho

Examinador 2

Solange Martins Couceiro de Lima

Examinador 3

Lóris Graldi Rampazzo

Examinador 4

Paulo de Tarso Oliveira 
Tudo tem seu tempo e até certas manifestações mais vigorosas e originais entram em voga e saem de moda. Mas a sabedoria tem uma vantagem: é eterna.

Baltasar Gracián 
Ao meu maior mestre, o qual referencio, por toda sabedoria: meu Pai, ANTONIO GRANERO MARTINS +. 


\section{AGRADECIMENTOS}

À minha família, que sempre motivou o meu aprimoramento cultural.

À minha orientadora, Profa. Yolanda Lhullier dos Santos, por ter acreditado em meu potencial, pelas contribuições prestadas e atenção dispensada ao longo desse período.

Aos amigos Professores Ana Lúcia Furquim de Campos, Daniela de Figueiredo Ribeiro, Maria Esther Fernandes, Sheila Fernandes Pimenta e Oliveira e Sílvio de Carvalho Neto por terem contribuído com o trabalho, agregando sugestões de suma importância para o engrandecimento desse estudo.

À Indústrias de calçados Carmen Steffens, na pessoa de Roberta Facuri; Calçados Democrata, na pessoa de Rodrigo Magalini e, Indústria de Calçados Sândalo, na pessoa de Fernando Brigagão pela contribuição durante a pesquisa.

Aos estudantes Naína Correia de Sousa e Gabrielly Barbosa Ferreira, Mayra Dourado Pessoni e Ives de Lima pela contribuição durante a pesquisa.

A todos os universitários que participaram do grupo de discussão.

A todos que, de certa forma, contribuíram direta ou indiretamente para o desenvolvimento desta tese.

A todos, meus agradecimentos. 
RESUMO: o objetivo geral do estudo consiste em investigar os aspectos da linguagem da propaganda, das marcas escolhidas para o estudo de casos (Sândalo; Carmen Steffens e Democrata) utilizando como referencial a propaganda comercial (anúncios da mídia impressa) dos calçados da moda. Existe a necessidade de verificar dois aspectos fundamentais no processo de comunicação: o emissor e o receptor, respectivamente o profissional da área de marketing e o grupo de clientes. Sob o ponto de vista do profissional de marketing, o objetivo da ação, o posicionamento e a estratégia de comunicação; e sob o ponto de vista do consumidor, a percepção, a imagem, em relação às propostas teóricas e práticas das empresas. Adaptarem às mudanças solicitadas pelo mercado consumidor brasileiro, constitui o desafio das organizações. A metodologia empregada utiliza a divisão da pesquisa em três partes: a primeira trata de um levantamento bibliográfico constituído do conjunto de pensamentos de vários autores sobre os assuntos relacionados ao tema em estudo; a segunda parte apresenta uma pesquisa documental (mídia impressa) que resultou na coleta de um banco de dados composto por peças publicitárias de calçados das marcas veiculados em outdoors e revistas de moda no período de 2002 a 2006; e a terceira parte aborda a pesquisa qualitativa através de discussões nos grupos de foco (ou Focus Group) que tem o propósito de descobrir o olhar e a percepção do consumidor em relação aos aspectos da linguagem da propaganda. O estudo apresenta como conclusão que não há moda sem sujeitos. Esta idéia significa que na mensagem publicitária deverá existir uma prática lingüística referente ao exercício de uma subjetividade: um conjunto de exercícios de linguagem, baseados em palavras e em imagens, que remetam para a afirmação da existência de sujeitos na mensagem ou, à personalização das entidades comerciais. Pretende-se contribuir, com esse estudo, para um melhor entendimento das estratégias de comunicação utilizadas pelas marcas em estudo, da forma de participação social e cultural, e da influência sobre o comportamento dos jovens, assim como a discussão da relação dos conceitos: moda; propaganda; gestão da marca e branding.

Palavras-chaves: propaganda; moda; calçados; marca; branding. 
ABSTRACT: the general objective of the study is to investigate the aspects of the advertising language of the chosen brands for the study of cases (Sândalo; Carmen Steffens and Democrata) taking as a reference the commercial advertising (print media advertising) of the trendy shoes. It is necessary to consider two essential aspects in the communication process: the emitter and the receiver, respectively the marketing area professional and the clients' group. According to the marketing professional, the action objective, the positioning and the communication strategy; and according to the customer, the perception, the image in relation to the theoretical and practical proposals of the companies. The organizations aim at adapting to changes required by the Brazilian consuming market. The methodology applied uses the research division in three parts: the first considers a bibliographic raising made of the set of thoughts coming from different authors about the subjects related to the theme under study; the second part shows a documental research (print media) which resulted in the assessment of data bank made of shoe marketing campaigns displayed in billboards and fashion magazines from 2002 to 2006; the third part considers the qualitative research through the discussions in the focus groups which intend to discover the look and perception of the customer in relation to the aspects of the advertising language. The study concludes that there is no fashion without subjects. This idea indicates that in the advertising message there should be a linguistic practice related to the exercise of subjectivity: a set of language exercises based on words and images, which remit to the assertion of the existence of subjects in the message or to the personalization of the commercial groups. It is also the objective of this study to contribute to a better understanding of the communication strategies used by the studied brands, the cultural and social participation form, and the influence upon youngsters' behavior as well as the discussion of the concepts relation: fashion; advertising; brand management and branding.

Key Words: advertising, fashion; shoes; brand; branding 
RESUMEN: el objetivo general del estudio consiste en investigar los aspectos del lenguaje de la propaganda de las marcas elegidas para el estudio de casos (Sândalo, Carmen Steffens y Democrata) basándose en la propaganda comercial (anuncios en medios de prensa) de los calzados de moda. Existe la necesidad de averiguar dos aspectos fundamentales en el proceso de comunicación: el emisor y el receptor, respectivamente el profesional del área de marketing y el grupo de clientes. Bajo el punto de vista del profesional de marketing, el objetivo de la acción, el posicionamiento y la estrategia de comunicación; y bajo el punto de vista del consumidor, la percepción, la imagen, en relación a las propuestas teóricas y prácticas de las empresas. Adaptarse a los cambios solicitados por el mercado consumidor brasileño constituye el desafío de las organizaciones. La metodología empleada supone la división del estudio en tres partes: la primera trata de un levantamiento bibliográfico constituido del conjunto de pensamientos de varios autores sobre los asuntos relacionados al tema estudiado; la segunda parte presenta una investigación documental (media de prensa) que resultó en la colecta de un banco de datos compuesto por piezas publicitarias de calzados de las marcas difundidas en outdoors y revistas de moda en el periodo de 2002 a 2006; y la tercera parte aborda la investigación cualitativa a través de discusiones en grupos de foco (o Focus Group), cuyo propósito es descubrir cómo los aspectos del lenguaje de la propaganda son vistos y percibidos por el consumidor. El estudio se concluye con el hecho de que no hay moda sin sujetos. Esta idea significa que en el mensaje publicitario deberá existir una práctica lingüística que se refiere al ejercicio de una subjetividad: un conjunto de ejercicios de lenguaje, basados en palabras y en imágenes, que se refieran a la afirmación de la existencia de sujetos en el mensaje o a la personalización de las entidades comerciales. Se pretende contribuir, con esta investigación, para una mejor comprensión de las estrategias de comunicación utilizadas por las marcas estudiadas, del modo de participación social y cultural, y de la influencia sobre el comportamiento de jóvenes, así como la discusión de la relación entre conceptos como: moda, propaganda, gestión de marca y branding.

Palabras-claves: propaganda; moda; calzados; marca; branding. 


\section{SUMÁRIO}

INTRODUÇÃO

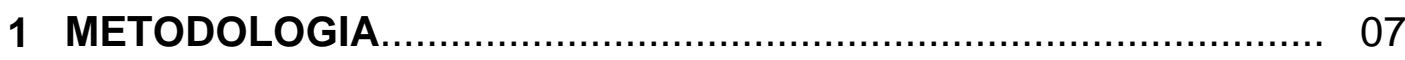

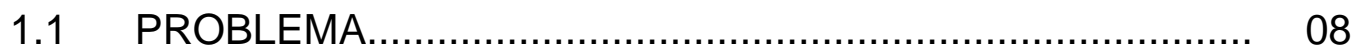

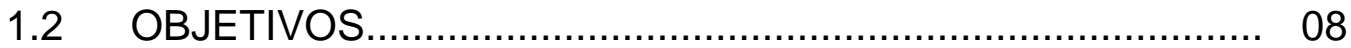

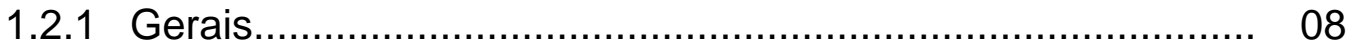

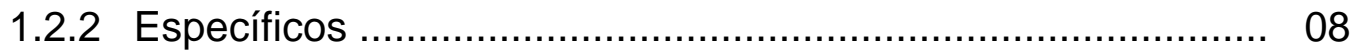

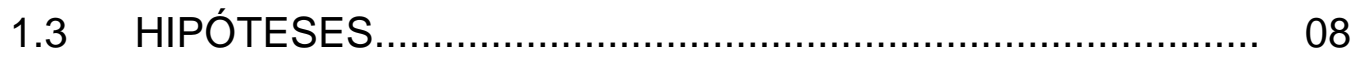

1.4 UNIVERSO DA PESQUISA E PROCEDIMENTOS METODOLÓGICOS..................................................... 09

1.4.1 Guia da Discussão em Grupo....................................... 14

2 DOS ASPECTOS TEÓRICOS DA COMUNICAÇÃO.................... 18

2.1 TEORIAS DA COMUNICAÇÃO................................ 19

2.1 .1 O Funcionalismo.......................................................... 19

2.1.2 Escola de Frankfurt e a Teoria Critica............................... 21

2.1.3 A Escola de Palo Alto ............................................... 31

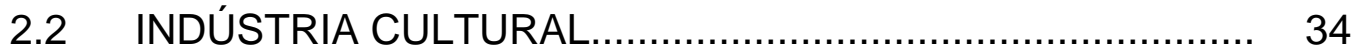

2.2.1 Indústria Cultural no Brasil..................................... 34

2.2.2 Cultura de Massa e Cultura Popular.................................... 35

2.3 SUJEITO CONTEMPORÂNEO.................................... 38

2.4 O PROBLEMA DO TEXTO ........................................... 43

2.5 ANÁLISE DO DISCURSO ........................................ 48

3 DAS FERRAMENTAS DE COMUNICAÇÃO........................... 58

3.1 PROPAGANDA ...................................................... 59 
3.2 LINGUAGEM DA PROPAGANDA..................................... 65

3.2.1 Variação Lingüística.................................................. 65

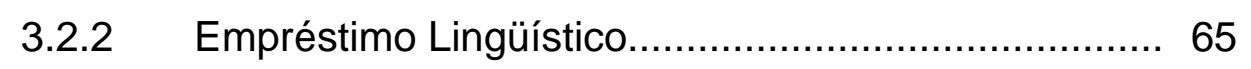

3.2.3 Aspectos Ortográficos............................................... 65

3.2.4 Aspectos Fonéticos................................................... 66

3.2.5 Aspectos Morfológicos............................................ 66

3.2.6 Aspectos Sintáticos............................................... 67

3.2.7 Aspectos Semânticos................................................ 68

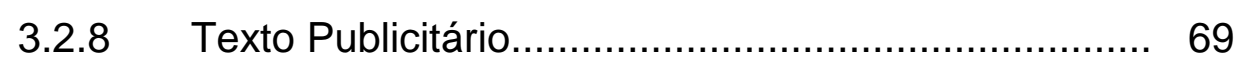

3.2.9 Figuras de Linguagem........................................ 69

3.2.10 Trocadilho....................................................... 69

3.2.11 Frase Feita..................................................... 70

3.2.12 Lugar Comum..................................................... 71

3.2.13 Associação de Palavras.......................................... 71

3.2.14 As correntes Espirituais e a Propaganda................. 72

3.2.15 O Minimalismo......................................................... 72

3.2.16 A Literatura.................................................... 72

3.2.17 Plágio e as Coincidências na Propaganda............... 73

3.3 GESTÃO DE MARCAS NA INDÚSTRIA DA MODA............... 74

3.3.1 As Marcas no Século XXI...................................... 79

.3 .4 O PODER DA MÍDIA..................................................... 84

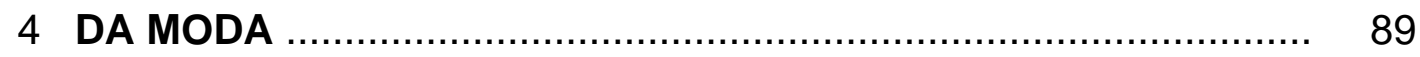

4.1 PANORAMA DA MODA: DA ERA PALEOLÍTICA AO

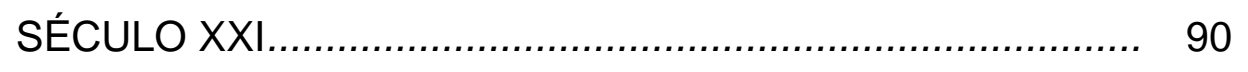

4.2 A HISTÓRIA DO SAPATO ................................................. 105 
4.2.1 O Salto ...................................................... 119

4.2.2 Artesanato à Indústria.............................................. 120

4.2.3 As Influências dos Sapatos.................................... 120

4.3 A MODA NO CONTEXTO SOCIAL..................................... 123

5 DESENVOLVIMENTO DA PESQUISA ............................................ 136

$5.1 \quad$ ESTUDOS DE CASOS.................................................... 137

5.1.1 Carmen Steffens............................................... 140

5.1.2 Calçados Democrata................................................ 141

5.1.3 Calçados Sândalo.................................................. 141

5.2 PESQUISA DOCUMENTAL............................................ 143

5.2.1 Análise e Interpretação............................................. 143

5.2.1.1 Carmen Steffens.............................................. 143

5.2.1.2 Calçados Democrata............................................. 158

5.2.1.3 Calçados Sândalo.............................................. 180

5.3 PESQUISA QUALITATIVA............................................... 195

5.3.1 Descrição................................................................ 195

5.3.2 Resultados..................................................... 196

5.3.2.1 Primeiro Grupo.................................................. 197

5.3.2.2 Segundo Grupo.................................................... 205

6 CONSIDERAÇÕES FINAIS ............................................. 212

7 LIMITAÇÕES E SUGESTÕES PARA ESTUdOS

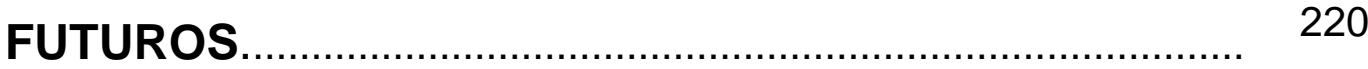




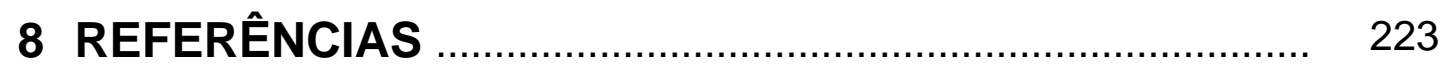

ANEXOS

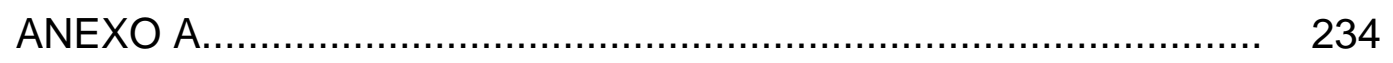

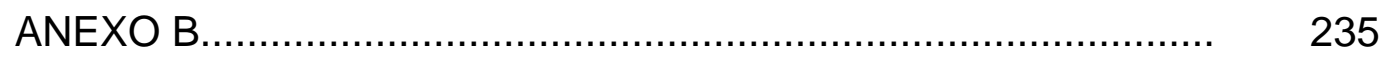

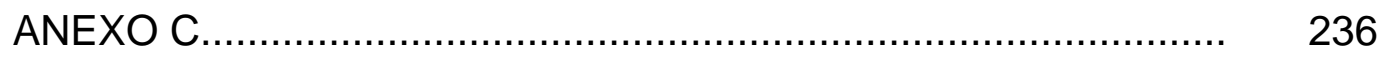

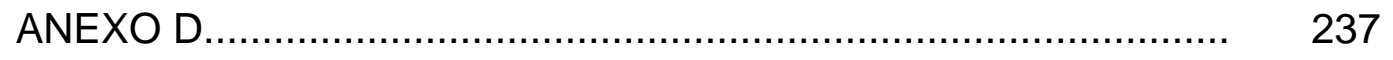

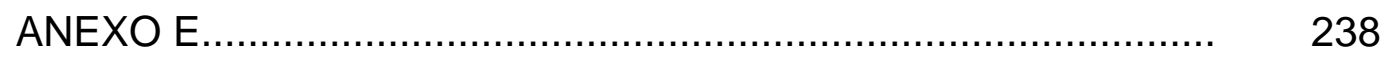

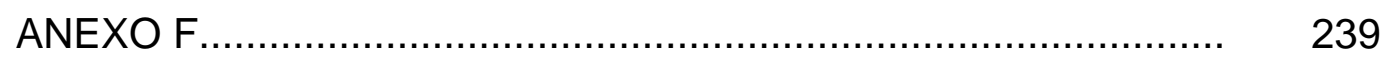

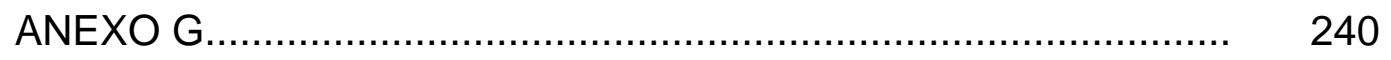

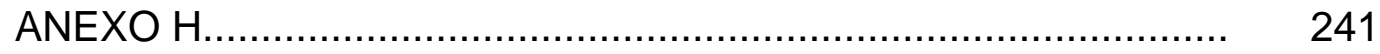

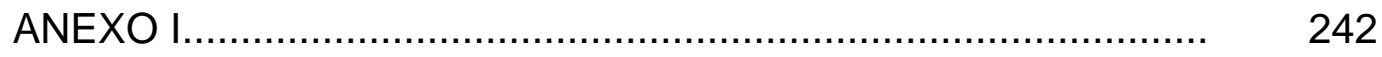

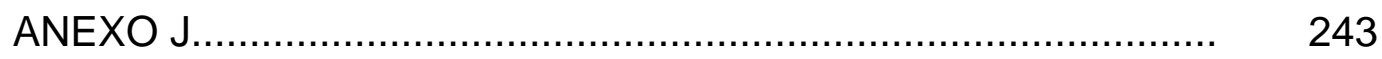

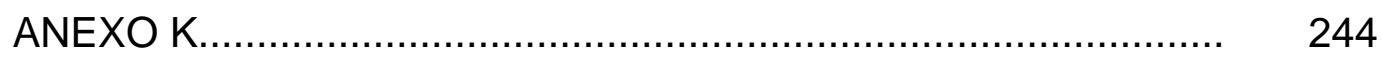




\section{LISTA DE FIGURAS}

1 Sapato em plástico vermelho cintilante............................... 112

$2 \quad$ Sapato de pele de lagarto................................................... 113

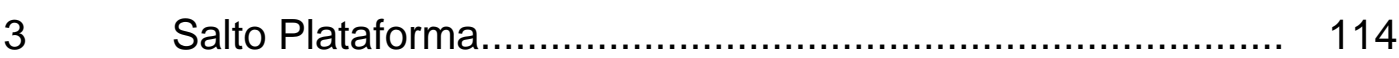

$4 \quad$ Sandália de plástico....................................................... 115

5 Sandália com wedges-soles de madeira pintada de branco... 116

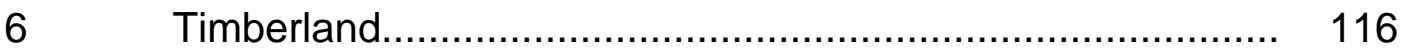

$7 \quad$ Tradicional Mocassim ...................................................... 118

$8 \quad$ A onda dos tênis............................................................ 119

$9 \quad$ Sapato de Camurça ...................................................... 120

10 Salto Stiletto ............................................................ 121

11 Sandálias Japonesas................................................. 122

12 Anúncio de Revista Marie Claire, julho 2005 e Banner........ 145

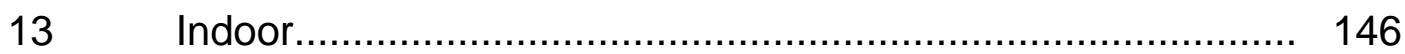

$14 \quad$ Outdoor.................................................. 146

$15 \quad$ Placa Teen Urban, verão 2005........................................ 147

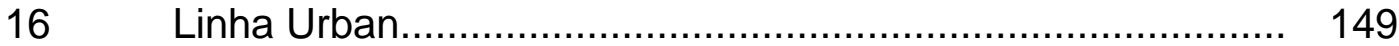

$17 \quad$ Natal 2005 ................................................................ 150

$18 \quad$ Outdoor, Inverno 2006.................................................... 151

19 Anúncio de revista, Outdoor e Indoor, Inverno 2006............. 152

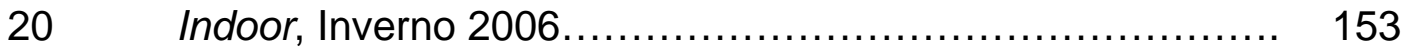

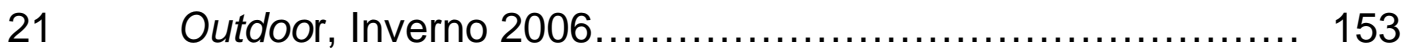

22 Revista 'Quem' 14/4/2006.............................................. 154 
$24 \quad$ Linha Urban Outono / Inverno 2006........................... 156

$25 \quad$ Linha Urban Outono / Inverno 2006.............................. 157

26 Anúncio de Revista - Dia dos Namorados № 1 - 2003........ 160

27 Anúncio de Revista - Dia dos Namorados No 2 - 2003........ 160

28 Anúncios de Revista - Dia dos Pais - 2003....................... 161

29 Anúncios de Revista - Coleção Outono Inverno - 2003....... 162

30 Anúncios de Revista - Coleção Primavera Verão - 2003...... 164

31 Anúncios de Revista - Coleção Primavera Verão - 2003..... 165

$32 \quad$ Anúncios de Revista - Dia dos Namorados - 200.............. 166

33 Anúncio Seqüencial de Revista - Coleção Outono Inverno -

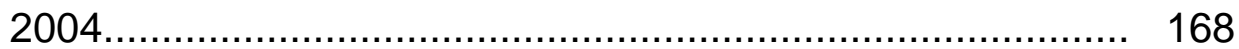

34 Anúncios de Revista - Coleção Outono Inverno - 2004....... 169

$35 \quad$ Anúncios de Revista - Dia dos Pais - 2004...................... 170

36 Anúncio Seqüencial de Revista - Coleção Primavera Verão - 171 2004

37 Anúncios de Revista - Coleção Primavera Verão - 2004..... 172

$38 \quad$ Anúncio de Revista - Dia dos Namorados - 2005.............. 173

39 Anúncios de Revista - Coleção Outono Inverno - 2005....... 174

$40 \quad$ Anúncios de Revista - Dia dos Pais - 2005.................... 175

$41 \quad$ Anúncios de Revista - Primavera Verão - 2005................ 176

$42 \quad$ Anúncios de Revista - Primavera Verão - 2005.................. 177

$43 \quad$ Anúncios de Revista - Dia dos Namorados - 2006............ 178

44 Anúncios de Revista - Coleção Outono Inverno - 2006...... 179

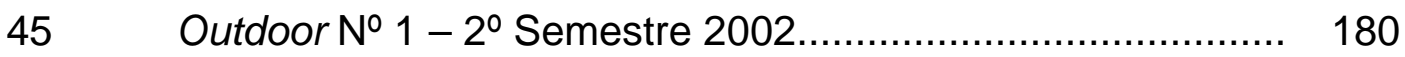




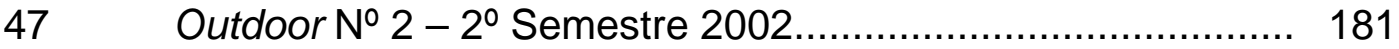

$48 \quad$ Anúncio de revista No $2-2^{\circ}$ Semestre $2002 \ldots \ldots \ldots \ldots \ldots \ldots \ldots \ldots \ldots \ldots \ldots$

$49 \quad$ Outdoor $N^{0} 1-1^{\circ}$ Semestre 2004.................................. 185

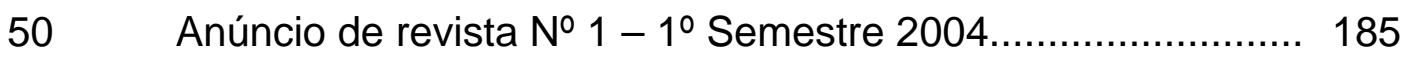

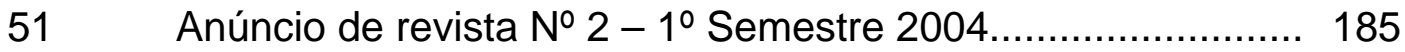

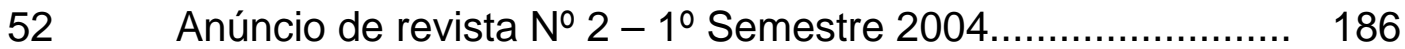

$53 \quad$ Anúncios Revista Couro Moda 2004.................................. 188

$54 \quad$ Anúncio de Revista Francal 2004.................................... 189

$55 \quad$ Anúncio de Revista 2004 - Linha Quest Hidra-Yoga........... 190

$56 \quad$ Outdoor № $1-2^{\circ}$ Semestre de 2005............................. 191

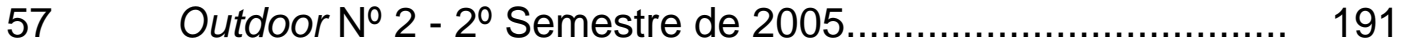

$58 \quad$ Anúncio de Revista № $1-2^{\circ}$ Semestre de $2005 \ldots \ldots \ldots \ldots \ldots . . . . . . .192$

59 Anúncio de Revista Couro Moda $N^{\circ} 1-2^{\circ}$ Semestre de

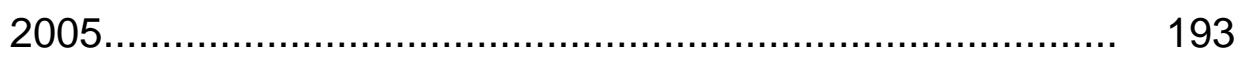

60 Fotos do Catálogo e site Coleção 2005/2006...................... 194 


\section{LISTA DE QUADROS}

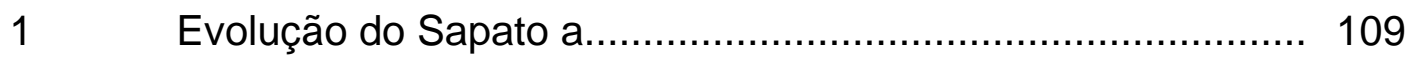

$2 \quad$ Evolução do Sapato b.......................................... 110 
MTRODUCGO 
O trabalho aqui apresentado surgiu da necessidade de estudar a linguagem da propaganda das marcas de calçados utilizados pela indústria da moda. O objetivo geral do estudo consiste em investigar os aspectos da linguagem da propaganda, das marcas escolhidas para o estudo utilizando como referencial a propaganda comercial (anúncios de mídia impressa) dos calçados da moda.

A curiosidade inicial sobre a linguagem da propaganda das marcas de calçados da moda apresentou maior evidência após a observação de anúncios na mídia impressa. As publicações mostram-se coloridas, graficamente arrojadas, persuasivas e atrativas. $O$ universo da pesquisa centra-se em uma temática cultural que é a moda, e mais especificamente sobre a moda no setor calçadista. Por isso, o enfoque analisado aborda a linguagem da propaganda das marcas de calçados constituindo o material documental da pesquisa.

A escolha pelo setor calçadista deve-se primeiramente à notoriedade do setor na economia do país. A principal região produtora de calçados do País em 2002 foi o Rio Grande do Sul, com 2.773 empresas, a maioria delas localizada no Vale dos Sinos, produzindo, sobretudo calçados femininos para exportação. A segunda região está situada em São Paulo, especialmente em Franca, com 2.092 empresas fabricantes de sapatos para 0 mercado interno e externo. São Paulo foi responsável, em 2002, pela exportação com 116 milhões de dólares e 8\% do total exportado. Atualmente o setor calçadista de Franca é composto por 360 indústrias de estrutura familiar que geram 16,9 mil empregos (GORINI; CORREA, 2000). Nesse cenário, a imagem dos produtos do setor calçadista no exterior não se vincula a referências industriais e sim à música, ao carnaval, ao futebol, ao mar e à praia. Conforme leitura de economistas:

No aspecto teórico, o estereotipo nacional é fundado sobre dois componentes: a dimensão cognitiva, isto é, quais os atributos aos quais os indivíduos se referem para caracterizar a imagem de um país, e a dimensão avaliativa, isto é, a avaliação de cada atributo sobre uma escala qualitativa. O Brasil deve, sobretudo, valorizar suas vantagens através de uma política intensa de comunicação internacional. A APEX (Agência de 
Promoção das Exportações) do Brasil está engajada nesta via difícil, mas indispensável para o futuro da indústria brasileira. A loja Printemps de Paris indicou que o Brasil tinha uma vantagem particular para artigos de moda (vestuário e sandálias) ligados à praia. Esta vantagem é, precisamente, ligada ao fato de que é percebida uma relação entre a criatividade das empresas brasileiras produtoras de artigos de verão e o estereotipo do Brasil que é fundado sobre a noção. As ações destinadas a desenvolver a imagem de um Brasil que apresenta um nível de tecnologia industrial apreciável devem se fundar sobre esforços de comunicação levando em conta critérios objetivos. É a qualidade do calçado brasileiro que reforçará, favoravelmente, em nível internacional, a notoriedade de seu produto. Em um dado país, se o conteúdo dessa atitude baseada sobre um conjunto de crenças é largamente partilhado pela população, podemos falar de estereotipo nacional (SUZIGAN; FURTADO; GARCIA; SAMPAIO. 2002).

É possível notar entre as empresas brasileiras de calçados um interesse crescente do desenvolvimento de estratégias competitivas baseadas no desenvolvimento do design e gestão de marca de seus produtos. A principal razão para esse fenômeno é que as empresas têm intensificado suas ações no sentido do lançamento de novos produtos, modelos e design, em uma tentativa de agregar valor aos seus produtos. Por outro lado, existem bem-sucedidas firmas nacionais que trilharam seu caminho pela via do mercado interno. Investindo em design e em marcas próprias, consolidou importantes posições no setor calçadista, o que posteriormente permite considerar e até mesmo efetivar a exportação de seus produtos e marcas, iniciando a conquista de segmentos de mercados internacionais.

No que diz respeito aos critérios de escolha das empresas da amostra buscou-se selecionar empresas que houvessem apresentado, nos últimos anos, melhor e mais visível desempenho do ponto de vista da inovação, especialmente no que se refere à gestão de marca e desenvolvimento de produto e design. Como o universo de empresas na indústria de calçados é muito grande, o processo de seleção da amostra procurou levar em conta as principais experiências de empresas que apresentaram avanços mais significativos em sua participação no mercado, na liderança em termos de lançamento de tendências de moda e na existência de estratégias mais arrojadas do posicionamento da marca. Além destes requisitos, houve a preocupação de reunir empresas que atuassem em ramos distintos do 
mercado de calçados, buscando um equilíbrio entre produtores de calçados masculinos e femininos, de couro e de outros materiais, sociais e esportivos.

Nesse sentido, a amostra foi composta pelas seguintes empresas:

> Sândalo;

$>$ Carmen Steffens;

$>$ Democrata.

O calçado é utilizado pelo homem como uma proteção contra as intempéries naturais como o frio, a chuva e o calor. $O$ ato de cobrir e proteger o corpo tornou-se uma forma de diferenciação da estrutura socioeconômica e cultural. Este ato é presente em todas as sociedades, que cobrem, enfeitam e adornam o corpo (LAVER, 1996). O ser humano veste o seu corpo e o adorna com símbolos que a sociedade sabe ler. 0 indivíduo faz uma opção de imagem frente ao seu grupo social e a sua construção visual - escolhe o que vestir e o que calçar. Assim o vestuário e seus acessórios caracterizam-se como fator de grande importância dentro de qualquer cultura. Os indivíduos podem demonstrar significados iguais ao grupo que pertencem ou diferentes frente aos outros grupos. As vestimentas têm o papel de comunicar diferentes temas culturais como religiosidade, beleza, tradições etc. As vestimentas protegem o corpo dos fatores naturais, climáticos e sociais.

As roupas e os calçados são comunicadores das crenças e ideais que retratam a cultura de uma população. $O$ vestuário ocidental e seus acessórios expressam o que a sociedade deve reconhecer nos indivíduos, assim como o lugar e as pessoas para o estabelecimento e a continuidade do relacionamento. Apresenta uma linguagem que marca a posição, uma mensagem do indivíduo para a sociedade. As vestimentas constituem fronteiras físicas e simbólicas entre as pessoas e o mundo. A moda é a forma como a sociedade ocidental atribui significados ao que veste, calça e usa como ornamento. Não se faz moda exclusivamente com roupas, nem só com o sapato ou a maquiagem, mas o conjunto harmônico de todos esses elementos. A roupa expressa o "querer ser" na sociedade aliada ao culto da individualidade que exige liberdade de 
expressão, destacando-se os sentimentos e pensamentos a partir das aparências. $O$ indivíduo comunica a sua maneira de pensar através da construção visual da vestimenta. A linguagem nasce do propósito de elaborar um sentido na construção da sua vestimenta e acessórios. Essa linguagem é falada e compreendida pelas pessoas, após a decodificação que os eventos da moda disponibilizam, isto é, atualizações do novo que informam o que é moda. Dentre esses meios de informação estão a TV, a revista, o cinema, a mídia exterior etc. Os meios de comunicação constituem a mediação entre os produtores de moda e público-alvo dessa linguagem de aparências, e esta leitura se faz ligada à idéia de uma sociedade organizada em grupos e ao mesmo tempo esses sujeitos pertencem ou circundam vários destes. Ao circularem por diversos grupos, as pessoas manipulam códigos de vestuário, e ao elaborar a sua própria aparência, que é reconhecida pelos vários grupos em que transita, o sujeito abre a leitura de sua vestimenta re-significando de acordo com os distintos grupos que percorre. A "rotulação" é utilizada para fazer a leitura dos que passam, mas pode apresentar erros. Desta forma, as pessoas podem ser classificadas de uma coisa e serem além dela. Conforme Becker (1971, p. 64), a identidade é o produto de um processo que envolve respostas de outras pessoas ao comportamento. $A$ aparência é construída para residir nos olhos do outro.

Existe a necessidade de verificar dois aspectos fundamentais no processo de comunicação: o emissor e o receptor, respectivamente o profissional da área de marketing e o grupo de clientes. Sob o ponto de vista do profissional de marketing, o objetivo da ação, o posicionamento e a estratégia de comunicação; e sob o ponto de vista do consumidor, a percepção, a imagem, em relação às propostas teóricas e práticas das empresas. Adaptarem às mudanças solicitadas pelo mercado consumidor brasileiro, constitui o desafio das organizações.

O processo de construção cultural gerado a partir da publicidade e da propaganda incidirá de forma crescente na relação radical no nível econômico, e social da atual população.

No Brasil (CENSO, 2000), são 55 milhões de jovens que nasceram no final da década de 70 , acumulando um poder de compra de 
130 milhões de dólares, com hábitos e necessidades específicas, que mudam com a velocidade imposta pela sociedade virtual. Reconhecer, entender e atender a esse público, acompanhar essas mudanças é o desafio para a criação. Quanto mais criativa a propaganda, maior será a sua aceitação. A propaganda terá espaço desde que exista uma identidade social a ser manipulada.

Em detrimento da relevância e da atualidade do estudo da linguagem da propaganda das marcas de vestuário da moda, o conhecimento acumulado sobre o mesmo até o momento mostra-se com interpretações distintas, porém é necessário à investigação e a reflexão que exige fundamentação teórica profunda.

Pretende-se contribuir, com esse estudo, para um melhor entendimento das estratégias de comunicação utilizadas pelas marcas em estudo, da forma de participação social e cultural, e da influência sobre o comportamento dos jovens, assim como a discussão da relação dos conceitos: moda; propaganda; gestão da marca e branding.

Esse trabalho estrutura-se em nove partes: a Introdução; a Metodologia do Estudo que apresenta os subitens: contextualização, Justificativa do tema, objetivos, hipóteses e procedimentos metodológicos; os Aspectos Teóricos da Comunicação, a Indústria Cultural e Cultura de Massa, Sujeito Contemporâneo, Problema do Texto e Análise do Discurso; as Ferramentas da Comunicação; a História da Moda abordando da Era Paleolítica ao Século XXI e a História do Sapato; o Desenvolvimento do estudo, a Análise e Interpretação dos Dados da Pesquisa Documental e Focus Group; os Resultados; seguido das Considerações Finais; das Limitações e Sugestões para Estudos Futuros; Referências e Anexos. 


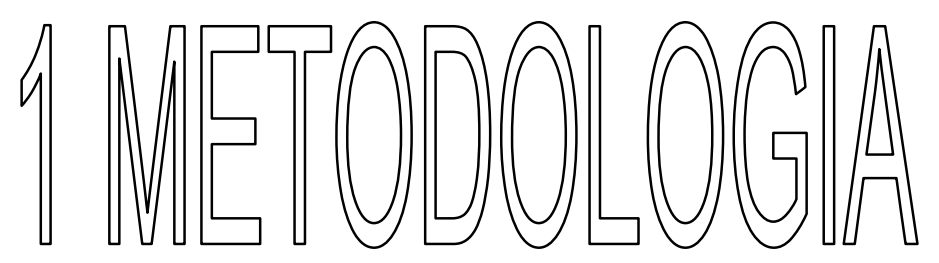




\subsection{PROBLEMA}

São vários os problemas de pesquisa decorrentes dos objetivos: qual é a linguagem das marcas de calçado da moda na propaganda brasileira? A moda é uma forma de participação social ou é uma forma meramente comercial? Até que ponto a Moda influencia a indústria de calçados? Existe a percepção e a consciência do consumidor sobre a influência da propaganda da moda de calçados nas suas atitudes?

\subsection{OBJETIVOS}

\subsubsection{Gerais}

O objetivo geral do estudo consiste em investigar os aspectos da linguagem da propaganda, das marcas escolhidas utilizando como referencial a propaganda comercial (anúncios da mídia impressa) dos calçados da moda.

\subsubsection{Específicos}

O trabalho de pesquisa tem como objetivos específicos:

1. identificar os elementos que caracterizam a marca;

2. identificar a linguagem da propaganda das marcas de calçados em estudo e sua influência junto aos jovens;

3. investigar a moda nos calçados como fator comercial;

4. levantar os significados e papéis assumidos pelas marcas de calçados de moda;

5. levantar a função da propaganda na difusão do conceito global dos calçados da moda;

\subsection{HIPÓTESES DO ESTUDO}

Para se prestar de guia ao raciocínio do pesquisador, Shelltiz et al (1974) sugere a conveniência da formulação de hipóteses aos empreendimentos investigatórios. Entretanto, as hipóteses em estudos descritivos quase sempre são especulativos. Geralmente, as relações 
estudadas não serão de natureza causal, entretanto elas podem ter utilidade para as previsões (AAKER; KUMAR; DAY, 2001). Neste sentido, foram formuladas as seguintes hipóteses:

H1: Existe o envolvimento das empresas de Moda de calçados nos programas de gestão de marca;

H2: A linguagem da propaganda agrega valor para as marcas na Indústria de Moda de calçado;

H3: A indústria da moda faz parte da globalização de idéias.

\subsection{UNIVERSO DA PESQUISA E PROCEDIMENTO METODOLÓGICO}

Este estudo utiliza a divisão da pesquisa em três partes: a primeira trata de um levantamento bibliográfico constituído do conjunto de pensamentos de vários autores sobre os assuntos relacionados ao tema em estudo. Essa parte visa trazer à tona conceitos, estudos, análises e reflexões já feitas por outros pesquisadores; com isso procura-se fazer uma cobertura ampla e mais atualizada possível a respeito do assunto. São levantamentos em livros, periódicos, artigos, documentos e outras formas de pesquisas de dados secundários. Procuram-se conduzir uma abordagem diversificada, focalizandose a atenção em outros aspectos correlatos que nos auxiliassem a abordar o assunto, os conceitos sob a visão de diversos autores. Neste estudo o uso da literatura serve para "moldar" o problema, assim como para uma revisão, e comparação entre autores e os resultados obtidos na prática.

A segunda parte apresenta uma pesquisa documental (mídia impressa) que resultou na coleta de um banco de dados composto por peças publicitárias de calçados das marcas Sândalo; Carmen Steffens e Democrata veiculados em outdoors e revistas de moda no período de 2002 a 2006. A condução dessa etapa proporcionou a leitura de cada anúncio, analisando a linguagem verbal e visual, seguindo os preceitos teóricos discutidos nos capítulos dois e três e a relevância para a compreensão das informações sobre a propaganda de cada uma das três marcas em estudo.

A terceira parte aborda a pesquisa qualitativa através de discussões nos grupos de foco (ou Focus Group) que tem o propósito de 
descobrir o que o consumidor tem em mente. É realizada para que possa se ter uma idéia de suas perspectivas, e ajuda o pesquisador a compreender 0 escopo e a complexidade das atividades e preocupações dos consumidores. $O$ uso do Focus Group é particularmente apropriado quando o objetivo é explicar como as pessoas consideram uma experiência, uma idéia ou um evento, visto que a discussão durante as reuniões é efetiva em fornecer informações sobre o que as pessoas pensam ou sentem ou, ainda, sobre a forma como agem (MATTAR, 1996).

Atualmente, para a ciência social, as duas principais técnicas de coleta de dados qualitativos são: a entrevista individual e a observação participante em grupos. O Focus Group, como uma entrevista em grupo, combina elementos dessas duas abordagens. A aplicação dessa técnica permite coletar dados em curto espaço de tempo e em quantidade adequada, embora não se possa argumentar com plena convicção sobre a espontaneidade das colocações emitidas pelos participantes.

$\mathrm{Na}$ etapa de planejamento do Focus Group foi desenvolvido um plano cronológico, incluindo as atividades de desenvolvimento das questões, a identificação das características dos participantes, a obtenção da lista dos potenciais participantes, o recrutamento dos participantes, a realização das reuniões, o feedback do planejamento, a transcrição, a análise e a redação do relatório. Foi abordado com maior detalhe: o número e o tamanho dos grupos, os participantes, o nível de envolvimento do moderador, o conteúdo da entrevista, a seleção do local e a coleta dos dados.

O grupo foi constituído de pessoas estranhas ou desconhecidos. Normalmente, as pessoas que se conhecem apresentam dificuldades em se concentrar imediatamente no tópico da pesquisa e essa condição também pode inibir ou restringir suas percepções (comentários). Neste sentido, Mattar (1996) afirma que, na seleção de participantes, deve ser evitado que em um mesmo grupo participem parentes, conhecidos, vizinhos ou amigos, evitando assim que relacionamentos existentes previamente predominem durante a reunião. Esta condição é importante para que haja identificação e integração entre os participantes durante a reunião, e para que não haja posições extremamente conflitantes entre os membros do grupo. 
Estudos de casos constituem a estratégia preferida quando as questões "como" ou "por que" são colocadas, quando o investigador tem pouco controle sobre eventos, e quando o foco repousa em um fenômeno contemporâneo dentro de um contexto de vida real. Os estudos de casos "explanatórios" também podem ser complementados por dois outros tipos: exploratório e descritivos, independente do tipo de estudos de casos, para superar as críticas tradicionais ao método (YIN, 1989, p. 13).

No estudo de casos, o pesquisador explora uma única entidade ou fenômeno (o caso) limitado pelo tempo e atividade (um programa, evento, processo, instituição, ou grupo social) e coleta informações detalhadas pelo uso de uma variedade de procedimentos de coleta de dados durante certo período de tempo (Idem, p. 27-30).

O desenvolvimento de projetos de pesquisa de estudo de casos é uma parte difícil de realizar, pois ainda não foram codificados. Coloquialmente, um projeto de pesquisa é um plano de ação de sair de um lugar e chegar a outro, onde "sair" pode ser definido como o conjunto inicial de questões a serem respondidas, e "chegar" é o conjunto de conclusões (respostas) em relação às perguntas. Entre o "sair" e o "chegar" pode-se encontrar várias etapas, incluindo a coleta e análise de dados relevantes. Nos projetos de estudos de casos há cinco componentes importantes: 1) questões do estudo; 2) proposições se houver; 3) unidade(s) de análise(s), ligação lógica entre os dados e as proposições; 4) critérios para interpretar os resultados (Idem, p. 2730).

Os métodos de pesquisa qualitativa são menos estruturados e mais intensivos que as entrevistas baseadas em questionários. Existe um relacionamento maior e mais flexível com o respondente, e os dados resultantes tem maior profundidade e maior riqueza de contexto. O número de respondentes é menor e apenas parcialmente representativo de qualquer população-alvo. Foi utilizada no estudo a categoria Clínica que se destina a obter insights sobre assuntos que seriam impossíveis de conseguir com métodos estruturados de pesquisa. O moderador investigou além do nível da consciência do consumidor (AAKER; KUMAR; DAY, 2001, p. 206). 
Os tópicos da discussão foram cuidadosamente predeterminados e seqüenciados, com base na análise da situação. A duração de cada sessão foi de uma hora e quarenta e cinco minutos.

O protocolo de pesquisa contém o instrumento de coleta e as normas gerais norteadoras de sua utilização. Na concepção de Yin (1989, p. 27-30), o protocolo proporciona maior confiabilidade à pesquisa e se faz desejável sob todas as circunstâncias e é essencial, quando se tratar de um projeto de caso múltiplo. Oferece os alicerces para a fase de coleta de dados, visando minimizar erros e vieses inerentes às pesquisas qualitativas.

Ainda segundo Yin (Idem, Ibidem), o protocolo é mais que um instrumento; contém o procedimento e regras gerais que devem ser seguidas no uso do instrumento, abrangendo preferencialmente, as seguintes partes: visão geral do estudo; procedimentos de campo; informações gerais e lembretes sobre procedimentos; roteiro do estudo de caso.

O contato com os participantes da discussão em grupo foi realizado da seguinte maneira:

- escolha dos participantes, feita de forma aleatória ;

- convite para a participação da discussão em grupo;

- contato - número de telefone e nome para agendamento da discussão;

- agendamento da discussão - contato telefônico;

- discussão em grupo - pontuados pela presença de anúncios de propaganda de marcas dos calçados em estudo, que marcam de forma definitiva os estilos de moda nacional, dando autonomia a essa linguagem de propaganda posicionando-a em lugar de destaque no cenário nacional e internacional.

Para a condução das sessões foi elaborado um guia de tópicos ou um roteiro de questões onde foram listados aspectos ou questões formadas apenas por palavras ou frases que lembrassem o moderador o tópico de interesse.

Essa forma parece mais espontânea para os participantes, bem como mais adequada, pois o moderador foi o mesmo para todas as sessões e 
o envolvimento do mesmo foi baixo em decorrência dos objetivos que incluem a análise de conteúdo.

Durante a introdução, o moderador fez uma breve apresentação dos tópicos de discussão e colocou algumas regras básicas, como: somente uma pessoa falaria por vez, não deveria existir conversa lateral, todos deviam ser encorajados a falar, etc. O grupo foi comunicado sobre a filmagem da sessão. A discussão teve início com a auto-apresentação de cada participante, o que serviu como quebra-gelo. A etapa seguinte foi a discussão propriamente dita. O moderador apresentou o primeiro tópico, que foi seguido por discussão não-estruturada até a introdução do segundo tópico, e assim sucessivamente; a entrevista de Focus Group incluiu doze questões classificadas em: (uma) questão aberta - a primeira rodada de perguntas da sessão foi feita a todos, de forma a permitir uma resposta rápida (10 a 20 segundos), e permitiu identificar as características que os participantes possuíam em comum; (uma) questão introdutória - introduziu o tópico geral da discussão e forneceu aos participantes oportunidades para refletir sobre experiências anteriores; (quatro) questões de transição - essas questões moveram a conversação para as questões-chave que nortearam o estudo; (cinco) questões-chave direcionaram o estudo. São as que necessitaram uma maior atenção e análise; (uma) questão-resumo - o moderador realizou um resumo, em dois ou três minutos, das questões-chave e partir daí aguardou o surgimento de idéias que emergiram da discussão.

A pesquisa foi realizada no dia 27 de junho de 2006 envolvendo dois grupos de onze pessoas compostos por: jovens de 18 a 24 anos, homens e mulheres, universitários ou estudantes, que consomem e também os que não consomem marcas (grifes) de calçados, escolhidos aleatoriamente por meio de contato pessoal em Instituições de Ensino Superior públicas e privadas. Os participantes foram recrutados observando as similaridades e os contrastes existentes entre elas.

Um relatório eficiente de uma sessão de Focus Group deve capturar toda a gama de impressões e observações de cada tópico e a interpretar sob a luz das possíveis hipóteses a serem testadas posteriormente. Quando se relata um comentário, não é suficiente apenas repetir o que foi dito, mas colocá-lo dentro do contexto, para que suas implicações fiquem mais 
evidentes. A análise foi sistemática, verificável e focada no tópico de interesse e com nível de interpretação apropriado. Cada sessão produziu aproximadamente 8 páginas de transcrições. Foram consideradas as palavras e os seus significados; o contexto em que foram colocadas as idéias; a consistência interna, a freqüência e a extensão dos comentários; a especificidade das respostas; e a importância de identificar as grandes idéias (AAKER; KUMAR; DAY. 2001, p. 215).

\subsubsection{Guia da Discussão em Grupo}

Texto do Moderador: "O objeto do estudo é o jovem e a sua relação com as marcas de calçados da moda, constituindo os sujeitos, dotados da capacidade crítica na mobilização da transformação da estrutura social".

\section{O que é estar na moda?}

Figura projetada para discussão: Anexo A

2. Como você define a Moda no setor de calçados?

Figura projetada para discussão: Anexo B

\section{Estar na moda é usar calçado de marca?}

Figura projetada para discussão: Anexo C

4. Quais são os elementos que caracterizam uma marca de calçado?

Figura projetada para discussão: Anexo D

5. Qual o significado do calçado de marca?

Figura projetada para discussão: Anexo E

6. Quais são os papéis assumidos pelas marcas de moda e quais são suas influências na vida de um jovem?

Figura projetada para discussão: Anexo F 
7. Quais são as relações entre os jovens e as marcas de calçados expostos por estes anúncios veiculados nas revistas de moda?

Figura projetada para discussão: Anexo G

8. Como a propaganda divulga a moda? Como ela atinge o jovem? Figura projetada para discussão: Anexo H

9. Qual o papel social da propaganda da moda de calçados?

Figura projetada para discussão: Anexo I

10. Qual a influência da propaganda da moda de calçados junto a um jovem?

Figura projetada para discussão: Anexo J

11. O que você valoriza em um calçado de marca? Quais detalhes são importantes?

Figura projetada para discussão: Anexo K

12. Esse foi um resumo adequado? Gostaria de sugerir algo para complementar?

\subsection{PERSPECTIVA TEÓRICA}

A fim de responder à problemática anteriormente construída, a pesquisa foi iniciada por uma abordagem bibliográfica: levantamento de livros, teses e dissertações, periódicos especializados nas reflexões sobre o objeto do estudo. Estão listados abaixo alguns dos autores pesquisados:

> Sant'Anna (1998), Barros et al (2001) , Carrazcoza (2003-2004), Costa e Talarico (1996), Cabral (1991), Boone e Kurtz (1995) apresentam os conceitos da Linguagem da propaganda do resultado de bons anúncios como a soma de informações rigorosamente armazenadas, codificadas, desestruturadas e processadas por brilhantes intuitivos;

$>$ os autores Pires (2004), Beltrão (1986), Bordenave (1977), Muniz Sodré (1996), Caparelli (1980), Costa 
(2002), Horkheimer e Adorno (2000) discutem aspectos da indústria cultural e da cultura de massa;

> Bakhtin (1992-1992), Barthes (1979), Baudrillard (20001995), Brandão (1994), Eco (2003-2002), Foucault (1997) dentre outros autores; aspectos da Teoria da Comunicação, Linguagem e Análise do Discurso;

> Gestão da Marca: Aaker et al (2001), Biel (1996), D'Alessandro e Owens (2002), Gracioso (2004), Martins (1999), Pinho (1996), Sampaio (2002), Schmitt e Simonson (2000);

> Pesquisa de Marketing: Yin (1989), Mattar (1996), Aaker et al (2001), Seragini e Guardado (2003);

> Alleres (2000) apresenta cada indivíduo como um comprador de beleza, de estética, de sonho a qualquer preço, aspira à mudança, ama a moda que reitifica e coisifica o indivíduo, faz de cada um, consumidores exacerbados. Acrescenta que a moda tem um poder de atração muito grande, com o seu caráter do novo, do extraordinário e do belo, fascinam, independentes de qualquer juízo de valor. Wajnman e Almeida (2002) apresentam as relações da moda, da comunicação e da cultura. Barnard (2003) discute a necessidade das pessoas em ser ao mesmo tempo sociáveis e individualistas. A moda e a indumentária é a forma pela qual esse complexo conjunto de desejos e exigências pode ser negociado. Souza (2005) desvenda a história cultural da moda da época através de crônicas, romances, pinturas, gravuras e fotografias); Lipovetsky (1989-1987) analisa a moda como fenômeno social, suas metamorfoses e conceitos. Inicialmente, aborda a emergência da moda no final da Idade Média, assim como as linhas principais de sua evolução a longo prazo;

> Torquato (1991) discute conceitos da comunicação e a integração interna - "Briga entre relações humanas versus públicas". Considerações sobre a comunicação com o mercado são pontuadas por Guaresshi (2000), Cobra (2000), Ribeiro (1999). 


\section{DOS ASPECTOS TEÓRICOS DA COMUNICACÃO}


Vários aspectos da comunicação têm sido objeto de estudos. Na Grécia Antiga, o estudo da Retórica, a arte de discursar e persuadir, era um assunto vital para estudantes. No início do século $X X$, vários especialistas começaram a estudar a comunicação como uma parte específica de suas disciplinas acadêmicas. A Comunicação começou a emergir como um campo acadêmico distinto em meados do século XX. Marshall McLuhan (2000), Theodor Adorno e Paul Lazarsfeld foram alguns dos pioneiros na área.

Os pesquisadores das áreas de ciências humanas, têm dado contribuições para a Teoria da Comunicação, especialmente a comunicação mediada, como fenômeno social. Entre as teorias, destacam-se o funcionalismo, a Escola de Frankfurt que crítica o funcionalismo e a escola de Palo Alto, que afirma que o receptor tem consciência e só aceita o que deseja. Do ponto de vista de Barbero (2001), o que o receptor compreende varia grandemente conforme a sua cultura.

\subsection{TEORIAS DA COMUNICAÇÃO}

\subsubsection{O Funcionalismo}

Funcionalismo é uma doutrina que compara a sociedade a um organismo onde as diferentes parcelas da mesma exercem um determinado papel necessário para o conjunto. Nas ciências sociais, especificamente na sociologia e na antropologia sociocultural, o funcionalismo (também chamado análise funcional) é uma filosofia sociológica que originalmente tentava explicar as instituições sociais como meios coletivos de satisfazer necessidades biológicas individuais. Mais tarde se concentrou nas maneiras como as instituições sociais satisfazem necessidades sociais, especialmente a solidariedade social. O funcionalismo é associado com Émile Durkheim e Talcott Parsons. Visto que a análise funcional estuda as contribuições feitas pelo fenômeno sociocultural para os sistemas dos quais fazem parte. 
funcionalmente integradas para formar um sistema estável e que uma mudança em uma instituição irá precipitar uma mudança em outras instituições; expressas por Durkheim e outros como uma analogia orgânica. $O$ funcionalismo, nascendo como uma alternativa a explicações históricas, foi uma das primeiras teorias antropológicas do século $X X$, até ser superada pela análise estruturo-funcional ou estrutural-funcionalismo (MERTON, 1978).

Nos anos 60, o funcionalismo era criticado por ser incapaz de se responsabilizar por mudanças sociais ou contradições estruturais e conflitos e dessa maneira frequentemente chamada teoria do consenso. No entanto, Durkheim usou uma forma radical de socialismo corporativo juntamente com explicações funcionalistas, o Marxismo reconhece contradições sociais e utiliza explicações funcionais, e a teoria evolucionária de Parsons descreve os sistemas e subsistemas de diferenciação e reintegração desse modo causando menos conflito temporário ante a reintegração. "O fato da análise funcional poder ser vista por alguns como de natureza conservadora e por outros como de natureza radical sugere que ela pode ser nem uma nem outra. Críticos mais fortes incluem o argumento epistemológico que diz que o funcionalismo tenta descrever instituições sociais apenas através de seus efeitos e assim não explica a causa desses efeitos, ou coisa alguma, e o argumento ontológico que a sociedade não pode ter "necessidades" como os seres humanos, e até que se a sociedade tem necessidades elas não precisam ser satisfeitas. Anterior aos movimentos sociais dos anos 60 , o funcionalismo foi a visão dominante no pensamento sociológico; depois daquele tempo a teoria de conflito desafiou a sociedade corrente, defendida pela teoria funcionalista. Conforme alguns opositores, a teoria funcionalista sustenta que conflito e disputa pelo status quo é danosa à sociedade, tendendo a ser a visão proeminente entre os pensadores conservadores (MARSHALL, 1994; MERTON, 1978).

O trabalho teórico na América Latina apresentou crescimento a partir de 1970, momento em que iniciou a reflexão sobre as teorias estrangeiras, como, por exemplo, a Teoria das Mediações, de Jesús MartinBarbero (2001). As teorias aplicam diferentes pesos para os componentes da comunicação. As primeiras afirmavam que tudo o que o emissor dissesse seria 
aceito pelo receptor (público). Em seguida, surge a Teoría Crítica, que analisa a transmissão/dominação ideológica na comunicação de massa, confome Horkheimer e Adorno (2000).

\subsubsection{Escola de Frankfurt e a Teoria Crítica}

Theodor Wiesengrund Adorno (1903-1969) foi um filósofo alemão que escreveu sobre sociologia, psicologia e música. Tornou-se "conhecido por escrever artigos em que aplicava conceitos marxistas também à filosofia e à música". Adorno ensinou na Universidade de Frankfurt durante dois anos, tendo imigrado para a Inglaterra em 1934 por causa da perseguição aos judeus (ele era judeu por parte do pai; a mãe italiana, daí o nome Adorno). Ensinou três anos na universidade de Oxford e, em 1938, partiu para os Estados Unidos, em exílio (1938-1946). Ali seria professor na universidade de Princeton e também na universidade da Califórnia através de um convite de Max Horkheimer para assumir uma pesquisa a serviço da Universidade - o projeto da Radio Research Projet. A América pareceu-lhe indiferenciada e contraditória. O país que mais celebrava e enaltecia a singularidade, a cada um procurar ser algo bem diferente dos demais, não parava de produzir e imprimir tudo igual. A imensa rede de atividades que cobria toda a cidade era regida apenas pela ideologia do negócio. Aprofundando-se no estudo da mídia norteamericana, entendeu que por detrás daquele aparente caos, onde rádios, filmes, revistas e jornais, atuavam de maneira livre e independente, havia uma espécie de monopólio ideológico cujo objetivo era a domesticação das massas. Quando o cidadão saía do seu serviço e chegava a sua casa, a mídia bombardeava, a todos, com programas de baixo nível, intercalados com anúncios carregados de clichês conformistas, fomentando a produção e ao consumo. Demonstrava à existência de uma influente indústria cultural que, de forma planejada, persuadia aos seus consumidores lugares comuns e banalidades, cujo objetivo era a reprodução do modelo do mecanismo econômico que pressionava a sociedade como um todo. Não havia nenhuma quebra entre a produção e o lazer e girava em função do grande sistema. Ou seja, tudo que causasse reflexão e inquietação era imediatamente banida pela indústria cultural. Adorno projetou-se como um dos críticos mais ácidos dos 
modernos meios de comunicação de massa (RÜDIGER, 2002). Percebeu que a mídia não se voltava apenas para suprir as horas de lazer ou dar informações aos seus ouvintes ou espectadores, mas fazia parte do que ele chamou de indústria cultural. Um imenso maquinismo composto por milhares de aparelhos de transmissão e difusão que visava produzir e reproduzir um clima conformista e dócil na multidão passiva. "A civilização atual a tudo confere um ar de semelhança" (MAURO, 1995).

Adorno manteve amizade e colaboração intelectual com Max Horkheimer, reconstruindo ambos, no regresso à Alemanha pós-nazi, a escola de Frankfurt, em 1923. Esta considerava que os indivíduos eram facilmente enganados pelo capitalismo e pelas indústrias culturais. $\mathrm{Na}$ opinião destes filósofos alemães, "as indústrias culturais produziam em série uma massa degradada de produtos pouco sofisticados e sentimentais que substituíam as formas de arte mais «difíceis» e críticas que poderiam realmente levar as pessoas a porem em questão a vida social. [...] Adorno conclui que os media são o produto das «indústrias culturais» que mantêm a população passiva, preservando o domínio do capitalismo e prejudicando a verdadeira felicidade" (PIRES, 2004, p. 141). Morreu em 1969, com a humilhação que estudantes ultra-esquerdistas o submeteram em plena sala de aula, durante a revolta de 1968/9 (HORKHEIMER; ADORNO; In: LIMA, 2000).

Se a tendência social objetiva da época encarna nas intenções subjetivas dos supremos dirigentes, são estes os que originalmente integram os setores mais potentes da indústria (Idem, p. 171).

Os múltiplos interesses dos pensadores de Frankfurt e o fato de não constituírem uma escola no sentido tradicional do termo, mas uma postura de análise crítica e uma perspectiva aberta para todos os problemas da cultura do século $\mathrm{XX}$, torna difícil a sistematização de seu pensamento. Pode-se, no entanto, salientar alguns de seus temas, chegando-se a compor um quadro de suas principais idéias. De Walter Benjamin, devem-se destacar reflexões sobre as técnicas fixas de reprodução da obra de arte, particularmente do cinema, e as conseqüências sociais e políticas resultantes; de Adorno, o conceito de 
"indústria cultural" e a função da obra de arte; de Horkheimer, os fundamentos epistemológicos da posição filosófica de todo o grupo de Frankfurt, tal como se encontram formulados em sua "teoria crítica"; e, finalmente, de Habermas, as idéias sobre a ciência e a técnica como ideologia. Benjamin considera que a natureza vista pelos olhos difere da natureza vista pela câmara, e esta, ao substituir o espaço onde o homem age conscientemente por outro onde sua ação é inconsciente, possibilita a experiência do inconsciente visual, do mesmo modo que a prática psicanalítica possibilita a experiência do inconsciente instintivo. Exibindo, assim, a reciprocidade de ação entre a matéria e o homem, o cinema seria de grande valia para um pensamento materialista. Adaptado adequadamente ao proletariado que se prepararia para tomar o poder, o cinema tornar-se-ia, em conseqüência, portador de uma extraordinária esperança histórica (MAURO, 1995; HOHLFELDT, 2001).

A indústria cultural, mediante suas proibições, fixa positivamente - como sua antítese, a arte de vanguarda - uma linguagem sua, com uma sintaxe e um léxico próprios (HORKHEIMER; ADORNO; In: LIMA, 2000, p. 176).

A análise de Benjamin mostra que as técnicas de reprodução das obras de arte, provocando a queda da aura, promovem a liquidação do elemento tradicional da herança cultural; mas, por outro lado, esse processo contém um germe positivo, na medida em que possibilita outro relacionamento das massas com a arte, dotando-as de um instrumento eficaz de renovação das estruturas sociais. Para Adorno, a postura otimista de Benjamin no que diz respeito à função possivelmente revolucionária do cinema desconsidera certos elementos fundamentais, que desviam sua argumentação para conclusões ingênuas. Embora devendo a maior parte de suas reflexões a Benjamin, Adorno procura mostrar a falta de sustentação de suas teses, na medida em que elas não trazem à luz o antagonismo que reside no próprio interior do conceito de "técnica". Segundo Adorno passou despercebido a Benjamin que a técnica se define em dois níveis: primeiro "enquanto qualquer coisa determinada intra-esteticamente" e, segundo, "enquanto desenvolvimento exterior às obras de arte". O conceito de técnica não 
deve ser pensado de maneira absoluta: ele possui uma origem histórica e pode desaparecer. Ao visarem à produção em série e à homogeneização, as técnicas de reprodução sacrificam a distinção entre o caráter da própria obra de arte e do sistema social. Por conseguinte, se a técnica passa a exercer imenso poder sobre a sociedade, tal ocorre, segundo Adorno, graças, em grande parte, ao fato de que as circunstâncias que favorecem tal poder são arquitetadas pelo poder dos economicamente mais fortes sobre a própria sociedade. Em decorrência, a racionalidade da técnica identifica-se com a racionalidade do próprio domínio. Essas considerações evidenciariam que, não só o cinema, como também o rádio, não deve ser tomado como arte. "O fato de não serem mais que negócios - escreve Adorno - bastam-Ihes como ideologia”. Enquanto negócios, seus fins comerciais são realizados por meio de sistemática e programada exploração de bens considerados culturais (HORKHEIMER; ADORNO; In: LIMA, 2000).

O termo Indústria cultural foi empregado pela primeira vez em 1947, quando da publicação da Dialética do lluminismo, de Horkheimer e Adorno. Este último, numa série de conferências radiofônicas, pronunciadas em 1962, explicou que a expressão "indústria cultural" visa a substituir "cultura de massa", pois esta induz ao engodo que satisfaz os interesses dos detentores dos veículos de comunicação de massa. Os defensores da expressão "cultura de massa" querem dar a entender que se trata de algo como uma cultura surgindo espontaneamente das próprias massas. Para Adorno, que diverge frontalmente dessa interpretação, a indústria cultural, ao aspirar à integração vertical de seus consumidores, não apenas adapta seus produtos ao consumo das massas, mas, em larga medida, determina o próprio consumo. Interessada nos homens apenas enquanto consumidores ou empregados, a indústria cultural reduz a humanidade, em seu conjunto, assim como cada um de seus elementos, às condições que representam seus interesses. A indústria cultural traz em seu bojo todos os elementos característicos do mundo industrial moderno e nele exerce um papel específico, qual seja o de portadora da ideologia dominante, a qual outorga significado a todo o sistema. A ideologia 
capitalista, e sua cúmplice, a indústria cultural contribui eficazmente para falsificar as relações entre os homens, bem como dos homens com a natureza, de tal forma que o resultado final constitui uma espécie de antiiluminismo. Considerando-se diz Adorno que o iluminismo tem como finalidade libertar os homens do medo, tornando-os senhores e liberando o mundo da magia e do mito, e admitindo-se que essa finalidade pode ser atingida por meio da ciência e da tecnologia, tudo levaria a crer que o iluminismo instauraria o poder do homem sobre a ciência e sobre a técnica. Mas ao invés disso, liberto do medo mágico, o homem tornou-se vítima de novo engodo: o progresso da dominação técnica. Esse progresso transformou-se em poderoso instrumento utilizado pela indústria cultural para conter o desenvolvimento da consciência das massas. A indústria cultural nas palavras do próprio Adorno "impede a formação de indivíduos autônomos, independentes, capazes de julgar e de decidir conscientemente". O próprio ócio do homem é utilizado pela indústria cultural com o fito de mecanizá-lo, de tal modo que, sob o capitalismo, em suas formas mais avançadas, a diversão e o lazer tornamse um prolongamento do trabalho. Para Adorno, a diversão é buscada pelos que desejam esquivar-se ao processo de trabalho mecanizado para colocar-se, novamente, em condições de se submeterem a ele. A mecanização conquistou tamanho poder sobre o homem, durante o tempo livre, e sobre sua felicidade, determinando tão completamente a fabricação dos produtos para a distração, que o homem não tem acesso senão a cópias e reproduções do próprio trabalho. $O$ suposto conteúdo não é mais que uma pálida fachada: o que realmente lhe é dado é a sucessão automática de operações reguladas. Em suma, diz Adorno, "só se pode escapar ao processo de trabalho na fábrica e na oficina, adequando-se a ele no ócio" (HORKHEIMER; ADORNO; In: LIMA, 2000).

Tolhendo a consciência das massas e instaurando o poder da mecanização sobre o homem, a indústria cultural cria condições cada vez mais favoráveis para a implantação do seu comércio fraudulento, no qual os consumidores são continuamente enganados em relação ao que Ihes são prometidos, mas não cumprido. Exemplo disso encontra-se nas situações eróticas apresentadas pelo cinema. Nelas, o desejo suscitado 
ou sugerido pelas imagens, ao invés de encontrar uma satisfação correspondente à promessa nelas envolvida, acaba sendo satisfeito com o simples elogio da rotina. Não conseguindo, escapar a esta última, o desejo divorcia-se de sua realização que, sufocada e transformada em negação, converte o próprio desejo em privação: A indústria cultural não sublima o instinto sexual, como nas verdadeiras obras de arte, mas o reprime e sufoca. Ao expor sempre como novo o objeto de desejo (o seio sob o suéter ou o dorso nú do herói desportivo), a indústria cultural não faz mais que excitar o prazer preliminar não sublimado que, pelo hábito da privação, converte-se em conduta masoquista. Assim, prometer e não cumprir, ou seja, oferecer e privar são um único e mesmo ato da indústria cultural. A situação erótica, conclui Adorno, une "à alusão e à excitação, a advertência precisa de que não se deve, jamais, chegar a esse ponto". Tal advertência evidencia como a indústria cultural administra o mundo social.

O estilo da indústria cultural, que não tem mais de se afirmar sobre a resistência do material, é, ao mesmo tempo, a negação do estilo. A conciliação do universal e do particular, regra e instância específica do objeto, só por cuja atuação o estilo adquire peso e substância, é sem valor porque já não se cumpre qualquer tensão entre os dois pólos extremos que se tocam, são eles transpassados por uma identidade, o universal pode substituir o particular e vice-versa. Esta caricatura do estilo, contudo, diz alguma coisa sobre o estilo autêntico do passado. $O$ conceito de estilo autêntico se desmascara, na indústria cultural, como o equivalente estético da dominação. A idéia do estalo como coerência puramente estética é uma imaginação retrospectiva dos românticos (HORKHEIMER; ADORNO; In: LIMA, 2000, p. 178).

Criando "necessidades" ao consumidor (que deve contentarse com o que lhe é oferecido), a indústria cultural organiza-se para que ele compreenda sua condição de mero consumidor, ou seja, ele é apenas e tão-somente um objeto daquela indústria. Desse modo, instaura-se a dominação natural e ideológica. Tal dominação tem sua mola motora no desejo de posse constantemente renovado pelo progresso técnico e científico, e sabiamente controlado pela indústria cultural. Nesse sentido, o universo social, além de configurar-se como um universo de "coisas", constituiria um espaço hermeticamente fechado. Nele, todas as tentativas 
de liberação estão condenadas ao fracasso. Contudo, Adorno não desemboca numa visão inteiramente pessimista, e procura mostrar que é possível encontrar-se uma via de salvação (Idem).

Em Teoria Estética "Adorno oscila entre negar a possibilidade de produzir arte depois de Auschwitz e buscar nela refúgio ante um mundo que o chocava, mas que ele não podia deixar de olhar e denominar". Essa postura foi extremamente criticada pelos movimentos de contestação radical, que o acusavam de buscar refúgio na pura teoria ou na criação artística, esquivando-se assim da práxis política. Aos seus detratores, Adorno responde que, embora plausível para muitos, o argumento de que contra a totalidade bárbara não surtem efeito senão os meios bárbaros, na verdade não releva que, apesar disso, atinge-se um valor limite. As violências que há cinqüenta anos podia parecer legítima àqueles que nutrissem a esperança abstrata e a ilusão de uma transformação total está, após a experiência do nazismo e do horror stalinista, inextricavelmente imbricada naquilo que deveria ser modificado (MAURO, 1995).

Criticando a práxis brutal da sobrevivência, a obra de arte, para Adorno, apresenta-se, socialmente, como antítese da sociedade, cujas antinomias e antagonismos nela reaparecem como problemas internos de sua forma. Por outro lado, entre autor, obra e público, a obra adquire prioridade epistemológica, afirmando-se como ente autônomo. Esse duplo caráter vincula-se à própria natureza desdobrada da arte, que se constitui como aparência. Ela é aparência por sua diferença em relação à realidade, pelo caráter aparente da realidade que pretende retratar, pelo caráter aparente do espírito do qual ela é uma manifestação; a arte é até mesmo aparência de si própria na medida em que pretende ser o que não pode ser: algo perfeito num mundo imperfeito, por se apresentar como um ente definitivo, quando na verdade é algo feito e tornado como é (HORKHEIMER; ADORNO; In: LIMA, 2000).

A expressão "teoria crítica" é empregada para designar o conjunto das concepções da Escola de Frankfurt. Horkheimer delineia seus traços principais, tomando como ponto de partida o marxismo e opondo-se àquilo que ele designa pela expressão "teoria tradicional". 
Para Horkheimer, o típico da teoria marxista é, por um lado, não pretender qualquer visão concludente da totalidade e, por outro, preocupar-se com o desenvolvimento concreto do pensamento. Desse modo, as categorias marxistas não são entendidas como conceitos definitivos, mas como indicações para investigações ulteriores, cujos resultados retroajam sobre elas próprias. Quando se vale, nos mais diversos contextos, da expressão "materialismo" não repete ou transcreve simplesmente o material codificado nas obras de Marx e Engels, mas reflete esse materialismo segundo a visão dos momentos subjetivos e objetivos que devem entrar na interpretação desses autores. Por teoria tradicional Horkheimer entende a concepção de ciência resultante do longo processo de desenvolvimento que remonta ao Discurso do Método de Descartes (1596-1650). Descartes - diz Horkheimer - fundamentou o ideal de ciência como sistema dedutivo, no qual todas as proposições referentes a determinado campo deveriam ser ligadas de tal modo que a maior parte delas pudesse ser derivada de algumas poucas. Estas formariam os princípios gerais que tornariam mais completa a teoria, quanto menor fosse seu número. A exigência fundamental dos sistemas teóricos construídos dessa maneira seria a de que todos os elementos assim ligados o fossem de modo direto e não contraditório, transformando-se em puro sistema matemático de signos. Por outro lado, a teoria tradicional encontrou amplas justificativas para um tipo de ciência no fato de que os sistemas assim construídos são extremamente aptos à utilização operativa, isto é, sua aplicabilidade prática é muito vasta (HORKHEIMER; ADORNO; In: LIMA, 2000).

Horkheimer admite a legitimidade e a validez de tal concepção, reconhecendo o quanto ela contribuiu para o controle técnico da natureza, transformando-se, como diz Marx, em "força produtiva imediata". Mas o reverso da moeda é negativo. Para Horkheimer, o trabalho do especialista, dentro dos moldes da teoria tradicional, realizase desvinculado dos demais, permanecendo alheio à conexão global dos setores da produção. Nasce assim a aparência ideológica de uma autonomia dos processos de trabalho, cuja direção deve ser deduzida da natureza interna de seu objeto. $O$ pensamento cientificista contenta-se 
com a organização da experiência, a qual se dá sobre a base de determinadas atuações sociais, mas o que estas significam para o todo social não entra nas categorias da "teoria tradicional". Em outros termos, a teoria tradicional não se ocupa da gênese social dos problemas, das situações reais na qual a ciência é usada e dos escopos para os quais é usada. Chega-se, assim, ao paradoxo de que a ciência tradicional, exatamente porque pretende o maior rigor para que seus resultados alcance a maior aplicabilidade prática, acaba por se tornar mais abstrata, muito mais estranha à realidade (enquanto conexão mediatizada da práxis global de uma época) do que a teoria crítica. Esta, dando relevância social à ciência, não conclui que o conhecimento deva ser pragmático; ao contrário, favorece a reflexão autônoma, segundo a qual a verificação prática de uma idéia e sua verdade não são idênticas (MAURO, 1995).

A teoria crítica ultrapassa, assim, o subjetivismo e o realismo da concepção positivista, expressão mais acabada da teoria tradicional. "Pré-formados socialmente de dois modos: pelo caráter histórico de objeto percebido e pelo caráter histórico do órgão que percebe". Em suma, a teoria crítica de Horkheimer pretende que os homens protestem contra a aceitação resignada da ordem totalitária. A "razão polêmica", ao se opor à razão instrumental e subjetiva dos positivistas, não evidencia somente uma divergência de ordem teórica. Ao tentar superar a razão formal positivista, não visa suprimir a discórdia entre razão subjetiva e objetiva através de um processo puramente teórico. Essa dissociação somente desaparecerá quando as relações entre os seres humanos, e destes com a natureza, vierem à configurar-se de maneira diversa da que se instaura na dominação. A união das duas razões exige o trabalho da totalidade social, ou seja, a práxis histórica (Idem).

Jürgen Habermas (MCCARTHY, 1995) desenvolve sua teoria no mesmo sentido de Horkheimer. Para ele, a teoria deve ser crítica, engajada nas lutas políticas do presente, e construir-se em nome do futuro revolucionário para o qual trabalha; é exame teórico e crítico da ideologia, mas também crítica revolucionária do presente. Seu projeto filosófico pode ser sintetizado em termos de uma crítica do positivismo e, da ideologia dele resultante, o tecnicismo. O tecnicismo é a ideologia que 
consiste na tentativa de fazer funcionar na prática, e a qualquer custo, o saber científico e a técnica que dele possa resultar. Nesse sentido, podese falar de um imbricamento entre ciência e técnica, pois esta, embora dependa da primeira, retroage sobre ela, determinando seus rumos. Contra a ilusão da teoria pura, procura trazer à tona as raízes antropológicas da prática teórico-científica e evidenciar os interesses, que estão no princípio do conhecimento, particularmente do conhecimento científico. No plano da filosofia social, Habermas critica o objetivismo ontológico e contemplativo da filosofia teórica tradicional. Para ele, em nenhum caso a filosofia poderia ser propriamente uma ciência exata, e as pretensões que ela pode (e poderá) manifestar nesse sentido não fazem senão testemunhar sua contaminação pelo objetivismo positivista das ciências; nesse contexto ela não é mais que uma especialidade entre outras, no seio da instituição universitária, colocando-se "junto às ciências" e afastada das preocupações de um público leigo, devido a seus refinamentos teóricos.

Herbert Marcuse (DORIA, 1974) nasceu em Berlim em agosto de 1898, sendo de origem judaica, Com a ascensão do nazismo, foge em 1933 para Genebra, e em 1934 se instala nos Estados Unidos, ao lado dos sociólogos, também neo-hegelianos, Max Horkheimer e Theodor Wiesengrund Adorno. Começa então um longo período de pesquisas com estes dois, e com a equipe que constituía o centro da intelligentzia alemã exilada nos Estados Unidos por causa de Hitler: o "Institut Für SozialForschung", o "Instituto de Pesquisas Sociais". Desta época deixou-nos Marcuse enorme quantidade de ensaios que apresentam os germens das teses a serem desenvolvidas nos livros de sua maturidade: a preocupação com o desenvolvimento incontrolado da tecnologia, o racionalismo dominante nas sociedades modernas, os movimentos repressivos das liberdades individuais, o aniquilamento da Razão - e por Razão entende Marcuse o sentido hegeliano deste conceito, a possibilidade do homem desenvolver inteira e livremente suas potencialidades. A Razão é a faculdade humana que se manifesta no uso completo feito pelo homem de suas possibilidades. Não se pode compreender a "possibilidade" longe do conceito de "necessidade". A necessidade dirige os objetos cuja falta 
é sentida. A possibilidade mede o raio de alcance em face de tais objetos. Como pensador, é, acima de tudo, radicalmente dialético e crítico: a crítica ao modo de vida atual significa a manifestação de um dos lados daquela negatividade que Marcuse identificará como sendo o núcleo da dialética em Hegel (a dialética sob forma triádica: tese, antitese e síntese é uma máscara sobre o que este conceito representava mesmo para Hegel). Em Freud encontra a possibilidade de o homem ser feliz. O que faz o homem infeliz é que o mundo bloqueia a realização de seus desejos. Esta oposição do mundo a nós foi chamada por Freud "princípio da realidade". Para Marcuse, o princípio da realidade resulta de condições históricas específicas, isto é, a infelicidade é um fenômeno inseparável de determinadas situações sociais. Assim sendo, quando atinge a situação social correta, o homem pode ser feliz. O problema da sociedade moderna é a invasão da mentalidade mercantilista e quantificadora a todos os domínios do pensamento. Essa mentalidade se representa economicamente pelo valor de troca, ligado de modo íntimo aos processos de alienação do homem. E, segundo Marx na sua obra referida, os Fundamentos, com o desenvolvimento extremo da tecnologia "a forma de produção assente no valor de troca sucumbirá". A sociedade moderna, sentindo, que sua base na tecnologia - contém seu rompimento, age repressivamente para evitar este avanço extremo.

\subsubsection{A Escola de Palo Alto}

Palo Alto é uma cidade localizada no Estado americano de Califórnia, no Condado de Santa Clara. A cidade é a sede da Escola de Palo Alto, é uma universidade que constitui hoje um dos núcleos de investigação mais prestigiados no âmbito psicoterapêutico e psiquiátrico. O seu fundador era um apaixonado pelo saber científico e, numa perspectiva ecológica da mente (mind), socorreu-se de conceitos cibernéticos para compreender os processos da psiquê humana, no pressuposto da similitude formal que acreditava existir no funcionamento de todos os seres vivos.

Os Estudos Culturais são um campo acadêmico de pesquisa sobre comunicação e cultura, geralmente relacionando-as sob uma perspectiva político-econômica de orientação marxista. Criados pelos pesquisadores 
anglófonos Richard Hoggart, Raymond Williams, E. P. Thompson, consolidaram a partir do trabalho do anglo-jamaicano Stuart Hall: diretor do Centro de Estudos Culturais Contemporâneos (CCCS) da Universidade de Birmingham entre 1969 e 1979. Seus antecedentes foram o movimento no campo dos estudos literários e debate gerado pela Escola de Frankfurt, tendo como motivo gerador as alterações dos valores tradicionais da classe trabalhadora na Inglaterra do pós-guerra. Os pressupostos fundamentais são a análise da ação da mídia, atentando sobre as estruturas sociais e o contexto histórico como fatores essenciais para a compreensão da ação desses meios. Ocorre o deslocamento do sentido de cultura da sua tradição elitista para as práticas cotidianas (VERÓN, 1977).

A cultura tem relação com produção e intercâmbio de sentidos, isto é, o dar e receber sentidos entre os membros de uma sociedade ou grupo. Assim, a cultura deixa de ser considerada algo passivo e incorpora um sujeito que pode criar e agir sobre as coisas. No campo da comunicação, o interesse nas tecnologias é despertado. A cultura não significa simplesmente sabedoria recebida ou experiência passiva, mas um grande número de intervenções que podem tanto mudar a história ou transmitir o passado. É uma região de disputas e de conflitos acerca do sentido; diz respeito aos enfrentamentos entre modos de vida diferentes devido à existência de relações de poder. A comunicação é vista como um processo simbólico através do qual a realidade é produzida, reproduzida e transformada. Adquire um sentido especial 0 processo de recepção: esta é tratada como um processo social complexo que envolve atividade contínua de apropriações, usos e reelaborações de conteúdos por parte de indíviduos, estruturados em grupos sociais particulares. Desenham-se enlaces entre texto - contexto - receptores. A cultura, nessa teoria, passa a ser uma forma superior de ordenamento que se diferencia dos sistemas biológicos; para Lévi-Strauss os fenômenos sociais devem ser entendidos como processos de comunicação delimitados por sistemas de regras. Segundo a perspectiva de Verón (1977. [s.p.]):

Comunicação vista como instituição social, como conjunto de regras que estruturam as significações, na mesma linha de Saussure. A antropologia de Lévi-Strauss rompeu com a concepção funcionalista etnocêntrica, no entanto serviu como 
um alicerce para as tendências formalistas em ciências sociais. Foi assim, que a possibilidade de tratamento formal, com auxílio de instrumentos matemáticos, para as ciências humanas constituiu um fator estimulante para aqueles que "reverenciavam" os números; essa alternativa, no caso de Verón, deve ter sido muito provocativa, considerando-se sua preferência pelos computadores e pelos formalismos lógicos naquela época. É importante, por outro lado, verificar como a pesquisa antropológica estruturalista situou a problemática da comunicação no centro da organização social; questão que, depois de várias décadas (anos 70 e 80 do século XX), tornarse-ia o ponto crucial dos debates sobre o período pósmoderno, pós-industrial e tecnotrônico.

Verón (1977) situava uma convergência entre estruturalismo, psicanálise e marxismo que, de uma ou outra forma, presumia que a verdadeira significação inconsciente pode ser reconstruída a partir da conduta. Esse suposto gerou uma série de proposições a respeito da possibilidade teórica de interpretar sistemas latentes mediante uma observação científica e sistemática que poderia reconstituir os sistemas conscientes de representação.

A comunicação deixa de ser o modelo mecânico-técnico, e apresenta complexidade e abrangência. No nível teórico a definição dos vínculos da comunicação com a práxis social, com a cultura, com a história. No nível metódico o reconhecimento como um sistema de elementos descontínuos (signos, componentes de mensagens, mitos, etc.). Nos anos 80, tem um rompimento não só com o marxismo, mas também com o estruturalismo e com a semiologia de Saussure. Nesse ínterim, abre sua perspectiva semiótica, passando dos esquemas semiológicos tipo Greimas para uma visão mais sociológica e histórica da produção de sentido (discursos sociais), e valorizando esses conjuntos de sentido na sua realidade empírica, nos meios ou nas falas das pessoas. $\mathrm{O}$ formalismo das variáveis, componentes e relações estruturais preestabelecidas e o autoritarismo lingüístico dão passo a uma visão mais centrada e concreta dos processos sociais de produção de sentido. O paradoxo dialético, contudo, apresenta-se no estabelecimento do lugar que ocuparia a teoria dos discursos sociais na pesquisa em ciências humanas: $O$ centro, o núcleo, o eixo principal de interpretação dos processos políticos, sociológicos, antropológicos, mediáticos e históricos, na ótica de Verón, é sua teoria dos discursos sociais. Rompeu com as formas binárias de Saussure, com o estruturalismo, com o posicionamento que tentava combinar modelos 
teóricos diferenciados de maneira criativa e dotou à chamada teoria dos discursos sociais de uma essencialidade logocêntrica, redutora, que perde o conjunto teórico necessário para problematizar os processos de comunicação social (VERÓN, 1981). 


\subsection{INDÚSTRIA CULTURAL}

Indústria cultural é o nome genérico que se dá ao conjunto de empresas e instituições cuja principal atividade econômica é a produção de cultura, com fins lucrativos e mercantis. No sistema de produção cultural encaixam-se a TV, o rádio, jornais, revistas, entretenimento em geral; que são elaborados de forma a aumentar o consumo, modificar hábitos, educar, informar, podendo pretender ainda, em alguns casos, ter a capacidade de atingir a sociedade como um todo.

Informações da Organização Mundial do Comércio (OMC) dão conta de que o faturamento das indústrias criativas no mercado internacional duplicou nos primeiros três anos do século XXI. Segundo os cálculos dos especialistas da Organização das Nações Unidas (ONU), a economia criativa, que envolve setores tão díspares como o teatro, o artesanato, a televisão, o cinema, a publicidade e desenvolvimento de programas de computador, entre muitos outros, é responsável, hoje, por 7\% das riquezas produzidas no mundo (o produto Interno Bruto, ou PIB) e, como cresce rapidamente, logo chegará aos 10\%. Essa, no entanto, é uma média estatística, e esconde disparidades terríveis, que não podem ser ignoradas (A UNESCO E A CULTURA DO BRASIL, 2005).

A Declaração Universal sobre a Diversidade Cultural da Unesco, de 2002 afirma:

Frente às mudanças econômicas e tecnológicas atuais, que abrem vastas perspectivas para a criação e a inovação, devese prestar particular atenção à diversidade da oferta criativa, ao justo reconhecimento dos direitos dos autores e artistas, assim como ao caráter específico dos bens e serviços culturais (A UNESCO E A CULTURA DO BRASIL, 2005).

\subsubsection{Indústria Cultural no Brasil}

A indústria cultural no Brasil, não apresenta homogeneidade, pois existe uma grande diferença entre as classes sociais. A desigualdade na divisão de renda, impossibilita a existência de uma sociedade de consumo consistente. 
A definição de cultura: referem-se aos componentes simbólicos e aprendidos do comportamento humano, tais como a língua, a religião, os hábitos de vida, e as convenções. Sendo o oposto do instinto, é muitas vezes considerada como aquilo que distingue o homem do animal. No âmbito desta perspectiva, a cultura, que apenas o Homem possui, corresponde ao desenvolvimento intelectual e a um refinamento de atitudes (PIRES, 2004, p. 35).

\subsubsection{Cultura de Massa e Cultura}

Popular

Comunicação de Massa é a comunicação dirigida a um público de massas, heterogêneo e anônimo, por intermediários técnicos e a partir de uma fonte organizada, geralmente ampla e complexa (BELTRÃO, 1986). A caracterização dessa fonte - sistema, organização, instituição ou indivíduo do qual provém a mensagem - é importante para delimitar as fronteiras que separam a comunicação de massa da que não é de massa.

Apesar da comunicação autêntica ser a que se assenta sobre um esquema de relações simétricas numa paridade de condições entre emissor e receptor, na possibilidade de ouvir o outro e ser ouvido, como possibilidade mútua de entendimento, os meios de comunicação de massa são veículos, sistemas de comunicação num único sentido (mesmo que disponham de vários feedbacks, como índices de consumo, ou de audiência, cartas dos leitores). Esta característica distingue-os da comunicação pessoal, na qual o comunicador conta com imediato e contínuo feedback da audiência, intencional ou não, e leva alguns teóricos da mídia a afirmar que aquilo que obtemos mediante os meios de comunicação de massa não é comunicação, pois esta é via de dois sentidos e, portanto, tais meios deveríam ser denominados veículos de massa (Idem).

O termo Comunicação de Massa (Idem) apresenta diversas definições: uma é que se trata de qualquer emissão, recepção ou afluência de conteúdo informativo, síncrona ou assíncrona, feita de um ou vários emissores para diversos (mais de um) receptores, de forma tal que torna inviável a avaliação pormenorizada do fenômeno, a não ser com meios de ordem quantitativa (pesquisas) ou qualitativa (pesquisas de feedback). 
Podendo ter diversas interpretações e significados, se referindo às mensagens transmitidas para a massa pelos meios de informação, também através dos indivíduos que englobam essa comunicação social. Ou seja, um sistema produtivo que visa gerar e consumir idéias para diversos objetivos e públicos. A divulgação em grande escala de mensagens, a rapidez com que elas são absorvidas, a amplitude que atingem todo tipo de público, cuja própria sociedade através da Indústria Cultural criou e se alimenta, gera um enorme interesse e abre espaço para o estudo de nosso comportamento. Como conseqüência das tecnologias de comunicação aparecidas no século $X X$, e das circunstâncias geopolíticas configuradas na mesma época, a cultura de massa desenvolveu-se a ponto de ofuscar os outros tipos de cultura anteriores e alternativos a ela. Antes de haver cinema, rádio e TV, falava-se em cultura popular, em oposição à cultura erudita das classes aristocráticas. Em cultura nacional, componente da identidade de um povo; em cultura clássica, conjunto historicamente definido de valores estéticos e morais; e num número tal de culturas que, juntas e interagindo, formavam identidades diferenciadas das populações (BORDENAVE, 1977).

A chegada da cultura de massa (CAPARELLI, 1980), porém, acaba submetendo as demais "culturas" a um projeto comum e homogêneo. Por ser produto de uma indústria de porte internacional (e, mais tarde, global), a cultura elaborada pelos vários veículos esteve sempre ligada intrinsecamente ao poder econômico do capital industrial e financeiro. A massificação cultural, para melhor servir esse capital, requereu a repressão às demais formas de cultura - de forma que os valores apreciados passassem a ser apenas os compartilhados pela massa (COSTA, 2002).

A cultura popular, produzida fora de contextos institucionalizados ou mercantis, teve de ser um dos objetos dessa repressão imperiosa. Justamente por ser anterior, o popular era também alternativo à cultura de massa, que por sua vez pressupunha - originalmente - ser hegemônica como condição essencial de existência.

O que a indústria cultural percebeu mais tarde (e Adorno constatou, pessimista), é que ela possuía a capacidade de absorver em si os 
antagonismos e propostas críticas, em vez de combatê-lo. Desta forma, sim, a cultura de massa alcançaria a hegemonia: elevando ao seu próprio nível de difusão e exaustão qualquer manifestação cultural, e assim tornando-a efemêra e desvalorizada (HORKHEIMER; ADORNO. In: LIMA, 2000).

A "censura", que antes era externa ao processo de produção dos bens culturais, passa a estar no berço dessa produção. A cultura popular, em vez de ser recriminada por ser "de mau gosto" ou "de baixa qualidade" , é deixada de lado quando usado o argumento mercadológico do "isto não vende mais" - depois de ser repetida até exaurir-se de qualquer significado ideológico ou político.

No contexto da indústria cultural - da qual a mídia é o maior portavoz - são totalmente distintos e independentes os conceitos de "popular" e "popularizado", já que o grau de difusão de um bem cultural não depende mais de sua classe de origem para ser aceito por outra. A grande alteração da cultura de massa foi transformar todos em consumidores que, dentro da lógica iluminista, são iguais e livres para consumir os produtos que desejarem. Dessa forma, pode haver o "popular" (i.e., produto de expressão genuína da cultura popular) que não seja popularizado ("que não venda bem", na indústria cultural) e o "popularizado" que não seja popular (vende bem, mas é de origem elitista) (COSTA, 2002). 


\subsection{SUJEITO CONTEMPORÂNEO}

Aparentemente a criação da individualidade e da coletividade apresenta-se em alta, pois tudo leva a crer que exista um trabalho para referenciar comunidades que partilham de estilos de vidas, gostos, hábitos. A figura moderna da subjetividade, com sua crença na estabilidade e sua referência identitária, agonizante desde o final do século passado, estaria chegando ao fim?

A globalização que intensifica a personalização e a individualidade produz pacotes de perfis, estilos e formas de atuação, prontos para serem consumidos pelas subjetividades independente do contexto geográfico, econômico ou social.

\footnotetext{
Identidades locais fixas desaparecem para dar lugar a identidades globalizadas flexíveis, que mudam ao sabor dos movimentos de mercado e com igual velocidade (LINS. In: ROLNIK, 2002).
}

As mudanças implicam na conquista de adaptabilidade de um mundo novo, seguindo os preceitos do mercado, adequando-se à lógica dos lançamentos de produtos, serviços, idéias, comportamentos etc.

Estabelece-se um paradoxo: de um lado, a persistência da referência identitária e do outro a configuração do papel pessoal exigido e esperado para a adequação do perfil do mercado.

Na visão de Rolnik (2002), as subjetividades são tomadas pelo sentimento de fracasso e despersonalização. As forças que deveriam ser motivadoras desestabilizam. Para impedir a perda da identidade interrompe-se o processo anestesiando a vibração corporal e os afetos. Paralelamente, o mercado apresenta drogas que sustenta e produz a demanda de ilusão. São caracterizadas como drogas: (a) produtos do narcotráfico, pílulas biológicas e vitaminas; (b) as drogas oferecidas pela TV nos estereótipos de perfeição e felicidade; (c) a droga da literatura de auto-ajuda e esotérica; (d) as drogas ligth e diet prometendo o modelo padrão de beleza.

Atualmente existem duas frentes em relação às subjetividades: 0 grupo que luta contra a globalização da identidade para proporcionar lugar aos 
processos de singularização, criação existencial movidos pelas forças dos acontecimentos; e a desestabilização levada ao extremo que traz ameaça de descontrole de forças promovendo o caos psíquico, moral, social e orgânico.

O sujeito contemporâneo poderá usufruir da riqueza do momento atual dependendo da forma que as subjetividades enfrentam os vazios provocados pelas figuras que surgem a cada momento, produzindo a partir daí, idéias e possibilidades de vida.

Atualmente o mundo é percebido como fragmentado, complexo e imprevisível. Na Pós-modernidade as visões de mundo foram desconstruídas e, o conhecimento pós-moderno é composto de "pequenos relatos", de narrativas múltiplas sobre um mundo também múltiplo. As transformações na produção contemporânea de conhecimento devem ser entendidas como o marco da institucionalização da informática. O acesso fácil e rápido à informação dissolveu o "grande discurso científico" da Modernidade, rompendo também "a trama enciclopédica na qual cada ciência devia encontrar seu lugar" (LYOTARD, 1979, p. 71).

Dando continuidade aos estudos de Lyotard, Vattimo enfatiza a necessidade de desconstruir o modelo moderno de ciência universal, considerando o conhecimento pós-moderno um conjunto de pequenos relatos sobre o mundo. De acordo com a visão do autor os conceitos modernos apresentam-se ineficazes para a análise do que ocorre na Pós-modernidade, reflete uma tentativa inócua de restabelecer a tranqüilidade e a ordem que a ciência moderna propiciava. Para ele, a dificuldade de lidar com a ruptura e de apreender as características próprias do viver contemporâneo cria, com freqüência, uma visão de que todos os fenômenos atuais são negativos e destruidores de tudo que tínhamos de positivo no mundo. Essa negatividade impede, no entanto, que uma nova ordem - diferente, mas não menos humana do que a da Modernidade - seja percebida. Também considera as tecnologias da informação a base para o rompimento com a produção moderna de conhecimento (VATTIMO, 1985, p. 18). 
informação, seria possível realizar uma 'história universal', precisamente essa história se tornou impossível" (Idem, p. 11).

Outros teóricos da Pós-modernidade se reapropriam de conceitos modernos para pensar o mundo atual, em oposição a Lyotard e a Vattimo, interpretam os fenômenos pós-modernos através das modernas idéias do marxismo.

Destacando grande importância às condições de produção da ordem capitalista, as teorias pós-modernas sob a influencia do marxismo criticam as concepções sobre a fragmentação do mundo pós-moderno apresentadas. Do ponto de vista de Harvey (1989), Jameson (1991) e Bauman (1997), a complexidade e a fragmentação pós-modernas, paradoxalmente, não excluem uma historicidade e uma lógica global de compreensão. Concordam com as concepções de Lyotard e de Vattimo sobre uma ruptura histórica entre Modernidade e Pós-modernidade. Diferentemente destes, no entanto, Jameson, Harvey e Bauman buscam construir categorias globais para dar sentido à época pós-moderna. Para tanto, enfatizam o modo de produção capitalista como principal categoria de análise, relegando a segundo plano as condições pós-modernas de produção de conhecimento. Nessa visão, a ancoragem da Pós-modernidade é um conjunto de alterações objetivas na ordem econômica do capital.

$\mathrm{Na}$ contemporaneidade, não vigora mais a lógica da produção industrial e a conseqüente divisão entre classes produtoras e trabalhadoras. A esfera econômica se expandiu para todos os níveis do viver humano, inclusive para a esfera cultural. A lógica da Pós-modernidade é aquilo que Jameson (1991) chama de lógica cultural do capitalismo tardio. A esfera cultural torna-se coextensiva à economia. Essa expansão capitalista estruturou nossa sociedade em torno do consumo de bens materiais, de informação e de cultura.

A posição de Jameson frente à tecnologia relaciona-se também à expansão capitalista e à organização da sociedade a partir do consumo. Segundo ele, o desenvolvimento tecnológico, na concepção marxista, é resultado do desenvolvimento do capital. O desenvolvimento econômico pósguerra foi o fator que gerou a expansão tecnológica de sistemas aperfeiçoados 
de automação da produção e da distribuição. Esse quadro, por sua vez, propiciou a intensificação da produção em massa, uma distribuição mais rápida dessa produção e a circulação veloz do capital resultante de suas vendas.

Harvey (1989) discute a Pós-modernidade sobre a expansão do capitalismo e sobre a sociedade de consumo. Segundo ele, o sistema de produção contemporâneo não é mais, como acontecia na Modernidade, racional, uniforme e padronizado. Na época moderna, cada espaço era destinado à realização de uma tarefa e cada trabalhador especializava-se em uma das etapas produtivas. Ao final do processo, um mesmo produto era produzido em série, de modo rigorosamente uniforme. Já no sistema pósmoderno, o trabalhador desempenha tarefas múltiplas e pouco demarcadas. A produção é flexível e voltada para a personalização de bens e serviços. Em um mesmo espaço, são produzidos em escalas industriais diferentes produtos personalizados. A distribuição desses produtos é mais rápida e a circulação do capital resultante de suas vendas veloz. A lógica pós-moderna de produção é, portanto, flexível, ágil e passível de constantes modificações. Todos esses fatores contribuem segundo sua análise, para o aumento do consumo a níveis inesgotáveis e para a organização de nossa sociedade em torno desse consumo.

Bauman (1997) é o que mais se detém na categoria consumo. Esta é por ele considerada como fator de referência e de organização da sociedade pós-moderna. Afirma que todas as sociedades sempre consumiram, mas aquilo que caracteriza a sociedade contemporânea como sociedade de consumo é a ênfase dada a esse consumo. Os membros da sociedade moderna definiam suas redes de sociabilidade em torno da capacidade de produção. Já na Pós-modernidade, a organização social se dá mais pela capacidade e pelo desejo de consumir do que pelo que cada um de seus membros produz.

Segundo o autor, a conexão de computadores através da Internet intensificou a possibilidade de consumir e deslocou sua ênfase dos bens materiais para a informação. Grande quantidade de informação é consumida instantaneamente e a custos baixos, independentemente do local onde é 
gerada ou recebida. Tudo isso cria, de seu ponto de vista, novas formas de exclusão social:

A elogiadíssima "interatividade" do novo veículo é um grande exagero; deveriam antes falar num "meio interativo one-way". Ao contrário do que costumam acreditar os acadêmicos, eles próprios integrantes da nova elite global, a Internet e a Web não são para qualquer um, e é improvável que jamais venham a se abrir para o uso universal (BAUMAN, 1998, p. 60-61).

O principal ponto de vista em relação às novas tecnologias da informação presente na obra de Bauman, e também nas de Harvey e Jameson, apresenta a sociedade estratificada de modo dualista em função do acesso às novas tecnologias digitais, onde uma minoria detém a informação, e o restante da população é excluído do amplo consumo da mesma.

A discordância entre os filósofos é que Lyotard e Vattimo afirmam que o amplo acesso à informação pode gerar visões múltiplas e relativizadas dos fenômenos mundiais, e às questões de exclusão social. Já para Harvey, Jameson e Bauman, o acesso à informação é gerador de exclusão e de intolerância nas relações sociais.

A despeito de divergências significativas entre esses dois grupos de teóricos pós-modernos, há em comum entre eles o pressuposto de uma ruptura histórica entre a Modernidade e a Pós-modernidade. 


\subsection{O PROBLEMA DO TEXTO}

Bakhtin, um dos maiores pensadores do século XX e um teórico fundamental da língua. Enfatizou a complexidade multiforme das manifestações de linguagem em situações sociais concretas, diferentemente de Saussure e dos estruturalistas, que privilegiam o sistema abstrato da língua, com suas características formais passíveis de serem repetidas. Bakhtin concebe a linguagem não apenas como sistema abstrato, mas também como uma criação coletiva, que integra diálogos entre muitos "eus" e muitos "outros". Para Bakhtin, o ato de fala, ou exatamente, o seu produto, a enunciação, não pode ser considerado levando-se somente em consideração as condições psicofisiológicas do sujeito falante - apesar de não poder de prescindir. A enunciação é de natureza social e para compreendê-la é necessário entender que ela acontece sempre numa interação. A verdadeira substância da língua é constituída, "pelo fenômeno social da interação verbal, realizada por meio da enunciação ou das enunciações. A interação verbal constitui assim a realidade fundamental da língua" (BAKHTIN, 1992a, p. 123).

O caráter interativo da linguagem constitui a base do corpus teórico bakhtiniano. A linguagem é compreendida a partir de sua natureza sócio-histórica. Segundo Bakhtin: "as palavras são tecidas a partir de uma multidão de fios ideológicos e servem de trama a todas as relações sociais em todos os domínios" (Idem, p. 41)

Ao delimitar a linguagem como objeto de estudo específico, há, na filosofia da linguagem e nas divisões correspondentes da lingüística geral, duas orientações principais: subjetivismo idealista e, objetivismo abstrato. A crítica epistemológica de Bakhtin considera que o subjetivismo idealista, ao reduzir a linguagem à enunciação monológica isolada, e o objetivismo abstrato, ao reduzir a linguagem a um sistema abstrato de formas, constituem um obstáculo a uma apreensão totalizante da linguagem. Para Bakhtin, a compreensão ampla da natureza da linguagem não está no meio dessas duas orientações; ela está além (BAKHTIN, 1992a).

Existe uma grande dificuldade em definir o caráter genérico do enunciado devido à heterogeneidade dos gêneros. É importante definir a 
diferença entre gênero de discurso primário - comunicação verbal espontânea, como linguagem de reuniões sociais, dos círculos, linguagem familiar, linguagem sociopolítica, filosófica, etc e, os gêneros de discursos secundários - o romance, o teatro, o discurso científico, o discurso ideológico - aparecem em uma comunicação cultural mais complexa e mais evoluída.

\begin{abstract}
Ignorar a natureza do enunciado e as particularidades de gênero que assinalam a variedade do discurso em qualquer área do estudo lingüístico leva ao formalismo e à abstração, desvirtua a historicidade do estudo, enfraquece o vínculo existente entre a língua e a vida. A língua penetra na vida através dos enunciados concretos que a realizam e é também através dos enunciados concretos que a vida penetra na língua (BAKHTIN, 1992, p. 282).
\end{abstract}

Sob o ângulo do enunciado, são considerados problemas da lingüística: a estilística, diretamente ligada ao enunciado, reflete a individualidade de quem fala ou escreve. O estilo está vinculado a unidades temáticas determinadas e a unidades composicionais - tipo de estruturação e de conclusão de um todo, tipo de relação entre o locutor e outros parceiros da comunicação verbal e a sua relação com o ouvinte, com o interlocutor, com o discurso do outro etc. Esse estudo deve partir do fato que os estilos da língua pertencem por natureza ao gênero e deve basear-se no estudo prévio dos gêneros e sua diversidade.

Tanto os estilos individuais como os que pertencem a língua tendem para os gêneros do discurso. A gramática se distingue da estilística, mas estão incorporadas dentro dos estudos. A gramática e a estilística se juntam e se separam em qualquer fato lingüístico concreto que, encarado do ponto de vista da língua, é um fato gramatical, e encarado do ponto de vista do enunciado individual, é um fato estilístico.

O diálogo é uma das formas mais importantes da interação verbal caracterizado não apenas como comunicação em voz alta, de pessoas face a face, mas toda comunicação verbal, de todo tipo. Qualquer enunciação constitui apenas a uma fração da corrente da comunicação verbal ininterrupta; que, por sua vez, constitui apenas um momento na evolução contínua e em todas as direções de um grupo social determinado. 
é vista a partir de uma perspectiva de totalidade, integrada à vida humana. A lingüística não pode dar conta de explicar um objeto multifacetado. Para explicar a dialogicidade, o aspecto lingüístico não é suficiente. Por isso, ele acrescenta o contextual e propõe assim uma disciplina, a metalingüística ou translingüística, para estudar o enunciado (BAKHTIN, 1992 a, p. 124).

A abordagem que Bakhtin propõe para o discurso - que ultrapassa os limites da lingüística - é a do estudo da própria enunciação. A estrutura da enunciação concreta é determinada inteiramente pelas relações sociais, ou seja, pela situação social mais imediata e pelo meio social mais amplo.

Para Bakhtin, a enunciação é produto da interação de dois indivíduos socialmente organizados e, mesmo que não haja um interlocutor real, este pode ser substituído por um representante ideal, mas que "não pode ultrapassar as fronteiras de uma classe e de uma época bem definidas (Idem, p. 112.)".

É a partir da concepção de linguagem de Bakhtin que nasce uma das categorias básicas de seu pensamento, que é o dialogismo. É a partir dela que ele estuda o discurso interior, o monólogo, a comunicação diária, os vários gêneros de discurso, a literatura e outras manifestações culturais. Ele aborda o dito dentro e como réplica do já-dito.

A palavra se orienta em função do interlocutor. Na realidade, a palavra comporta duas faces: procede de alguém e se dirige para alguém. Ela é o produto da interação do locutor e do interlocutor; ela serve de expressão a um em relação ao outro, em relação à coletividade. "A palavra é uma espécie de ponte lançada entre mim e os outros. Se ela se apóia sobre mim numa extremidade, na outra se apóia sobre o meu interlocutor. A palavra é o território comum do locutor e do interlocutor (Idem, p. 113)".

A filosofia do dialogismo consiste em olhar o mundo de um ponto de vista para melhor captar o movimento dos fenômenos em sua pluralidade e diversidade. Para Bakhtin, a atividade do diálogo e da criação do personagem no interior da literatura é modelar para o diálogo e a criação em todos os domínios da vida. O autor da obra literária, assim como o eu concebido por Bakhtin é uma entidade dinâmica em interação com outros eus e personagens. Dessa forma, o discurso não é individual tanto pelo fato de que ele se constrói entre, pelo menos, dois interlocutores que, por sua vez, são seres sociais; 
como pelo fato de que ele se constrói como um diálogo entre discursos, isto é, mantém relações com outros discursos. O discurso, para Bakhtin, é uma "construção híbrida", acabada por vozes em concorrência e sentidos em conflito.

As idéias de Bakhtin sobre o homem e a vida são caracterizadas pelo princípio dialógico. A alteridade marca o ser humano, pois o outro é imprescindível para sua constituição. Como afirma Bakhtin, a vida é dialógica por natureza. Assim, a dialogia é o confronto das entoações e dos sistemas de valores que posicionam as mais variadas visões de mundo dentro de um campo de visão:

\footnotetext{
"Na vida agimos assim, julgando-nos do ponto de vista dos outros, tentando compreender, levar em conta o que é transcendente à nossa própria consciência: assim levamos em conta o valor conferido ao nosso aspecto em função da impressão que ele pode causar em outrem [...] (BAKHTIN, 1992a, p. 35-36)".
}

A interação entre interlocutores é o princípio fundador da linguagem. É na relação entre sujeitos, ou seja, na produção e na interpretação dos textos que se constroem o sentido do texto, a significação das palavras e os próprios sujeitos. Com efeito, pode-se dizer que a intersubjetividade é anterior à subjetividade. Esta é o resultado da polifonia das muitas vozes sociais que cada indivíduo recebe, mas que tem a condição de reelaborar, pois como ensina Bakhtin, "o ser, refletido no signo, não apenas nele se reflete, mas também se refrata (Idem, p. 46)".

Esses aspectos do dialogismo interacional, contribuem para a compreensão, de características do discurso: os simulacros e as avaliações entre os sujeitos. A construção destas características é assentada naquilo que Bakhtin denomina horizonte ideológico, ou seja, na relação entre sujeitos (entre interlocutores que interagem) e a dos sujeitos com a sociedade.

Segundo Bakhtin, cada um de nós ocupa um lugar e um tempo específicos, e que cada um de nós é responsável ou "respondível" por nossas atividades. Estas ocorrem nas fronteiras entre o eu e o outro, e, portanto, a comunicação entre as pessoas tem uma importância fundamental. 
O dialogismo é o permanente diálogo entre os diversos discursos que configuram uma sociedade, uma comunidade, uma cultura. A linguagem é, portanto, essencialmente dialógica e complexa, pois nela se imprimem historicamente e pelo uso as relações dialógicas dos discursos. A palavra é sempre perpassada pela palavra do outro. Isso significa que o enunciador, ao construir seu discurso, leva em conta o discurso de outrem, que está sempre presente no seu.

\begin{abstract}
Para Bakhtin, "o enunciado sempre cria algo que, antes dele, não existira, algo novo e irreproduzível, algo que está sempre relacionado com um valor (a verdade, o bem, a beleza, etc.). Entretanto, qualquer coisa criada se cria sempre a partir de uma coisa que é dada (a língua, o fenômeno observado na realidade, o sentimento vivido, o próprio sujeito falante, o que é já concluído em sua visão do mundo, etc.). $O$ dado se transfigura no criado (BAKHTIN, 1992b, p. 348.)".
\end{abstract}

Para o teórico, é mais fácil estudar, no criado, o que é o dado: "toda análise científica se resume, na maioria das vezes, a descobrir o que já estava dado, já presente e pronto antes da obra [...]". É como se todo o dado se reconstruísse de novo no criado, se transfigurasse nele. Dessa forma, tudo é reduzido ao dado prévio, ao já pronto. O objeto vai edificando-se durante o processo criador, e o poeta também se cria, assim como sua visão do mundo e seus meios de expressão. As possibilidades e as perspectivas que estão presentes nas palavras e nas formas concebidas como abreviaturas ou representante de um enunciado, de uma visão do mundo, de um ponto de vista, etc. reais ou virtuais são infinitas (Idem, p. 349). 


\section{5 ANÁLISE DO DISCURSO}

A língua apresenta-se como um processo evolutivo. O sistema sincrônico - que ocorre em tempo real - não diz respeito a nenhuma fase distinta da evolução da língua. Só existe sob o ponto de vista da consciência subjetiva do locutor em determinada comunidade lingüística em um momento da história.

O locutor serve-se da língua para suas necessidades enunciativas concretas. Para ele, o centro da gravidade da língua não reside na conformidade à norma da forma utilizada, mas na nova significação que essa forma adquire no contexto (BAKHTIN, 2002, p. 92).

Sob o ponto de vista do locutor a forma lingüística tem sua importância enquanto signo variável e flexível. O receptor dá a mesma importância, onde o essencial é decodificar a mensagem e compreendê-la dentro do contexto do enunciado proposto.

\footnotetext{
Na prática viva da língua, a consciência lingüística do locutor e do receptor nada tem a ver com um sistema abstrato de formas normativas, mas apenas com a linguagem no sentido de conjunto dos contextos possíveis de uso de cada forma particular (Idem, p. 95).
}

No sentido prático a língua é inseparável do seu conteúdo ideológico. O sentido da palavra é totalmente determinado pelo seu contexto. Pode-se afirmar que toda enunciação apresenta um acordo ou desacordo com o contexto, em uma situação de interação ou conflito. A enunciação é um produto do ato da fala e não pode ser considerada individual e sim de natureza social (Idem, p. 109).

Expressão é tudo aquilo que tendo se formado e determinado de alguma maneira no psiquismo do indivíduo, exterioriza-se objetivamente para outrem com a ajuda de um código de signos exteriores (Idem, p. 111).

Todo aspecto da expressão/enunciação será determinado pela situação social imediata. A palavra constitui o produto de interação entre o locutor e o interlocutor. Através dela o sujeito posiciona-se em relação ao outro ou em relação à coletividade. O locutor é o dono da palavra. Considerando a 
materialização da palavra como signo, a sua própria realização na enunciação é determinada pelas relações sociais.

A situação social mais imediata e o meio social mais amplo determinam completamente e, por assim dizer, a partir do seu próprio interior, a estrutura da enunciação (BAKHTIN, 2002, p.113).

A situação e os participantes mais próximos determinam a forma e o estilo da enunciação. A consciência faz parte do ser, tem existência real. A ideologia do cotidiano representa a totalidade da atividade mental centrada no dia-a-dia do ser. De acordo com Bakthin, a obra estabelece vínculos com a consciência dos indivíduos receptores, e é interpretada dentro do espírito desse conteúdo e assim, recebe uma nova luz. Ela é levada a estabelecer contatos ideológicos ininterruptos dentro do cotidiano vivido, isso a faz significante.

A fundamentação da língua é constituída pela interação verbal. O diálogo é uma das interações mais importantes, que condiz não apenas com a comunicação face a face em voz alta entre dois seres, mas todo tipo de comunicação verbal. O livro, objeto de discussões ativas sob a forma de diálogo é considerado uma das formas de comunicação verbal. O discurso nele contido apresenta uma discussão ideológica sobre uma temática definida.

A análise do discurso, não aborda isoladamente a língua e a gramática, mas diz respeito ao discurso, que etimologicamente, significa a idéia de curso, de percurso, de correr por, de movimento. O discurso é assim palavra em movimento. Não se estuda a língua como sistema abstrato, e sim levantando os significados atribuídos pelos sujeitos que fazem parte de uma estrutura social.

São considerados no estudo da análise do discurso todos os processos e as condições de produção, pela análise da relação estabelecida pela língua com os sujeitos que a falam e as situações em que se produz o que dizem.

O discurso reflete sobre a maneira de como a linguagem está materializada na ideologia e como a ideologia se manifesta na língua. Nesse sentido, é possível complementar a relação entre a língua; o discurso e a 
ideologia com o fato de que não há discurso sem sujeito e não há sujeito sem ideologia (BAKHTIN, 2002, p.125).

O discurso não é fechado em si mesmo e nem é do domínio exclusivo do locutor: aquilo que se diz significa em relação ao que não se diz, ao lugar social do qual se diz, para quem se diz, em relação a outros discursos (BAKTIN, 1979).

$\mathrm{Na}$ análise do discurso busca-se interpretar e compreender a língua, como trabalho relevante do homem no seu tempo histórico. A linguagem serve para comunicar e para não comunicar, resultando no efeito de sentidos entre locutores. Ela não procura atravessar o texto para encontrar um sentido do outro lado, mas produz um conhecimento a partir do próprio texto, concebendo-o em sua discursividade.

As enunciações são unidades reais da cadeia verbal e estas não podem ser fragmentadas do contexto histórico das enunciações. A enunciação da comunicação verbal é realizada sob a análise do seu todo que é determinado pelos limites com outras enunciações. O problema do todo de uma enunciação é determinado pelo começo e final da mesma. O processo da fala e da atividade da linguagem é contínuo e ininterrupto sem apresentar início e final. As dimensões e a forma da enunciação são determinadas pela situação e pelo seu auditório, que obrigam o discurso interior a realizar uma expressão exterior definida, inserida no contexto não verbalizado da vida, ampliado pela ação, gesto ou proposta verbal da interação entre os participantes da enunciação. Como exemplo de enunciações cotidianas: a questão completa, o pedido, a ordem, a exclamação; todas exigem um complemento extra verbal assim como um início não verbal (BAKHTIN, 2002, p.125).

Outras dimensões deverão também ser consideradas, como aponta Maingueneau (1989): o quadro das instituições em que o discurso é produzido; os embates históricos e sociais, que se cristalizam nos discursos; e o espaço próprio que cada discurso configura para si mesmo no interior de um interdiscurso. Neste ponto, dois conceitos são de fundamental importância: o de ideologia e o de discurso. As duas grandes vertentes que vão influenciar a corrente francesa de análise do discurso são, do lado da ideologia, os conceitos de Althusser e, do lado do discurso, as idéias de Foucault. Identificase ideologia com a separação que se faz entre a produção das idéias e as 
condições sociais e históricas em que são produzidas. A ideologia a que eles se referem é especificamente a ideologia da classe dominante.

Para Althusser (1974), a classe dominante, para manter sua dominação, gera mecanismos de perpetuação ou de reprodução das condições materiais, ideológicas e políticas de exploração. É aí então que entra o papel do Estado que, por meio de seus aparelhos repressores, intervém ou pela repressão ou pela ideologia, tentando forçar a classe dominada a submeter-se às relações e condições de exploração. Para ele, a ideologia representa a relação imaginária de indivíduos com suas condições reais de existência.

Em Foucault (1997), os discursos são concebidos como uma dispersão, formados por elementos que não estão ligados por nenhum princípio de unidade. Para descrever essa dispersão, faz-se necessário buscar o estabelecimento de regras capazes de reger a formação dos discursos. Tais regras são por ele chamadas de "regras de formação", possibilitando a determinação dos elementos que compõem o discurso. São elas: os objetos que aparecem, coexistem e se transformam num "espaço comum" discursivo; os diferentes tipos de enunciação que podem permear o discurso; os conceitos em suas formas de aparecimento e transformação em um campo discursivo, relacionados em um sistema comum; os temas e teorias, isto é, o sistema de relações entre diversas estratégias capazes de dar conta de uma formação discursiva.

Em sua análise, Foucault rompe com a ordem clássica que via a história como um discurso do contínuo, do desenrolar previsível do mesmo. De acordo com Brandão (1994), ele instaura uma nova visão da história como ruptura e descontinuidade, permitindo o estabelecimento de diretrizes para uma análise do discurso. É de Foucault (1997) a afirmativa de que "em toda a sociedade a produção do discurso é ao mesmo tempo controlada, selecionada, organizada e redistribuída por certo número de procedimentos que têm por função esconjurar os seus poderes e perigos". A questão do interdito aparece, nesse contexto, como o procedimento de exclusão segundo o qual não se tem o direito de dizer tudo, de falar de tudo em qualquer circunstância. Enfim, diz ele, "não é qualquer um que pode falar de qualquer coisa". As instâncias de consagração do discurso, de legitimação e de reforço são institucionalizadas, atuando como uma espécie de pressão e com um poder de coerção. Grupos 
de procedimentos internos e externos existem para o controle e a delimitação do discurso. Dependendo de quem faz o discurso, ele resulta diferente. Dependendo das condições de seu funcionamento, da imposição de regras aos indivíduos que os pronunciam não se permitirá que todos tenham acesso a eles. Destaca Foucault que "a forma mais superficial e mais visível desses sistemas de restrição é constituída por aquilo que se pode agrupar sob o nome de ritual", que define a qualificação que deve possuir os indivíduos: a fala; os gestos; os comportamentos; as circunstâncias que devem acompanhar o discurso; como também o seu efeito sobre aqueles a que se dirigem.

Nessa espécie de discurso se incluem os discursos religiosos, judiciários, terapêuticos e, em parte, também os políticos.

Se forem consideradas as condições de produção em sentido estrito, incluem-se nelas as circunstâncias da enunciação, o contexto imediato. Se as consideradas em sentido amplo, as condições de produção incluem o contexto sócio-histórico e ideológico.

Foucault afirma ser o discurso de uma área específica de conhecimento caracterizado menos por um espaço de regularidades do que por um espaço de dispersão: dispersão de objetos, dispersão de temáticas, teorias, dispersão quanto às superfícies da qual o discurso emerge e de suas instâncias de delimitação. O que atribuiria uma suposta unidade a um discurso, afirma o autor, não seria a existência de um objeto único, de um estilo único, de temáticas e teorias ou conceitos hegemônicos. O que caracterizaria a unidade do discurso seria um jogo enorme de relações entre objetos, estilos, temáticas, teorias e conceitos. Caberia à análise do discurso descrever essa dispersão, buscando o estabelecimento de regras capazes de reger a formação dos discursos (BRANDÃO, 1994, p. 28).

A dispersão é normalmente analisada a partir de um universo composto, segundo um princípio de seleção e os resultados nem sempre são complementados pelos elementos excluídos dessas seleções, fato que pode redundar em conclusões incompletas ou mesmo equivocadas.

Para Orlandi (2000), as condições de produção do discurso compreendem fundamentalmente os sujeitos e a situação, além da memória. 
Pensada em relação ao discurso, a memória é tratada como interdiscurso, disponibilizando dizeres que afetam o modo como o sujeito significa em uma situação discursiva dada. É pelo funcionamento do interdiscurso que se suprime, por assim dizer, a exterioridade como tal, para inscrevê-la no interior da textualidade.

As condições de produção que constituem os discursos funcionam de acordo com certos fatores. Um deles é o que Orlandi (Idem) denomina "relação de sentidos", segundo a qual não há discurso que não se relacione com outros.

Um discurso aponta para outros que o sustentam, assim como para dizeres futuros. Não há começo absoluto nem ponto final para o discurso, ele tem relação com outros dizeres realizados, imaginados ou possíveis. Outro fator é a "relação de forças", ou seja, o lugar a partir do qual fala o sujeito e que é constitutivo do que ele diz.

Assim, as condições de produção do discurso implicam o que é material, o que é institucional e o mecanismo imaginário. Esses elementos irão contribuir para a constituição das condições em que o discurso se produz e, portanto, para a sua análise. Pode-se dizer, então, que o sentido não existe em si, mas é determinado pelas posições ideológicas colocadas em jogo no processo sócio-histórico em que as palavras são produzidas.

As palavras, expressões, proposições não existem em si mesmas, elas mudam de sentido segundo posições sustentadas por aqueles que as empregam, o que significa que o seu sentido é determinado pelas posições ideológicas colocadas em jogo no processo sócio-histórico em que elas são reproduzidas.

Desde que se pense em textos e na sua importância dentro de um esquema de funcionamento mais amplo que as relações intrínsecas existentes em seu interior, parece inevitável assumir uma perspectiva pragmática, que coloca em evidência o problema das condições de produção como quadro de informações prévio e necessário a uma observação interior de cada realidade discursiva.

O pressuposto defendido por Bakhtin segundo o qual cada texto (ou enunciado) teria um único autor - ou um grupo determinado de autores, no 
caso de trabalhos em colaboração, está sendo questionado por vários autores, dentre os quais se destaca Ducrot (1987), originando a teoria polifônica do discurso.

A polifonia no discurso parte do princípio de que não há textos puros e de que todo texto se relaciona com textos anteriores, seja em conformidade ou oposição. Ao seguir os padrões discursivos de se reportar os textos anteriormente escritos, o autor age em consonância com a comunidade científica, fazendo referências explícitas a outros textos. Essa relação é caracterizada pelo hábito de citação que Coracini considera uma manifestação da heterogeneidade mostrada, em nível explícito, não somente constituindo-se em um mecanismo de adesão a padrões discursivos vigentes em uma comunidade científica, mas também como artifício e estratégia de persuasão. Segundo ele:

[...] um texto qualquer resulta do entrecruzamento de uma série de outros textos, de outros autores, outros indivíduos, diferentes grupos ideológicos, enfim de diferentes discursos (CORACINI, 1991, p.148.).

As relações discursivas, segundo Foucault

(1997), caracterizariam não a língua que utiliza o discurso, não as circunstâncias em que ele se desenvolve, mas o próprio discurso enquanto prática. A tarefa do pesquisador de uma área específica como campo de conhecimento consiste em não mais tratar os discursos como conjuntos de signos - os elementos significantes que remetem a conteúdos ou representações - mas como práticas que formam sistematicamente os objetos de que falam.

Considerando os discursos, como prática, Foucault adota os princípios da pragmática semântica, campo em que são situadas as pesquisas de Oswald Ducrot e que caracteriza "aquilo que é feito pela fala", do que a fala faz, aquilo que condiciona a ação humana, uma ação realizada pela linguagem (DUCROT, 1987, p. 168).

Segundo Ducrot (Idem), um enunciado "é o produto da atividade do sujeito falante, quer dizer, um segmento do discurso"; um enunciado possui uma força ilocutória que atribui à enunciação um poder jurídico: o poder de 
obrigar a agir, no caso de uma promessa; de uma ordem, o de obrigar a falar, no caso da pergunta; o de tornar lícito o que não o era, o caso da permissão. Os efeitos da enunciação têm em si o poder de incitação do agir.

\begin{abstract}
"Interpretar uma produção lingüística consiste entre outras coisas, em reconhecer nela atos, e que este reconhecimento se faz atribuindo ao enunciado um sentido, que é o conjunto de indicações sobre o enunciado" [...] "o sentido é uma qualificação da enunciação e consiste notadamente em atribuir à enunciação certos poderes ou certas conseqüências (Idem, p. 168-9, 173.)".
\end{abstract}

Ducrot (Idem, p. 192) retoma também a teoria polifônica do discurso, afirmando, em contraposição à teoria da unicidade do sujeito falante, que várias vozes falam simultaneamente em um texto. Ainda relacionada à pragmática, pode-se evocar a imagem do teatro, dos papéis, destacando-se o autor, os personagens que ele cria e os atores, ou seja, os locutores. Como o enunciador não é responsável pelo material lingüístico utilizado, que é atribuído ao locutor, do mesmo modo não se vê atribuída à personagem de teatro a materialidade do texto, escrito pelo autor e lido pelos atores. Essa teoria dos papéis é evocada por Michel Foucault, em seus argumentos para a caracterização dos discursos de um campo específico do saber.

O conceito de papéis, que pressupõe o empréstimo de idéias, em um texto, bem como o poder dos discursos como práticas, respalda Foucault em seus conceitos de anonimato, das relações presentes no discurso, do poder conferido por essas relações (sistema de exclusão), da dificuldade de se atribuir autoria aos textos, de concordância, enfim, com um dos sentidos do processo de enunciação, também presente no pensamento de Ducrot, ou seja, o fato de a enunciação ser "uma atividade psicofisiológica implicada pela produção do enunciado, acrescentando-lhe eventualmente o jogo de influências sociais que a condiciona" (Idem, p. 168).

Bakthin (2002, p.128), define como o sentido da enunciação completa o seu tema. A significação unitária, uma propriedade que pertence a cada enunciação como um todo. O tema é concreto e se reporta ao instante histórico ao qual pertence. O tema da enunciação é definido pelas formas 
lingüísticas (palavras, sons, entonações etc) e pelos elementos não verbais da situação.

Faz parte também da enunciação a significação, que são os elementos abstratos da enunciação que são reiteráveis e idênticos sempre que repetidos. O tema é irredutível à análise. A significação do enunciado, por sua vez, pode ser analisada em um conjunto de significações ligadas aos elementos lingüísticos que a compõem.

O tema é um sistema de signos dinâmico e complexo, que procura adaptar-se adequadamente às condições de um dado momento da evolução. É uma reação da consciência em vir ao ser em devir. A significação é um aparato técnico para a realização do tema (Bakthin, 2002, p. 129).

Constituem auxiliares marginais das significações lingüísticas, os acentos apreciativos - determinados pela situação social imediata em cujo quadro se desenvolve a conversa e as entoações.

\begin{abstract}
Bakthin apresenta em ordem cronológica, as tendências possíveis da inter-relação dinâmica do discurso citado e do contexto narrativo: (a) Dogmatismo autoritário, caracterizado pelo estilo linear, impessoal e monumental de transmitir a fala de outrem na Idade Média; (b) Dogmatismo racionalista, com seu estilo linear ainda mais pronunciado nos séculos XVII e XVIII; (c) Individualismo realista e crítico, com seu estilo pictório e sua tendência para infiltrar o discurso citado com as réplicas e os comentários do autor, final do século XVIII e início do século XIX; (d) Individualismo relativista, com a sua diluição do contexto narrativo - época contemporânea (Idem, p. 153).
\end{abstract}

Procurando testar a característica da descontinuidade do discurso e, partindo de considerações sobre a impossibilidade de a linguagem científica ser impessoal e neutra, devido ao peso dos recursos subjetivos e argumentativos nela presentes, Coracini afirma, com base em suas pesquisas, utilizando-se de textos franceses e brasileiros na área das ciências biológicas, que, a despeito das aparências, o discurso científico é veiculado por uma linguagem altamente subjetiva, constituída de um fazer verdadeiramente persuasivo, também comprometido com intenções de dominação, por parte de seus enunciadores. A suposta opacidade do discurso nada mais seria que uma série de estratagemas para fazer crer que o discurso demonstrativo é neutro e objetivo (CORACINI, 1991). 
Além de ser argumentativo e de apresentar indícios de elementos de persuasão e intuição, o discurso científico serve-se de uma série de convenções partilhadas pela comunidade, ao mesmo tempo produtora e consumidora.

Aceitando-se a intersubjetividade como componente da atividade da produção e interpretação do discurso, aceitar-se-ia a existência de relações e contratos sociais na própria linguagem, concluindo-se que nenhum texto seria obra de um único indivíduo, mas do entrelaçamento de experiências e ideologias que pressupõem a presença ativa e efetiva do outro. 


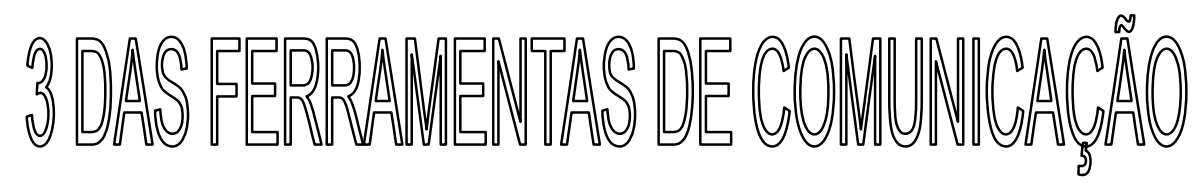




\subsection{PROPAGANDA}

A comunicação é definida por funções que se interagem em diversas proporções nas mensagens. As funções mais predominantes são a emotiva que define as relações entre a mensagem e o emissor; e a conativa que define as relações entre a mensagem e o receptor. Quem opera, produz ou reproduz os sistemas semióticos por meio de seus discursos, significações, informações; são os sujeitos da enunciação. Existe o sujeito da enunciação do nível da codificação (anunciantes, agências e veículos), e o sujeito da enunciação enquanto decodificação (público-alvo).

A instauração da significação é entendida como a relação entre o sujeito do discurso, os usuários dos sistemas semióticos e as funções metassemióticas atualizadas.

A propaganda constitui um fenômeno que chama a atenção de bilhões de pessoas localizadas ao redor do mundo. É criticada por pertencer ao mundo dos sonhos, da manipulação e do consumo, através da persuasão social e cultural.

Um dos efeitos da cultura global sobre a moda e a propaganda é o aumento do mercado de nichos, ou seja, o mercado apresenta-se cada vez mais segmentado, demandando esforço comunicacional diferenciado, utilizando novas formas estéticas para envolver o consumidor.

O desejo de chamar a atenção, agradar ou chocar faz parte do universo da arte e ajuda a publicidade a estruturar os seus caminhos estéticos, baseados nesses mesmos conceitos. Com o desenvolvimento do mercado, chamar a atenção do consumidor para provocar o enfeitiçamento através da mensagem exigiu da propaganda aprofundar-se em novas ferramentas, porém a imagem continua até hoje sendo um importante artifício para a sedução de públicos-alvos (IANN, 2003, p. 45).

Propaganda é a apresentação de vendas impessoais, estabelecidas em um nível predeterminado, visando a um público, dentro de um período especificado de tempo, paga por um patrocinador identificável. Conforme Costa e Talarico (1996, p. 57), uma propaganda possui quatro características: (a) uma 
mensagem verbal e/ ou visual; (b) um patrocinador identificado; (c) apresentação por um ou mais veículo de mídia; e (d) pagamento feito pelo patrocinador ao veículo que transmite a mensagem.

A importância da propaganda é comprovada pelo volume de dinheiro gasto com ela. As despesas com propaganda são, freqüentemente, expressas como uma porcentagem das vendas da empresa. A quantia gasta pela empresa em propaganda é mais influenciada por seus recursos e objetivos do que pelo que outras empresas do mesmo setor estão fazendo. A propaganda representa de $1 \%$ a $3 \%$ das vendas líquidas de muitas empresas, enquanto as despesas com recrutamento e operação de uma força de vendas são, normalmente, de $8 \%$ a $15 \%$ das vendas. No âmbito atacadista, os custos da propaganda são baixíssimos. Entretanto, as despesas com a venda pessoal podem ser de 10 a 15 vezes maiores do que os gastos com a propaganda. Entre os varejistas, incluindo as operações de self-service, o custo total dos funcionários que fazem contato com o cliente é substancialmente mais alto que o que é gasto com propaganda. A propaganda é um fenômeno da era industrial, apesar de sempre ter existido, com início na época das trocas que, provavelmente, vinham acompanhadas por informações sobre o objeto oferecido (KOTLER, 2000).

Todos os dias são lançados inúmeros produtos no mercado, porém não basta somente lançá-los, é necessário motivar o comprador, despertar seus desejos latentes. Praticamente, todos os produtos atuais surgiram de necessidades latentes. Por exemplo: não havia o desejo de se ter uma geladeira, mas havia a vontade de conservar os alimentos e manter as bebidas geladas.

Essas necessidades não são criadas pela propaganda, mas sim despertadas por ela. Lançar no mercado um produto sem propaganda é mandá-lo ao fracasso. É, por isso, um encontro de duas vontades: à vontade do fabricante/vendedor e a vontade do mercado.

A propaganda é um serviço que se compra, portanto, se paga. É um investimento. Por incrível que pareça, muitos clientes pedem uma campanha de propaganda sem determinar a verba de que dispõem. Estabelecer, previamente, a verba de propaganda é um elemento muito importante. Essa prévia análise da verba disponível deve ser feita a partir de 
alguns fatores, como: os recursos da empresa; as possibilidades do mercado; a potencialidade de vendas do produto; os objetivos que pretende alcançar no mercado. Foi desenvolvido, portanto, a divisão de trabalho, que incide sobre o uso específico da propaganda, dependendo do setor da economia que a está utilizando, da empresa ou da instituição, seu modo de organização e administração, do momento em que se está levando o efeito, o esforço publicitário e dos objetivos que devem ser atingidos.

De acordo com Cabral (1991, p. 43-44), a propaganda classificase em onze tipos descritos abaixo.

> Propaganda ao consumidor e business-to-business: os varejistas vendem apenas aos consumidores. $O$ editor da revista Veja precisa definir que parcela do seu orçamento será usada para atrair empresas a anunciarem na revista e quanto será destinado a vender seus exemplares.

Propaganda de produto: enfoca um determinado produto ou marca, seu objetivo é vender um produto específico. É subdividida em propaganda de produto de ação direta ou indireta. $\mathrm{A}$ ação direta busca uma resposta rápida. Por exemplo, um anúncio em uma revista, incluindo um cupom, ou um número 0800, pode levar o leitor a responder imediatamente. A ação indireta é projetada para estimular a demanda ao longo de um período de tempo maior. Ela pretende informar ou lembrar os consumidores de que o produto existe e assim ressaltar os seus benefícios.

A propaganda institucional: apresenta informações sobre a empresa do anunciante ou tenta criar uma atitude favorável em relação à empresa. Seu objetivo é vender a imagem da empresa.

Propaganda para demanda primária estimula a demanda por uma categoria genérica de produtos como café, 
sapatos de couro, malhas de puro algodão e Demanda Seletiva visa a estimular a demanda de marcas específicas. A propaganda Informativa: é usada quando o produto está na fase de introdução do seu ciclo de vida, com o objetivo de informar e não persuadir o mercado alvo. Durante os outros estágios do ciclo de vida do produto é considerada propaganda de sustentação da demanda.

A propaganda competitiva: impõe uma marca às restantes que existem no mercado. É utilizada quando o produto já passou do estágio de introdução do ciclo de vida e está competindo para uma participação no mercado com diversas marcas. Ela enfatiza as características e os benefícios específicos do produto, o seu diferencial.

A propaganda comparativa: faz referência a um ou mais concorrentes, onde o anunciante cita diretamente o nome do concorrente ou faz de maneira indireta, por meio de inferência, assinalando as diferenças entre as marcas concorrentes.

A propaganda promocional: diz respeito ao produto, mas já no sentido mais próximo da venda; ela promove os diferenciais do produto, os serviços mais eficientes e personalizados. Esta campanha parte do produto para a marca. Todas as campanhas de propaganda são de vendas, porém esta diz respeito à oferta, visa à venda imediata do produto. Ela é mais abrangente do que as outras, ligando-se a promoções, concursos, ofertas, procurando acelerar a rotação do produto no mercado.

> Campanha cooperativa: quando um revendedor e o fabricante se unem e dividem suas despesas para fazer uma oferta determinada de um ou vários produtos; são os anúncios de lojas. Há dois tipos: campanha cooperativa única, em que um fabricante e um revendedor se associam para vender produtos de uma marca; campanha cooperativa mista, em que um 
revendedor se associa aos vários fabricantes para ofertar diversos produtos não concorrentes entre si.

- Campanhas de varejo: são campanhas em que o lojista oferece seus produtos ao público. Esta é uma campanha simples, objetiva, direta e, excepcionalmente, informativa e útil. A base dessa campanha é a informação, que é transmitida de forma objetiva.

Campanhas especiais: assim chamadas porque não se incluem nas diferentes categorias. Visam a objetivos determinados: criar conceitos, formar tendências, vender idéias. Aqui dois tipos são destacados: campanhas de fundo social, que tem como exemplo a campanha pela vacinação; campanhas políticas, que podem ser as campanhas de candidatos a postos eletivos e as campanhas dos governantes.

Uma Campanha de Propaganda consiste em todas as atividades envolvidas, transformando um tema em um programa de propaganda coordenado, visando alcançar um objetivo específico para um produto ou marca. Para desenvolver uma campanha, é necessário definir objetivos, estabelecer um orçamento, criar uma mensagem, selecionar o veículo e avaliar a eficácia. O propósito da propaganda é vender um produto, serviço, pessoa ou lugar; no momento ou mais tarde. Esse fim é alcançado pela definição de objetivos, definidos por Boone e Kurtz (1995. p. 415-416) como: (a) apoio à venda pessoal; (b) melhorar as relações com revendedores; (c) introduzir novo produto; (d) expandir o uso do produto; e (e) evitar substituição.

Propaganda é um dos termos que destacamos arbitrariamente das fórmulas do latim pontificial empregado pela igreja ao tempo da ContraReforma (de propaganda fide), é mais ou menos reservado ao vocabulário eclesiástico até irromper na língua comum, no curso do século XX. A palavra que é definida como a propagação de princípios e teorias foi introduzida pelo Papa Clemente VII em 1597, quando fundou a Congregação da Propaganda, com o fito de propagar a fé católica pelo mundo. O significado da palavra, em inglês, quer dizer propagação de idéias políticas, para a propaganda comercial, 
o termo correto é advertising; em alemão significa idéias, e para o comercial usa-se Reklame. Nesse estudo utilizaremos o termo propaganda, ressaltandose que o corpus constitui-se preponderantemente de textos lingüísticos de caráter comercial, coletados de revistas, jornais e outdoors (SANT'ANNA, 1998, p. 75).

\begin{abstract}
A propaganda é uma tentativa de influenciar a opinião e a conduta da sociedade, de tal modo que as personagens adotem uma opinião e uma conduta determinada. A propaganda é a linguagem destinada à massa; ela emprega palavras ou outros símbolos veiculados pela televisão, pelo rádio, pela imprensa e pelo cinema. $O$ escopo do propagandista é o de influir na atitude das massas no tocante a pontos submetidos ao impacto da propaganda, objetos da opinião (SANT'ANNA, 1998, p. 46-47).
\end{abstract}

De acordo com Sant'Anna (1998, p173-174), a criação da Mensagem define que independente do objetivo de uma campanha de propaganda, cada anúncio deve alcançar dois objetivos: atrair e manter a atenção da audiência prevista e influenciar essa audiência na direção desejada. A mensagem possui dois elementos: (a) apelo, é a razão ou justificativa para ter uma crença ou comportamento. É o benefício que a pessoa receberá como conseqüência de aceitar a mensagem. Exemplo: dizer aos consumidores que um cereal por conter fibras (atributo), consumi-lo reduzirá a probabilidade de ter câncer (o benefício); e (b) execução é a combinação, de forma convincente e compatível, entre o atributo e o apelo. Simultaneamente à Criação da mensagem ocorre a Seleção de Mídia, o tipo geral, uma categoria determinada e o veículo específico. Essa escolha deve ser baseada nas características do veículo, que determinam a eficácia com que a mensagem é transmitida e a capacidade de atingir o público alvo.

Bussmann (1983) conceitua o papel propaganda igual ao da retórica que consiste na arte de persuadir, de convencer e de levar à ação por meio da palavra. O conjunto da propaganda é formado não apenas pelo texto lingüístico escrito ou falado, mas também pelo som, imagens (estáticas ou em movimento). A linguagem da propaganda distingue-se pela criatividade, pela diferenciação, pelo emprego de palavras que chamem a atenção do leitor, nem que para isso ela infrinja as convenções da gramática. 


\subsection{LINGUAGEM DA PROPAGANDA}

\subsubsection{Variação Lingüística}

Os textos utilizados nas mensagens de propaganda utilizam de recursos para atrair a atenção do receptor, chamar e prender a sua atenção e obter a sua simpatia. O código lingüístico como o português, não segue uma uniformidade e apresenta um feixe de variedades. A essa variação pode-se denominar diacrônica, que ocorre entre períodos mais longos; diatópica, no espaço geográfico conhecida como os dialetos; diastrática, variação entre diferentes camadas sociais; diafásica, são as variações entre as diferentes gerações que convivem; registro é a variação em um indivíduo que adapta sua fala ou escrita da língua ao contexto ou à situação, mais ou menos formal (coloquial), muito freqüente na linguagem da propaganda, o estilo adloquial, usado em eventos científicos com exigência à formalidade, e a gíria, que tem mais relação à variação diafásica ou diastrática (SANDMAN, 2001, p.49).

\subsubsection{Empréstimo Lingüístico}

Na linguagem da propaganda há muitos empréstimos lingüísticos viciosos, porque são empregados em lugar de termos vernáculos, sendo desnecessários porque não vem preencher lacuna, como no caso de se usar, por exemplo, grife no lugar de marca. Há também a influência de línguas estrangeiras, principalmente do inglês, a utilização de letras ou combinações de letras chamadas exóticas ou estranhas, por não fazerem parte do nosso sistema ortográfico comum. Explica-se a predileção pelo uso de letras ou combinações de letras exóticas com objetivos estilísticos ou comunicacionais especiais (Idem). Violar normas ortográficas é uma prática comum em nomes de produtos comerciais, em que o objetivos é prover o produto de uma simbologia gráfica distintiva (LEECH, 1966).

Exemplo: "Vip Express: a grife em transporte de móveis" (Espaço D, n. 9, 2004, p. 103-104 e 129).

\subsubsection{Aspectos Ortográficos}

Em textos técnicos a grafia predomina como um elemento neutro, isto é, não é usada como recurso de comunicação especial. Segue as normas 
ortográficas e impõe ao usuário a sua correta aplicação. Nos textos de propaganda comercial há um jogo com aspectos gráficos, com a função e valor das letras. Os textos mostram variações como o uso de letra maiúscula no meio da frase, troca de letras, jogo de sintagmas, união de aspecto gráfico com segmentabilidade de palavra etc.

\subsubsection{Aspectos Fonéticos}

Os recursos da estética da linguagem, que apresentam a função que se concentra na mensagem, realçando o significante do signo, fazendo com que ele seja menos indiferente, apagado, arbitrário ou neutro. O emissor visa chamar a atenção do receptor para o conteúdo da mensagem, despertar o prazer estético, obter a memorização da mensagem e levar ao consumo de um produto ou serviço. Serão abordados os esquemas fonológicos da rima, do ritmo, da aliteração e paronomásia.

A rima é a repetição de um som, de sílabas, pode estar no meio ou no final de verso, frase ou período. O ritmo é a sucessão regular de tempos fortes e fracos, ou sílabas fortes e fracas, muitas vezes, associado com a rima em textos de propaganda. Aliteração é a repetição de fonemas no início, meio ou fim de uma palavra. Exemplo "Para cada ambiente um estilo. Para cada estilo, uma solução" (Espaço D, n. 9, 2004, p. 150).

Jacobson (1971) define a paronomásia como a confrontação semântica de palavras similares do ponto de vista fônico, independentemente de toda conexão etimológica. Há o jogo com os sons, com a parte auditiva ou o significante do signo, para chamar e prender a atenção do receptor no referente ou conteúdo da mensagem, e levá-lo à ação de compra.

Aspectos Prosódicos são textos de propaganda que não contém signos apropriados para empregos enfáticos de palavras normalmente átonas. São textos escritos para serem lidos e não pronunciados.

\subsubsection{Aspectos Morfológicos}

A morfologia tem como objetivo o estudo das formas das línguas, do aspecto formal das palavras, suas flexões, seus sufixos e a diferença entre estes e aqueles, o tipo de estrutura das palavras: de subordinação ou coordenação de elementos; a classificação das palavras; os tipos de formação 
de palavras. Segue alguns exemplos de formação de palavras, utilizados pela propaganda pela formação criativa e caráter estilístico.

a) jogo com a palavra complexa - é a palavra formada por mais de um morfema lexical, composta ou derivada, com destaque ou utilizando na forma de jogo com o objetivo de prender a atenção do receptor. Exemplo: "Se você quer saber se a União Soviética vai virar Desunião Soviética, assine a Folha" (Folha, 3/2/90, p. C-7).

b) Prefixação - utilizado para realçar a excelência do produto ou serviço, usa-se além dos sufixos de grau, os prefixos chamados intensivos: "Ela é multidata, multimídia, multinoite, multieletrônica, Poupança Multidata Itaú." (Folha, 1/5/91, p.3 -3)

c) Sufixação - utilização de sufixos que indicam intensidade ou aumento como: super-, hiper-, mega-, multi-, extra-, ultra- etc; ou diminutivos, com a função emotiva de indicar apreço ou desapreço e a que objetiva obter o abrandamento de uma situação desagradável, ou ainda, sufixações incomuns. Exemplo: "Superpoupe. Tão seguro quanto a poupança e, no fim do mês, seu dinheiro gera muito mais dinheirinho." (Veja, n7; 22/2/2006; p. 6 e 7).

d) Cruzamento Vocabular - é a união de duas palavras para formar uma nova. Ex.: "Só existe uma coisa mais bonita que um sutiã Triumph. Outro sutiã Triumph. Triump, o showtiã (Desfile, setembro de 1990, p. 10)

e) Ressegmentação - são jogos criativos com uniddes lexicais mais longas ou complexas. Na ressegmentação, o prefixo re- como em remodelar, repensar, reconsiderar etc.

f) Desopacificação - quando modifica alguma palavra para se tornar mais transparente como "Bijóias. II Salão de Bijuterias e Jóias." (Marie Claire, maio de 1991, p. 63).

\subsubsection{Aspectos Sintáticos}

A sintaxe é a parte da gramática que estuda a disposição das palavras na frase e a das frases no discurso.

A sintaxe é a parte da gramática que estuda a combinação e função da palavra do sintagma. Deste na oração, bem como a 
combinação e função das orações, no período, quando este é composto (SANDMAN, 2001, p. 68).

Alguns aspectos sintáticos são característicos da linguagem da propaganda, como: simplicidade estrutural; topicalização; coordenação; paralelismo; simetria e combinações estilísticas. O aspecto da simplicidade estrutural diferencia os textos de propaganda, principalmente no apelo principal ou título do anúncio de propaganda, deixando elementos subtendidos apenas na análise do contexto. Dá-se o nome de topicalização quando o objeto direto não vem no seu lugar correto (depois do verbo), ganhando destaque ou ênfase. Coordenação normal ou não marcada é o aspecto percebido quando o texto apresenta séries mais longas de unidades coordenadas, é normal a conjunção vir apenas diante do último elemento. A ausência desse conectivo como a repetição excessiva de conectivos gera as figuras sintáticas do assíndeto e polissíndeto, respectivamente. Paralelismo é quando ocorre a repetição próxima da mesma estrutura sintática. Exemplo: "Sempre igual, sempre diferentes. Melissa." "Você leva a vida. A gente leva você." "Se você não quer perder mais negócios, não perca este. Vésper." "melhor que viver sonhando é sonhar vivendo" - forma um paralelismo, se considerar a seqüência que se repete infinitivo-gerúndio, aspecto mais superficial ou morfológico simplesmente (SANDMAN, 2001, p. 68; Idem, 1988).

Combinação estilística é um desvio da norma, apresentam uma força comunicativa visando prender a atenção do receptor da mensagem. Simetria é a figura em que os elementos se posicionam como em um espelho. Figura que consiste em repetir em uma frase, palavras da anterior, mas em ordem diversa e com acepções diferentes. Enquadra-se na função estética, concentrada no como a mensagem é apresentada, jogando os elementos do código, sendo que o objetivo é prender a atenção do receptor da mensagem (Idem). Ex.: "O que se leva da vida é a vida que se leva". "Agora tem 3. 32244000. Folha de São Paulo."

\subsubsection{Aspectos Semânticos}

O texto publicitário atinge o seu objetivo se contiver polissemia, se explorar a homonímia ou se contiver ambigüidades. O objetivo da duplicidade de sentido é chamar a atenção do destinatário, causar o 
estranhamento, obrigá-lo a refletir para entender a mensagem, prender sua atenção e levá-lo ao desejo e posterior ação de compra. Ex.: "Pode tirar a coroa. Uma rainha nunca perde a majestade. Bohemia a primeira e melhor cerveja do Brasil" (Veja, no7; 22/2/2006; p. 6 e 7).

Polissemia é a qualidade de uma palavra ter muitas significações (verde cor e fruta verde). Homonímia é a figura em que a um significante correspondem mais significados não aparentados (manga fruta e de camisa). Denotação é significado conceitual, fundamental e imutável de uma palavra. Conotação é o significado secundário ou subjacente que uma palavra possui, para além da acepção em que é empregada. Antonímia são palavras de significação oposta; qualidade e emprego de antônimos. Comum em textos de propaganda é comum a sua utilização como idéias opostas (SANDMAN, 2001, 78-80).

\subsubsection{Texto Publicitário}

A estrutura do texto publicitário compreende de headline, body copy e signature line, ou seja, título, texto e assinatura. No título, normalmente uma frase, nem sempre completa, interpela o destinatário apresentando-lhe algo. O texto entra em maiores detalhes a respeito do assunto tratado. $\mathrm{Na}$ assinatura o nome do produto ou serviço, e do fabricante; e a marca como a solução (Idem, p. 80).

\subsubsection{Figuras de Linguagem}

Figuras de linguagem são formas de expressão que fogem da linguagem comum, emprestando à mensagem maior vivacidade, vigor e criatividade. As mais comuns no texto publicitário são: a metáfora, a metonímia e a personificação.

A metáfora é o tropo em que a significação natural de uma palavra é substituída por outra, por virtude de relação de semelhança subentendida. A metonímia é a figura retórica de translação em que se aproveitam as conexões de sentido entre as palavras, por exemplo, tomando a causa pelo efeito, a matéria pelo objeto, o sinal pela coisa significada, a 
contigüidade, a associação espacial, histórica. A personificação é a forma ou realização pessoal de uma idéia ou de uma coisa abstrata (Idem, p. 85-86).

\subsubsection{Trocadilho}

Trocadilho é o gracejo resultante de um jogo de palavras, em que há equívoco no sentido ou no som - são palavras parecidas no som e diferentes no significado; é o uso de expressões ambíguas. Resulta de uma semelhança formal entre dois enunciados, por vezes, um deles elíptico, semelhança que pode chegar à identidade. Alguns trocadilhos relacionam uma paráfrase com seu parafraseado. Ex.: "Sem conserto do piano não há concerto". "O que você faz aqui? Nada. Slogan de uma escola de natação." "Dizer mais com menos". "Em vão os sonhos se vão". O efeito do trocadilho resulta da observação de duas formas semelhantes com sentidos relacionados de alguma forma. Há trocadilhos com intenção crítica, na qual se deseja transferir para um enunciado o suscitado pelo outro, geralmente da paráfrase para o parafraseado. Há ainda o caso do trocadilho em que o efeito resulta da relação que media os dois enunciados. Cacofonia é o trocadilho fonológico acidental e cômico em que o enunciado elíptico implícito, inesperado pelo emissor resulta no chulo, obsceno, no grotesco, etc (Idem, 2001, p. 91).

\subsubsection{Frase Feita}

Entende-se por frase feita a seqüência fixa menor ou maior de palavras, formando uma unidade sintática consagrada pelo uso. Utiliza-se em textos publicitários: a frase feita; a frase feita com pequenas alterações; a frase feita com reinterpretações; a frase feita com modificações que produzem mudança de sentido. Em todos os casos há a intenção de prender a atenção do destinatário da mensagem.

Frase Feita é a frase que consagrada pelo uso se lexicalizou. Ela se repete em contextos semelhantes sem alterações, exceto as de concordância sintática. Costuma ser exemplo de vivacidade popular na criação de ditos espirituosos. A linha que separa o clichê da frase feita é tênue, em certos casos. No discurso espontâneo, a eliminação do clichê é difícil, tão impregnada deles está a língua. O critério da supressão do desgastado pode 
ser perigoso, pois não consideram outros atributos de certos clichês como lirismo, humor, palpabilidade, atratividade, comunicabilidade, etc. Por outro lado, há clichês que são pedantes, de mau gosto, o que reforça a tese da eliminação. Exemplos: "Um exemplo vale mais que mil palavras. Uma única cena de televisão vale pelo mais longo e eloqüente sermão". "A boa propaganda é alma do negócio" (Idem, p. 93).

\title{
3.2.12 Lugar Comum
}

Textos desprovidos de criatividade, que visam causar o estranhamento. São expressões muito repetidas, chamadas de lugar comum, clichê, chavão. Exemplo: "Fogo de palha presentes. Toda mãe merece!" (Enfoque, n. 58, abril de 2006, p. 9).

\subsubsection{Associação de Palavras}

A associação de palavras consiste basicamente em escrever uma série de palavras a partir de uma palavra dada com a qual mantém algum tipo de relação. Pode ser uma atividade, sons, idéias, ou uma semelhança de sentidos, ou até uma relação subjetiva, como algum acontecimento da vida gravado na memória. A construção do texto publicitário abrange o campo das idéias e das palavras, e a sua associação.

\begin{abstract}
A associação de idéias consiste em uma forma de raciocínio em que uma idéia é ligada à outra. Para Aristóteles as idéias podiam ser associadas por semelhança e contigüidade. David Hume, no século dezoito, acrescentou a essa classificação a associação por causa e efeito (CARRASCOZA, 2003. p. 15).
\end{abstract}

A associação por semelhança leva os nossos pensamentos para o seu original. Indicam relação entre seres, coisas ou idéias que apresentam entre si elementos conformes. A associação por contigüidade indica proximidade, vizinhança, adjacência. A Associação de causa e efeito apresenta a conexão imediata ao fato que a gerou e as emoções e sentimentos que a acompanham no momento.

As relações e diferenças entre termos lingüísticos se desenvolvem em duas esferas distintas, cada uma das quais é 
geradora de certa ordem de valores; a oposição entre essas duas ordens faz compreender melhor a natureza de cada uma (SAUSSURE, 1995, p. 79-81).

As relações no discurso baseadas no caráter linear da língua, que excluem a possibilidade de pronunciar dois elementos ao mesmo tempo são chamadas de sintagmáticas. Fora do discurso, as relações nas quais as palavras que têm algo em comum se associam na memória e sua sede está no cérebro, são chamadas de paradigmáticas (CARRASCOZA, 2003. p.17).

\subsubsection{As correntes Espirituais e a Propaganda}

O tratamento da linguagem verbal encontrado nos textos das correntes espirituais fomenta $\mathrm{o}$ desenvolvimento interior longe das necessidades materiais, a mensagem da propaganda comercial se direciona para um mundo da aspiração do consumo possível e desejável.

Para que o discurso publicitário seja persuasivo e convença o seu público, precisa apresentar coerência. De acordo com Carrascoza (2003, p. 39), sustenta-se em quatro etapas: exórdio, introdução do assunto, visando captar o interesse do interlocutor; narração, apresentação dos fatos atribuindoIhes importância; provas, associadas aos fatos, devem ser demonstrativas, apresentando exemplos do passado, ressaltando o que deu certo ou não e peroração, que constitui o epílogo onde se unem os pontos principais das fases anteriores, apresentando quatro pontos: primeiro, busca predispor o interlocutor a favor; segundo, amplia ou atenua o que foi dito; terceiro, excita a paixão do interlocutor e o quarto, recapitula e coloca o interlocutor na posição de julgar.

\subsubsection{O minimalismo}

É um método de composição que tem como característica principal o uso obsedante da repetição, só alterada por pequenas modulações e mudanças pequenas ou rítmicas.

O slogan constitui um recurso retórico minimal utilizado para vitalizar a propaganda.

Slogan é um elemento pragmático de comunicação suasória, e resulta de um trabalho esmerado do emissor com a linguagem, objetivando obter memorização da mensagem de forma mais rápida e profunda por parte do destinatário (Idem, p. 56). 


\subsubsection{A Literatura}

A utilização de versos sempre foi uma característica da propaganda brasileira, e os autores literatos foram os primeiros a exibir o seu talento através dos versos para compor mensagens publicitárias.

Carrascoza (Idem, p. 65) cita Casimiro de Abreu como o primeiro poeta brasileiro a fazer anúncios. A contribuição dos escritores à linguagem publicitária foi de relevância. Nos últimos anos, os profissionais da área enriqueceram a bibliografia publicitária em função da importância no desenvolvimento da propaganda nacional.

\subsubsection{Plágio e a Coincidências na Propaganda}

O plágio consiste na apropriação consciente de idéias alheias. Coincidências ou igualdade de idéias. Normalmente, o plágio ocorre nos códigos lingüístico (título, texto e slogan - campo verbal), figurativo (fotos, ilustrações, logomarca, splashes, vinhetas etc) e morfológico (layout), onde o traço artístico é mais destacado (Idem). 


\subsection{GESTÃO DE MARCAS NA INDÚSTRIA DA MODA}

Há a necessidade de se fazer uma leitura e verificar se existem no mercado propostas teóricas e práticas para as empresas se adaptarem às mudanças solicitadas pelo mercado consumidor.

O adorno vem tendo há muito tempo um lugar na casa do poder. Desde o fim dos anos 60 e princípios dos anos 70, exemplo da relação entre a moda, a indumentária e o poder incluem a juventude. Esses jovens adaptavam sua moda e indumentária para tentar refletir os novos papéis entre os diferentes grupos sociais (BARNARD, 2003). As pessoas, principalmente os jovens, contestam através da estética, de sua aparência física pessoal e das mensagens dos produtos que optam para adquirir. Julgam importante a sua distinção e diferenciação dos outros. Portanto, as tentativas de mudanças nas relações de poder entre os indivíduos foram expressas ou refletidas em termos de moda e vestuário a partir dessa época.

A década de 60 foi uma época de muitas transformações no segmento de adolescentes; pelo fato de ter ocorrido mudanças sócioeconômicas que abalaram radicalmente o comportamento e atitude de uma forma geral, e em particular dos jovens. Eles passaram a expandir seu espaço na sociedade através de vários movimentos, surgindo assim o seu poder. Desta forma os anunciantes passaram a ficar mais atentos a esse novo segmento de mercado que estava surgindo de uma forma tão forte e marcante. Segundo Ogilvy as marcas eram relacionadas à modernidade, charme, inteligência, simpatia, elegância, tradição a tendências visionárias, da mesma forma que fazemos para qualificar uma pessoa (MARTINS, 1999).

$\mathrm{Na}$ década de $\mathbf{7 0}$ as marcas deixaram de ser apenas etiquetas aplicadas no interior das roupas e passaram a ser elemento de destaque na composição externa dos trajes. Não há dúvida sobre o fato de que o traje carrega uma retórica que põe à disposição das pessoas o sonho de mudar de identidade. Atrás de um pequeno detalhe, da cor de uma roupa, do corte, do volume, do tipo de tecido, de um adereço, milhares de 
pessoas procuram ser reconhecidas como "outras", realizando, de algum modo, o sonho de uma dupla personalidade (TORQUATO, 1991).

As roupas além de abrigar e preservar o pudor desempenham funções muito mais complexas, uma vez que através delas os indivíduos sinaliza ao mundo quem são ou como desejam ser reconhecidos pela sociedade. Os usuários procuram nos trajes transmitir mensagens, como por exemplo: o estilo de vida; a personalidade; a atratividade; a atitude com relação às questões sociais e até mesmo preferências pessoais. Através dele pode-se dizer quem se é e a que grupo social pertence ou se pretende pertencer, quais as atitudes em relação ao comportamento são adotadas e que partes da anatomia mais se valoriza (Idem).

O usuário dá à roupa um sentido especial. O significado da roupa pode ser considerado como sendo um produto das intenções de quem veste. De acordo com esse argumento, as crenças, esperanças e receios do usuário exprimem-se através do uso da roupa (WAJNMAN; ALMEIDA, 2002).

Atualmente as fusões não se fazem somente entre o corpo e os trajes, mas também entre o corpo e as marcas das roupas. Este objeto básico passa a ser objeto de desejo a partir do momento em que os profissionais de marketing agregam valor ao produto, estimulando o desejo do comprador, trabalhando as emoções dos consumidores com o intuito de aumentar a carga simbólica dos bens de consumo para que os produtos sejam valorizados perante os seus compradores.

As marcas são responsáveis por incorporarem personalidades e se propõem como possibilidades incorporáveis de personalidade de seu usuário; além disso, o seu uso é um meio pelo qual a necessidade do consumidor pode ser expressa. Os produtos desenvolvem através da estética da propaganda uma empatia com o público-alvo, onde terá a oportunidade de assumir a liderança de mercado conforme o resultado proporcionado pelo posicionamento executado através da campanha de propaganda valorizando a imagem projetada. As impressões e sensações causadas constituem a diferenciação com a 
concorrência. $O$ consumidor escolhe $o$ produto pela promessa do benefício oferecido. Torna-se fiel à marca quando compra seu atributo principal - a promessa de sua imagem, representando servilmente à imagem projetada deste ser na sociedade, como atração irresistível, criando envolvimento entre produtos e marcas.

Uma estratégia de estética utiliza estratégias
corporativas e de marketing como dados para expressar
a missão da empresa, objetivos de estratégias e cultura
através de meios visuais (e outros meios sensoriais). Se
implantada com sucesso, uma estratégia de estética cria
uma identidade para a organização e para suas marcas
(SCHMITT; SIMONSON, 2000, p. 40).

Os consumidores sentem um maior ou menor envolvimento com um produto, conforme a marca, que representa emoções que são fortalecidas na escala do egocentrismo. Logo, 0 alto ou baixo envolvimento do consumidor com a mesma depende de seu nível cultural e social, e depende ainda da quantidade de símbolos e imagens que projeta sensorialmente. Posicionar uma marca na mente das pessoas significa construir desejos que possam ser realizados pela compra da marca. Instigar e seduzir são pontos de fascínio que uma marca deve construir na mente das pessoas (COBRA; RIBEIRO, 2000; KRESS; VAN LEEUWEN, 1996).

A palavra marca tem origem germânica e significa aplicar um significado de identidade na propriedade. Significa um sinal distintivo de um objeto. Desenho ou etiqueta de produtos industriais. Representa a categoria ou qualidade. As pessoas associam a marca à experiência própria ou de outras pessoas. As marcas podem ser nomes fantasias, nomes de famílias ou pessoas. A marca suscita associação negativa ou positiva.

\footnotetext{
Marca é um símbolo identificador que distingue um produto ou companhia de seus concorrentes. Normalmente as marcas são registradas (trademarks) junto às autoridades regulatórias e, portanto passam a não poder mais ser livremente utilizada por outros (PYR MARCONDES E EDITORA MEIO E MENSAGEM, 2003, p. 18).
}

Marca é um nome, termo com função de identificar bens e serviços da concorrência, isto é, tudo que remeta a um produto ou um serviço. 
Uma marca é um nome diferenciado e/ou símbolo (...) destinado a identificar os bens ou serviços de um vendedor ou de um grupo de vendedores e a diferenciar esses bens e serviços daqueles concorrentes. Assim, uma marca sinaliza ao consumidor a origem do produto e protege tanto o consumidor quanto o fabricante, dos concorrentes que oferecem produtos que pareçam idênticos (AAKER; KUMAR; DAY, 1998, p. 7).

A marca, do ponto de vista do consumidor, constitui-se uma junção de fatos, sentimentos, atitudes, crenças e valores que se relacionam àquele nome e o diferencia do concorrente; "síntese das experiências reais e virtuais, objetivas e subjetivas" desse consumidor em relação a ela. Do ponto de vista da organização, é a "síntese da sua franquia" junto ao mercado. Esse valor é chamado de valor patrimonial da marca, que significa a percepção que todos têm, é a qualidade relativa dos produtos e/ou serviços, o seu desempenho financeiro, a fidelidade, a satisfação e a estima geral do consumidor em relação à mesma. É o maior patrimônio dentro de uma empresa (SAMPAIO, 2002, p. 25).

Marca não é uma coisa, um produto ou uma organização. Marcas não existem no mundo físico, são construções mentais. Marcas podem ser mais bem definidas como a soma total de experiências humanas, percepções e sentimentos sobre algo em particular, seja um produto ou uma organização. Mas existem no âmbito da consciência, seja dos indivíduos seja de um público (Idem, p.26).

As marcas apresentam seis níveis de significado: atributos físicos, representados por suas características físicas (durabilidade); benefícios, o que o cliente espera que o produto faça por ele, sobretudo para obter prêmios simbólicos pela posse da marca (status e prestígio); valores, o conceito de caro ou de barato que a marca representa; cultura, o conceito de cultura da marca se sobrepõe muitas vezes ao conceito de cultura do próprio consumidor; personalidade, as marcas manifestam personalidade e passam a quem as compra; usuário, o consumidor é caracterizado pela marca que usa (COBRA; RIBEIRO, 2000).

Imagem de marca é a impressão coletiva que as pessoas têm a respeito de uma marca de um produto ou serviço. Trata-se da informação positiva ou negativa que alguém adquiriu sobre uma marca em particular (GRACIOSO, 2004, p. 25). 
A difusão da imagem de marca pelos meios naturais, ou seja, através das experiências, seria muito lenta. Com o objetivo de acelerar esse processo surgiu a propaganda, aumentando a penetração das marcas dos produtos e serviços até as pessoas que não conheciam. A imagem da marca não é criada pela propaganda e sim, pelo cumprimento da promessa realizada por ela, por meio da satisfação, pelos seus atributos de qualidade adequados às necessidades do seu público-alvo.

Brand Equity significa valor da marca. Fundamenta-se em todo valor que é agregado a ela, desde os muros da empresa à qualidade percebida pelo consumidor. São os ativos e passivos ligados à marca.

Conforme Pinho (1996, p. 43), uma marca passa a significar não apenas um produto ou serviço, mas incorpora um conjunto de valores e atributos tangíveis e intangíveis relevantes para o consumidor e que contribuem para diferenciá-las daquelas que Ihe são similares. Assim, ao adquirir um produto, o consumidor não compra apenas um bem, mas todo o conjunto de valores e atributos da marca.

Os atributos da marca podem ser tangíveis (atributos funcionais, desempenho do produto, preço, garantia, embalagem, tecnologia) e intangíveis (ou emocionais, são atributos ligados à percepção que o consumidor tem em relação ao produto, como, por exemplo: masculinidade, entusiasmo, confiança, diversão, eficiência).

Para o cliente, a marca é um conglomerado de fatos, sentimentos, valores, atitudes e crenças que se relacionam com aquele conjunto de nomes e símbolos que o acompanham. Alguns têm sensações positivas em relação à marca, como, por exemplo: admiração; amizade e diversão. Gera valor tanto para o consumidor quanto para a empresa.

Brand equity significa esse valor que a marca possui. Está intimamente relacionado com a lealdade à marca, conhecimento do nome, qualidade percebida, associação à marca, e o diferencial sobre a marca. "Brand equity lida com o valor, normalmente é definido em termos econômicos, de uma marca, para além do patrimônio físico associado à sua fábrica ou fornecedor" Este valor está ligado com a totalidade de percepção da marca, 
incluindo qualidade relativa dos produtos e/ou serviços. O que sentem em relação à marca, todos os envolvidos com ela (BIEL, 1996, p. 45).

Conforme Aaker; Kumar e Day (1998) e Pinho (1996), brand equity está baseado em cinco categorias: lealdade à marca, conhecimento do nome de marca, qualidade percebida, associações da marca, ativos do proprietário da marca (patentes marcas registradas, relacionamento com os canais de distribuição).

As marcas conseguem obter identidade no mercado, que leva a possibilidade de geração de vendas e, que, na seqüência, cria uma situação de confiabilidade, a qual pode levar à efetivação das vendas e, seguida pela intimidade como grupo de consumidores, pode conduzir à repetição dessas vendas, o que desenvolve uma posição de valor efetivo para essa marca. Na evolução natural desse valor, a marca obtém fidelidade dos consumidores e, (...) atingem a condição de advocacia (SAMPAIO, 2002, p.57).

Brand Equity significa o valor que uma marca agrega ao produto ou serviço. Esse valor não é em relação ao seu desempenho funcional, mas sim, o está na cabeça dos consumidores.

Branding é o processo de desenvolver e manter a marca de forma estratégica e tática, com o objetivo de criar uma imagem única e positiva para o produto ou serviço. É uma filosofia de gestão, que conduz a marca como o ativo mais valioso da empresa e a razão da sua perenidade.

\subsubsection{As Marcas no Século XXI}

Grandes mudanças afetaram as características das marcas. A primeira apresenta a revolução na tecnologia de produção. Atualmente é muito difícil manter vantagens tecnológicas. As inovações e os processos desenvolvidos são copiados pelos concorrentes. As empresas que quiserem manter-se na vanguarda necessitam de evolução constante. A solução é inserir inovações nos sistemas de distribuição e vendas e garantir a individualidade da marca, através de conotações subjetivas como a confiança do consumidor. A segunda característica aborda a mudança no varejo. As grandes empresas perceberam que para receber o endosso de qualidade que valoriza a marca necessitavam estar presente nas grandes redes de varejo, que conquistaram a 
lealdade do consumidor e são os maiores anunciantes da mídia. A terceira característica é a comunicação com o mercado que extrapola os limites do anúncio e do comercial. Hoje a comunicação é o resultado de tudo o que a empresa faz e diz. Elas se comunicam até mesmo através de: política de responsabilidade social; comunicação dirigida; promoções no ponto de venda; eventos e feiras; shows; desfiles de moda; patrocínios de esportistas; veiculação de noticias com conteúdo editorial etc. A imagem da marca se confunde com a imagem institucional da empresa na cabeça do consumidor. A propaganda recebe atualmente, $30 \%$ das verbas de marketing, quando recebia até $70 \%$ há apenas quinze anos atrás. A distribuição dos investimentos em mídia e marketing no Brasil apresenta os seguintes resultados: eventos 13\%; CRM e business intelligence 6\%; mídia de massa 31\%; comunicação dirigida 14\%; Relações Públicas 7\%; trade marketing 11\%; campanhas de incentivo, premiações e concurso 10\%; programa de relacionamento 8\%. A quarta característica é a revolução da informação. As pessoas estão muito mais informadas e o ciclo vital de um produto é mais curto, exigindo o retorno mais rápido do investimento realizado. As condições do mercado mudam rapidamente e é preciso estar atento para acompanhar essas alterações. Os anunciantes devem aprender a comunicar-se com o público fora dos limites do anúncio e do comercial. A relação de fidelidade entre consumidores e marcas não existe mais. A quinta e última característica é que estamos na era dos serviços, que são bens intangíveis que se compram na base da confiança. Esse é o fator que contribui para a natureza subjetiva das marcas. A classe média gasta 2/3 do seu orçamento doméstico com serviços (GRACIOSO, 2004, p. 37-39).

As novas regras, com o cenário de empresas menos rentáveis que em períodos passados, transformou a gestão de marcas em algo que se situa hoje para além do marketing e da comunicação, indo se instaurar no âmbito da administração empresarial. A gestão das marcas hoje representa o aproveitamento de oportunidades, que podem promover a redução de custos, incremento de rentabilidade e fidelização do consumidor com o objetivo de se estabelecer a diferenciação e a garantia de resultados. 
Não é fácil criar uma grande marca. Requer liderança para persuadir o resto da empresa a seguir sua visão. Requer o senso artístico de proporção e tempo. Requer voluntariedade para distinguir você das marcas concorrentes. Também requer empatia com as pessoas que compram seu produto e com a humanidade de modo geral (D'ALESSANDRO; OWENS, 2002, p. XIX).

Alguns fatores contribuem com o sonho da imaginação como, por exemplo, a cultura de massa expressa na arte, na mídia e no lazer. Há também o fato de o consumo de marcas simbolizarem a realização e o poder que elas emprestam aos indivíduos e outros fatores são as novas tecnologias do mundo virtual. Enfim, todas essas fontes formam universos em que as pessoas projetam o que faz sentido a elas, como o poder da força e da sedução (Idem).

Em uma sociedade de consumo desenvolvida, todos os desejos, fantasias, projetos, paixões e exigências permitem à escolha e à aquisição de objetos. Necessidade e desejo são as duas entidades necessárias à passagem para 0 ato de consumo, sendo que as necessidades pertencem ao campo do real e os símbolos ao campo do imaginário. A necessidade precede o desejo e conduz à constituição da escala de preferências ou prioridades de cada indivíduo, às escolhas de consumo e aos atos de aquisição (ALLÈRÉS, 2000).

O consumo possui duas funções: satisfazer necessidades pessoais (respeitando uma ordem de preferência) e pertencer a um grupo, ou seja, situar-se socialmente. Esses dois níveis de atitude definem "estilos diferentes" que quando compreendidos são capazes de definir o que se passa entre um indivíduo e a sociedade, entre um consumidor e um produto, entre um cliente e uma loja, entre o passado de um indivíduo e seus sonhos, entre a tradição da sociedade e suas tendências às mudanças econômicas, tecnológicas ou sociológicas. Um dos objetivos da sociedade de consumo é o de criar e exacerbar, permanentemente, novas necessidades e novos desejos nos consumidores (Idem).

Os desejos, ao contrário das necessidades, dependem do domínio irracional, do sonho e das fantasias, ele é ilimitado. O desejo é, certamente, mais profundo que a necessidade, mas não é, de modo algum, mais essencial. A lógica da necessidade obedece à lógica da 
satisfação e a lógica do desejo, à lógica da falta; por isso que as pessoas não param de consumir, pois o desejo remete sempre para algo além do objeto de consumo, para uma negação da necessidade, ele remete para a falta, para a insatisfação, para a não-saciedade, portanto as pessoas, de uma forma geral, não param de consumir, assim como não param de desejar.

O efeito da propaganda atinge o público de imediato, lançando modas e estilos alterando o padrão e o consumo.

Segundo Guareshi (2000), o desejo, enquanto produtor de universos psicossociais pode ser entendido desdobrando-se em três movimentos: os de afetos (intensivo, inconsciente) enquanto intensidades em seu poder de atração e repulsa; um segundo movimento, onde os afetos buscam se exteriorizar, tomar corpo em matéria de expressão; como terceiro movimento, a formação de territórios existenciais (visível, consciente, aglomerado de diferentes matérias de expressão), onde os afetos podem se situar e se concretizar.

Sendo assim, viver é produzir mundos, produção de real, expressão de desejo no campo do social enquanto encontro de forças que se agenciam, de intensidades que se 'plugam' e se concretizam em acontecimentos. A propaganda utiliza a linguagem intensiva que estabelece uma "conexão direta" entre as instâncias psíquicas que definem o modo de se perceber e construir o mundo e aquilo que é produzido pelo capitalismo. A mídia passa a ser a própria linguagem, produtora de tipos de vida. É concebida com conceito, pois sem este ela não existe como função e não vende. Tem o compromisso de interferir no receptor, fazê-lo desejar, comprar e usar um produto (Idem).

Com o início do século vinte, normas e estilos foram quebrados influenciados pela tecnologia e pela sociedade capitalista. Como conseqüência dessa mudança, o mercado passou a orientar o que deve ou não ter uma identidade com o público. A partir deste mercado, cria-se moda.

Define-se como moda, movimentos cíclicos reconhecidos e aceitos por um público como referencial cultural e estético, por um período determinado de tempo (LIPOVETSKY, 1989. p. 24). 
A partir do momento que a moda passou a fazer parte do sistema industrial, foi incutido no seu sentido um processo manipulador da cultura.

As tendências da moda são orientadas, desde há muito tempo, pela tecnologia e pela relação do homem com o seu corpo e a sua mente.

O desejo é pura intensidade nômade à procura de uma linguagem, para que possa se expressar. Esta intensidade será captada pela mídia e investida de certo significado. As pessoas sentem que viver, ter prazer é possuir certo tipo de corpo, se vestir (ou despir) de um determinado jeito, amar e sorrir frente a determinados acontecimentos.

A ciência busca o homem perfeito nas pesquisas com o DNA humano, e a moda utiliza esse momento para elaborar suas criações, procurando sempre envolver o público com o ícone do momento (IAHN, 2003, p. 48).

As ferramentas de comunicação utilizadas pela moda para envolver e persuadir o público são a propaganda e a publicidade. O consumo de anúncios é maior do que o consumo de produtos. Nos anúncios vende-se estilo de vida, sensações, emoções, visões de mundo, relações humanas, sistemas de classificação, hierarquia em quantidades significativamente maiores que os bens adquiridos, como roupas, por exemplo. "Cada anúncio, à sua maneira, é a denúncia de uma carência da vida real (O PODEROSO MUNDO DOS ANÚNCIOS 16/06/03)".

A propaganda é modelo de referência desde as décadas de 20 e 30. Os publicitários procuravam guiar os indivíduos, ensinando-lhes, por meio de produtos, como se comportar. Os publicitários trabalhavam para a eficácia do mercado e o reforço da unidade nacional (ORTIZ, 2000).

Segundo Haug (1997), a publicidade trata seus destinatários como mercadorias, pois oferece a eles soluções para seus problemas de realização. Uma das maneiras da estética da mercadoria atingir as pessoas são as roupas anunciadas como embalagens como um meio para promover as vendas. Isto é, a propaganda oferece aos seus destinatários mercadorias para solucionar os problemas como, por exemplo, profissionais e amorosos. São elaboradas necessidades psicológicas, condicionamentos e mitos. 


\subsection{O PODER DA MÍDIA}

A pós-modernidade mudou o olhar, o sentir e o pensar do homem sobre a cultura e sobre a comunicação. Uma transformação que mexe, com a aplicação das ferramentas da Comunicação. Conceitualmente jornalismo e propaganda e publicidade são ferramentas distintas, que exercem diferentes funções sociais. O primeiro tem a função de informar eticamente e a propaganda e a publicidade tem funções de comunicar o produto e/ ou serviço e persuadir o público ao consumo do mesmo.

O momento atual é constituído pela hegemonia da imagem. As coisas valem pela sua representação, e não mais pela sua significação. O marketing impõe novos significados aos consumidores.

Para Baudrillard (2000), esta nova era instaurada pela imagem rompe todos os limites da farsa e falsificação. Na visão do filósofo francês, "nós já transgredimos tudo, inclusive os limites da cena e da verdade (...) Não haverá mais juízo final. Nós já fomos além dele". Baudrillard explica que o crescente poder da publicidade sobre a sociedade está estabelecido no que ele chama de a lógica do Papai Noel. Segundo ele, "as crianças não mais se perguntam sobre a existência do Papai Noel e não relacionam esta existência com os presentes que recebem como se tratasse de um jogo de causa e efeito. A crença no Papai Noel é uma fabulação racionalizante que permite preservar a relação miraculosa de gratificação pelos pais. Papai Noel não tem importância e a criança nele só acredita porque no fundo não tem importância. O que ela consome desta imagem, desta ficção, deste álibi - e em que acreditará mesmo quando deixar de crer - é o jogo da solicitude miraculosa dos pais e os cuidados que estes assumem em ser cúmplices da fábula. Os presentes apenas sancionam este compromisso. A operação publicitária age da mesma maneira. Nem o discurso retórico, nem mesmo o discurso informativo acerca das virtudes do produto, tem efeito decisivo sobre o comprador. Ele não acredita na publicidade mais do que a criança no Papai Noel. O que não o impede de aderir da mesma maneira a uma situação infantil interiorizada e de se comportar de acordo com ela". Para Baudrillard, o 
imperativo não passa de um álibi para a realização da operação na qual a própria publicidade transforma-se em mercadoria. A lógica dessa operação, que pode ser entendida como um mecanismo de ilusão cujo objetivo é garantir a crença em uma predeterminação dos papéis sociais. A figura do Papai Noel não desperta outro interesse a não ser por tornar-se álibi de uma manutenção recíproca da crença nos respectivos papéis propostos entre pais e filhos, os primeiros apresentando-se como retribuição dos desejos dos segundos. Da mesma maneira, a publicidade faz crer em uma sociedade de serviço extraordinário, a qual se colocaria a serviço dos desejos do consumidor.

A mídia percebida como um processo unificado, sob certa totalização, assume uma completa indistinção com o mercado. Essa concepção de um segundo tipo de consumo, resultante dessa configuração da cultura pós-moderna, lembra os estudos de Baudrillard sobre o funcionamento da publicidade, quando este afirma que, na sua maneira de operar, a publicidade apresenta-se como o "segundo produto de consumo e evidência de uma cultura (Idem)".

Baudrillard distingue duas funções da publicidade: uma função explícita, que ele chama o "imperativo" publicitário, e uma função implícita, denominada o "indicativo" da publicidade. O imperativo publicitário, isto é, a função objetiva de promoção do produto, acarreta uma "reação por saturação", pois as publicidades neutralizam-se mutuamente - ao mesmo tempo em que persuadem, também dissuadem. No entanto, o investimento enorme que se faz na publicidade aponta para sua eficácia em algum outro tipo de operacionalidade, além dessa que caracteriza o imperativo publicitário.

A publicidade joga com a presença e a ausência de um coletivo global imaginário e consumido. A publicidade é hábil: cada desejo ainda visa ao universal. Esse é o recurso sempre presente e o mais ocultado da publicidade. Se é normal que vivamos nossos desejos em referência coletiva, a publicidade se dedica, todavia, a transformar tal constância na dimensão sistemática do desejo. Ela não se fia na espontaneidade das necessidades individuais, prefere controla-las pelo funcionamento do coletivo e pela cristalização da consciência sobre esse coletivo puro (Idem, 1995). 
Para Baudrillard, tudo - inclusive a produção artística, intelectual e científica - é produzido como signo e como valor de troca. O autor esboça assim aquilo que poderá constituir uma crítica da economia do signo (Idem).

Os signos publicitários, portanto, impõe uma atividade específica, a leitura. Nesse processo de leitura, sob a falsa roupagem da liberdade, o consumidor interioriza a ordem social; enquanto a publicidade silencia sobre os processos objetivos de produção e de mercado, sobre a sociedade real e suas contradições através da profusão de suas imagens. Na publicidade, então, encontram-se as ligações características entre comunicação e mercado da chamada cultura pós-moderna, com suas interpenetrações e implicações mútuas, assim como no texto publicitário circulam elementos de cultura global com sua vocação de realizar as comunicações transnacionais da era da globalização (Idem, 2000).

\begin{abstract}
A alusão às sociedades primitivas é sem dúvida perigosa. Importa, no entanto, recordar que, originalmente, o consumo de bens alimentares e suntuários não correspondem a uma economia individual das necessidades; é uma função social de prestígio e de distribuição hierárquica. Não provém inicialmente da necessidade vital ou do direito natural, mas sim de um constrangimento cultural (Idem, 1995, p. 10).
\end{abstract}

Para Baudrillard a hipótese que fundamenta a análise sociológica do consumo diz que à medida que os objetos se multiplicam e diferencial não é a relação com as necessidades e o seu valor de uso, mas sim o valor de troca simbólico, de prestação social, de concorrência e de discriminação de classe social.

Segundo Veblen apud Baudrillard (Idem), um dos maiores expoentes de prestígio, além da riqueza é a ociosidade exercida diretamente ou por procuração. É sempre naquilo que tem de inútil, fútil, supérfluo, decorativo, não funcional, que se constituem categorias inteiras de objetos ou em cada objeto, todas as conotações e o metabolismo das formas, o jogo da moda etc.; em suma, os objetos nunca se esgotam naquilo que servem, e é neste excesso de presença que ganham significação de prestígio, que designam o ser e a categoria social do seu possuidor. 
É importante entender que além da evidência prática dos objetos e da espontaneidade dos comportamentos, a obrigação social do consumo ostentatório, direto ou por procuração; que assume a dimensão permanente da hierarquia social.

\begin{abstract}
Os objetos, a sua sintaxe e a sua retórica, remetem, portanto aos objetivos sociais e para uma lógica social. O que nos falam, não é tanto de práticas técnicas, como de pretensão social e de resignação, de mobilidade social (...). Através de seus objetos, cada indivíduo e cada grupo procuram o seu lugar numa ordem. É uma sociedade estratificada que fala; e se os objetos, como, aliás, os mass media, parecem falar a todos, é certamente para voltar a colocar cada um no seu lugar. Numa palavra, sob o signo dos objetos, sob o selo da propriedade privada, é sempre de um processo social contínuo do valor que se trata. $E$ os objetos são também, sempre e em toda parte, além de utensílios, os termos e a confissão desse processo social do valor (BAUDRILLARD, 1995, p. 20).
\end{abstract}

A publicidade e a propaganda estão assumindo um poder cada vez maior sobre a sociedade e o campo da cultura e da comunicação. $O$ gerenciamento relacionado às decisões estratégicas mercadológicas é delegado aos profissionais de Comunicação Integrada e isso thes confere o papel de administradores da atualidade nos setores: empresarial; artístico; político; e econômico.

A capacidade criativa e a interação com diversos públicos concedem aos profissionais o quinto poder na sociedade. Os publicitários são os prestidigitadores do futuro, especialistas em criar imagens, instituir signos, produzir ícones e criar a realidade.

O reconhecimento se dá à imagem, o valor é conferido pela representação, e não pela significação. As estratégias de Comunicação trabalham na forma e não no conteúdo dos novos significados objetivando alcançar os seus consumidores, que não buscam nada, além disso.

Para Baudrillard (Idem), esta nova era instaurada pela imagem rompe todos limites da farsa e falsificação. "Nós já transgredimos tudo, inclusive os limites da cena e da verdade (...) Não haverá mais juízo final. Nós já fomos além dele". 
Os meios de comunicação transformaram-se em mercadorias, submetidas ao modelo mercadológico da oferta e da procura visando o lucro. São produzidos e vendidos sob a mesma lógica que produz e vende produtos de consumo de massa. O conteúdo é preterido em função de mensagens instantâneas ilustradas e chamativas na busca do emocional ao invés do racional. Para Baudrillard (1990), o imperativo não passa de um álibi para a realização da operação na qual a própria publicidade transforma-se em mercadoria. A lógica dessa operação que pode ser entendida como um mecanismo de ilusão cujo objetivo é garantir a crença em uma predeterminação dos papéis sociais. A publicidade faz crer em uma sociedade gratificadora, a qual se colocaria a serviço dos desejos do consumidor.

Os discursos retórico ou informativo não possuem efeito decisivo sobre o comprador. Ele não acredita na publicidade mais do que a criança no Papai Noel. O que não o impede de aderir da mesma maneira a uma situação infantil interiorizada e de se comportar de acordo com ela (BAUDRILLARD, 1990, p. 273-280). 


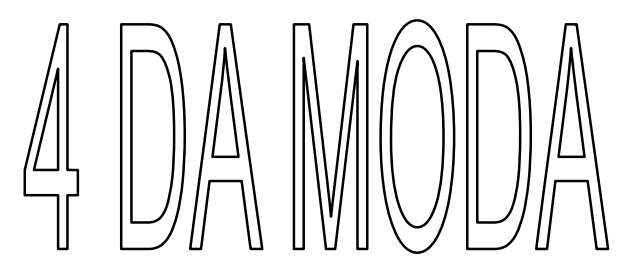




\subsection{PANORAMA DA MODA: DA ERA PALEOLÍTICA AO \\ SÉCULO XXI}

Ao observar a história da moda e da vestimenta, nota-se que ambas estão em constante mudança, uma vez que as diversas formas de ver e de adotar um vestuário estão inseridas no desenvolvimento da sociedade como um todo. Assim, ao verificar o modo como as pessoas usam as roupas e como as adaptam ao seu estilo de vida, é possível entender que esse processo antecede a era Cristã (a.C.) e perdura até a sociedade atual.

Com o avançar dos séculos, as mudanças na moda passaram a ser tantas e tão rápidas, que surgiu uma dificuldade natural em distinguir as peças e seu tempo. Formas mudaram, linhas variaram, comprimentos subiram e desceram, surgiram tecidos elaborados e simples, enfim, diversas variações foram sendo registradas, especialmente nos últimos cem anos (FEGHALI; DWYER, 2001, p. 37).

A preocupação em cobrir o corpo, portanto, já é percebida na préhistória. Na cultura Paleolítica, por exemplo, com a sucessão de eras glaciais ocorridas na Europa, as pessoas aproveitavam as peles de animais, faziam roupas e as prendiam ao tronco, por meio de agulhas - nesse caso, espinhos que deram origem aos alfinetes utilizados hoje em dia - para afastar o frio. Do mesmo modo, no período Neolítico constata-se, entre os primitivos, o freqüente uso da lã que era retirada das ovelhas para que aqueles se cobrissem e se aquecessem (LAVER, 1989, p. 8).

Os egípcios, assírios, gregos e romanos, por sua vez, costumavam utilizar um traje conhecido como sarongue - uma espécie de saia feita por um retângulo de tecido enrolado na cintura - nos primórdios da civilização. Os babilônios do século VI a.C. usavam túnicas franjadas, além da Iã, do linho e da nobre seda que eram buscados em lugares como a China pela rota das Caravelas (Idem, p. 11-15).

Também é possível perceber, nesse período, que os persas adotaram as calças e as jaquetas - as chamadas peças repartidas ou bifurcadas - que, para a época descrita, apresenta uma evolução, já que a 
indumentária mais utilizada no Antigo Império (1500 a.C.) era o chanti - um pedaço de tecido longo, parecido com uma tanga, enrolado no quadril dos homens e preso por um cinto, cuja função era cobrir toda a região lombar (FEGHALI; DWYER, 2001, p. 38; LAVER, 1989, p. 18).

No Novo Império (1500 a.C. - 332 a.C.) os egípcios habituaram-se aos calasieres - túnica longa e franjada. Os sacerdotes preferiam as vestes com representações de animais que, na visão deles, eram como figuras divinas. As mulheres, em compensação, deixavam os seios descobertos e usavam saias de várias camadas. E, a civilização Creta, preferia a cintura bem apertada, cujo efeito fino era estimulado desde a infância pelo uso de um cinto rígido (Idem, p. 38-39; Idem, p. 18-22).

A partir do século VII ao século I a.C., nota-se que os homens e as mulheres egípcias utilizavam o quíton, caracterizado por uma túnica longa e pregueada que, no primeiro caso, descia até os joelhos e, no segundo, até o tornozelo. Essa veste era feita de tecidos bem coloridos para ocasiões corriqueiras e, quando branca, simbolizava a pureza para aqueles [especialmente os nobres] que freqüentavam eventos mais formais, como o teatro (Idem, p. 38-39; Idem, p. 18-22).

No início da Idade Média - em meados de 476 d.C. - verifica-se que o Império do Ocidente passou a receber influência do Oriente através dos povos bárbaros que, por sua vez, em oposição aos romanos que utilizavam roupas mais simples, preferiam um colorido alegre. "Nesse período, a roupa dos bárbaros se institucionalizava. Com a aproximação do século XII, o vestuário começa a se sofisticar". Contudo, é possível verificar que, embora o povo bárbaro começasse influenciar a maneira de vestir dos romanos, esses achavam à maneira daqueles usarem calções ou calças largas, uma barbárie (Idem, p.42-43).

Com o passar dos tempos, entre 481-752 d.C., constata-se que o povo merovíngio, especialmente os homens, passaram a usar túnicas de linho até os joelhos, bordadas nas extremidades e presas por um cinto de couro conhecidas como gonelles. Já, as mulheres, vestiam a stola que também se caracteriza por uma túnica adornada, porém, com faixas bordadas. Em ambos 
os casos, os braços ficavam descobertos e a roupa era presa aos ombros por um broche (LAVER, 1989, p.51).

Ao observar os trajes dos reis da Inglaterra, nesse período, é plausível perceber a simplicidade das cores e das formas das túnicas. Essas costumavam ser amarelas com uma estreita borda dourada. Eles adotavam também uma capa azul e meias na cor vermelha. Nota-se, portanto, que mesmo com a chegada dos dinamarqueses no país, pouca coisa mudou na maneira daqueles se vestirem, exceto o cabelo que passou ser mais comprido e o uso do bracelete, freqüente. Outra influência levada à Europa naquele momento foi o uso do véu utilizado pelas mulheres do Oriente, nesse caso, das mulçumanas (LAVER, 1989, p.53-56).

Na segunda metade do século XIV é que a moda começou a surgir. Mais precisamente, junto com o Renascimento, entre os séculos XV e XVI. Nesse momento, tanto o vestuário feminino quanto o masculino adquiriram novos formatos. As mulheres começaram a adotar um vestido justo, com mangas também justas e longas. A inovação do período é o decote que procurou valorizar o colo feminino. Foi abandonado por elas o uso do véu, anteriormente influenciado pelas mulçumanas. Esse passou a ser utilizado apenas por freiras e viúvas (FEGHALI; DWYER, 2001, p. 66).

A moda surgiu historicamente como prática social na Europa durante o século XVI e é, certamente, o seu desenvolvimento que desde então despertou o interesse por se conhecer e estudar roupas. Isto significa entender que a indumentária se constituiria gradativamente como um assunto que merecia reflexão à medida que se estabeleciam novas práticas relacionadas à atividade de vestir o corpo (ALMEIDA, 2002, p. 198).

No que tange o vestuário masculino, esse igualmente sofreu modificações em meados do século XV por influência da moda. O gibão - peça usada por baixo do paletó que envolve o corpo do pescoço à cintura - ficou extremamente curto; os ombros, almofadados, para aumentar a largura aparente do corpo e; as mangas, bufantes. Ressalta-se que, nessa época, aumentou a incidência de variados chapéus e de pontudos sapatos, cuja tendência é averiguada desde 1360 (LAVER, 1989, p. 68-71). 
No decorrer do mesmo século XV, verifica-se também certa divergência dos hábitos italianos frente à Europa Medieval. Com a virada de século, já é percebida uma influência germânica nas roupas elegantes, tanto na corte francesa [especialmente] quanto na Inglesa. Essa veste alemã, conhecida como schaube - sobretudo com formato de batina, sem mangas, com ar acadêmico - ainda é utilizado pelo clero até os dias de hoje. Contudo, em meados do período mencionado, tal influência mudou. As cores vivas e as formas fantásticas utilizadas pelos alemães que, por sua vez, encantaram a Europa, deram lugar à sombria e justa moda espanhola. Havia, portanto, uma diferença real dessa voga com relação à anterior. O corte passou a apresentar, além da ausência de cor, acolchoado, cintura fina e tricô (Idem, p. 74-90).

As principais mudanças ocorridas na indumentária feminina - a partir da metade do século XVI - foram o rufo, o decote, o corpete que formava a frente da blusa, as mangas bufantes e a saia armada. O rufo surgiu na Europa em 1570 e sua função - no caso dos homens - foi de manter uma postura de desdém, uma vez que o mesmo conservava a cabeça erguida em sinal de privilégio. No que tange as mulheres, o rufo teve papel de atribuir-lhes sedução, de tentar explorar seus encantos. O decote, por sua vez, conferiaIhes status na sociedade no qual estavam inseridas. Já, a saia armada, surgiu na Inglaterra por volta de 1545 e seu uso só não era freqüente entre as trabalhadoras que precisavam de roupas mais flexíveis para se movimentar com facilidade durante o serviço (Idem, p. 91-97).

Ao verificar o vestuário masculino dessa mesma época é possível perceber que o gibão ainda era a peça principal, porém, as roupas de baixo começaram a apresentar variações. Um exemplo é a introdução das meias que passaram a ser costuradas aos calções, formando uma espécie de meia-calça. Nos pés já se utilizavam sapatos levemente arredondados, geralmente confeccionados de materiais como o couro, a seda ou o veludo, cuja inovação foi a introdução do salto alto no final do século (Idem, p. 99-102).

A partir da segunda metade do século XVI nota-se, portanto, que a Espanha passou a influenciar a moda européia - sobretudo a Holandesa - e que essa influência prosseguiu no século seguinte através do corte conservador das vestes e da tonalidade escura, como o preto. Nesse período, 
o rufo utilizado na França e na Inglaterra diminuiu, cedendo lugar à gola caída, cada vez mais sofisticada - em oposição à Holanda que aumentou o tamanho do rufo até o mesmo apresentar o aspecto de uma roda de carroça, de linho pregueado (Idem, p. 103-108).

Em meados do século XVII - momento em que a França começa a se colocar como o país da moda - as roupas femininas ditavam um aspecto mais natural através do corpete, extremamente decotado e amarrado com fitas de seda, das anáguas, das becas e das mangas almofadadas e bufantes. Os trajes masculinos passaram a ser associadas aos três mosqueteiros, principalmente os franceses, já que os mesmos começaram a utilizar capas mais curtas pendendo dos ombros, chapéus de abas largas adornados com uma pluma e botas. A roupa inglesa, por outro lado, associava os homens aos calaviers [cavaleiros], embora a veste também consistisse em capas, chapéus plumados e botas (Idem, p. 103-108).

No século XVII, (...) que a França começa a se colocar como grande produtora de moda. Surgem as primeiras publicações especializadas no assunto. Nesse período, 20\% da produção francesa eram de materiais para o vestuário (FEGHALI; DWYER, 2001, p. 45).

Ao observar o período anteriormente mencionado, nota-se que a França passou a determinar o tom da moda, uma vez que todo o prestígio da indumentária européia surgiu de lá. O efeito geral das vestes femininas dessa época permaneceu estático, só as saias que adquiriram uma aparência mais formal, mas as roupas masculinas passaram por transformações durante 0 século XVII, ao receberem um toque mais moderno. Verifica-se, também, que entre 1660-1699 a principal mudança ocorrida na corte francesa foi a introdução da peruca por parte dos homens elegantes. Essa era comprida e cacheada e a cor predominante era a branca. Quanto às mulheres, essas não adotaram a peruca, mas usavam um penteado elaborado conhecido por fontange que foi tão característico na década de 1690 (LAVER, 1989, p. 109124).

O século XVIII distingue-se, cada vez mais, pelo domínio da França na confecção de roupas elegantes. Utilizar um traje francês era sinônimo de poder aquisitivo e de bom gosto, mas, a partir de 1715, de flexibilidade, já que a indumentária feminina ficou mais solta e com linhas mais fluídas. Essa nova Era caracteriza-se pelo conforto na composição das roupas. Nesse período, as vestes femininas buscaram a amplidão, uma vez que as 
saias se abriram para os lados. A roupa masculina, em contrapartida, não demonstrou sinais de mudança no começo do século. Sua composição básica formava-se por casaco, colete e calções. No pescoço, manteve-se a tradição do plastron e, na cabeça, o chapéu tricórnio (Idem, p. 127-136).

Por volta de 1760, já são percebidos vestígios de um novo costume no jeito dos europeus de vestirem. Nota-se uma ênfase maior ao estilo do "campo" dos ingleses a partir do momento em que há uma tendência para a simplicidade e para a praticidade no modo das pessoas se alinharem. Verificase que o chapéu tricórnio foi substituído por cartolas que, por sinal, é um esboço da moda masculina no século XIX; os "alfinetes duplos" - ou os grampos de cabelo que são conhecidos atualmente - começaram a ser utilizados; os penteados femininos se elevaram; os arcos das saias cederam lugar às anquinhas; o corpete começou a ser mais estufado; no decote, usavase um lenço para cobrir o colo.

Enfim, nota-se que a característica da indumentária européia do Novo Regime era menos extravagante, no caso das roupas femininas e mais simples e campestre, nas vestes masculinas. Assim, vale lembrar que no final do século a roupagem - especialmente a feminina - mudou tanto que os paniers, as anquinhas e os espartilhos foram substituídos por um traje jamais usado pelas mulheres de séculos anteriores. Essa veste é conhecida por robe en chamise que se distingue por se parecer com uma peça de baixo, uma vez que o vestido é branco, de cintura alta, tão transparente, que era necessário usar uma malha cor-de-rosa por baixo para que o corpo feminino não ficasse à mostra.

No final do século XVIII a moda estabelecida na Europa já era a versão de um vestido Imperial para as mulheres e um traje típico inglês para os homens (LAVER, 1989, p. 137-153). No que diz respeito à moda brasileira até o século XVIII - essa era baseada no vestuário português, portanto, nada de autenticidade frente à alfaiataria européia. No século seguinte é notável que o vestuário do Brasil recebesse influência do africano que, por sua vez, se difundia pela Bahia, o que o transformou em uma criação exclusivamente nacional (Idem, p. 48).

O século XIX, em compensação, é marcado pela transição do mundo antigo para a modernidade. Na entrada do período é plausível perceber a influência da França e da Inglaterra na moda. Os franceses considerados experts na confecção de roupa feminina e, os ingleses, reconhecidos pela habilidade na alfaiataria foram treinados para trabalhar com a casimira, tecido bastante utilizado nos trajes masculinos da época. Por isso, verifica-se que a vestimenta típica feminina do início do século era uma espécie de camisola 
comprida - até os tornozelos - extremamente decotada e caracterizada por um tecido leve. A novidade do traje, a mais nova paixão pelo xale sobre a roupa, o que marcou a elegância da mulher na sociedade em que vivia.

$\mathrm{Na}$ década de 1814 é que a divergência entre a alfaiataria e a preferência por roupas francesas e/ou inglesas se tornaram mais evidentes. Nesse momento, as francesas costumavam usar saias ligeiramente aberta na barras e o tom predominante das roupas era o branco. Por outro lado, as inglesas optavam por um ar mais romântico, mais elisabetano, com as mangas dos trajes mais fofas. Contudo, nesse confronto de vogas, as últimas cansaram de suas vestimentas e adotaram finalmente à moda típica da França. Em oposição aos homens que, por sua vez, mesmo sendo franceses, eram constantemente influenciados pela moda característica inglesa (Idem).

No que tange os chapéus da época, é possível perceber que as cartolas eram usadas a qualquer hora do dia, exceto durante a noite, horário propício para o uso do bicorne - chapéu com formato de lua crescente, com as duas abas apertadas uma contra a outra. Os cabelos masculinos eram curtos e despenteados à la titus [penteado típico da época]. Os civis habitualmente se barbeavam, mas os militares costumavam usar costeletas e bigode (Idem, p. 155-160).

A partir de 1822 é plausível compreender que a roupa feminina passou por consecutivas transformações. A cintura voltou a posição normal e ficou mais fina, em oposição ao que era antes: alta. A saia passou a ser novamente rodada e as mangas fofas. Entretanto, em 1830, a saia se encurtou e se ampliou e as mangas aumentaram substancialmente. Do mesmo modo, em 1837, a moda feminina voltou a mudar e com ela, as mangas que já não eram tão amplas e, por sua vez, desciam pelos braços. Igualmente as saias ficaram tão compridas que era impossível apreciar os tornozelos das mulheres quando essas andavam. Contudo, a principal alteração da moda feminina no período foi a adoção de um chapéu tipo boneca que se caracterizava pela amarração do mesmo sob o queixo e as sapatilhas que tinham o papel de deixar as mulheres tão pequenas quanto possível. No entanto, em meados de 1840, o universo feminino se voltou para a equitação, tanto que as revistas especializadas em moda mostravam trajes de montaria exclusivamente para elas. Curioso que o mesmo era masculinizado somente até a cintura. A saia foi mantida, mas ficou tão volumosa que, mesmo sentada no lombo do cavalo, essa se arrastava pelo chão. Tal fato se deu para mostrar que apenas àquelas 
que pudessem pagar um criado para ajudá-las a montar e a descer do animal é que poderiam arcar com os custos dessa ostentatória vestimenta (Idem, p. 168175).

No que diz respeito à indumentária masculina da época é possível perceber que essa ficou mais sóbria. A cintura apertada, os ombros almofadados, os coletes $\mathrm{e}$ as peles foram deixados de lado. $O$ que predominava nesse momento era a ausência da extravagância e das cores berrantes que só retornaram à ativa, em momentos mais modernos. "Por volta de 1850, a hegemonia do terno com gravata e uma sobriedade de cores passam a caracterizar a indumentária masculina. A fantasia e a decoração eram reservadas às roupas das mulheres" que se caracterizavam pelo excesso de anáguas que, por ficarem muito pesadas junto ao corpo, foram substituídas por anáguas de arco - as chamadas crinolinas de armação - por volta de 1856 (Idem, p. 168-169).

Essa estrutura surgiu para o conforto feminino. Isso porque, livres do exagero de camadas e de anáguas, as mulheres se movimentavam livremente dentro do arco. Só as pernas que ainda não podiam ser mostradas a terceiros, tanto que mesmo dentro dessa gaiola, as mesmas utilizavam calças tipo pantalona, de linho, rendadas na barra, até os tornozelos, para evitar quaisquer infortúnios. Assim, a crinolina durou quase 15 anos e, nesse período, passou por diversas alterações até que em 1860 foi eliminada completamente. Em seu lugar, surgiu a anquinha que também perdurou até 1870 e cedeu espaço a um estilo de saia com uma cauda longa. Na década de 1880 é percebido o ressurgimento da anquinha, só que em uma outra versão. A mesma se projetava horizontalmente nas costas. Contudo, esse modelo de saia, caracterizado pela "anca", desapareceu de vez em meados de 1890, juntamente com os drapeados horizontais nas saias. Os vestidos já eram lisos sobre os quadris; as saias, compridas e em forma de sino, com uma cauda (Idem, p. 168-169).

Outra alteração ocorrida no vestuário feminino em meadas de 1840 foi a substituição das sapatilhas pelas botas com saltos altos, amarradas até o meio das canelas. Também, verifica-se que a partir de 1870 as cores suaves foram substituídas por aquelas mais berrantes e mais vibrantes. Do 
mesmo modo, o chapéu boneca foi trocado por outros menores, caídos sobre a testa e usados sobre um penteado alto. As mangas, por sua vez, adquiriram proporções enormes por volta de 1894, assim como, ocorreu a introdução de um traje bifurcado que foi elaborado para que as mulheres pudessem andar de bicicleta - esporte que se tornou bastante popular no momento - sem que as mesmas arrastassem as saias pelo chão (Idem , 1989, p. 184-185; 190-191; 208).

Os trajes masculinos da década de 1890, em compensação, não eram muito diferentes dos da década anterior. As vestes mais comuns eram os fraques para serem utilizados a noite, a sobrecasaca para o dia e o casaco para a manhã. Além disso, nota-se uma forte incidência de casacos de marujo entre os homens que são reflexos da influência do esporte, principalmente, do iatismo em meio à população. Também, percebe-se que as calças do início da década de 1890 eram mais folgadas em cima e as pernas, mais afuniladas. Só os mais jovens que costumavam usar a calça com a bainha dobrada (Idem, $p$. 202-206).

A partir do início do século $X X$, nota-se que a moda passou por um momento de ostentação e de extravagância. As mulheres adotaram uma saia lisa sobre os quadris que se abria em direção ao chão, formando um sino. No decote, um excesso de renda descia colo abaixo. As mangas, já eram justas e compridas o suficiente para chegarem até o meio da mão. Os homens, imediatamente se habituaram a sobrecasaca e a cartola. Nas pernas, calças bastante curtas e estreitas. Só os rapazes que as usavam com a bainha virada e com um vinco na frente (Idem, p. 213-221).

O período compreendido entre o início do século XX e o princípio da Primeira Guerra Mundial é marcado por grande ostentação e extravagância. A moda, como sempre, refletia a época. (...). A roupa tinha de ser adaptada ao ritmo acelerado que as cidades estavam gerando (Idem, p. 48).

Em meados de 1908, portanto, a silhueta feminina deixou de ser moldada em formato de "S" - aquela que, através dos espartilhos, empinava 0 busto para frente e o quadril para trás. Os chapéus se tornaram maiores, o que fez com que os quadris parecessem menores. Em 1910, o vestuário feminino sofreu uma modificação fundamental: as cores se tornaram espalhafatosas; as saias, estreitas nas barras; os vestidos, adornados com renda e botões. Em 1913 , as golas que até então eram levantadas até o pescoço, cederam lugar ao 
decote "V"; os chapéus, também ficaram menores antes da primeira guerra e, a extravagância, deixou de ser o foco principal da indumentária, uma vez que a partir desse momento, as mulheres perceberam que era inútil esse tipo de comportamento em períodos de conflito (FEGHALI; DWYER, 2001, p. 222229).

No entanto, percebe-se que a alta moda voltou ao seu ritmo normal a partir de 1919, quando o universo feminino passou a se vestir e a se comportar diferentemente do que costumavam antes do combate. A saia, que era ampla, passou a ser "barrete", com o efeito tubular. O busto era de menino; a cintura desapareceu; os cabelos cacheados ficaram curtos e lisos. Ou seja, nesse momento, todas as curvas femininas foram abdicadas para que essas se adaptassem à nova voga. Não obstante, nota-se ainda que a década de 1920 seja conhecida pelo talento protuberante de Coco Chanel que, diferentemente de muitos estilistas da época, soube se adaptar à nova tendência do pósguerra (Idem, 2001, p. 50; LAVER, 1989, p. 230-232).

Ao observar, portanto, o período compreendido, nota-se que as mudanças na maneira dessas pessoas se vestirem foram tantas que, entre 1925-1927, é possível considerar a maior revolução no que tange o comprimento das saias. Essas, para o escândalo de muitos, ficaram curtas como jamais foram no decorrer do século XX. Porém, logo se fizeram tentativas de alongá-las novamente à medida que a década chegava ao fim. Do mesmo modo, as mulheres deixaram o cabelo crescer outra vez; as mangas compridas voltaram a ser usadas; os ombros largos e os quadris estreitos passaram a ser o estereotipo do momento (LAVER, 1989, p. 234-240).

A década de 1930, por sua vez, caracteriza-se pelo destaque dado às costas que acabaram sendo desnudadas. Tais roupas foram influenciadas pela evolução ocorrida nos trajes de banho. Esses eram recatados até 1920 e, a partir de 1930, com a moda de se tomar banho de sol, as roupas passaram a ser mais decotadas atrás. Também é possível verificar que, nessa época, os saiotes foram reduzidos; a cavas, aumentadas e o decote, ampliado (Idem, p. 240-242).

Por outro lado, ao observar a ocasião que compreende a Segunda Guerra Mundial, é plausível perceber que novamente o vestuário sofreu a influência do período instaurado. No entanto, verifica-se que a silhueta feminina começou a ser modificada; a saia adquiriu um estilo camponês, além de ficar mais curta e franzida. As vestes masculinas, em contrapartida, caminharam em sentido à informalidade, já que a freqüência de uso de trajes como a casaca e o casaco para a manhã diminuíram, sendo, portanto, usados em ocasiões mais formais, como funerais e casamentos. Todavia, a principal mudança ocorrida no vestuário masculino no decorrer de 1920 foi na largura das calças, a chamada Oxford Bags que permaneceram muito largas até o final da década e se afunilaram um pouco mais em meados de 1930 (LAVER, 1989, p. 246-250).

Por volta de 1940, em compensação, já se pode perceber que a guerra praticamente interrompeu o curso da moda. Nesse período, a mão-deobra e os tecidos ficaram limitados; a matéria-prima, escassa e os estilistas; barrados com suas idéias inovadoras, o que dificultou a elaboração de peças novas e extravagantes. Nesse sentido, afirma-se que a Segunda Guerra Mundial mudou toda a estrutura dessa indústria, uma vez que as roupas da época de conflito passaram a refletir a situação vigente no momento. Tanto, que as vestes - especialmente as femininas - faziam alusão às fardas: com 
ombros quadrados, retos, de corte masculino, cor de debrum e bolsos falsos. As saias já eram mais curtas, tinham pregas finas e eram franzidas a uma blusa justa (Idem, p. 252-254).

Os Estados Unidos, com menos restrições, começaram a desenvolver sua própria linguagem de moda. E, ao final da guerra, as bases de uma alta-costura independente e de uma indústria visando à massa ficaram claras, revelando um gosto diferente do europeu (FEHALI; DWYER, 2001, p. 51).

Em 1945, depois de uma exposição no Musée des Arts Décoratifs, Paris voltou a ser o centro da moda. Mas, não era mais a única, já que a Inglaterra e os Estados Unidos começaram a ter suas produções independentes (LAVER, 1989, p. 255). Entretanto, após esse período escasso, surgiu a tendência para o luxo e para a nostalgia, uma vez que as mulheres européias desejavam substituir aquelas roupas de corte masculino por saias mais dançantes. Aí que surgiu o New Look. A veste masculina, por sua vez, passou a produzir um look "eduardino", com os paletós mais compridos e ajustados e as calças mais apertadas (Idem, p. 256-259).

Percebe-se, deste modo, que as parisienses da década de 1950 começaram a despender de mais tempo para cuidar da própria aparência. A beleza passou a ser fundamental no pós-guerra, pois as mesmas já podiam encontrar todos os cosméticos com mais facilidade, o que não acontecia anteriormente, em momentos de conflito, escassez típica dos combates.

Fora desse contexto, as jovens européias cansaram de utilizar versões mais modernas das roupas de suas mães. Elas queriam ter sua própria moda, sua própria identidade. Tanto, que alguns figurinos jovens baseavam-se no sportwear, nas peças separadas e nos artefatos versáteis dos Estados Unidos que, por sua vez, compreendiam-se por calças tipo cigarrete, sapatos mais baixos, parecidos com sapatilhas e, o jeans que, se popularizava (Idem, p. 260) .

Deste modo, nota-se que a década de 1960 foi baseada nos adolescentes e nas suas vontades. Os modelos mudavam constantemente para se adaptarem à nova realidade juvenil. Porém, essa mudança era tão rápida que os diversos fabricantes tinham dificuldade para renovar seus estoques com a mesma agilidade em que os jovens desejavam trocar de 
modelos. Nesse período, as saias ficaram mais curtas do que já foram em meados de 1920. Os cabelos; compridos e soltos (Idem, p. 262).

As roupas de 1960 passaram por diversas modificações e tendências, uma vez que os trajes adquiriram inúmeras formas: desde as mais duras às geométricas. Essas eram eróticas no tanto que desnudavam o corpo. Como exemplo, o comprimento da saia que, nessa época, chegou à altura da coxa. Igualmente, os decotes se aprofundaram e as blusas e tecidos ficaram mais transparentes. Além disso, a peça de baixo se adaptou a nova voga. Tanto que as calcinhas ficaram menores para serem usadas com minissaias saint-tropez - cintura abaixo do umbigo. Posteriormente, as malhas justas entraram na moda à medida que as saias se alongaram mais (Idem, p. 263265).

Ao observar, portanto, o período mencionado, nota-se que a maior parte dos jovens adquiriu um estilo próprio e, por sua vez, tinha o direito de mudá-lo constantemente se quisesse: ultrapsicodélicos; geométricos; retro; românticos; ou orientais. Igualmente, os tecidos sempre mudavam de cor, de textura para se adaptarem a nova era. Surgiram as fibras naturais; os sintéticos se popularizaram e, ao mesmo tempo, eram fáceis de cuidar e dispensavam o ferro de passar (Idem p. 265).

A moda, entretanto, é diferente; logo que um item se exaure, outro toma o seu lugar e assim por diante. Outro nome para esse ciclo de obsolescência internamente construído ou planejado é moda. Conseqüentemente, o desejo por outro modelo, o mais recente possível, é instantaneamente satisfeito pelo ciclo da moda na pós-modernidade. Esse ciclo é o desejo pela diferença sem fim (BERNARD, 2003, p. 227).

No final da década de 1960, a atmosfera da moda novamente começou a mudar. A partir desse momento, já são verificados tecidos mais finos, de algodão, com estampas florais, motivos campestres, chifons estampados, chapéus de palha adornados com flores e penteados levemente ondulados. Essa mudança ocorreu porque a rebeldia apontada nos jovens, no período anterior, começou a perder a força, cedendo lugar a pessoas que 
almejavam a tranqüilidade e um estilo de vida mais simples (LAVER, 1989, p. 268-269).

Nesse período, a alta moda realçou mais o quadril, logo que as calças jeans ficaram mais apertadas e as malhas, colantes. Observa-se que em meados de 1970, a preocupação com a saúde, as corridas e caminhadas entraram em voga. Por isso que as roupas se modificaram nesse sentido (Idem, p. 270).

No que tange as roupas femininas para 0 trabalho especialmente os paletós e as jaquetas - passaram a apresentar cortes basicamente masculinos entre 1870-1980, uma vez que as mulheres começaram a tentar se igualar aos homens nesse aspecto. Por outro lado, as vestes masculinas se tornaram menos formais na medida em que poucas profissões exigiam o uso do terno. Assim, os homens começaram a usar camisas listradas, com estampas florais e, até mesmo, camisetas de beisebol e de algodão. A camisa, também tinha a cintura mais fina em meados de 1970 e, as jaquetas mais usadas, eram as esportivas (Idem, p. 272).

Ao observar, portanto, essas mudanças, tanto no vestuário masculino quanto no feminino, desde a Primeira Guerra Mundial, as vestimentas começaram a apresentar uma qualidade de unissex. Esse fator é verificado nas jaquetas de aviador e nas camisas adotadas pelas mulheres do determinado período e, nas calças esportivas, listradas e/ou coloridas usadas pelos homens. Por outro lado, no final da década de 1970, verifica-se também a influência marginal na alta costura: a moda que saiu dos guetos para as passarelas. Nessa ocasião, o penteado punk, ouriçado, tingido de vermelho, verde, amarelo e azul nas raízes e, as correntes usadas nas pernas das calças, viraram moda (Idem, p. 273-274).

Em 1980, a alta-costura evaporou-se. As mulheres passaram a adquirir mais conhecimento sobre cortes e tecidos, o que facilitou a criação de looks próprios. Do mesmo modo, os estilistas americanos se preocupavam em deixar as roupas mais confortáveis e as linhas mais simples, tanto que as peças brancas entraram em voga (FEGHALI; DWYER, 2001, p. 54). 
No que se refere ao Brasil, foi nessa década que surgiram as primeiras escolas de moda no país e, a partir daí, a busca pelo conhecimento científico no assunto. Igualmente, a partir da metade de 1980 começou a preocupação, por parte dos pesquisadores, com a qualidade dos tecidos, das fibras e do acabamento. Evolução marcada pela década de 1990, passando por desenvolvimento tecnológico, com o nascimento de tecidos "inteligentes" que, por sua vez, proporcionavam um tratamento mais inusitado às roupas da época (Idem, p. 55).

Contudo, essa evolução no tratamento dos tecidos permitiu que a moda futurista começasse a aparecer no final da década de 1990. Nesse momento, também veio à tona a necessidade da sociedade moderna "ser cada vez mais prática, versátil, conceitual, veloz e criativa". O que acelerou os acontecimentos no mundo fashion, o surgimento e a exportação de modelos que, por sua vez, começaram a ganhar espaço na mídia - o que não acontecia antes - e a serem pagos em dólar pelas grandes grifes mundiais. $O$ futuro da moda, do mesmo modo, vai continuar nesse caminho, já que a chave para o sucesso no setor é a constante inovação, a renovação e a criatividade inesperada (Idem, p. 57). 


\subsection{A HISTÓRIA DO SAPATO}

Calçado é o nome dado a tudo que protege os pés como: os que cobrem totalmente - calceus, mulleus, pero, coturno e phaecasium, sapatos; botas; botinas; e, os que protegem a planta dos pés e são atados com cordões - solea, crepida, baxae, sandálias e chinelos. Os grandes borzeguins dos franceses e dos gauleses sucederam as elegantes botinas galo-romanas que as Cruzadas mudaram pelas batouches crochues, origem do famoso calçado "poulaine" - polaina (CONDE, 2004).

Os calçados são confeccionados em sua maioria em: de couro, pelica, camurça, tecidos, palhas, cordas, borracha, madeira e os artigos disponibilizados oferecem couros infinitamente variados em resistência, espessura, maciez, aspecto e cor. Sola é o material empregado para a planta dos pés, pele o couro fino usado para a parte de cima e dos lados da sola. Os saltos são de madeira, de metal ou de borracha, com a parte de cima de couro, tecido ou palha.

Existem evidências que a história do sapato começa a partir de 10.000 a.C., ou seja, no final do período paleolítico (pinturas desta época em cavernas na Espanha e no sul da França fazem referência ao calçado). Entre os utensílios de pedra dos homens das cavernas existem várias que serviam para raspar as peles, o que indica que a arte de curtir é muito antiga. Nos hipogeus (câmaras subterrâneas usadas para enterros múltiplos) egípcios, que têm idade entre 6 e 7 mil anos, foram descobertas pinturas que representavam os diversos estados do preparo do couro e dos calçados. Porém, há pesquisadores que afirmam que os sapatos foram inventados na Mesopotâmia, onde atualmente fica o Iraque, há mais de 3.200 anos. Eles eram feitos de couro macio para que os antigos pudessem atravessar trilhas montanhosas. Eram comuns sapatos de couro cru amarrados aos pés por tiras do mesmo material. Os coturnos eram símbolos de alta posição social. 
Porém o mais comum era andar descalço e carregar as sandálias usando-as apenas quando necessário (Idem).

$\mathrm{Na}$ idade média tanto homens como mulheres usavam sapatos de couro abertos que tinham uma forma semelhante à das sapatilhas (tamancos Borzeguins). Os homens também usavam botas altas e baixas atadas à frente e ao lado. O material mais corrente era a pele de vaca, de qualidade superior (MUSEU DO CALÇADO, 2006).

No Egito Antigo, entre 3.100 a.C. e 32 a.C., apenas os nobres usavam sandálias de couro. Os faraós usavam calçados deste tipo adornados com ouro (Idem).

$\mathrm{Na}$ idade média a maioria dos sapatos tinham a forma das atuais sapatilhas. Eram feitas de couro. Nobres e cavaleiros usavam botas de melhor qualidade. O rei Eduardo (1272-1307), da Inglaterra, padronizou a numeração dos sapatos. No mesmo país, em 1642, há o registro da primeira produção "em massa" de sapatos em todo o mundo: Thomas Pendleton fez quatro mil pares de sapato e 600 pares de botas para o Exército. As campanhas militares desta época iniciaram uma demanda substancial por botas e sapatos. Tanto os homens como as mulheres usavam sapatos de couro abertos que tinham uma forma semelhante à das sapatilhas. Os gregos, que criaram os preceitos fundamentais da civilização ocidental, mostraram vanguarda não só na filosofia, na ciência e na política, mas também na moda: estudos mostram que alguns chegaram a usar modelos distintos no pé esquerdo e direito. Durante o Império Romano, os calçados denunciavam a classe ou grupo social do indivíduo. Os senadores utilizavam sapatos em cor marrom, em modelos que amarravam na panturrilha por quatro tiras de dois nós. Para os cônsules romanos a cor indicada era o branco. Os calçados das legiões eram as botas de cano curto. Mulheres calçavam sapatos brancos, vermelhos, verdes ou amarelos. Em 1.500 a.c. os persas inventaram o primeiro sapato macio da história feito com tiras de couro. Os calçados eram vazados e bastante largos. Estes modelos marcaram o início da era moderna (Idem). 
No fim do século XV, foi adotado para todos os calçados bicos de pato. Depois surgiram as formas longas Henrique III, as botas quadradas Henrique IV. Sapatos e botas não tinham saltos. No século XVII começou-se a usar o salto e bem depressa se chegou ao excesso no gênero, de que o sapato chambre, do tempo de Luís $\mathrm{XV}$, voltou os sapatos planos trazidos pela moda inglesa, seguida somente pelos cortesãos. No tempo de Napoleão I foi observada a moda do século anterior, mas os homens usaram botas até a Restauração. No tempo de Luís Filipe vemos aparecer os sapatos e botinas de elástico, e a bota de verniz era escondida pela calça. Os primeiros calçados com saltos largos e botas "Mosqueteiros do Rei", século XVI. Mais confortáveis e fáceis de caminhar. A moda de calçados se caracteriza pela volta dos bicos finos. Mas este modelo é típico da Reforma Protestante, no século XVI. Durante o século XVII ocorreu a formação da Monarquia parlamentar Inglesa e o reinado de Luís XIV na França. Este sapato era típico da realeza, nesta época as classes sociais também podiam ser identificadas pelos sapatos que as pessoas usavam. A moda dos saltos aparece durante sete séculos. Modelos femininos na França e na Inglaterra, do século XVII (Idem).

No decorrer do século XVIII, a Europa Ocidental passou por uma grande transformação no setor da produção, em decorrência dos avanços das técnicas de cultivo e da mecanização das fábricas, a qual se deu o nome de Revolução Industrial. A invenção e o uso da máquina permitiram o aumento da produtividade, a diminuição dos preços e o crescimento do consumo e dos lucros. As origens da Revolução Industrial podem ser encontradas nos séculos XVI e XVII, com a política de incentivo ao comércio adotado pelos países absolutistas. A acumulação de capitais nas mãos dos comerciantes burgueses e a abertura dos mercados proporcionada pela expansão marítima estimularam o crescimento da produção, exigindo mais mercadorias e preços menores. Gradualmente, passou-se do artesanato disperso para a produção em oficinas e destas para a produção mecanizada nas fábricas (COULON, 1995). 
A Inglaterra foi o país pioneiro da industrialização. A agricultura inglesa desenvolveu-se com o cercamento dos campos e a difusão de novas técnicas e instrumentos de cultivo. $\mathrm{O}$ fim do uso comum das terras gerou o "trabalhador livre", expulso do campo onde não tinham mais condições de sobrevivência e transformado em mão-de-obra urbana. A mecanização da produção criou o proletariado rural e urbano, composto de homens, mulheres e crianças, submetido a um trabalho diário exaustivo, no campo ou nas fábricas. Com a Revolução Industrial, consolidou-se o sistema capitalista, baseado no capital e no trabalho assalariado. O capital apresenta-se sob a forma de terras, dinheiro, lojas, máquinas ou crédito. $\mathrm{O}$ agricultor, o comerciante, o industrial e o banqueiro, donos do capital, controlam o processo de produção, contratam ou demitem os trabalhadores, conforme sua conveniência. Estes que não possuem capitais vendem sua força de trabalho por um salário. Podem-se distinguir três períodos no processo de industrialização em escala mundial (Idem):

1760 a 1850 - A Revolução se restringe à Inglaterra, a "oficina do mundo". Preponderam a produção de bens de consumo, especialmente têxteis, e a energia a vapor.

> 1850 a 1900 - A Revolução espalha-se por Europa, América e Ásia: Bélgica, França, Alemanha, Estados Unidos, Itália, Japão, Rússia. Cresce a concorrência, a indústria de bens de produção se desenvolve, as ferrovias se expandem; surgem novas formas de energia, como a hidrelétrica e a derivada do petróleo. O transporte também se revoluciona, com a invenção da locomotiva e do barco a vapor.

Do ano de 1900 até hoje surgem conglomerados industriais e multinacionais. A produção se automatiza; surge a produção em série; e explode a sociedade de consumo de massas, com a expansão dos meios de comunicação. Avança a indústria química e eletrônica, a engenharia genética, a robótica (Idem). 
Quadro 1 - Evolução do Sapato

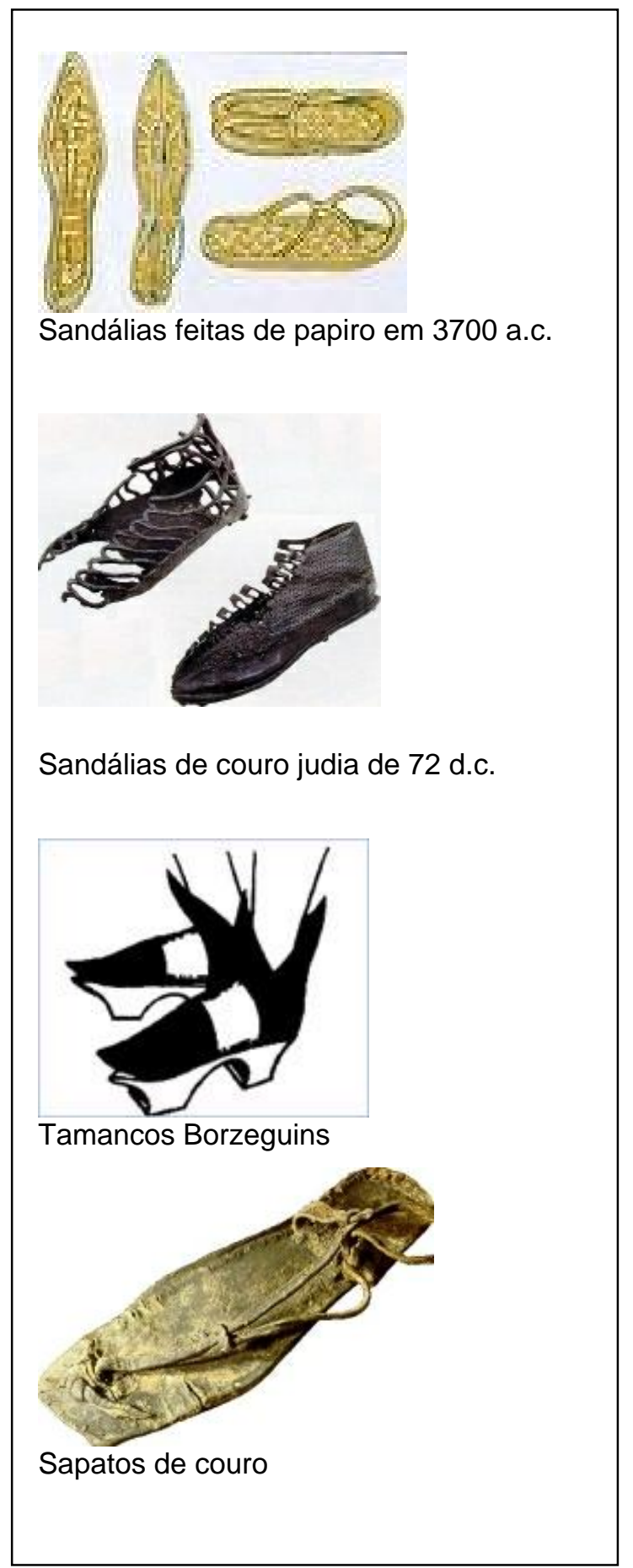

Fonte: Museu do Calçado, 2006. 


\section{Quadro 2 - Evolução do Sapato}

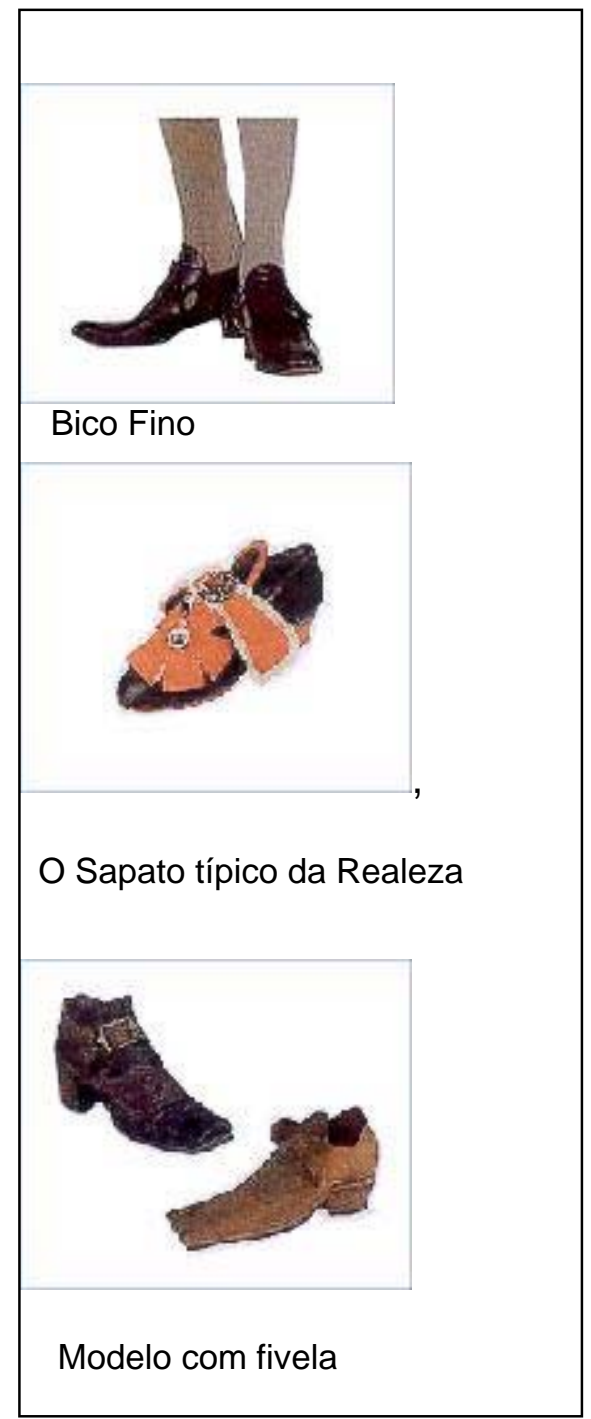

Fonte: Museu do Calçado, 2006.

A Revolução Francesa faz parte de um movimento revolucionário global, atlântico ou ocidental, que começa nos Estados Unidos em 1776, atinge Inglaterra, Irlanda, Holanda, Bélgica, Itália, Alemanha, Suíça e, em 1789, culmina na França com violência maior. O movimento passa a repercutir em outros países europeus e volta à França em 1830 e 1848. Há traços comuns em todos esses movimentos, mas a Revolução Francesa tem identidade própria, manifestada na tomada do poder pela burguesia, na participação de camponeses e artesãos, na superação das instituições feudais do Antigo 
Regime e na preparação da França para caminhar rumo ao capitalismo industrial. Foi um importante marco na História Moderna da nossa civilização. Significou o fim do sistema absolutista e dos privilégios da nobreza. O povo ganhou mais autonomia e seus direitos sociais passaram a ser respeitados. A vida dos trabalhadores urbanos e rurais melhorou significativamente. Por outro lado, a burguesia conduziu o processo de forma a garantir seu domínio social. As bases de uma sociedade burguesa e capitalista foram estabelecidas durante a revolução. Com a Revolução Francesa que, para retomar um termo de J.Burckhardt, parece ter proclamado que tudo é provisório e sempre posto em dúvida, começou o crepúsculo dos estilos históricos. Estes foram suplantados pela moda, no sentido moderno do termo e em toda sua acepção: a moda que não dura mais que uma estação e que naquele tempo marcava uma época inteira. O vapor industrializado substitui em grande parte o braço humano e a humilde roda a vapor; a máquina superou a antiga e simples ferramenta do artesão. Revolução não sangrenta, mas que custou sacrifícios não menos dolorosos, sobretudo no artesanato. A Revolução Francesa, pois, não se limitou a suprimir os privilégios de classe. Ela destruiu também a força das corporações. Esta conjunção histórica do maquinismo e do liberalismo burguês é um fenômeno, singular e, com justa razão, inexplicável. Assim estavam reunidas as prévias da industrialização. Desde esse momento, a moda entrava em uma fase nova e decisiva, enquanto que modificações profundas punham em questão a estrutura da sociedade (HOBBSBAWN, 1979). 
Figura 1: Sapato em plástico vermelho cintilante.

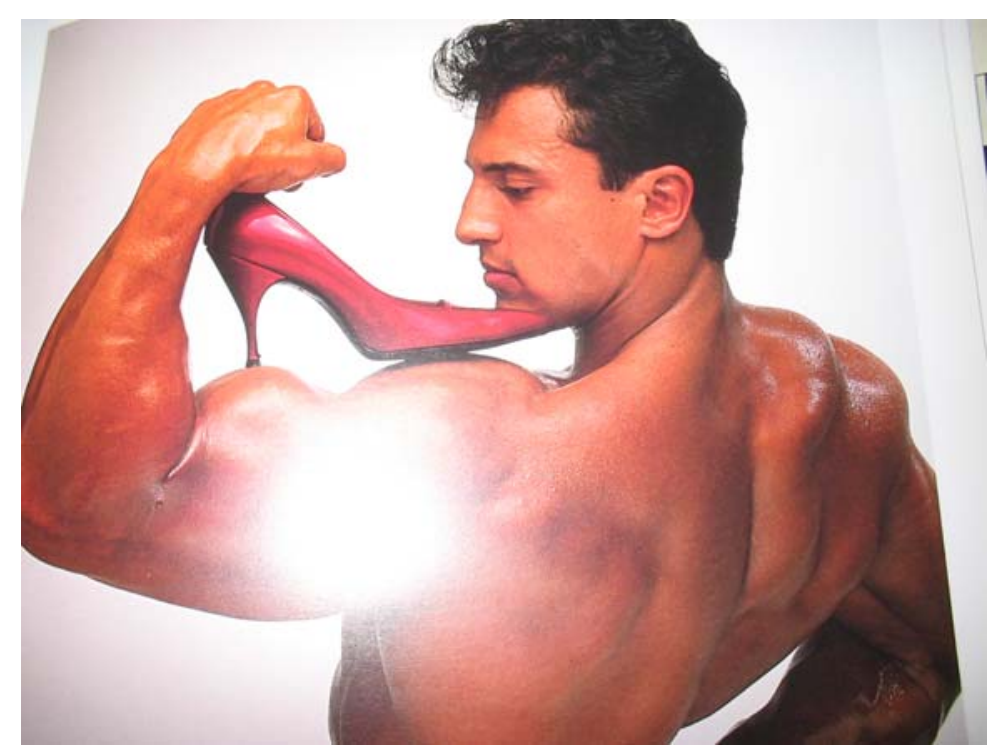

Fonte: CONDE, Linda. A história do sapato do século XX. São Paulo: Kling \& Associados, 2004, p. 73.

Em meados do século IX começam a surgir as máquinas para auxiliar na confecção dos calçados, mas só com a máquina de costura o sapato passou a ser mais acessível. As fivelas, em diversos usos, são partes importantes do sapato, desde a questão funcional de um fecho, como simplesmente enfeitar um modelo. A partir da quarta década, novos materiais, técnicas e tecidos entram na produção, que passa a ser setorizada entre design, modelagem, confecção, distribuição, entre outros setores, mudanças como a troca do couro pela borracha e pelos materiais sintéticos principalmente nos calçados femininos e infantis. O pé, até início do século XX, era considerado símbolo de castidade, uma parte do corpo mais tentadora que os seios, por isso deveriam ser protegidos dos olhares cobiçosos. A fabricação em massa só começou a partir de 1760, quando foi construída a primeira fábrica de sapato em Massachusetts, Estados Unidos. E até a metade do século XIX, os dois pés do sapato eram iguais. O primeiro par feito com pé direito e pé esquerdo apareceu entre1801 e 1822, na Filadélfia (CONDE, 2004). 
Figura 2: Sapato de pele de lagarto.

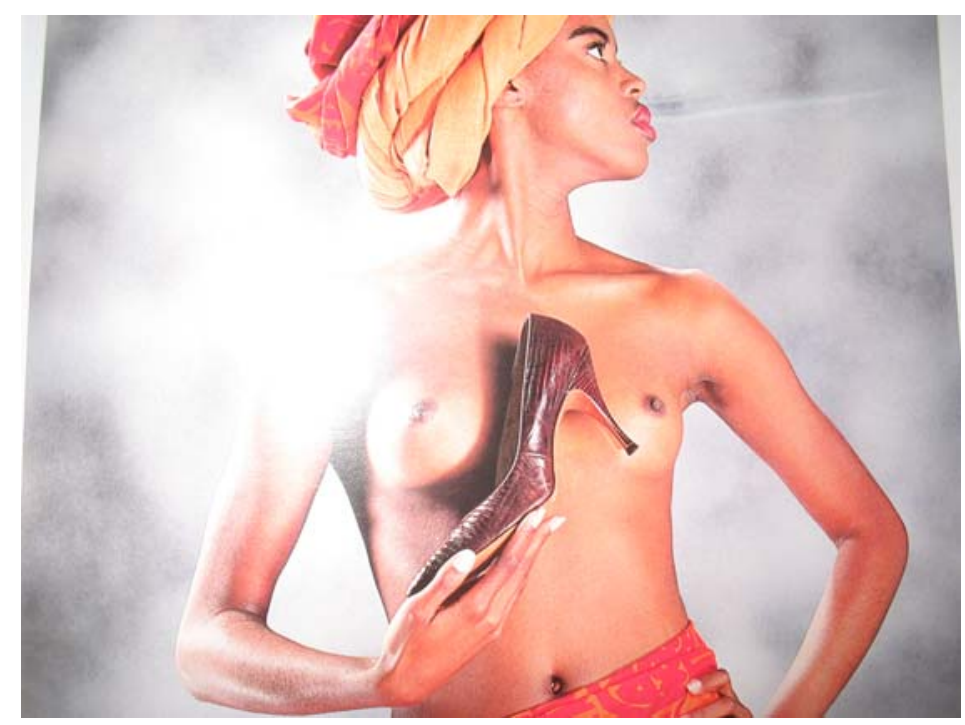

Fonte: CONDE, Linda. A história do sapato do século XX. São Paulo: Kling \& Associados, 2004, p. 77.

$\mathrm{Na}$ virada do século, aparecem os sapatos mais largos, confortáveis e resistentes para o trabalho, atendendo as necessidades de uma geração de mulheres com profissões liberais. Como materiais, surge a pele de crocodilo americano, outras peles de répteis, a camurça, o couro rússia - mais macio e leve, lona e borracha. As cores também acompanham as mudanças: marrom eduardiano, amarelos, esbranquiçados e avermelhados para os homens; e as botas na cor preta ou tan (caramelo), e lona clara e camurça colorida nos sapatos femininos. O estilo é o balmoral, laçadas na frente ou abotoadas na lateral e modelo chelsea para homens. Salto alto carretel para os sapatos femininos (Idem).

Em 1910, as pontas dos sapatos se arredondam. Os materiais utilizados são: couro de cabra, vaca, antílope, cetim, veludo ou camurça. Com a Primeira Guerra Mundial, a industrialização dá o seu salto, particularmente a dos sapatos. Os modelos utilizados são: courts; tango shoes; bars com todas as suas variações (MUSEU DO CALÇADO, 2006; CONDE, 2004).

Os anos 20 apresentam uma variedade de cores que cria o hábito entre as mulheres de combinar a cor do vestuário com os sapatos. O comprimento das saias sobe, e com isso a valorização do sapato. Tomam o 
lugar das botas, sapatos leves cada vez mais abertos. Os modelos bars e os courts, oxford e d'orsey.. Os tons vão do areia, bege, marrom, cinza, prata, dourado, veludos, peles etc. O crepe de borracha ganha lugar nas solas. As saias mais curtas, menos justas e confortáveis. As pontas voltam a afinar tanto dos sapatos masculinos quanto dos femininos (CONDE, 2004).

O marco da década de 30 com o surgimento dos open-toes pontas abertas transparecendo os dedos; open-heels - saltos altos e largos recortes no calcanhar. Carmen Miranda lança o Weges, em sapatos e sandálias prenunciando as plataformas. Nos sapatos masculinos as pontas são arredondadas e as pontas quadradas conforme figura abaixo (Idem).

Figura 3: Salto Plataforma

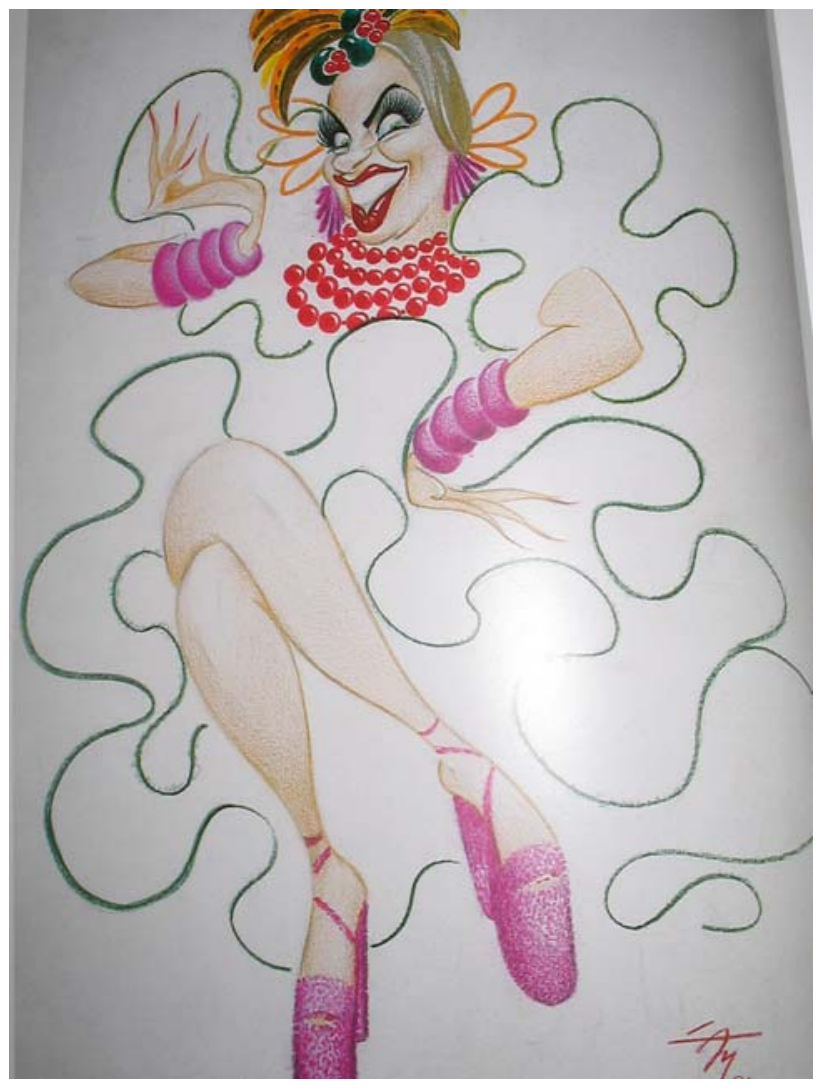

Fonte: CONDE, Linda. A história do sapato do século XX. São Paulo: Kling \& Associados, 2004, p. 50.

A partir dos anos 40 do século XX grandes mudanças começaram a acontecer nas indústrias calçadistas devido à recessão provocada pela Segunda Guerra Mundial, como a troca do couro pela borracha e pelos materiais sintéticos principalmente nos calçados femininos e infantis. Nessa 
década aparece o zíper. Como materiais surgem os sapatos de: lã, gabardine, linho ou crochê. As cores saem dos tons tradicionais: vão dos tons de azul, vinho e bicolores nos pés femininos e masculinos.

Figura 4: Sandália de plástico

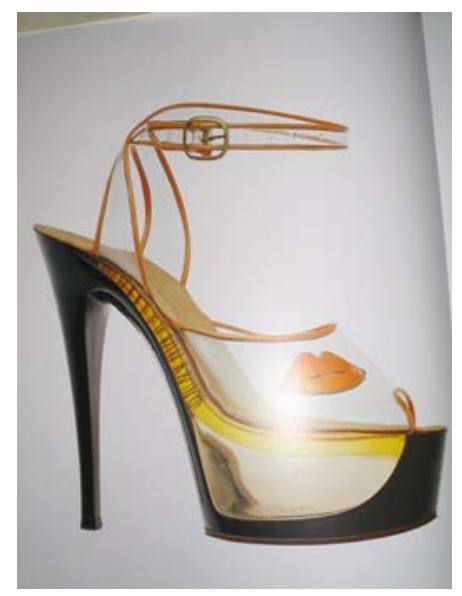

Fonte: CONDE, Linda. A história do sapato do século XX. São Paulo: Kling \& Associados, 2004, p. 98.

Nos anos 50, o design dos sapatos mostra formas agudas, sapatos pontudos, saltos altos e finos, pés arqueados. Acaba a escassez de material.

Reconhecida como a década dos Beathes e dos Rolling Stones, os anos 60, apresenta estilos com botas chelsea, de couro ou camurça, salto cubano e elástico nas laterais. Para mulheres, botas de diversos modelos como, por exemplo, o wet look - verniz brilhante, macio e impermeável.

O estilo psicodélico surge na década de 70 , com cores, plataformas, arco-íris, estrelas, nuvens flores aplicados ou bordados. 
Figura 5: Sandália com wedges-soles de madeira pintada de branco.

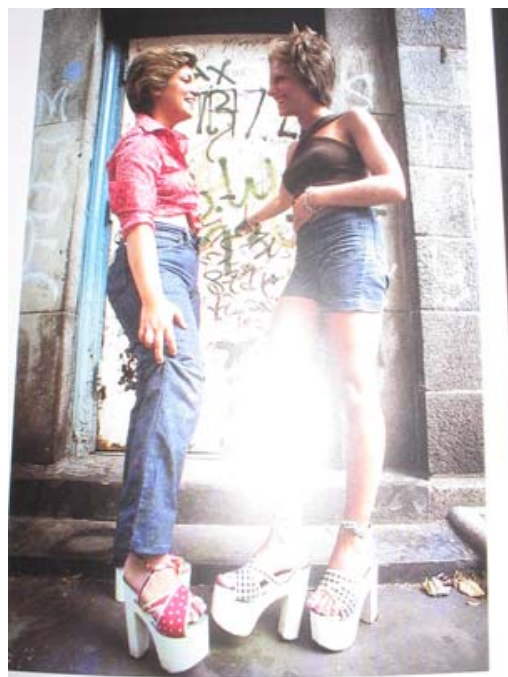

Fonte: CONDE, Linda. A história do sapato do século XX. São Paulo: Kling \& Associados, 2004, p. 101.

Nos anos 80, os tênis ganham o gosto popular, sendo considerado o calçado universal. Também ganham terreno os materiais sintéticos - plástico com cores berrantes. O Dockside e o Timberland ganham popularidade. No início dos anos 90, a plataforma e o salto vírgula voltam ao uso. A relação das griffes apresenta estilo clean em camurça ou veludo. Os artesãos usam a imaginação e criatividade (CONDE, 2004).

Figura 6: Timberland

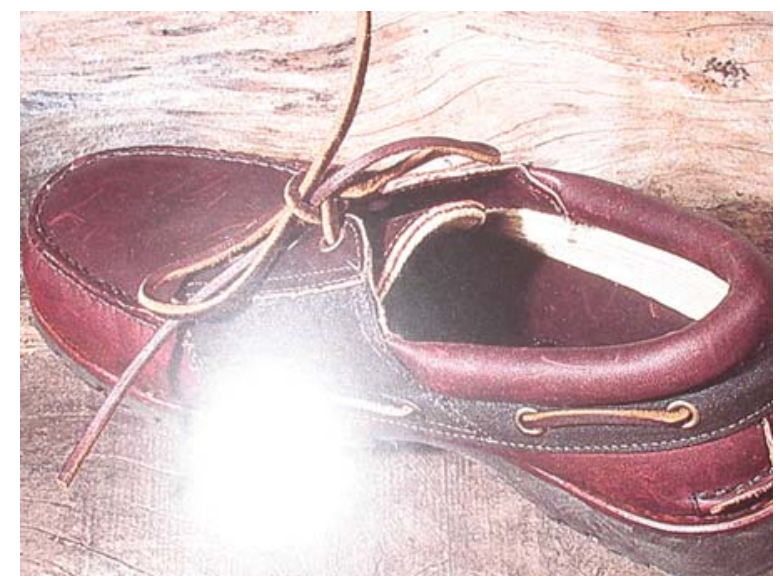

Fonte: CONDE, Linda. A história do sapato do século XX. São Paulo: Kling \& Associados, 2004, p. 121. 
$\mathrm{Na}$ moderna indústria o processo é quebrado em várias e distintas etapas como:

$>$ modelagem: criação, elaboração e acompanhamento dos modelos no processo de fabricação;

$>$ almoxarifado: recebimento, armazenamento, classificação e controle do couro e demais materiais;

$>$ corte: operação de corte das diferentes peças que compõem o cabedal (parte superior do calçado). No corte são utilizadas lâminas e facas especiais e/ou superior do calçado). No corte são utilizadas lâminas e facas especiais e/ou balancins de corte que pressionam os moldes metálicos na superfície do couro e/ou outros materiais;

> chanfração: preparação do couro para receber a costura;

$>$ costura: junção das partes que compõem o cabedal;

> pré-fabricado: fabricação de solas, saltos e palmilhas. Muitas empresas não têm esse setor, pois existem fábricas que se especializam na produção desses materiais;

> distribuição: controla o volume da produção, revisa a qualidade dos materiais e os distribui para os setores de montagem e acabamento;

> montagem: conjunto de operações que unem o cabedal ao solado;

$>$ acabamento: operações finais ligadas à apresentação do calçado como o escovamento, a pintura e a limpeza;

$>$ montagem e acabamento: em muitas empresas esses dois setores são organizados em linha de montagem, isto é, os postos de trabalho são colocados em linha e o produto em elaboração vai incorporando as operações parciais de cada trabalhador, até que, no final da linha, o produto resulta acabado;

> expedição: embalagem, encaixotamento e envio ao mercado de destino. 
Figura 7: Tradicional Mocassim

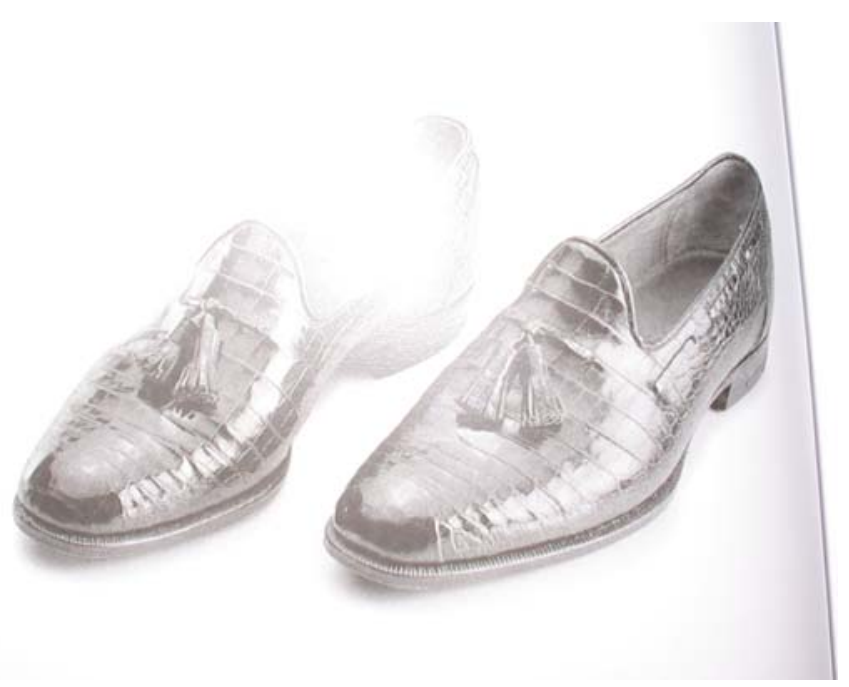

Fonte: CONDE, Linda. A história do sapato do século XX. São Paulo: Kling \& Associados, 2004, p. 131.

A necessidade dos atletas obterem um melhor desempenho em competições originou um novo segmento na indústria, voltado aos esportes, o que possibilitou a criação de tênis tecnológicos, que invadiram o vestuário de todos os grupos sociais. Além disso, a explosão da moda entre o público médio, a partir dos anos 80, também possibilitou o aumento do número de pessoas que passaram a consumirem calçados de grife, tanto os mais simples quanto aqueles assinados por grandes estilistas - verdadeiros artigos de luxo. 
Figura 8: A onda dos tênis.

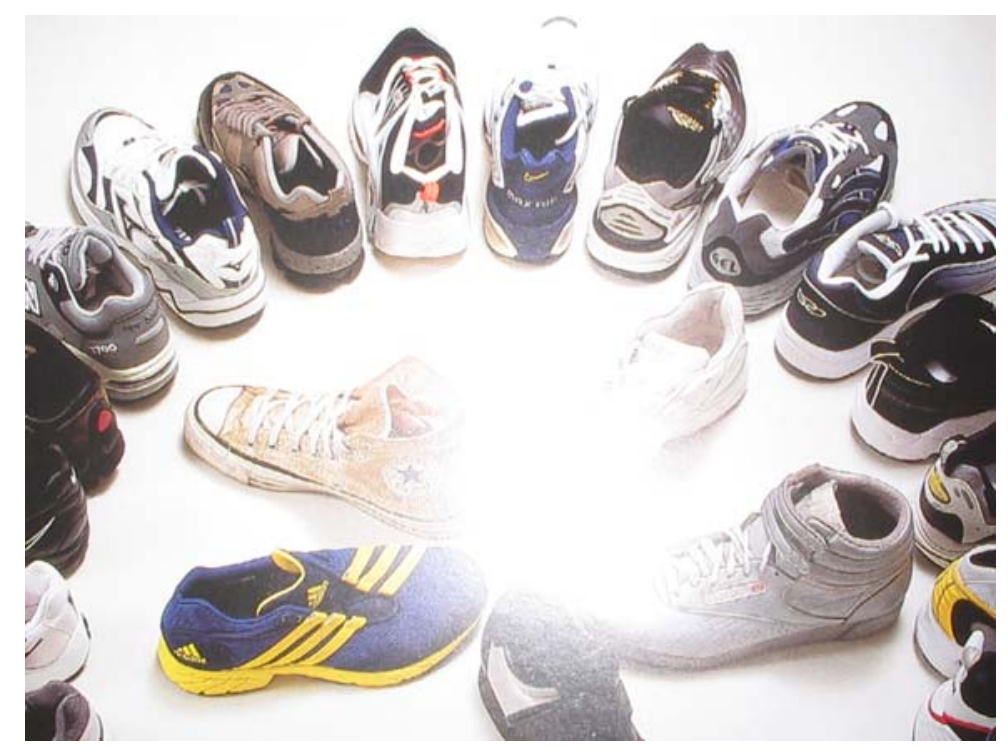

Fonte: CONDE, Linda. A história do sapato do século XX. São Paulo: Kling \& Associados, 2004, p. 118.

\subsubsection{O Salto}

Esta foi uma inovação capital, uma reviravolta decisiva na história da sapataria. Em sua origem o salto não era senão uma extravagância a mais. Não tinha, no fundo, outro objetivo a não ser o de compensar os elegantes do sofrimento do sapato de pontas alongadas. Forma, posição, altura, fornece ainda agora pretexto e variações sobre os temas propostos pela moda. O salto tornou-se parte integrante do calçado. Sua aparição pode ser explicada pela: vaidade humana; necessidade de se distinguir através de uma singularidade no trajar ou ainda para se colocar acima da plebe, ou simplesmente para parecer mais alto. 
Figura 9: Sapato de Camurça.

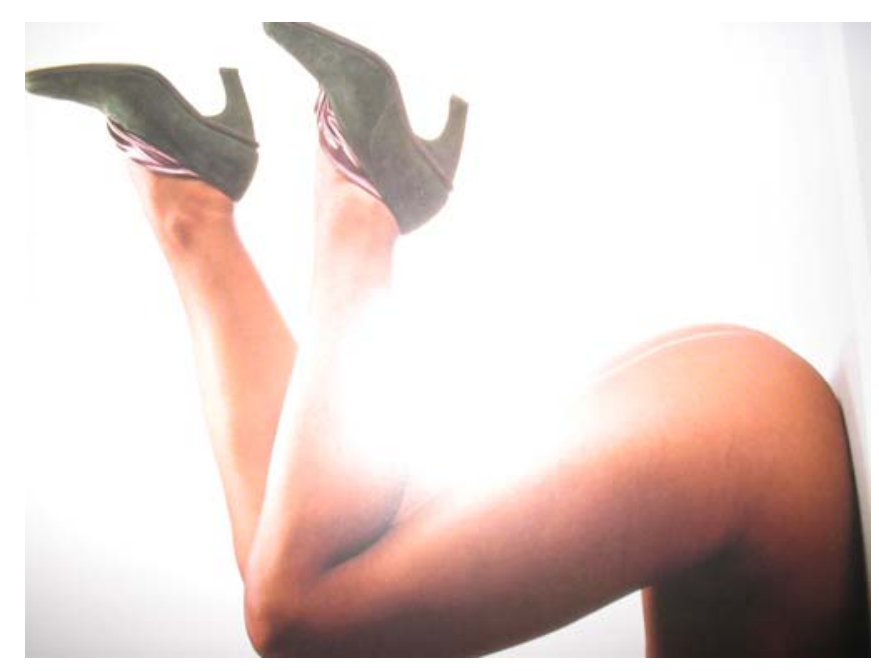

Fonte: CONDE, Linda. A história do sapato do século XX. São Paulo: Kling \& Associados, 2004, p. 131.

\subsubsection{Artesanato à Indústria}

O costume de retomar as formas outrora em voga para modificar e adaptar às exigências novas tornou-se, na indústria governada pela moda, parte integrante da criação artística. De fato, em uma fábrica moderna os "criadores" dispõem de uma coleção de calçados de todas as épocas e de todos os países para se documentarem. A diversidade espantosa das formas e dos desenhos que regem a moda obriga a indústria a criar uma coleção de modelos. A isso obrigada também pelas rápidas mudanças do gosto público e à imperiosa necessidade de produzir sem interrupção.

\subsubsection{As Influências dos Sapatos}

No mundo do showbusiness, cinema, arte, política, enfim, em todas as áreas humanas, o sapato revela status, atitudes, preferências sexuais, valores artísticos e estéticos.

Além de status, os sapatos expressam o estilo sexual de mulheres: agressiva e ativa; romântica e submissa; misteriosa e sofisticada; descontraída e divertida. As relações que se estabelecem entre o sapato e seus vários significados, além da beleza das cores e formas. Por milhares de 
anos os homens têm na sua forma de vestir uma maneira de se comunicar. Esta comunicação se faz através de uma linguagem cheia de símbolos e significados através dos tempos e das várias culturas. Pés e sapatos estão há milênios misticamente ligados como na cultura chinesa, a qual cultuava o pé atrofiando-os propositalmente em nome da beleza (CONDE, 2004).

Os pés estão diretamente ligados à sexualidade para os chineses, que durante séculos enfaixaram os de suas mulheres, para torná-los pequenos, adornando-os com delicadas sapatilhas. Estas sapatilhas traziam ricos bordados, inclusive na sola que, claro, não eram feitas para andar, apenas para enfeitar.

Depois do espartilho, são os sapatos e botinhas de verniz preto e salto stiletto que fazem mais sucesso na cultura sadomasoquista.

Figura 10: Salto Stiletto

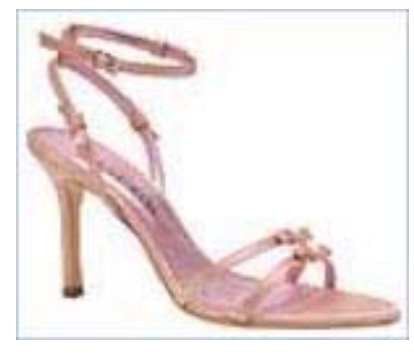

Fonte: Museu Virtual do Calçado, 2006.

O stiletto está ligado ao fetiche. Este modelo de calçado é mais para o homem do que para a mulher. A mulher que usa estes saltos está exercitando o seu poder de sedução.

A plataforma revela a personalidade de uma pessoa que se diverte como Carmen Miranda, exemplo máximo da plataforma. Sensual, e com approach irreverente.

As sandálias japonesas altas ou rasas são símbolos de feminilidade. Uma das fantasias das meninas é usar salto quando se tornarem mulheres. 
Figura 11: Sandálias Japonesas

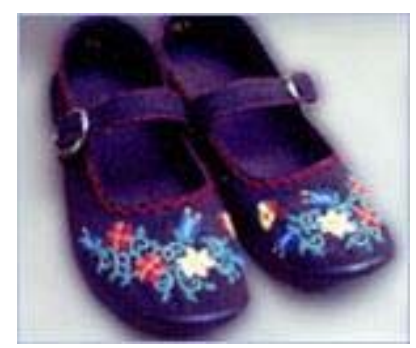

Fonte: Museu Virtual do Calçado, 2006.

O mundo dos calçados carrega muitas excentricidades, como por exemplo, na Europa dos séculos XVII e XVIII, usar saltos vermelhos era símbolo de status permitidos somente aos nobres. Na corte de Luís XIV os homens usavam sapatos de saltos que reproduziam pinturas de rústicas miniaturas ou cenas românticas. Desde Portugal, Maria Antonieta tinha um serviçal somente para cuidar de seus 500 sapatos, que eram catalogados por data, cor e estilo. Nos casamentos de tradição anglo-saxão, o pai da noiva dá ao noivo um par de sapatos da filha, simbolizando a transferência de autoridade. No Brasil os índios impermeabilizaram a sola dos pés mergulhando-os em látex. Botas longas foram usadas pela primeira vez por piratas e contrabandistas que costumavam esconder o roubo dentro delas.

A virada do milênio traz como desafio a pesquisa direcionada em como utilizar a tecnologia em beneficio da empresa e conquistar vantagem competitiva. Os criadores de moda predizem a volta do naturismo, da simplicidade, do purismo e do individualismo com exóticas influências étnicas (CONDE, 2004, p. 142). 


\subsection{A MODA NO CONTEXTO SOCIAL}

Justifica-se Moda por ser esta uma forma do homem expressar seus sentimentos de forma criativa, moldando-se ao panorama étnico, cultural, social e econômico do ambiente em que está inserido. Através da forma de vestimenta é possível contar a história da evolução da sociedade e interpretar o seu comportamento.

A moda possui um caráter feminino. Constitui a maneira específica dos ocidentais apresentarem o seu vestuário.

Para Lipovetsky (1987) a moda marca seu surgimento no final da idade média. Só a partir do final da idade média é possível reconhecer a ordem própria da moda, a moda como sistema, com suas metarmofoses incessantes, seus movimentos bruscos, suas extravagâncias. A renovação das formas se torna um valor mundano, a fantasia exibe seus artifícios e seus exageros na alta sociedade, a inconstância em matéria de formas e ornamentações já não é exceção, mas regra permanente: a moda nasceu.

No final da idade média a moda estava solidificada na corte dos reis. A mudança periódica na forma de vestir era marcada apenas na camada social dominante.

Neste período, o homem e a mulher eram igualmente ornamentados, até competindo entre si. A diferenciação era presenciada na construção visual de cada sexo, mas ambas apresentavam riqueza em detalhes, presente na aristocracia européia. Com a consolidação da burguesia, tem início o caráter feminino da moda. Os homens passam a se preocupar mais com a carreira e desviam os interesses masculinos da moda, que passa a ser característica das

mulheres que exibiam na vestimenta o status e o prestígio do marido. Roupa funcional e liberdade de movimentos eram atributos do vestuário masculino, enquanto a rigidez e a suntuosidade da roupa feminina serviam para exprimir o poder e a riqueza do marido (SOUZA, 2005, p. 22).

O homem trabalha, neste período, para proporcionar à sua esposa e filhas a suntuosidade na vestimenta. A produção também confere 0 caráter feminino à moda pela relação profissional com as costureiras, bordadeiras, vendedoras, maquiadores, tecelãs, modelos etc.

A moda apresenta atributos femininos devido aos fatos históricos; frio pela forma que julga as pessoas pela aparência visual do que está trajando 
e fútil pela necessidade de mudança constante e busca de novidades. A escolha do traje de vestimenta mostra: o que, onde, quem e como as pessoas colocam-se frente à sociedade, aos seus grupos de referência e a si mesmos. Constitui um código simbólico aberto, onde o significado é dado, a priori, pelos produtores do setor para o seu consumidor. Ela não é imposta, ocorre uma dinâmica entre produtor-produto-consumidor. O produtor faz um símbolo que trabalha de forma aberta, dando e sugerindo interpretações para o significado produzido, e não determinando de forma inabalável. O consumidor toma posse dessa produção e dá sua interpretação do significado com o propósito de encontrar o signo ideal para o que quer manifestar e/ou ostentar (SANT'ANNA, 2002; NASCIMENTO, 1972, p. 14).

O século $X X$ apresenta a moda da forma que conhecemos: com espírito capitalista. Tem o caráter da efemeridade, da mudança constante, da ostentação de poder e riqueza explorando na formação de segmentos de consumidores. Da mesma forma que as pessoas buscam a individualidade, querem também ser identificados por alguns grupos. Estes possuem os seus signos de status, beleza, costumes, atitudes e posturas frente à sociedade. A roupa é peça fundamental para compor a identidade desses grupos. Para ser aceita, a pessoa deve saber construir através do vestuário, a composição correta dos signos que envolvem o grupo específico que pertence ou que quer pertencer.

Os grupos manipulam seus signos da forma como desejam se comunicar com a sociedade. A indústria da moda decodifica esses signos, modela e estiliza a identidade proposta e lançam no mercado. O grupo entende a mensagem e compra a roupa. Os grupos que consomem determinados estilistas compram identidades prontas. Manter atualizado significa ser compreendido pelos iniciados da linguagem - editores e jornalistas de moda. Criar em moda significa dar uma nova abordagem para os elementos já existentes de maneira que seduza tanto os produtores quanto o público-alvo.

O estudo da moda apresenta a compreensão do passado e do presente. A análise permite o discernimento da relação entre a identidade de grupo e a do indivíduo: o vestuário como instrumento de identificação e de auto-afirmação frente ao grupo que o mesmo pertence ou projeta pertencer. 
A moda é uma ação simbólica onde os grupos apresentam-se para a sociedade. Constitui uma linguagem proporcionando uma comunicação muda, mas rica em detalhes. Dois aspectos da moda mostram uma forma de compreender a sociedade: os dados de leitura presentes nas roupas, os acessórios, o comportamento das pessoas e a análise do gestual. Nesta ação estão sendo afirmados ou negados: o gênero, o grupo ao qual o indivíduo deseja pertencer, o poder, o status, a profissão etc. Em segundo lugar, a busca pela mudança, renovação e novidade, apresentada a cada estação do ano. A novidade anunciada é, na maioria das vezes, uma variação do que já foi feito no ano anterior. Todos os produtos que o indivíduo consome passam pelo crivo do que é considerado certo ou errado para estar na moda.

A aparência construída pelo indivíduo é uma auto-representação. Diariamente são tomadas decisões sobre o status e o papel social das pessoas, baseados no que elas estão vestindo: tratam suas roupas como 'hieróglifos sociais', que escondem, mesmo quando comunica, a posição social daquilo que a vestem. A moda e a indumentária podem ser as formas mais significativas nas quais são construídas, experimentadas e compreendidas as relações sociais entre as pessoas. As coisas que as pessoas vestem dão forma e cor às distinções e desigualdades.

Para compreender todo esse processo, fazse necessário citar uma mudança que possibilitou à população brasileira, a popularização das compras e o real sentido da moda marcado pelo aparecimento da sociedade do consumo que surge com 0 desenvolvimento e a internacionalização da industrialização. Neste período crescem as exportações e os coeficientes das importações. Com o incremento na produção de bens de luxo e de capital, ocorre a demanda por aquisição de maquinários e de importação de matérias-primas. Como conseqüência há o aumento da necessidade da exportação para sustentar 0 que este desenvolvimento exige o que acarreta a dívida externa do país. É visível o crescimento do país na produtividade e no lucro. Há um alto crescimento vegetativo da força de trabalho urbano e migrações internas. O salário se mantém baixo. A ausência de organização sindical favorece o acúmulo de capital privado e aumenta o poder político da burguesia. $\mathrm{O}$ mercado industrial torna-se fortemente oligopolizado 
e com forte preponderância de multinacionais (BARNARD, 2003, p. 24).

O processo de desenvolvimento ressalta as contradições, embora com alto crescimento econômico, acentua-se a pauperização dos trabalhadores. A indústria apresenta contrastes na produção: os bens de luxo são manufaturados com alta tecnologia e para os bens de subsistência são utilizados métodos obsoletos. O desenvolvimento da industrialização do Brasil promove o "subdesenvolvimento", pois continua a transferir os seus excedentes aos países de primeiro mundo através da troca desigual ou de pagamento de juros.

Surge um novo segmento social constituído por administradores, técnicos e profissionais liberais, que junto à burguesia apresentam-se como públicos em potencial de consumo de bens de luxo. O fortalecimento do sistema capitalista tem como objetivo reproduzir na periferia os padrões de consumo dos segmentos mais favorecidos. No Brasil, a sociedade de consumo se estrutura através de bolsões de consumo que se localizam nas regiões sul e sudeste. De acordo com Pietrocolla (PIETROCOLLA, 1987, p.22-24):

O subdesenvolvimento aparece como reflexo de uma sociedade em que a minoria dominante e modernizada reproduz os padrões de consumo de primeiro mundo, adotando sua ideologia e tecnologia, enquanto a maioria da sua população é mantida marginalizada do processo de desenvolvimento, vivendo em condições de extrema pobreza e recebendo salários que mal dão para sobreviver (Idem).

O mito é considerado a capacidade do homem de criar um mundo de significados. É uma fala, um discurso, uma linguagem que expressa coisas do mundo, as contradições, as inquietações do homem. Na sociedade de consumo um dos mitos mais sagrados é o da juventude.

A definição de jovem é ser belo, forte, feliz e transformador. É saber lidar com o inesperado com rapidez, é não ter marcas deixadas pelo viver. É ter a liberdade idealizada e um poder ilimitado. Ser jovem é ter dentes bonitos e limpos, pele queimada de sol, lábios sorridentes, cabelos revoltos e movimentos ágeis. É antes de tudo ser livre, poder escolher e mudar a vontade uma vez que seu caminho está ainda por ser traçado. Seu tempo é o futuro, impalpável, distante e promissor (Idem). 
Assim, a cultura de massa desagrega os valores gerontocráticos e acentua a desvalorização da velhice, dá forma à promoção dos valores juvenis, assimila uma parte das experiências adolescentes. Sociologicamente, ela contribui para o rejuvenescimento da sociedade. Antropológicamente, ela verifica a lei do retardamento contínuo, prolongando a infância e a juventude junto ao adulto. Metafisicamente, ela é um protesto ilimitado contra o mal irremediável da velhice (MORIN, 1969).

Esses valores conotativos do jovem, nas sociedades capitalistas sugerem mudança e renovação das mercadorias, ou seja, comprar novos objetos, novas roupas expressam comportamento de pessoas que não têm medo de mudança. Ser jovem é mudar muito e sempre, experimentar as emoções, o que significa estar aberto ao mundo e ao consumo, aberto às novidades que o mercado apresenta, de futilidades a bens realmente importantes. É se emocionar com o poder da compra, da aquisição, que também garante o status e integração social dentro do grupo de referência.

A ideologia do consumo consiste na transfiguração dos bens eminentes em vitais, entendendo por estes, tudo o que torna o homem identificado com o seu meio e no seu tempo.

O mito da juventude responde ao desejo dos homens de serem eternamente jovens, belos e felizes em uma sociedade supostamente homogênea, onde reina a igualdade e a liberdade. Essa imagem mítica criada pela sociedade acoberta a grande diferença de classes que determinam as reais condições de vida de cada um. $O$ mito da juventude nunca remete o jovem ao mundo real, das condições de vida, do trabalho, das diferenças sociais, nivelando todos igualmente, como consumidores, destacando seu papel importante na reafirmação e reatualização da crença no consumo como um modo de vida. Existe uma lacuna entre as condições reais do jovem em relação a imagem veiculada pela mídia de massa, que pode ser preenchida pelas fantasias da propaganda e pelo consumo (BARNARD, 2003).

A crescente anuência em massa dos homens à lógica do capital assumiu, nos últimos anos, uma dimensão transnacional. As 
atuais exigências de integração e inserção mundial apresentam as inovações tecnológicas e os recursos da mídia como imprescindíveis na economia. Os produtos são manufaturados em qualquer parte do mundo não apenas para serem consumidos pelo seu valor de utilidade funcional, mas também traduzir um novo estilo de vida, onde se reconhecem e se diferenciam a partir das imagens e marcas desses produtos, ocorrendo assim uma intensificação nos processos de idolatria dos objetos de consumo que, orientam condutas e referências de um grupo cultural.

\begin{abstract}
Itens de moda e indumentária são vistos como armas e defesas. Moda e indumentária podem ser entendidas como armas de ataque e defesas utilizadas pelos diferentes grupos que vão formar uma ordem social, uma hierarquia social, alcançando, desafiando ou sustentando posições de dominação e supremacia (DOUGLAS apud BARNARD, 2003, p. 67).
\end{abstract}

Esse advento da globalização, cujas causas nos remeteriam aos séculos XV-XVII com a expansão do capitalismo têm como marco histórico significativo o advento das sociedades urbanos-industriais e a modernização do século XIX, os quais substituíram, paulatinamente, os vínculos sociais baseados em tradições locais pela lógica do mercado, deixando os indivíduos perdidos em meio ao anonimato e complexidade dos novos códigos das grandes metrópoles (SEVERIANO, 2001).

Devido a todas essas mudanças, as instituições sentem-se pressionadas tanto pela competitividade quanto pelo seu discurso de satisfação máxima aos desejos e necessidades do consumidor. Para agradar ao seu público, que se transforma em velocidade bastante rápida, a prática da propaganda trabalha o estilo e a marca da moda integrada ao contexto estratégico, otimizando a administração das organizações do setor da moda (BRAGA, 1977, p. 9-10)

.Existe nas organizações uma dificuldade em compreender os conceitos e definições, e principalmente a sua implementação de forma integrada, com representatividade em tempo real. As intenções de obtenção de vantagem competitiva, agregando valor ao produto oferecido ao cliente, não são viabilizados devido à dificuldade de compreender os novos conceitos do contexto macro de "o que" e "como" fazer para atender aos anseios dos grupos. 
Duas tendências sociais são essenciais para o estabelecimento da moda e caso uma delas esteja ausente ou falte numa sociedade, a moda não se formará. A primeira dessas tendências é a necessidade de união, a segunda, o anseio pelo isolamento: os indivíduos devem possuir o desejo de ser único, e de serem considerados como separados do todo maior (SIMMEL apud BARNARD, 2003, p.28).

Para o sociólogo Braga, a moda em geral é uma das máscaras usadas pelos atores sociais para facilitar a comunicação de ordem grupal. Representa status, profissão ou situação social. A moda é a uniformização do indivíduo. Os jovens procuram na moda uma forma de se comunicar, através de códigos simbólicos das cores, padrões e estilos. O exagero utilizado revela a necessidade do segmento em criar novas estruturas psicossociais adequadas a uma sociedade de informação. Braga considera impossível fazerse uma moda exclusivamente brasileira, devido à influência da comunicação de massa. Acredita que nenhum país possui autonomia cultural para impor seu tipo de traje. Os desenhos dos vestuários são uma expressão de uma civilização e representa suas facetas, suas contradições e necessidades de manifestação exterior. Como os parâmetros da igreja, a roupa do homem da rua é uma forma ritualística de apresentar um status, uma posição ideológica e valores individuais à sociedade comum em que vive (1972, p. 9-10).

A cultura capitalista moderna assumiu, principalmente nas últimas décadas, uma preocupação acentuada com a realização individual privada em estreita ligação com as opções do consumidor, como: a beleza, a juventude e a felicidade. O sucesso pessoal é cada vez mais explorado pela indústria cultural como conversora de bens a serem adquiridos através no consumo. Uma acentuada gama de novos produtos passa a ser oferecido a grupos de consumidores cada vez mais segmentados. Os indivíduos passam a buscar soluções individualizadas, encontrando no apelo publicitário o prazer no consumo. Ocorre a ação das empresas privilegiando o exclusivo, que é referendado como exercício das preferências do consumidor.

Os adolescentes ainda são suficientemente jovens para serem dominados pela imagem, com toda a bajulação da propaganda, marketing de identidade, mensagens pela mídia, tendências e rótulos. Eles ainda acreditam no poder de uma marca de conferir status, serenidade, carisma e conhecimento. Eles 
constroem suas identidades pelas compras que fazem (UNDERHILL, 1999, p. 139).

Para o adulto e adolescente, a moda constitui uma forma de participação social. A insegurança nos adolescentes é explicada como fenômeno do ocidente onde o jovem sofre restrição pelo meio social em que vive que acarreta uma demanda pela aproximação de um grupo de referência. A escolha do grupo de referência depende da necessidade do adolescente, se for uma carência afetiva vai identificar-se com o ídolo musical ou outra celebridade da televisão ou cinema. A partir daí surge à imitação de suas roupas, gestos, ações e linguagem. O jovem projeta-se nos seus ídolos e a adoção por modelos aspiracionais estrangeiros gera maior prestígio junto ao seu grupo de influência. A necessidade por prestígio supera as próprias exigências climáticas do ambiente. É comum presenciarmos estilos que não condizem com a estação do ano, mas sua utilização é justificada pela necessidade de se sobressair que gera o prestígio. As cores apresentam um simbolismo cultural e pessoal, como por exemplo, a adoção do preto como luto no ocidente, enquanto que no oriente a cor adotada é o branco. O gosto pessoal sempre influi na adoção das cores. Por mais que a moda dite uma determinada cor para a estação, se a pessoa tem uma prevenção contra a mesma, não a usará. Os sistemas de comunicação de massa não vão criar uma padronização da moda, mas sim a divulgação de todos os estilos que a compõem (CARVALHO, 1972, p. 8).

A mensagem simbólica, codificada, continuará ajudando a persuadir o mercado consumidor, particularmente em relação à moda masculina e feminina.

Eco e Danesi (2002) identificam três níveis de codificação publicitária, dentre os quais ele chama de nível iconográfico ou histórico, cujas configurações remetem a significados convencionados.

Morin (1969) considera a juventude como uma categoria social, pois os objetos da cultura de massa tendem a uniformizar o comportamento da humanidade através de símbolos da comunicação como a moda. A moda exige simbolismo e codificação na sua mensagem que, em última análise, vem gratificar homem e mulher, atribuindo-lhe afirmação de prestígio e superioridade. 
O problema da mensagem publicitária, voltado para a moda, constitui-se como um sistema conotativo. Se a moda exige simbolismo e codificação na sua mensagem, a linguagem da publicidade exige um determinado grau de iconicidade que remete a um mundo de signos particularizado por sua realidade social. A publicidade e a moda, em certos níveis conotativos, oferecem perspectivas criativas que se completam (CASTRO, 1972, p. 16-18).

Os meios de comunicação de massa, controlados economicamente pelo capitalismo, estão sempre dispostos em divulgar imagens e mensagens dos modismos importados.

Do ponto de vista econômico, a moda jovem é simplesmente um problema de industrialização, com objetivos claros: importar e diluir o exótico, mantendo um falso status cultural/social, diferente da realidade brasileira que luta pelo mercado têxtil, livre dos grandes trustes internacionais.

As agências de publicidade continuam moldando o bom gosto do público, tornando a moda uma necessidade consumida e consumada. McLuhan explica que, da mesma maneira que as canções, filmes e diversões de sucesso, a moda atropela para ocupar o vácuo criado pelos deslocamentos tecnológicos. O que existe é toda uma herança sociocultural que recebemos da matriz, desde a colonização portuguesa até os dias atuais, quando os meios de comunicação de massa controlam o gosto do público, fazendo crer que o "belo" é sempre trazido dos países desenvolvidos (MCLUHAN, 1969).

Pignatari (2002) afirma: o único luxo que podemos permitir-nos é o de criar, inovar, mesmo ao preço de um talvez inevitável estágio imitativo. E quanto mais os meios de comunicação se multiplicam, mais o consumidor torna-se vítima, sem defesa ou opção para usar e vestir o que desejar. A moda deixou de interessar somente aos especialistas, constituindo-se hoje um problema analisado e debatido por sociólogos, psicanalistas, etnólogos e estudiosos em comunicação.

O gosto pela simples novidade de consumo, jogado à cara do consumidor, é vista por Barthes: o real essencial da moda é a sua realidade econômica, comercial e social, que se assenta sobre a necessidade de fazer vender a roupa de modo mais rápido do que o uso. Para obter essa aceleração, que não é natural, pois já houve sociedade sem moda, surge a 
obrigação de se impor o arbitrário da moda. Esta é decidida por um grupo, que a lança de maneira arbitrária. Dá-se então, a partir daí, uma inversão mitológica, uma vez que o jornal ou a revista especializada transforma o arbitrário em necessidade, em imperativo. A visão Barthes serve para definir a imposição da propaganda ao consumidor de moda nos países capitalistas, uma vez que a sociedade de consumo num país socialista difere totalmente do exemplo bartheseano (BARTHES; MOSCA, 1979).

A moda jovem nos países subdesenvolvidos é, portanto um influente agente de mistificação social que convence as pessoas a viverem preocupadas com as "últimas novidades do consumo", promovidas sem a mínima visão crítica (CARVALHO, 1972, p. 8)

A comunicação corre o risco de converter-se numa técnica de recursos gigantescos destinada à promoção e à perpetuação dos objetos e símbolos da sociedade de consumo ocidental. Nesse sentido, o interesse das agências de publicidade em formar uma massa de consumidores, objetos de promoções e lançamentos publicitários dos mais ridículos para a nossa realidade cultural/social, é mistificar e mitificar. O que os mitos e ídolos usam é reproduzido com tanta freqüência nas revistas e televisão, que passa a ser produto de consumo, principalmente para a juventude, alheia aos problemas econômicos de nossa realidade. A moda jovem só terá - nos países subdesenvolvidos - uma função de integração social, quando livre da máquina publicitária capitalista, for criada e/ou inventada por programadores visuais ligados a movimentos de vanguarda, que trabalhem numa indústria têxtil nacional. Por enquanto, a moda é um psicodelismo inútil, uma festa colorida, de personagens sem função no contexto sociocultural brasileiro (VARELA, 1972, p.21-26).

$\mathrm{Na}$ indústria da moda há o mito da qualidade da moda e o da própria moda em si, como algo etéreo, indefinido, além da imaginação humana. O mito da qualidade se fez necessário e a publicidade nasceu justamente para decantá-lo e aumentar o consumo e fabricação de um produto de uma marca em detrimento do mesmo produto de uma outra marca. O dispêndio confesso para fins de ostentação está mais visivelmente praticado em assuntos de vestuário do que qualquer outro setor de consumo. A maior parte do dispêndio em que incorrem todas as classes em questão de vestuário é principalmente 
devido ao interesse pela aparência respeitável, não pela proteção de sua própria pessoa. Vestir deixou de ser a proteção natural do corpo e passou a ser cada vez mais uma forma de estética.

Na moda, como na arte, o homem consome etiquetas por obras e os nomes passam a ter significados que vão além deles mesmos. A etiqueta na moda é que pode vender o produto mais que sua própria qualidade. O mito da qualidade supera a própria qualidade em si no vale-tudo do consumo (NASCIMENTO, 1972, p. 14)

A realidade da moda não passa de um capricho passageiro de uma coletividade que consumiu barbitúricas mensagens publicitárias em excesso. Suas oscilações, porém, dependem das oscilações dos valores sociais vigentes e quase sempre de inteligentes e bem planejados jogos comerciais, que dão dinheiro e fama a homens que entendem de seu 'metier'.

Segundo McLuhan (1969), talvez a moda seja uma espécie de macrogesticulação de uma cultura inteira tendo um diálogo ou encontro frontal com as suas tecnologias.

O mito é, para a moda, o que o lucro é para a economia dos países capitalistas: a própria sobrevivência. A moda não pode subsistir sem etiquetas e por mais que os sociólogos e psicólogos procurem definir o que ela é, como manifestação cultural do homem, não passará sempre de uma forma disfarçada ou indisfarçada do consumo do mito, fortalecendo o mito da estrutura e sendo fortalecida por outros mitos que a estrutura crie paralelamente.

$\mathrm{Na}$ moda, o mito coletivo aparece quando o jornal ou a revista especializada, através de sua fraseologia, de sua retórica, transforma as formas de moda em álibi, e em utilidade.

Os homens se sentem seguros com signos claros. O sentido de uma frase é dominado mais facilmente do que uma imagem e toda a construção de sistemas de signos é mais importante do que parece. A moda fala de seu objeto pela razão de ordem econômica. Calculista, a sociedade industrial está condenada a formar consumidores que não calculam. Se produtores e consumidores tivessem consciência idêntica, as vestimentas só seriam adquiridas na medida muito lenta, de seu uso. Para obnubilar a consciência contábil do comprador, é necessário estender diante do objeto, um 
véu de imagens, de razões, de sentido; elaborar em torno dele uma substância mediata, tipo aperitivo; criar um simulacro de objeto real, substituindo o tempo pesado do uso por um tempo soberano.

Segundo Morin (1969), o primeiro motor da moda, é, evidentemente, a necessidade de mudança em si mesma, da lassidão do já visto e da atração do novo. O segundo motor da moda é o desejo de originalidade pessoal por meio da afirmação dos sinais que identificam os pertencentes à elite. Esse desejo de originalidade, desde que a moda se espalhou transforma-se em seu contrário; o único, multiplicando-se, vira padrão. É então que a moda se renova aristocraticamente, enquanto se difunde democraticamente. A cultura de massa desempenha esse papel capital do aristocratismo: permite ao público imitar, o mais depressa possível, a elite; coloca-se a serviço da aderência identificativa por todos os meios.

Guerra apresenta em seu estudo um mapeamento do comportamento dos jovens brasileiros de 15 a 30 anos, das classes A, B e C, que vivem em cidades como São Paulo, Salvador, Porto Alegre, Brasília e Rio. Mostra que eles têm dificuldade em lidar com o excesso de informação no mundo moderno. Os jovens são, em sua maioria, vaidosos ao extremo, hedonistas, egoístas, egocêntricos, não acreditam em projetos coletivos, não são engajados, têm dificuldade de conviver com o futuro, de fazer plano e levam a busca pelo prazer imediato às últimas conseqüências. O jovem brasileiro está cada vez mais complexo. Não se limita mais a ser dividido em tribos simplistas. Parecem se mostrar cada vez menos preocupados com sexo seguro, evitar drogas e se engajar em projetos sociais. Os jovens têm dificuldade de lidar com o futuro. Levam a ética perigosa do hedonismo e do individualismo às últimas conseqüências. Têm grande dificuldade de lidar com a construção coletiva da vida. Estão esticando cada vez mais a adolescência, aprisionados em um futuro que não existe e estão vivendo cada vez mais velozmente, como se não houvesse um futuro possível, até o esgotamento, num ritmo frenético (GUERRA, 9 de maio de 2005).

Ao contrário do panorama global apresentado na mídia, a mensagem publicitária cria e mostra um mundo perfeito e ideal. Diariamente anúncios diversos são veiculados. O seu conteúdo tem muito pouco de informação do bem que anunciam, mas muitos apelos emocionais que geram 
necessidades e demandas no público-alvo. Não há como escapar, ignorar ou ficar alheio a uma das formas mais dinâmicas da comunicação da atualidade: as mensagens publicitárias. Os jovens ocupam espaço nas empresas de publicidade porque constituem um grupo cada vez maior de consumidores potenciais. A publicidade dirigida a esse segmento tem a intenção de criar uma identidade e um estilo de vida. Os jovens por sua vez, sentem-se mais seguros quando fazem parte de um grupo. Assim a publicidade busca manipular e ditar os hábitos de comportamento da juventude brasileira (CARVALHO, 2000).

A otimização do esforço de comunicação e as conseqüentes mudanças nas empresas constituem um tema relevante para o momento atual, onde as organizações objetivam expandir sua participação em mercados emergentes, como é o caso, do Brasil. 


\section{DESENVOLVMMENTO DAPEQUISA}




\subsection{ESTUDOS DE CASOS}

Estudos de casos constituem a estratégia preferida quando as questões "como" ou "por que" são colocadas, quando o investigador tem pouco controle sobre eventos, e quando o foco repousa em um fenômeno contemporâneo dentro de um contexto de vida real. Os estudos de casos "explanatórios" também podem ser complementados por dois outros tipos: exploratório e descritivo. Independente do tipo de estudos de casos, para superar as críticas tradicionais ao método (YIN, 1989, p. 13).

No estudo de casos, o pesquisador explora uma única entidade ou fenômeno (o caso) limitado pelo tempo e atividade (um programa, evento, processo, instituição, ou grupo social) e coleta informações detalhadas pelo uso de uma variedade de procedimentos de coleta de dados durante um certo período de tempo (Idem).

O desenvolvimento de projetos de pesquisa de estudo de casos é uma parte difícil de realizar, pois ainda não foram codificados. Coloquialmente, um projeto de pesquisa é um plano de ação de sair de um lugar e chegar a outro, onde "sair" pode ser definido como o conjunto inicial de questões a serem respondidas, e "chegar" é o conjunto de conclusões (respostas) em relação às perguntas. Entre o "sair" e o "chegar" pode-se encontrar várias etapas, incluindo a coleta e análise de dados relevantes. Nos projetos de estudos de casos há cinco componentes importantes: 1) questões do estudo; 2) proposições se houver; 3) unidade(s) de análise(s), ligação lógica entre os dados e as proposições; 4) critérios para interpretar os resultados (Idem).

$\mathrm{O}$ protocolo de pesquisa contém o instrumento de coleta e as normas gerais norteadoras de sua utilização. Na concepção de Yin (Idem), o protocolo proporciona maior confiabilidade à pesquisa e se faz desejável sob todas as circunstâncias e é essencial, quando se tratar de um projeto de caso múltiplo. Oferece os alicerces para a fase de coleta de dados, visando minimizar erros e vieses inerentes às pesquisas qualitativas.

Ainda segundo Yin (Idem), o protocolo do estudo de caso é mais que 
um instrumento; contém o procedimento e regras gerais que devem ser seguidas no uso do instrumento, abrangendo preferencialmente, as seguintes partes:

- visão geral do estudo de caso;

- procedimentos de campo;

- informações gerais e lembretes sobre procedimentos;

- questões do estudo de caso.

A partir de sugestões de autores citados, os procedimentos para coleta de dados compreenderam a definição das fontes e técnicas de coleta de dados; critérios para seleção dos casos; identificação dos casos; elaboração do roteiro de entrevista; realização de entrevistas e procedimentos para análise dos resultados.

A indústria brasileira de calçados tem sido objeto de vários estudos de pesquisadores brasileiros e internacionais. Na verdade, muitos desses estudos focalizam não a indústria calçadista em si, mas os sistemas locais de produção que são claramente identificados nesse setor. O foco dessa pesquisa foi centrado na análise das peças publicitárias sob os aspectos teóricos de Comunicação.

O contato com as empresas do setor calçadista foi realizado da seguinte maneira: primeiramente foi enviada pela pesquisadora uma carta, por e-mail solicitando a participação da empresa na pesquisa; em seguida, foram realizados contatos telefônicos para o agendamento da entrevista com o gerente de marketing; em seguida, as empresas disponibilizaram o material em arquivo eletrônico para análise (anúncios de revista e outdoors e catálogos).

Foram contatadas três empresas do setor calçadista que foram pesquisadas através de levantamento de dados secundários e de entrevistas com os dirigentes das empresas como Presidente e Gerente de Marketing. A opção por estudar empresas localizadas em Franca - Estado de São Paulo justifica-se por ser esse Estado, responsável por mais da metade do PIB nacional e considerado o mais rico e com o maior potencial de consumo do país (CENSO, 2000).

Foram estudadas as seguintes organizações: Carmen Steffens (calçados femininos e acessórios pessoais); Calçados Democrata e Calçados Sândalo (calçados masculinos). 
Justifica-se a escolha dessas empresas pelo deslocamento da produção das mesmas, em busca de vantagens competitivas relacionadas com os baixos custos do trabalho, maior diferenciação, a partir de investimentos em desenvolvimento de produto, incorporando aos seus produtos atributos diferenciados, valorizando a qualidade, o design e a sofisticação. Os instrumentos utilizados foram: maior racionalização dos processos de produção, a utilização de equipamentos mais modernos, a adoção de novas formas de organização produtiva; intensificaram também os seus esforços nas áreas comercial e tecnológica. Na esfera comercial, as estratégias focaram o fortalecimento de suas marcas, por meio de investimentos em propaganda, e à consolidação de canais de comercialização e distribuição dos produtos. A posse de marcas consolidadas, a existência de canais de comercialização e o lançamento de novos produtos permitem que a empresa pratique níveis de preços bem mais elevados no mercado interno do que quando elas estão vinculadas a esquemas globais de comercialização. A orientação dessas empresas inclui estratégias mais agressivas de valorização da marca através da associação das mesmas a nomes famosos e ao do mundo da moda (HIRATUKA; GARCIA, 2001, p. 49-64).

\begin{abstract}
A cada ano, os gigantes do mercado de difusão deixam de investir na segurança dos chamados produtos-estrela, ou seja, a indústria cada vez mais investe em produtos com elementos de moda, em detrimento dos tradicionais. Isto não quer dizer que os últimos irão deixar de ser produzidos, apenas aponta a mudança de tendência pela qual o setor como um todo está passando. Até o fim de 1998, a fabricação de sapatos dava-se em duas pontas: os direcionados para um público de bom poder aquisitivo e os produtos utilitários; hoje, mesmo entre as linhas de menor valor, são óbvios os elementos de moda (INDÚSTRIA DE CALÇADOS, 2002).
\end{abstract}

O segmento em que essa tendência pode ser verificada foi o feminino, especificamente as adolescentes. Após o boom na venda de tênis em 1999, houve um forte crescimento nas vendas de modelos mais sofisticados, com design moderno e inovador, encontrados em marcas com conceito de boutique, como no caso da Carmen Steffens.

A Indústria Democrata Calçados, de Franca (SP), registra um crescimento de 100\% nos últimos quatro anos. "A indústria, fundada há 18 anos, até bem pouco tempo não ultrapassava a casa dos três dígitos em 
produção". Hoje fabrica oito mil e quinhentos pares por dia, 15\% para o mercado externo. A Empresa Sândalo, maior fábrica de sapatos masculinos do Brasil aponta um crescimento de 10\% no faturamento depois de ampliar de 120 para 250 os modelos de calçados oferecidos no mercado às tendências de moda (Idem).

$\mathrm{Na}$ verdade, pode-se observar que as estratégias das empresas impuseram modificações importantes no mercado consumidor brasileiro. Mesmo as linhas de calçados sociais dos grandes fabricantes, dirigidas a um público conservador, "renderam-se às exigências dos executivos e incluíram nas suas linhas, como já faziam os concorrentes de pequeno porte, formas e cores mais arrojadas." Segundo estilistas e outros responsáveis pelo desenvolvimento de produto, o design do calçado masculino em geral sofreu recentemente grandes alterações. As linhas de produtos tradicionais, antes as únicas; hoje convivem com modelos arrojados que embutem um custo maior, composto por pesquisas de tendências da moda e de novos materiais, mas que por outro lado têm permanência infinitamente menor no mercado, justamente por tratar-se de moda. Diversas empresas têm elevado significativamente seus investimentos nas atividades de desenvolvimento de produtos e design. Para o lançamento dessas novas linhas, as empresas intensificaram os esforços em pesquisa das tendências internacionais, principalmente da indústria italiana, por meio de viagens à Europa até quatro ou mais vezes por ano a fim de visitar feiras de calçados, lojas das marcas mais importantes ou simplesmente saber o que o consumidor europeu está usando nas ruas. A partir daí, as empresas procuram adaptar essas tendências aos modelos mais difundidos entre 0 público brasileiro. O gasto com novos materiais também tem contribuído para a elevação do preço final dos calçados em geral, e dos modelos de vanguarda em particular (GORINI; CORREA, 2000).

\subsubsection{Carmen Steffens}

Fundada em 1991, na cidade de Franca/SP, por Mário Spaniol, empresário tradicional do setor coureiro, a Indústria de Calçados Carmen Steffens, marca sua presença no mercado de calçados, carteiras e acessórios 
femininos. Possui um estilo único e características que valorizam os seus produtos. Conhecida por seus produtos exclusivos, onde utiliza bordados a mão, cristais austríacos e materiais naturais brasileiros. Dirigida ao mercado feminino, classe social A e B, faixa etária de 15 a 30 anos - linha Urban; de 25 a 50 anos - linha tradicional Carmen Steffens, de estilo de vida arrojado e dinâmico, com perfil de mulheres elegantes, inteligentes e personalidades marcantes. A marca apresenta o conceito de calçado diferenciado com atributos de design moderno, estilo e qualidade. A grife apresenta além da qualidade e originalidade, a estrutura de produção, fábrica própria, curtume próprio e logística bem definida, que garantem abastecimento ágil a preços competitivos para o público-alvo, a alta classe média. Segundo Spaniol, diretor da empresa, o plano é abrir 300 franquias no exterior até o ano de 2020. Hoje a empresa conta com lojas na Arábia Saudita, Estados Unidos, México, Paraguai e Portugal, além de 90 franquias no Brasil (ENCARANDO A CONCORRÊNCIA, 2006).

\subsubsection{Democrata Calçados}

A Democrata, uma das líderes em calçados masculinos no Brasil, foi fundada em Franca (SP), em 1983, por Urias Francisco Cintra. Surgiu como uma "fabriqueta" de garagem com três funcionários e uma produção de trinta pares por dia. Hoje conta com três unidades de produção - duas em Franca (SP) e uma em Camocim (CE) - e 1.830 funcionários diretos, com uma produção diária de cerca de 8.500 pares de sapatos. Além de atuar fortemente no mercado nacional, a Democrata exporta para 58 países, incluindo Europa, América Latina, além dos Estados Unidos e México. Atualmente, 47\% da produção anual são destinadas ao mercado internacional.

\subsubsection{Calçados Sândalo}

A indústria de calçados Sândalo foi fundada em 1965. Desde então produz calçados masculinos primando pela qualidade e design diferenciado sem deixar de lado o conforto.

Direciona $70 \%$ da produção para o mercado interno e $30 \%$ para o externo. Ocupa uma área física de $10.000 \mathrm{~m} 2$. 
Segundo as mudanças de comportamento do seu público alvo, a Sândalo vem atualizando seu estilo e foca seus produtos em: casuais para o dia-a-dia e sociais modernos para ocasiões especiais. 


\subsection{PESQUISA DOCUMENTAL}

\subsubsection{Análise e Interpretação}

\subsubsection{Carmen Steffens}

Calçados e acessórios podem ser considerados objetos com significados produzidos e distribuídos no mundo todo seguindo as tendências da moda. Seus modelos, materiais e formas de utilização transmitem mensagens para todo o contexto sócio econômico em que os usuários estão inseridos. São produzidos em série pelas marcas que lançam a moda, mas também são copiados e adequados aos públicos diversos com distinções quanto ao grau de realismo, abstração, ou exagero, com o qual representam elementos de práticas sociais. Constituem 'objetos' para serem lidos como textos. O seu significado é dividido entre: os fabricantes que o inserem através do posicionamento da marca; pelos designers da indústria; pela comunicação; e pelo usuário do produto. O seu significado pode ser implícito ou explícito, são um repositório das ideologias e 'sistemas de valores' sociais.

Os sapatos como os da grife Carmen Steffens das linhas Carmen Steffens ou Urban, representam atores sociais através do modo como são projetados em temos de design, materiais, combinação de cores, e estão sempre condicionados pelas ideologias sócio-culturais contextualizadas. Segundo Hall (1997, p. 61), representação é:

o processo através do qual membros de uma cultura usam sistemas de significação para produzir significado... Objetos, pessoas, eventos no mundo não têm em si mesmos qualquer significado fixo, final ou verdadeiro. Somos nós, em sociedade, que atribuímos significado às coisas e ao mundo que nos rodeia. Os significados, conseqüentemente, irão sempre mudar, de uma cultura ou período para outro.

Conforme o autor calçado e acessório enquadra-se, portanto, em papéis, no sentido de que eles representam a sociedade nas suas relações de poder inscritas em papéis sociais, suas tecnologias, suas identidades e práticas sociais. 
A linha Urban apresenta atributos linkados à mistura dos gêneros feminino e masculino com os quais as garotas mais jovens se identificam, como: ser forte física e psicologicamente; a ousadia e a busca pelo novo; a identidade aventureira, o despojamento, o descompromisso, a casualidade. Suas características físicas conotam exagero à beira da distorção. A construção do vestuário afirma a sua sexualidade (BRAGA, 1972, p. 9-10).

Já a linha tradicional Carmen Steffens, representa o perfil da mulher inovadora, moderna, sensual, diferenciada, experiente, que utilizam através da construção do seu visual a afirmação e postura da sua personalidade. Apesar do estilo diferenciado, a pose e aparência da usuária, são representantes da busca pelo encanto, pela beleza e sensualidade, pelo prestígio e status, e do reconhecimento socialmente desejável.

Podemos verificar que a construção de sentido dos textos verbais e visuais dos anúncios, banners, catálogos e outdoor apresentados no estudo, estão diretamente relacionados com a identificação da marca neles contidas. $O$ sentido dos textos são assegurados pelas reações emocionais e intelectivas desencadeadas pelos estímulos visuais, como: perspectiva, disposição dos produtos e objetos no espaço físico, plano, cores, moldura limite etc (KRESS; VAN LEEUWEN, 1996). Os efeitos de sentido da imagem fotográfica podem ser aprendidos de duas maneiras: pela ótica do anunciante - fabricante do produto - e outra pela consumidora. A análise se atém ao posicionamento do anunciante através das peças publicitárias que constituem o corpus do estudo. 
Figura 12: Anúncio de Revista Marie Claire, julho 2005 e Banner

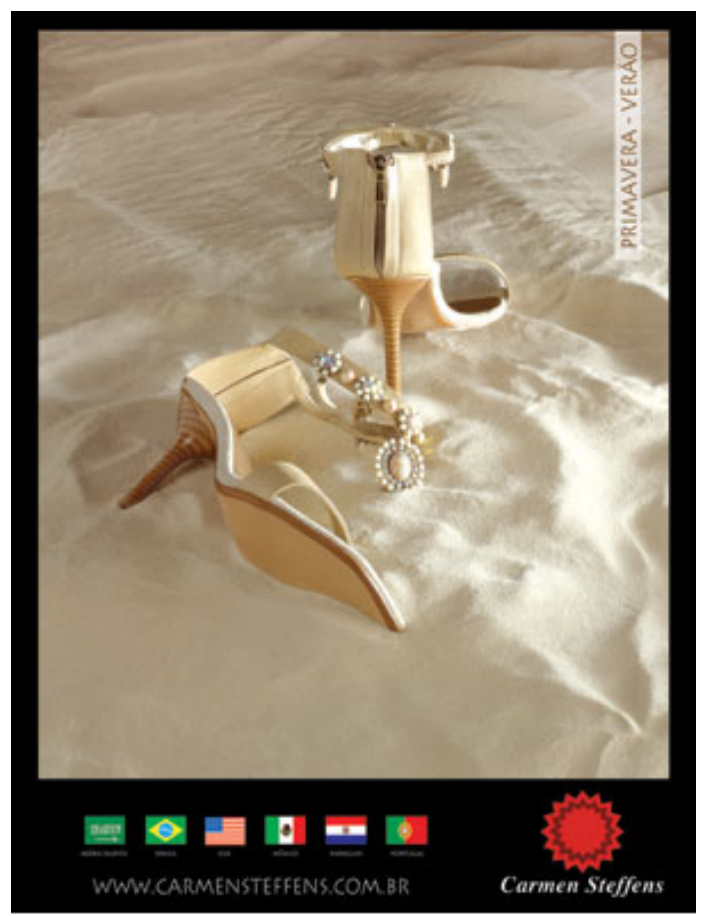

\section{ANÚNCIO DE REVISTA E BANNER}

Fonte: Arquivo eletrônico do Depto. Marketing da Carmen Steffens.

No texto visual, o discurso do enunciador (anunciante) apresenta a perspectiva da imagem enquadrando um único sujeito, o produto sandália, da coleção primavera verão do ano 2005, apresentando detalhes particulares, contextualizado em uma atmosfera de praia, sobreposta diretamente na areia, transportando a receptora ao cenário. Holisticamente, a palavra praia e a sua visualização "areia branca", indicam progresso, sucesso e bem estar (BEMZEM, 2006). A monocromia (FARINA, 1987) contribui de forma significativa para a efetivação da atmosfera agradável dessa estação do ano, provocando diferentes sentimentos e emoções do espectador. O texto verbal apresenta os países onde o produto é comercializado, finalizando com a assinatura da marca - logotipo da Carmen Steffens. 
Figura 13: Indoor

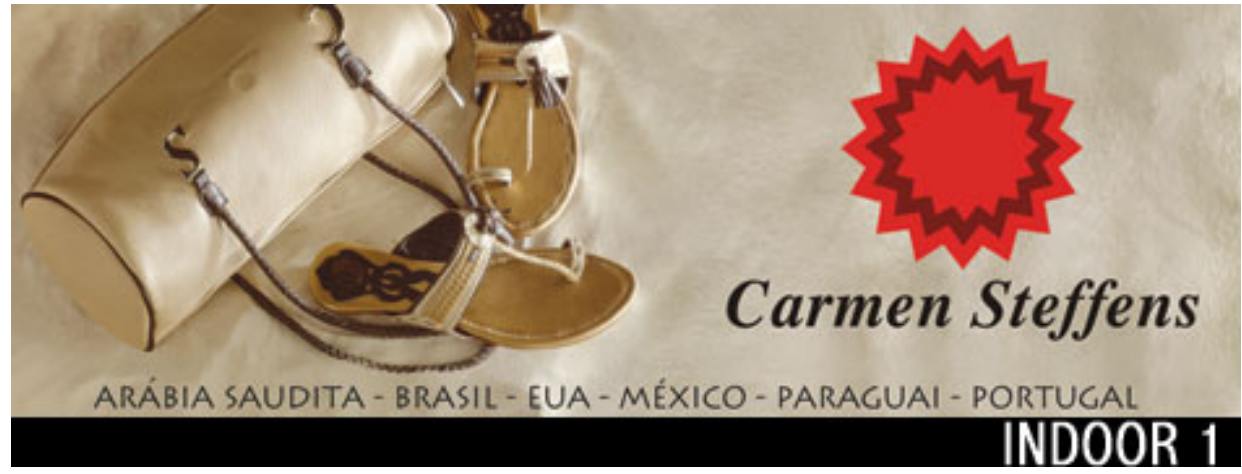

Fonte: Arquivo eletrônico do Depto. Marketing da Carmen Steffens.

Figura 14: Outdoor

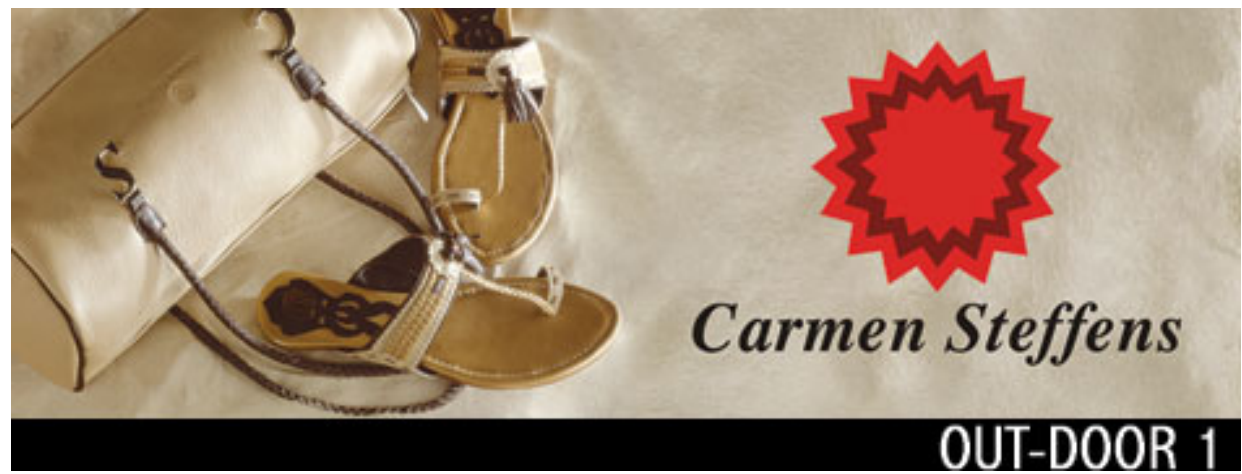

Fonte: Arquivo eletrônico do Depto. Marketing da Carmen Steffens.

O tipo de campanha de propaganda utilizado nas Figuras 13 e 14 são de produto (LUPETTI, 2000; CABRAL, 1991, p. 43-44) que tem o enfoque de um determinado produto da marca, seu objetivo é vender um produto específico, no caso sandália e bolsa, projetada para estimular a demanda na estação do ano, informando e ressaltando os benefícios apenas com a linguagem visual. $O$ anunciante busca chamar a atenção do receptor despertando o prazer estético, a fim de obter a memorização da mensagem e levar ao consumo. A associação por contigüidade, indica proximidade, vizinhança, adjacência (CARRASCOZA, 2003. p. 15). Por conseguinte, a referência à areia da praia, transporta a consumidora em potencial do produto ao local agradável, repleta de pessoas bonitas, felizes, de bem com a vida e que precisam usar acessórios bonitos e adequados como os produtos da Carmen Steffens. 
Figura 15: Placa Teen Urban, verão 2005.

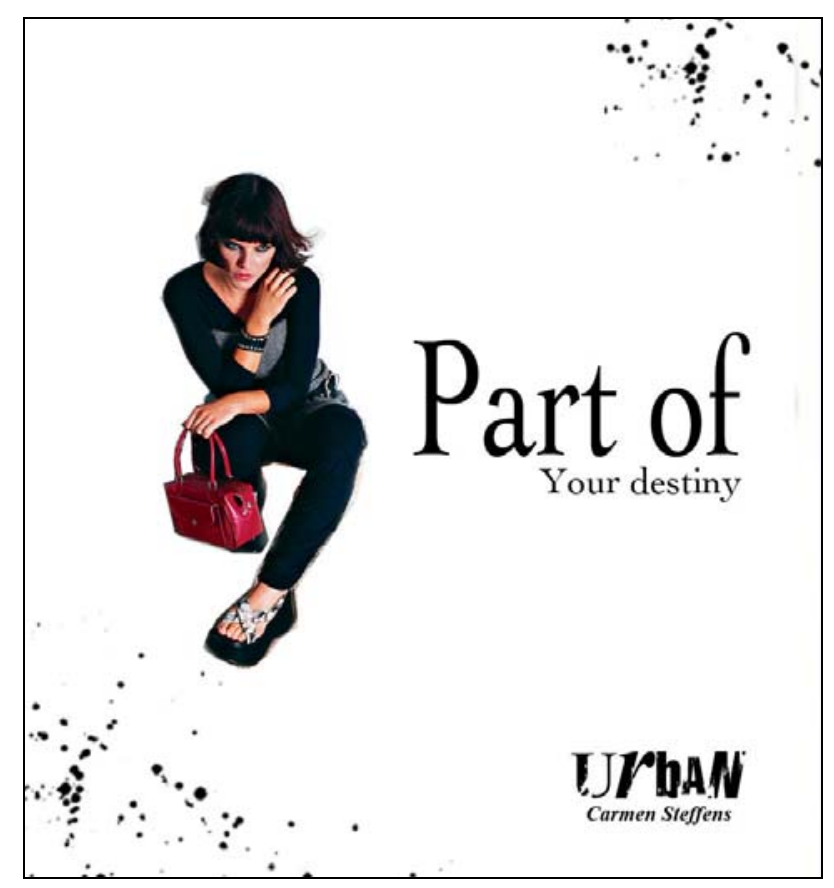

Fonte: Arquivo eletrônico do Depto. Marketing da Carmen Steffens.

Nesta peça publicitária o texto verbal mostra a utilização de empréstimos lingüísticos viciosos, com a influência de línguas estrangeiras, o inglês, a utilização de letras ou combinações de letras chamadas exóticas ou estranhas. O slogan "part of your destiny" posiciona os produtos da linha "Urban" como essencial, fundamental para a consumidora. A assinatura leva a marca da linha direcionada ao público tennager (13 a 19 anos) e a assinatura do fabricante "Carmen Steffens" sem a utilização do logotipo. O texto visual comunica o posicionamento do produto para o público com um estilo mais jovial, diferenciado e contemporâneo. Segue a linha fashion ou vanguarda do mercado da moda (LEECH, 1966). 
Figura 16: Linha Urban

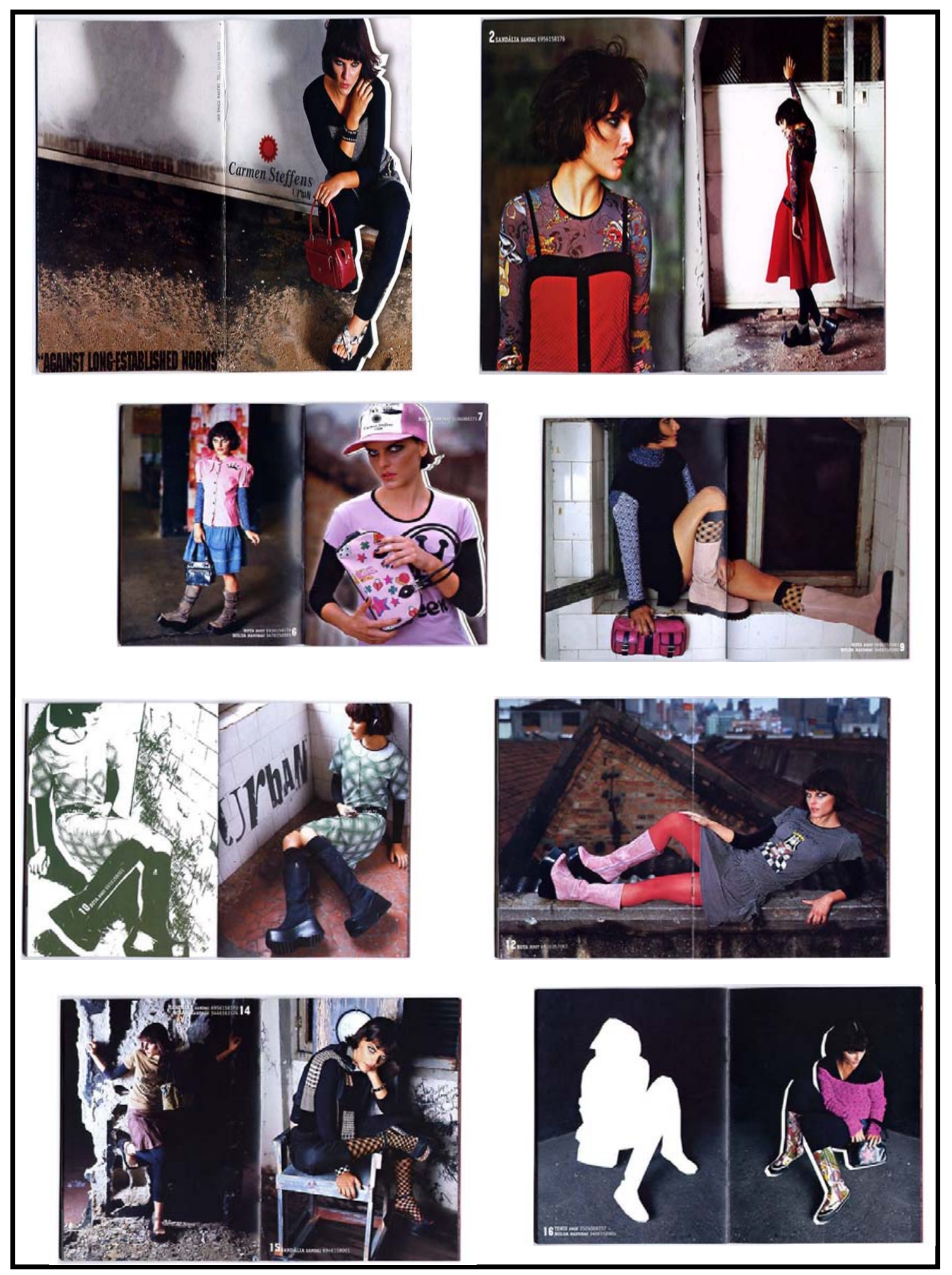

Fonte: Catálogo linha Urban primavera/verão 2005. 
Figura 17: Natal 2005

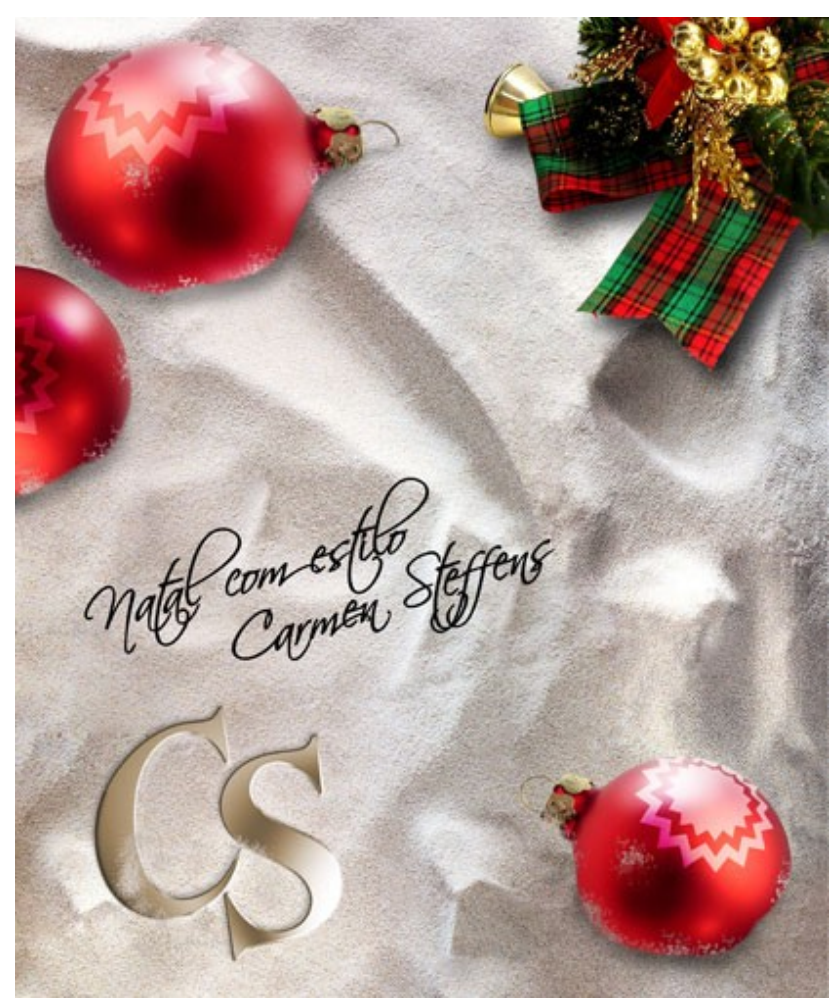

Fonte: Arquivo eletrônico do Depto. Marketing da Carmen Steffens.

A Figura 17 mostra a peça institucional da marca - Cartão de Natal. A linguagem verbal apresenta objetos com motivos natalinos: bolas de vidro; sino dourado; laço de fita; tridimensionais que podem ser lidos e interpretados como textos. Dá a idéia de continuidade em relação às peças anteriores pela textura de areia, utilizada em todos os outros anúncios da coleção da primavera/verão da grife. Semioticamente falando, como objetos materiais concretos produzidos em discurso, e sua estrutura comunicativa; Objetos para serem manipulados e usados, passam o sentido de que os presentes deverão ser estilosos como os produtos da marca (HODGE.; KRESS, 1988, p. 6). A linguagem verbal, constituída do slogan "Natal com estilo Carmen Steffens" seguido das iniciais da marca "CS", sem a inserção do logotipo entendido como quebra de um padrão da comunicação da marca. 
Figura 18: Outdoor, Inverno 2006

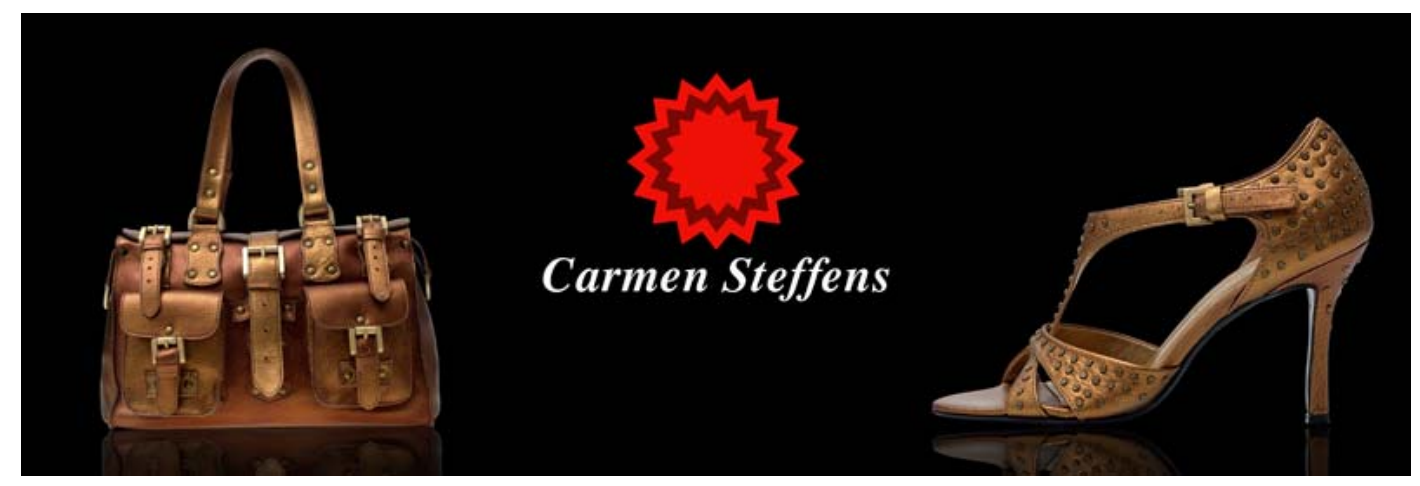

Fonte: Arquivo eletrônico do Depto. Marketing da Carmen Steffens.

A Figura 18 apresenta a peça de divulgação da coleção de Inverno, utilizada em mídia exterior - Outdoor. A linguagem visual apresenta um layout simétrico, tradicional, com exposição única e exclusiva dos produtos. A sobreposição dos produtos na cor ouro e cobre remete ao luxo, riqueza, status e prestígio, sobreposto sobre o fundo preto traduz sofitiscação. A cor preta tem conotação de nobreza, seriedade (FARINA, 1987). A forma e o estilo da enunciação indicam a existência real, a ideologia do cotidiano representa a totalidade da atividade mental centrada no dia-a-dia do ser. O posicionamento do anunciante apresenta o produto destacando seu estilo, design, sofisticação e personalidade. Esse significado é passado através dos elementos visuais: cores; elementos; disposição perspectiva; iluminação. De acordo com Bakthin (1992 b), a obra estabelece vínculos com a consciência dos indivíduos receptores, e é interpretada dentro do espírito desse conteúdo e assim, recebe uma nova luz. Ela é levada a estabelecer contatos ideológicos ininterruptos dentro do cotidiano vivido, isso a faz significante. A linguagem verbal apresenta a assinatura da marca com seu logotipo. 
Figura 19: Anúncio de revista, Outdoor e Indoor, Inverno 2006.
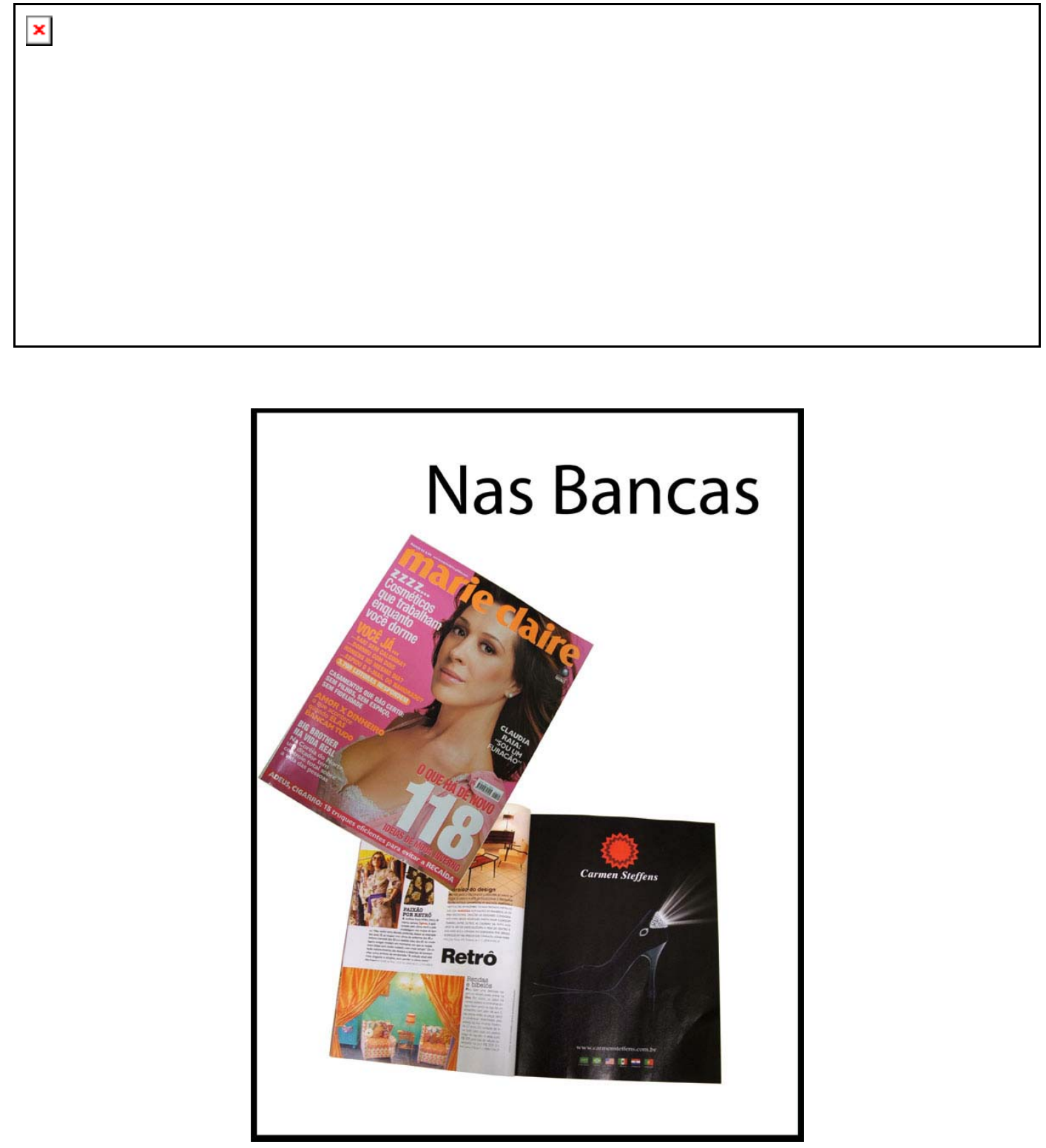

Fonte: Arquivo eletrônico do Depto. Marketing da Carmen Steffens.

A Figura 19 mostra a peça publicitária, com estilo simétrico, apresentando do lado esquerdo o slogan "vivendo com estilo" o produto ao centro, com efeito, de brilho remetendo-o ao brilho de diamantes, orientados para a assinatura à direita com o logotipo da marca. Utiliza o aspecto sintático da simplicidade estrutural, apresentando o slogan como título ou apelo principal, deixando elementos subtendidos apenas na análise do contexto (SANDMAN, 2001). 
Figura 20: Indoor, Inverno 2006

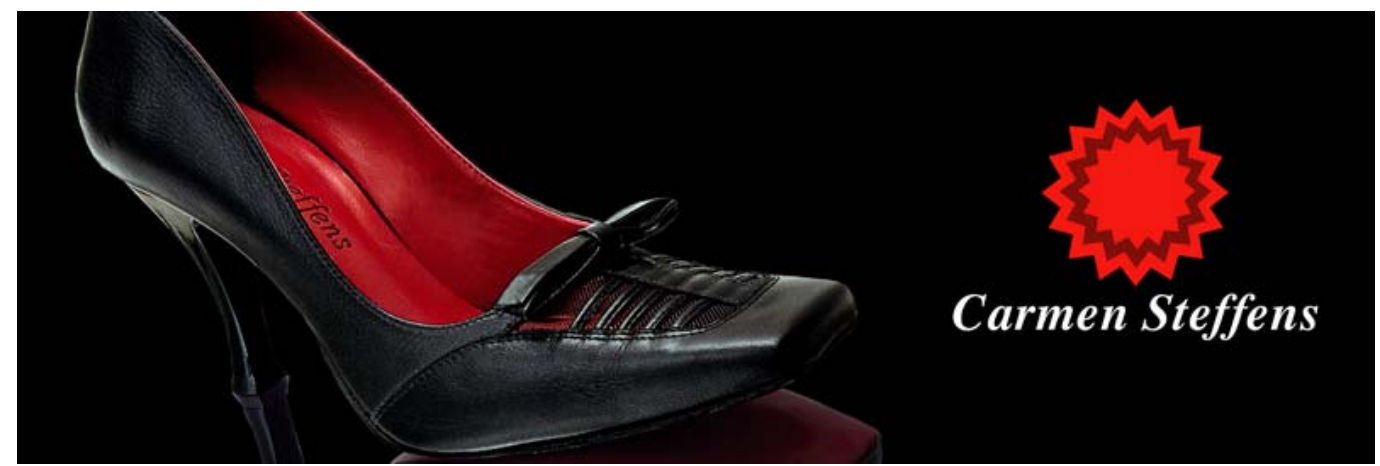

Fonte: Arquivo eletrônico do Depto. Marketing da Carmen Steffens.

Figura 21: Outdoor Inverno 2006

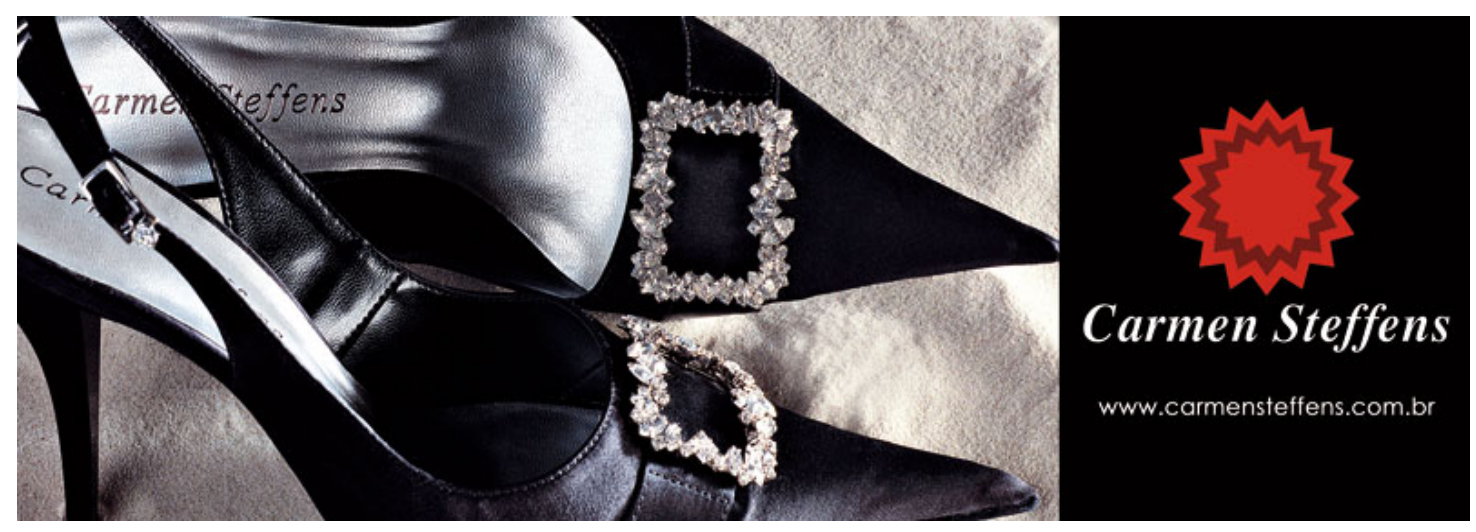

Fonte: Arquivo eletrônico do Depto. Marketing da Carmen Steffens.

As Figuras 20 e 21 apresentam peças de mídia exterior - outdoor - da Coleção Outono/Inverno. A linguagem visual, mostra em close a riqueza de detalhes dos produtos - sapatos - sobrepostos em fundo preto, no mesmo padrão utilizado nas outras peças publicitárias da coleção da estação. Na linguagem verbal, o logotipo da marca e somente na última peça também está presente o endereço eletrônico. 
Figura 22: Revista 'Quem' 14/4/2006

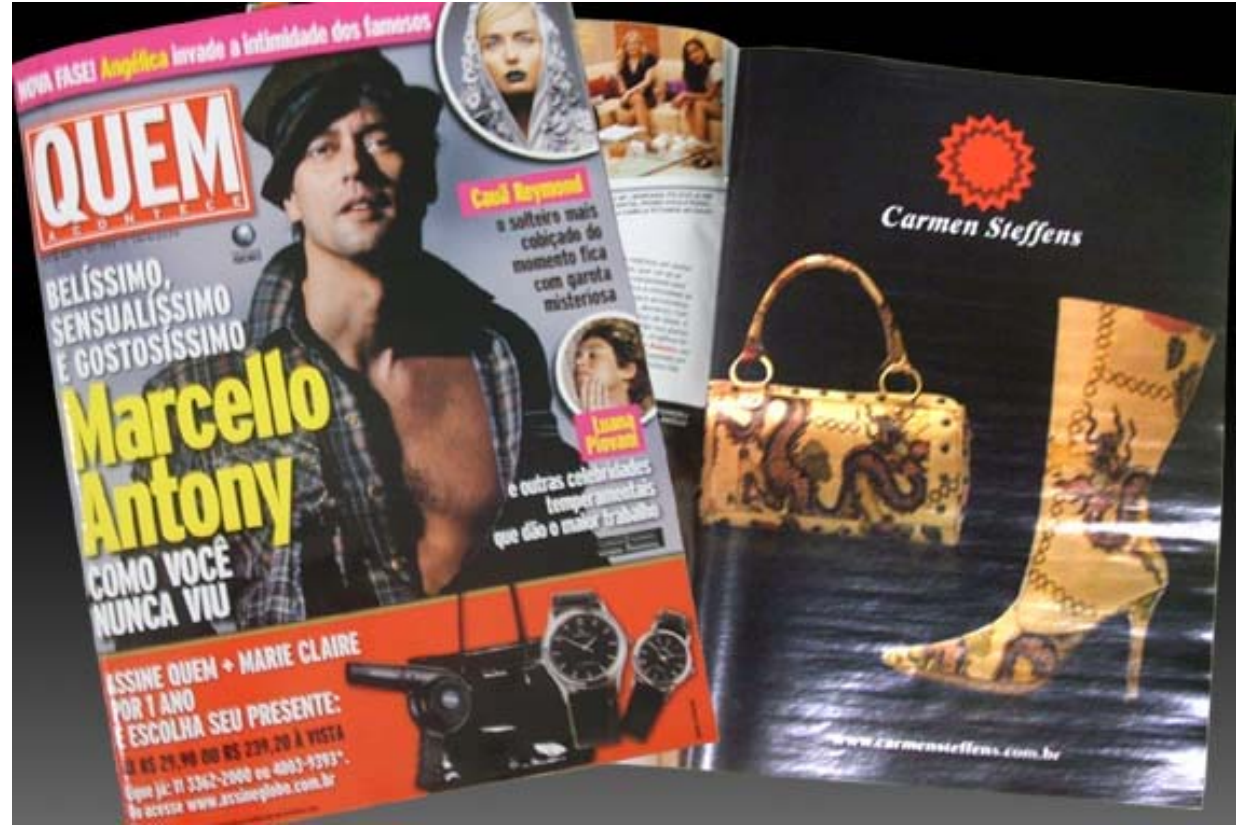

Fonte: Arquivo eletrônico do Depto. Marketing da Carmen Steffens.

Figura 23: Back light, inverno 2006.
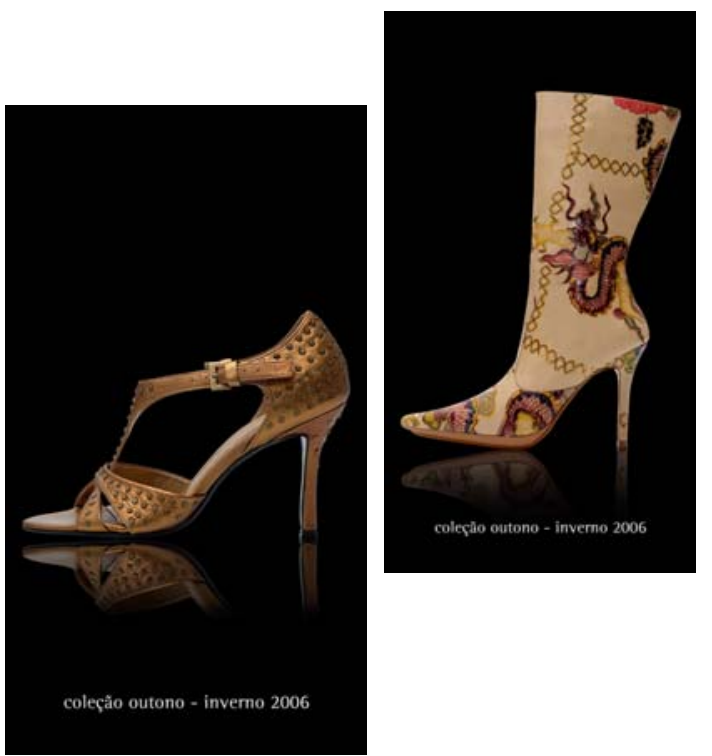

Fonte: Arquivo eletrônico do Depto. Marketing da Carmen Steffens.

As Figuras 22 e 23 mostram: o anúncio da revista Quem e back light, explorando o conceito da Coleção Outono/Inverno. A linguagem visual, as 
fotografias da composição de bota e bolsa, sobrepostos em fundo preto, segue o mesmo padrão utilizado nas outras peças publicitárias da coleção da estação. Na linguagem verbal, o logotipo da marca e endereço eletrônico.

Entende-se, assim, que calçados e acessórios são, simultaneamente, comunicações já produzidas e ferramentas com as quais se produzem significados. Podemos traçar analogias entre os mesmos como sistemas comunicativos e a linguagem como um sistema - ambos produzem significados ideológicos, interpessoais e textuais. Existe uma intenção com os objetos de acordo com estas três dimensões. Os calçados como um "sistema semiótico projeta as relações entre o produtor de um signo ou um signo complexo, e o receptor/reprodutor daquele signo. Também projetam uma relação social particular entre o produtor, o observador e o objeto representado, podem ser contextualizados e interpretados de muitas maneiras diferentes, através de contextos sociais, econômicos, culturais etc (BAUDRILLARD, 2000; BRAGA, 1977, p.69-73; BRAGA, 1972, p. 69-73). 
Figura 24: Linha Urban Outono / Inverno 2006.
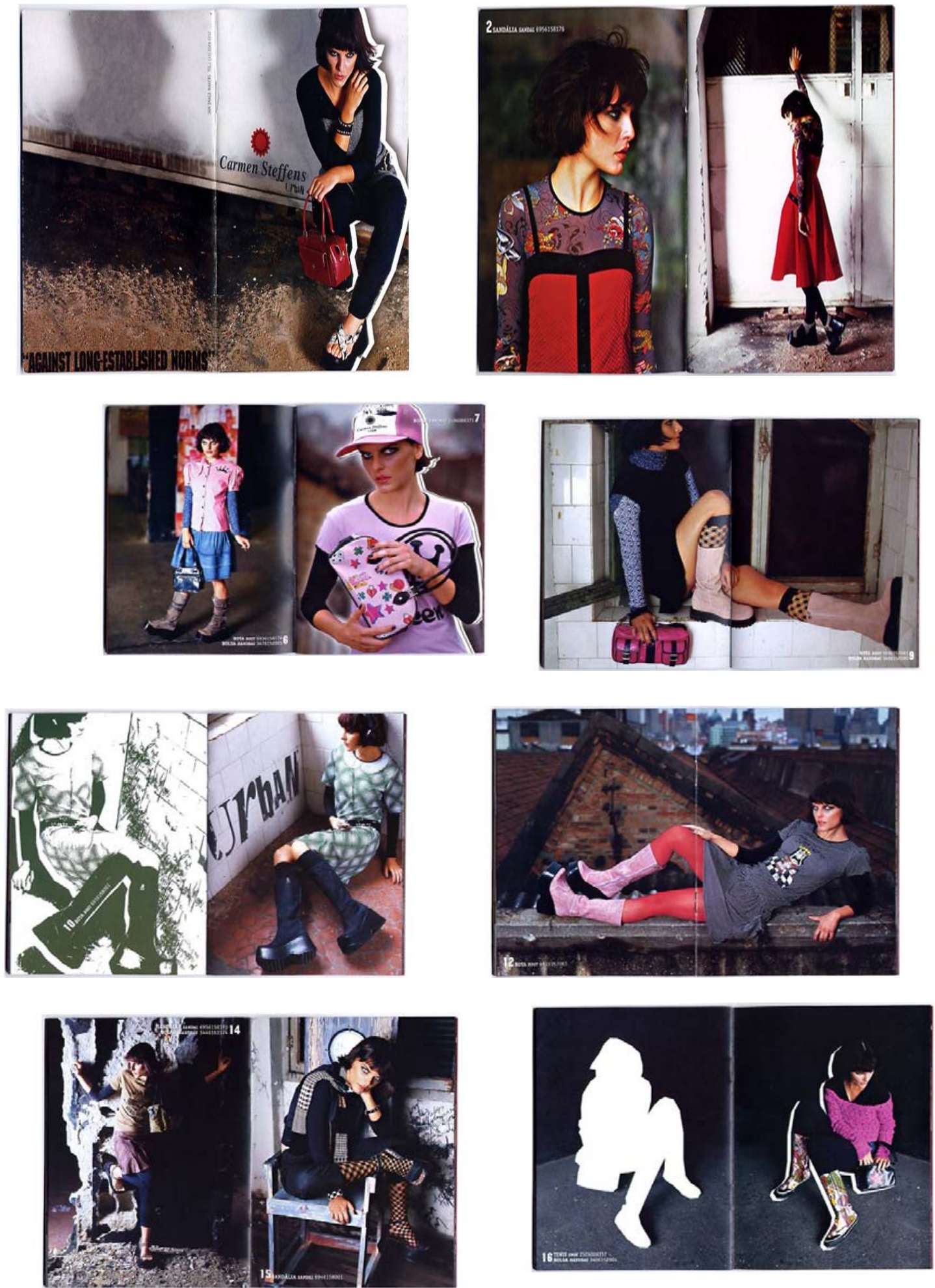

Fonte: Catálogo linha Urban Outono/Inverno 2006. 
Figura 25: Linha Urban Outono / Inverno 2006
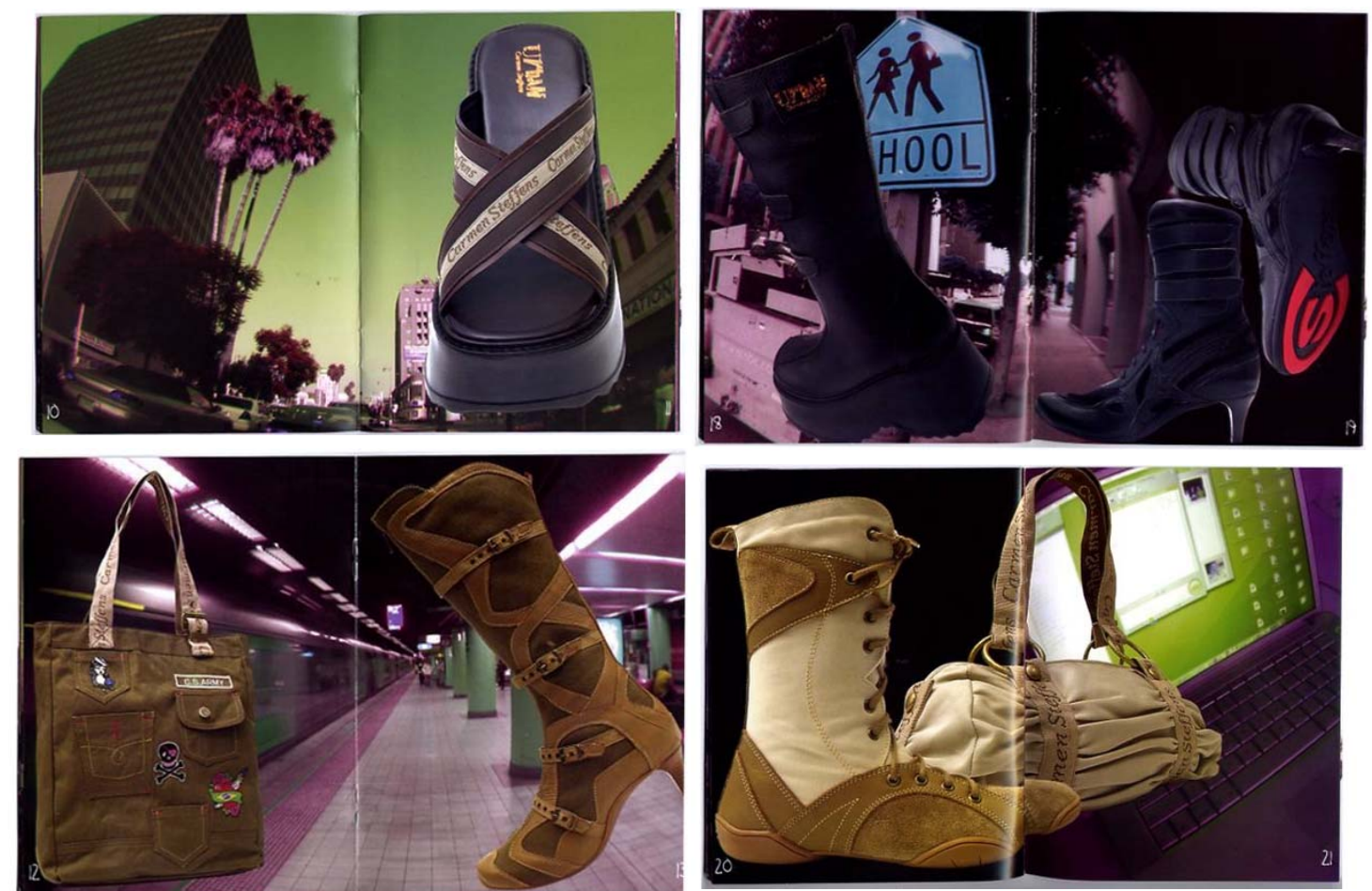

Fonte: Catálogo linha Urban Outono/Inverno 2006.

Uma das formas de apresentar a realidade na comunicação visual é através da cor, do foco e da profundidade (perspectiva), que podem ser idealizados em um grau maior ou menor. A cor desempenha um papel em todas as orientações de código. Existe a cor abstrata (o rosado uniforme para os rostos, ou o esverdeado, para a grama); a cor naturalística, ou ainda a cor sensorial - a cor se torna sensorial à medida que 'excede' o naturalismo. A cor também é fonte de prazer e produz (ou não) significados afetivos. As pessoas reconhecem o valor emotivo e sensual das cores. Através de tons diferentes, o princípio do prazer é encenado. Reagem positivamente às cores que as atraem. E as cores em geral estão carregadas de significação social. A cor pode ser um importante significante de gênero. Assim como na tradicional oposição entre as roupas de bebê azuis e cor de rosa, ou os marrons e cinzas 
que dominam as roupas dos homens e os tons mais claros que estão associados às roupas femininas (FARINA, 1987 e KRESS; VAN LEEUWEN, 1996).

Tons de rosa, arroxeado, vermelho, escarlate são cores raras na natureza, encontradas em flores ou pedras preciosas, ou em manchas coloridas de aves tropicais. O seu significado está relacionado a esta raridade. Quando essas tonalidades são empregadas, sempre carregam um significado semântico que significam 'algo especial'. Contexto e grau de escuro e intensidade irão enfatizar ainda mais esse significado especial, por exemplo, tendendo na direção do mistério, ou do perigo, ou da sexualidade. Ainda assim, é possível que essas cores atuem de forma intertextual como pano de fundo em qualquer interpretação mais restrita: no mundo dos calçados com design arrojado, a sexualidade sempre será misteriosa e perigosa, por exemplo, e o perigo também pode ser sexualmente excitante. E como os mesmos tons de rosa, arroxeado, vermelho, escarlate não apenas predominam nos catálogos de calçados, mas também nos cenários de programas de televisão e na decoração dos interiores dos espaços públicos e privados, a mesma atitude permeia o todo de uma sociedade pós-moderna, que é simultaneamente cheia de riscos e saturada de sexualidade, representada nos catálogos da linha Urban, destacadas nas localidades como ruas, metrô e objetos como computadores representando a inserção tecnológica.

Considera-se presente em todas as Figuras apresentadas 0 conceito de Bakthin (2002, p. 123) a respeito do sentido da enunciação completa o seu tema. As peças em estudo apresentam uma significação unitária, que pertence a cada enunciação como um todo. O tema se reporta ao instante histórico ao qual pertence: "Primavera/verão 2005"; "Natal 2005"; "Inverno 2006". O tema da enunciação das peças publicitárias apresentadas foi definido pelos elementos não verbais: produtos; efeitos visuais como sombra e brilho; cores; etc.

\subsubsection{Democrata Calçados}

Desde a sua fundação a Indústria de Calçados Democrata mantém a postura de desenvolver produtos com conceitos diferenciados 
(moda ou estilo de vida). O resultado está no reconhecimento da marca pelo consumidor. Com esse foco, a Democrata pôde desenvolver tecnologias de conforto aliadas ao design de moda e detalhes artesanais. Esta postura está presente nos 8.500 pares produzidos diariamente, desde a concepção do projeto até o acabamento; o calçado Democrata traduz a qualidade como o diferencial da marca (COBRA; RIBEIRO, 2000).

A empresa tem o seu histórico marcado por decisões inovadoras e iniciativas pioneiras, na gestão, no desenvolvimento de produtos e, principalmente na comunicação, junto aos distribuidores e consumidor final. No final de 2000, a empresa contratou o ator Reynaldo Gianecchini como garoto propaganda. Tendo acompanhado a marca por três anos, o ator trouxe o espírito fashion e moderno, que a marca necessitava naquele momento. Com os objetivos cumpridos, a marca partiu para um novo ciclo de comunicação, dando foco no produto, seguindo essa linha por mais dois anos. Em 2006, utiliza na sua comunicação a figura de uma mulher. A campanha é inspirada nos anseios do homem para proporcionar a elegância em todos os momentos da sua vida, sob o enfoque do olhar sedutor feminino.

A Indústria de Calçados Democrata utiliza como estratégia de comunicação: mídia impressa (revistas - em circulação nacional e outdoor nas principais cidades do país); mídia eletrônica (vinhetas em TV a cabo ESPN, Sport TV e GNT e merchandising TV aberta). Para o objeto dessa pesquisa, serão analisadas as peças veiculadas em mídia impressa: revista e outdoor. 
Figura 26: Anúncio de Revista - Dia dos Namorados No 1 - 2003

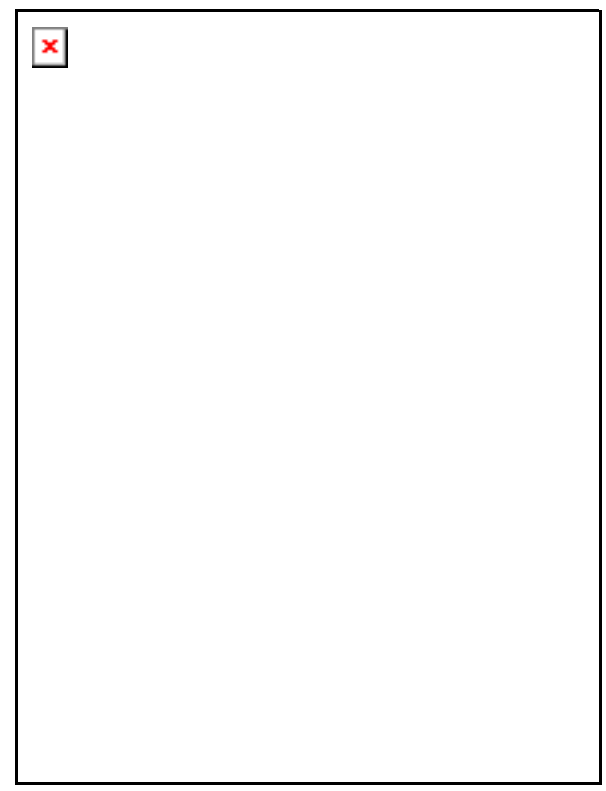

Fonte: Arquivos do Depto. de Marketing da Democrata

Figura 27: Anúncio de Revista - Dia dos Namorados № 2 - 2003

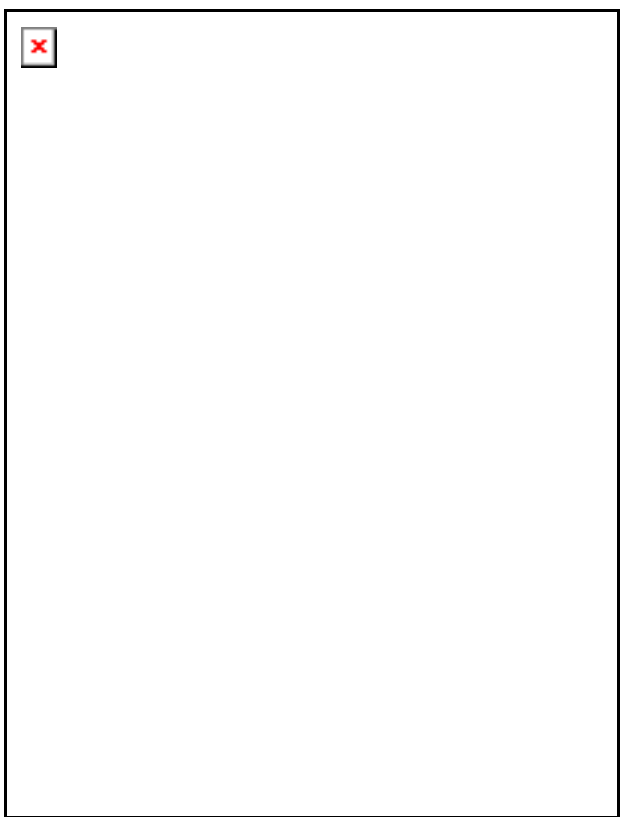

Fonte: Arquivos do Depto. de Marketing da Democrata 
O tipo de propaganda utilizado nos anúncios das figuras 26 e 27 são do tipo testemunhal, com a imagem do garoto propaganda Reynaldo Gianecchini, que dispensa apresentação. Ator de sucesso reconhecido pela sua beleza, popularidade e simpatia; ao lado da sua namorada, Marília Gabriela, também reconhecida pela sua atuação como atriz e jornalista de renome. O casal atesta a marca, emprestando a mesma, a imagem positiva que possuem. A linguagem visual do anúncio apresenta a fotografia em preto e branco do casal encenando um abraço, com a expressão de felicidade e a foto do produto em cores (esportivo na Figura 26 e social na Figura 27). A linguagem verbal apresenta o título Dia dos namorados e a assinatura da marca Democrata com seu logotipo e a linha do produto Flex Gel.

Figura 28: Anúncios de Revista - Dia dos Pais - 2003

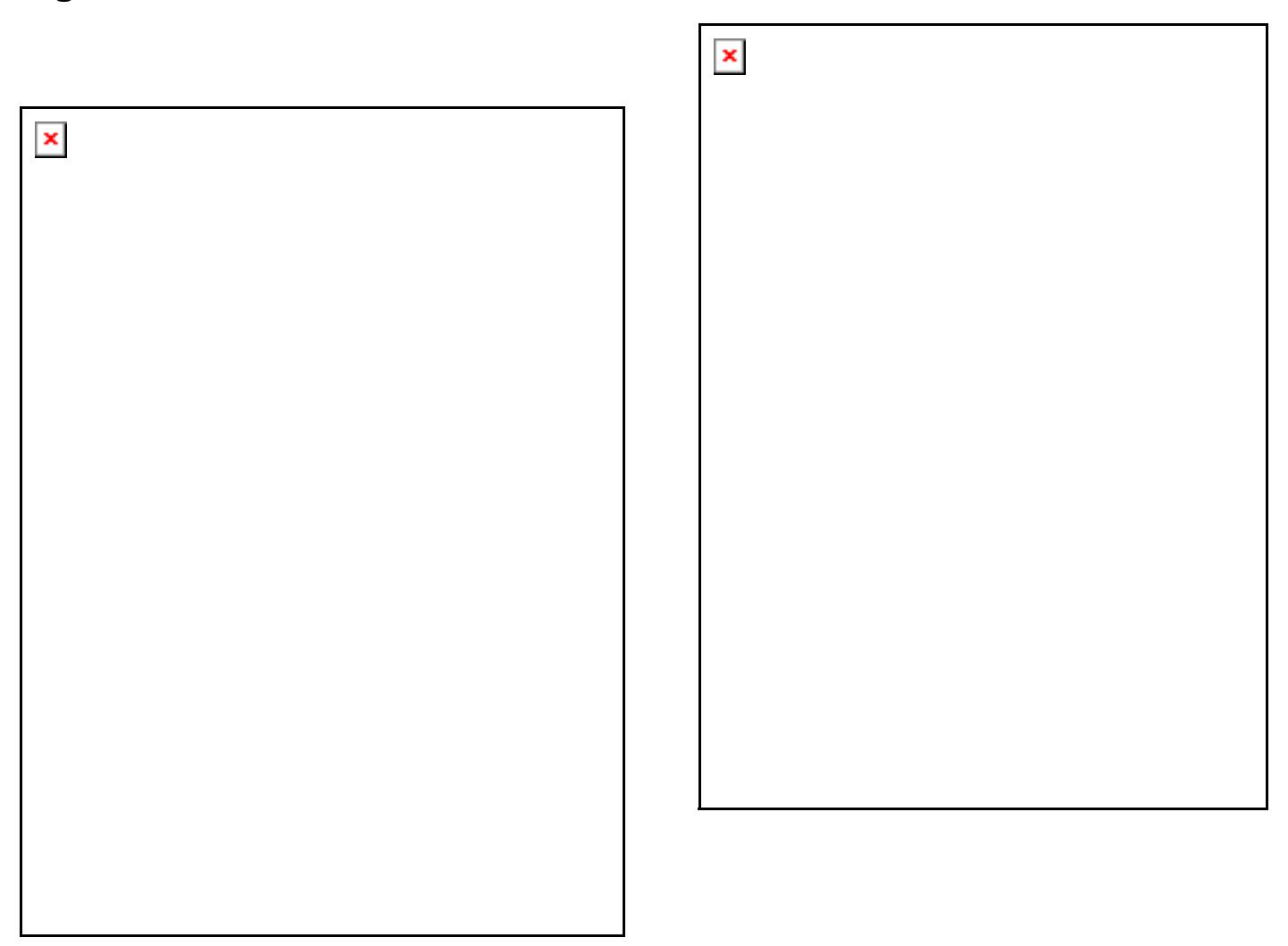

Fonte: Arquivos do Depto. de Marketing da Democrata 
Seguindo a mesma linha comunicacional, os anúncios testemunhais apresentados na Figura 28, com Reynaldo Gianecchini, e o seu pai atestam a marca. A linguagem visual do anúncio apresenta a fotografia em preto e branco de pai e filho, o ambiente é de um parque com a expressão de harmonia e felicidade. A foto do produto em cores (apresentando as linhas Flex Gel e Air). A linguagem verbal apresenta o título Dia dos pais e a assinatura da marca Democrata com seu logotipo e a linha do produto.

Figura 29: Anúncios de Revista - Coleção Outono Inverno - 2003

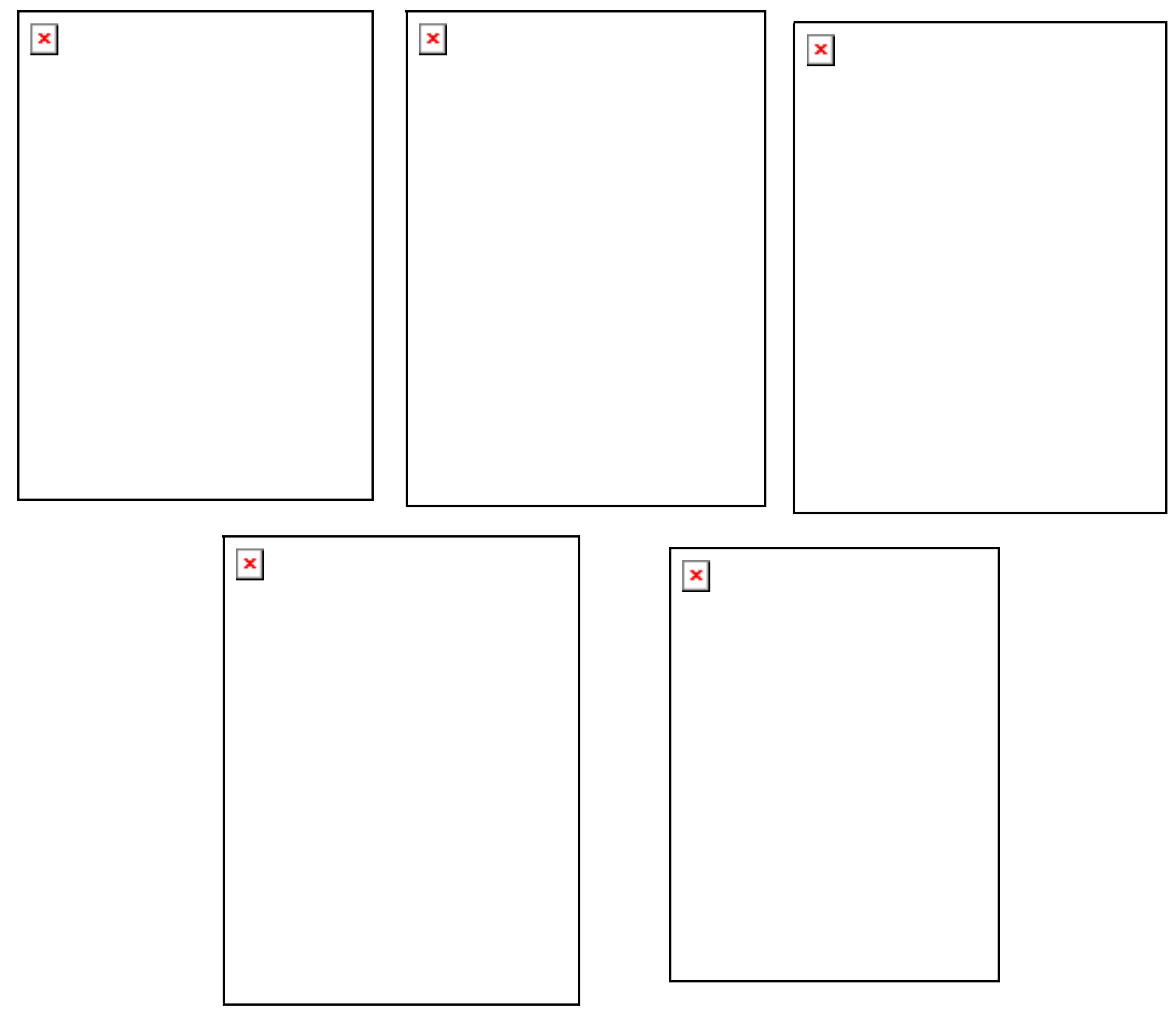

Fonte: Arquivos do Depto. de Marketing da Democrata

A campanha Outono Inverno utiliza basicamente a estratégia de comunicação de testemunho. 
De acordo com Lupetti (2000) a estratégia de testemunho é bastante aplicada para dar credibilidade ao produto. O uso de celebridades atores e atrizes consagradas - pode trazer um bom retorno à campanha publicitária.

O primeiro anúncio apresenta com título a marca "Democrata" (logotipo) e o subtítulo "couro com lycra". O texto "o ajuste perfeito; liberdade de movimentos; flexibilidade ao caminhar" compõe a justificativa do diferencial do produto: jovem, bonito e confortável, e a imagem desejada é usar o mesmo sapato que o Gianecchini usa. Ficar tão bonito quanto o Gianechini. O segundo e o terceiro anúncio destacam o garoto propaganda e assina a marca Democrata e a linha do produto Air (logotipo) com o slogan "O conceito. $O$ conforto". Subentende-se por "o conceito" o design, a qualidade, o bom gosto; e por "O conforto" o sapato bonito e gostoso no pé. Apresenta o selo do Certificado de conforto da ABNT e o texto "o primeiro a receber o certificado de conforto da ABNT. O único com o sistema de absorção S.A.A.". O quarto anúncio apresenta a linguagem visual do Gianecchini usando o produto e a assinatura e o quinto dá ênfase ao benefício oferecido pelo solado do calçado, seguido da assinatura da marca Democrata e da linha de produto Flex Gel. 
Figura 30: Anúncios de Revista - Coleção Primavera Verão - 2003
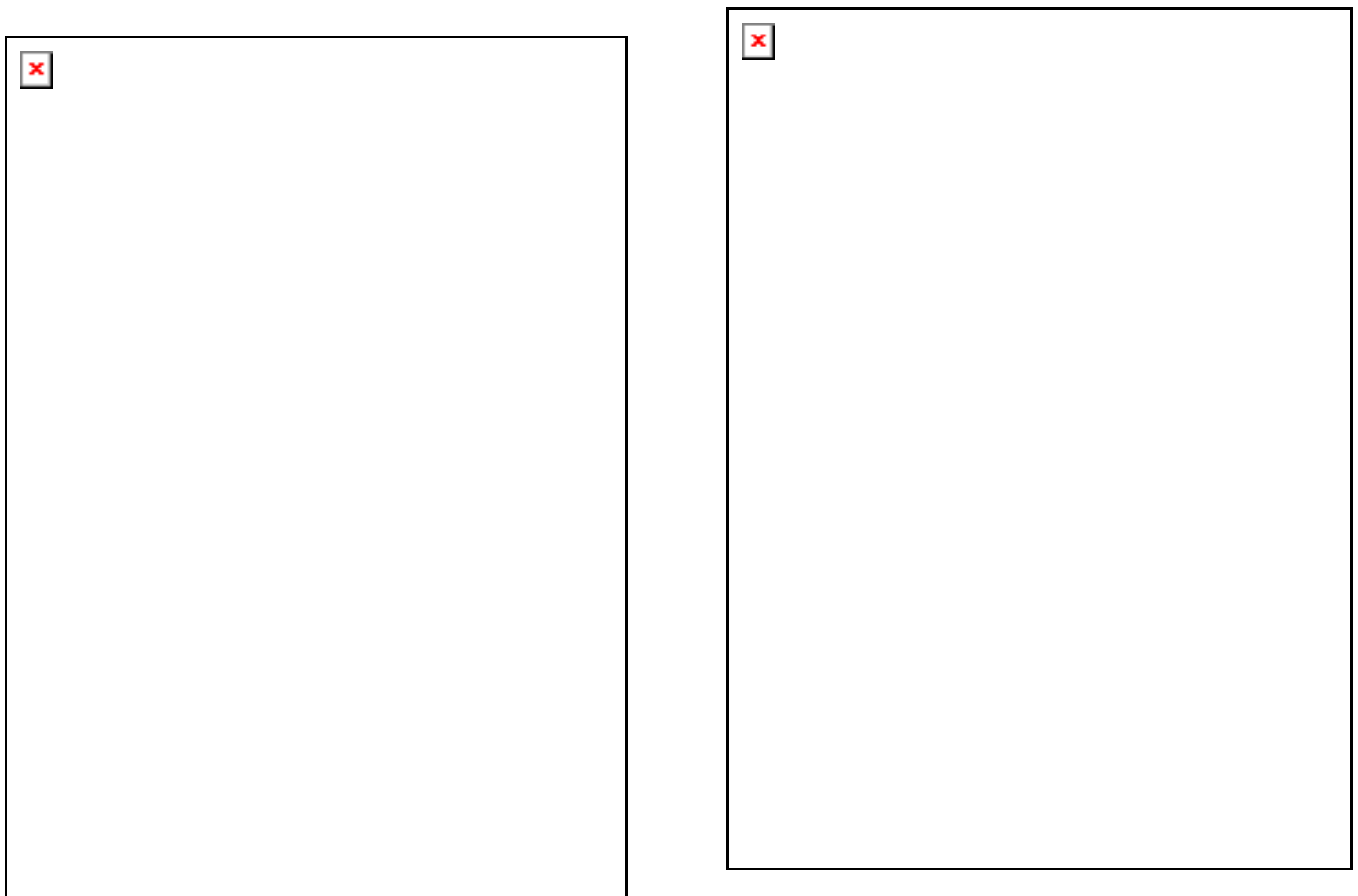

Fonte: Arquivos do Depto. de Marketing da Democrata

A campanha Primavera Verão dá continuidade à estratégia de comunicação (LUPETTI, 2000) de testemunho (Figuras 30 e 31). O primeiro anúncio destaca Gianecchini usando os produtos da marca Democrata em diversas situações. O primeiro anúncio apresenta vários produtos esportivos e o segundo anúncio, com apenas as pernas e mãos do modelo, mostra o Produto da linha Taller que destaca no seu texto o benefício do produto 'deixa o usuário até 6,2 cm mais alto'. O slogan 'Aumente seu estilo' apresenta o seu significado na relação de causa e efeito, onde a causa - problema é melhorar a performance do fator estilo de uma pessoa que a altura não corresponde ao padrão de beleza estabelecido pela sociedade, o efeito - solução, é a utilização do produto da linha Taller, que soluciona o problema e aumenta a altura em até $6,2 \mathrm{~cm}$. 
Figura 31: Anúncios de Revista - Coleção Primavera Verão - 2003
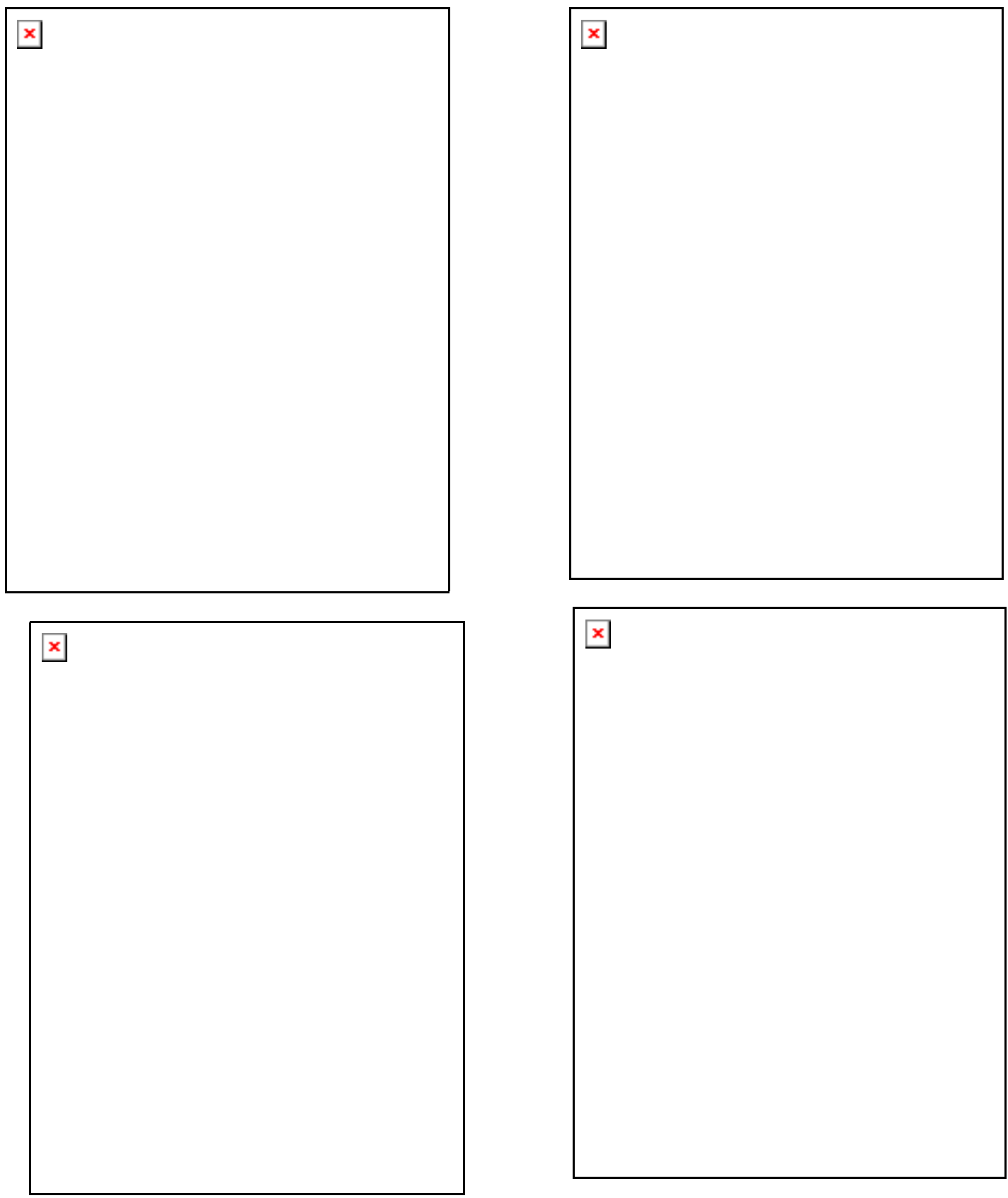

x

Fonte: Arquivos do Depto. de Marketing da Democrata 
Figura 32: Anúncios de Revista - Dia dos Namorados - 2004

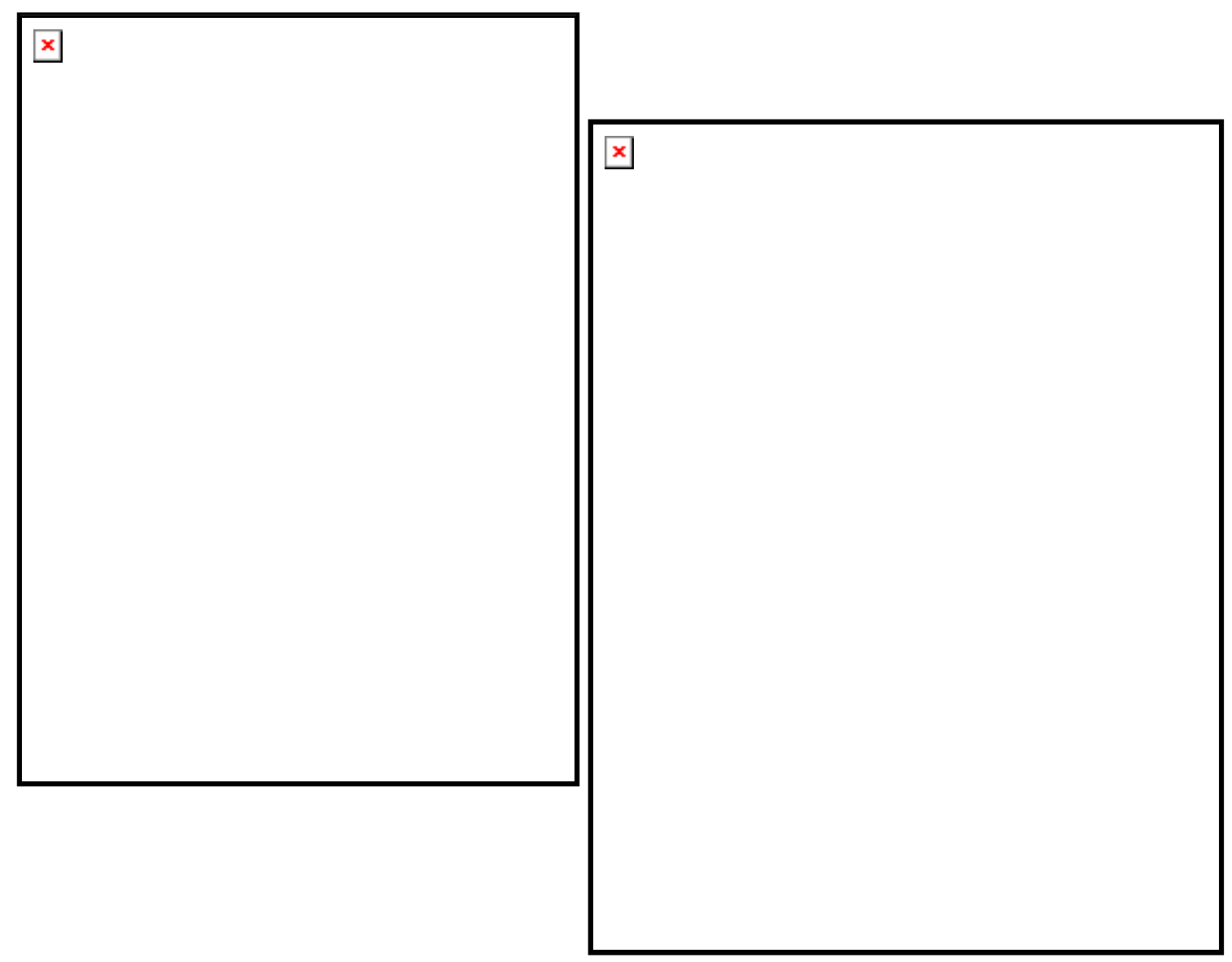

Fonte: Arquivos do Depto. de Marketing da Democrata

Os anúncios apresentados na Figura 32, dão seguimento à linha comunicacional da marca, com a manutenção do tipo testemunhal de Reynaldo Gianecchini. A linguagem visual do anúncio apresenta a fotografia em cores de um casal simulando carícias e a imagem do produto (calçado). A imagem, com apelo sensual, é muito forte e por si própria comunica o objetivo da propaganda: presentear o namorado com o sapato Democrata. Numa sociedade em que a mídia usa o corpo feminino para vender os mais variados produtos, estimulando, além do normal, a sexualidade de seu público, há uma tendência natural por parte da ala masculina em sexualizar todo o conteúdo disponível. O intuito de qualquer campanha é gerar desejo e ação de compra do produto. Dentro das imagens e das correlações oferecidas pelo mix oferecido pela linguagem verbal e visual: música, cores e apelos, o público-alvo 
se sente impelido a consumir aquele produto. De acordo com Corrêa (2002, p. 127), o anúncio utiliza como diferencial a proposição de venda que acentua os aspectos psicológicos, motivando a consumidora em potencial (namorada) à compra, utilizando valores importantes para a mesma como paixão, afetividade, sentimentos etc. - proposição de venda emocional (ESP - emmotional sales proposition).

A sensualidade não possui o condão de mostrar claramente, posto que seja implícita, apenas deixa no ar um toque maroto, com certa malícia, dando ao expectador somente um vislumbre. A grosso modo: 0 erotismo apela para os sentidos conscientes, não permite margem a possíveis dúvidas; ao passo que a sensualidade encobre a vulgaridade disseminada no erotismo por velar e desvelar, tornando-se um contínuo por vir.

O corpo, quando apropriado pela mídia, sobretudo pela mídia publicitária é um corpo sem sujeito, completamente diferente de nossos corpos, em estado natural, anônimos, que são corpos carregados de subjetividade. O corpo na mídia, tende a ser, incontestavelmente, um corpo belo, porém, é um corpo mercadoria, um corpo embalagem, um corpo objeto, enfim, um corpo imagem e, como tal, infalível, atemporal e eterno. A imagem não morre e nós, com nossos corpos enquanto morada do SER, vivemos marcados de subjetividades em sofrimento, subjetividades falíveis, temporais, incoerentes e perecíveis. Os corpos não capturados pela mídia, são suscetíveis a estilhaçamentos, corpos que cheiram, envelhecem, se deterioram, se deformam, adoecem. Corpo, cultura e civilização são simbioses. Se os indígenas primitivos furavam seus corpos, escarificavam a pele, colocavam argolas aqui e ali, devia-se às características e cobranças de sua civilização. Cada uma delas gera seus próprios corpos. Corpos abrigam mensagens, recolhem imagens, abrigam almas, todos os elementos passíveis de expressividade (CAMARGO; HOLF, 2004).

A linguagem verbal apresenta o título Viva amores; a assinatura da marca (logotipo) Democrata e o sub título Dia dos Namorados. 
Figura 33: Anúncio Seqüencial de Revista - Coleção Outono Inverno - 2004

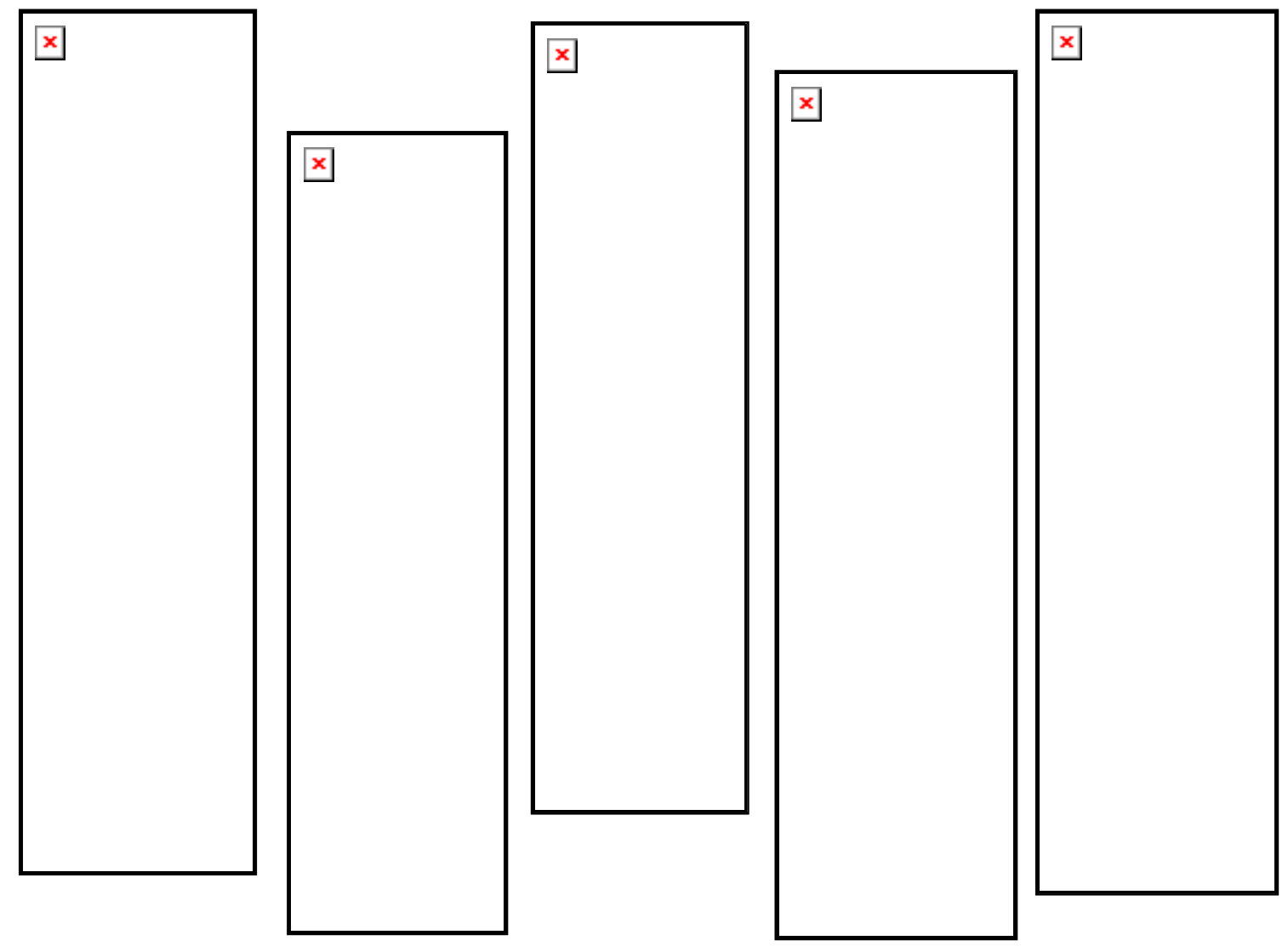

Fonte: Arquivos do Depto. de Marketing da Democrata

A marca utiliza como estratégia de mídia anúncios seqüências. A abertura apresenta o protagonista (garoto propaganda) da marca e os anúncios mostram as linhas dos produtos desenvolvidos para a coleção Outono Inverno 2004. Cada linha de produto foi fotografada em ambientação pré-definida de forma a transportar o leitor à localidade adequada ao gosto e estilo de vida do mesmo. As linhas de produtos apresentam produtos que agradam a todos os estilos: do social ao esportivo. A linguagem verbal apresenta a assinatura da marca com o logotipo Democrata, o nome da linha do produto (Air, trail, Sport) e o título do anúncio Coleção Outono Inverno 2004. 
Figura 34: Anúncios de Revista - Coleção Outono Inverno - 2004
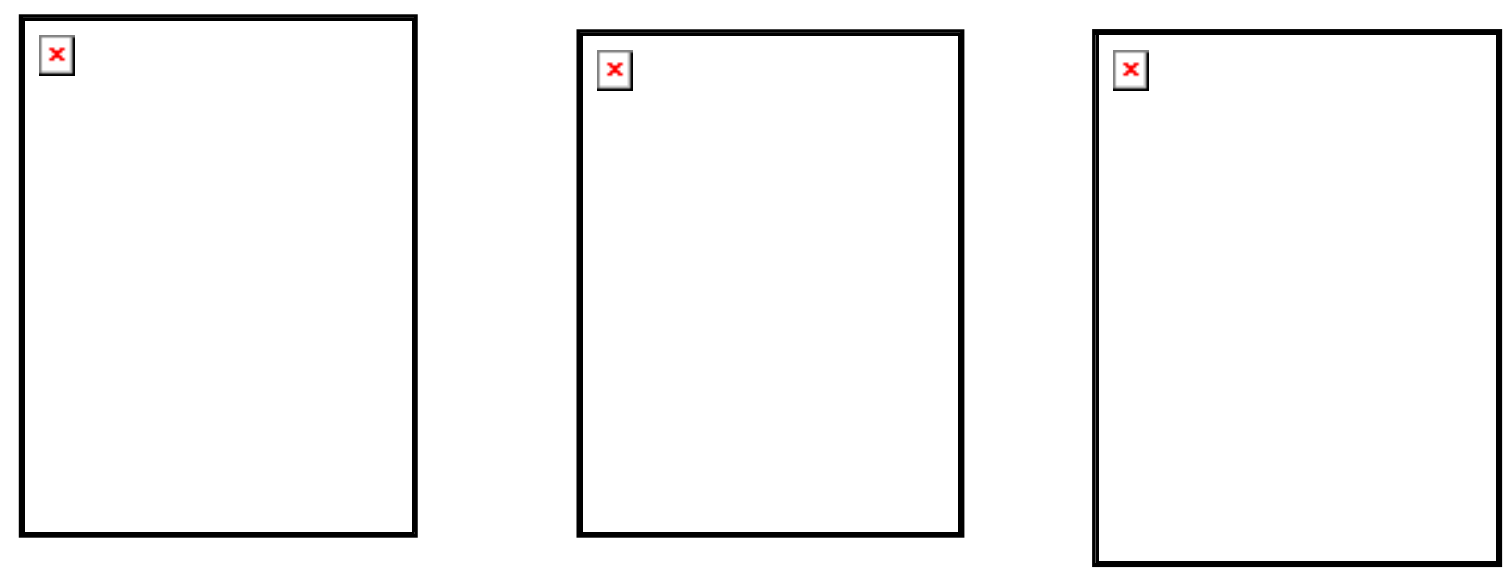

Fonte: Arquivos do Depto. de Marketing da Democrata

A linguagem visual mostra o modelo em diversas situações e vestido para diversas ocasiões. A linguagem verbal apresenta 0 posicionamento da marca (LUPETTI, 2000) composto pela promessa básica: a) como sistema de absorção; b) palmilha Max Memory; c) solado bi-componente; a justificativa a) bolha de ar que absorve o impacto; b) não se deforma; c) leve e resistente; e atributos complementares e imagem desejada - a marca de sapato preferido pelo Reynaldo Gianecchini - a imagem desejada e personalidade do ator é transferida para os produtos da empresa Democrata; a assinatura da marca (logotipo) Democrata, o nome e logotipo da linha de produto (Air Trail, por exemplo) e o slogan O mais confortável da categoria.

Conforme Corrêa (2002, p. 127), o posicionamento de comunicação foi definido como a maneira pela qual o consumidor deve perceber a empresa, produto ou serviço. 
Figura 35: Anúncios de Revista - Dia dos Pais - 2004

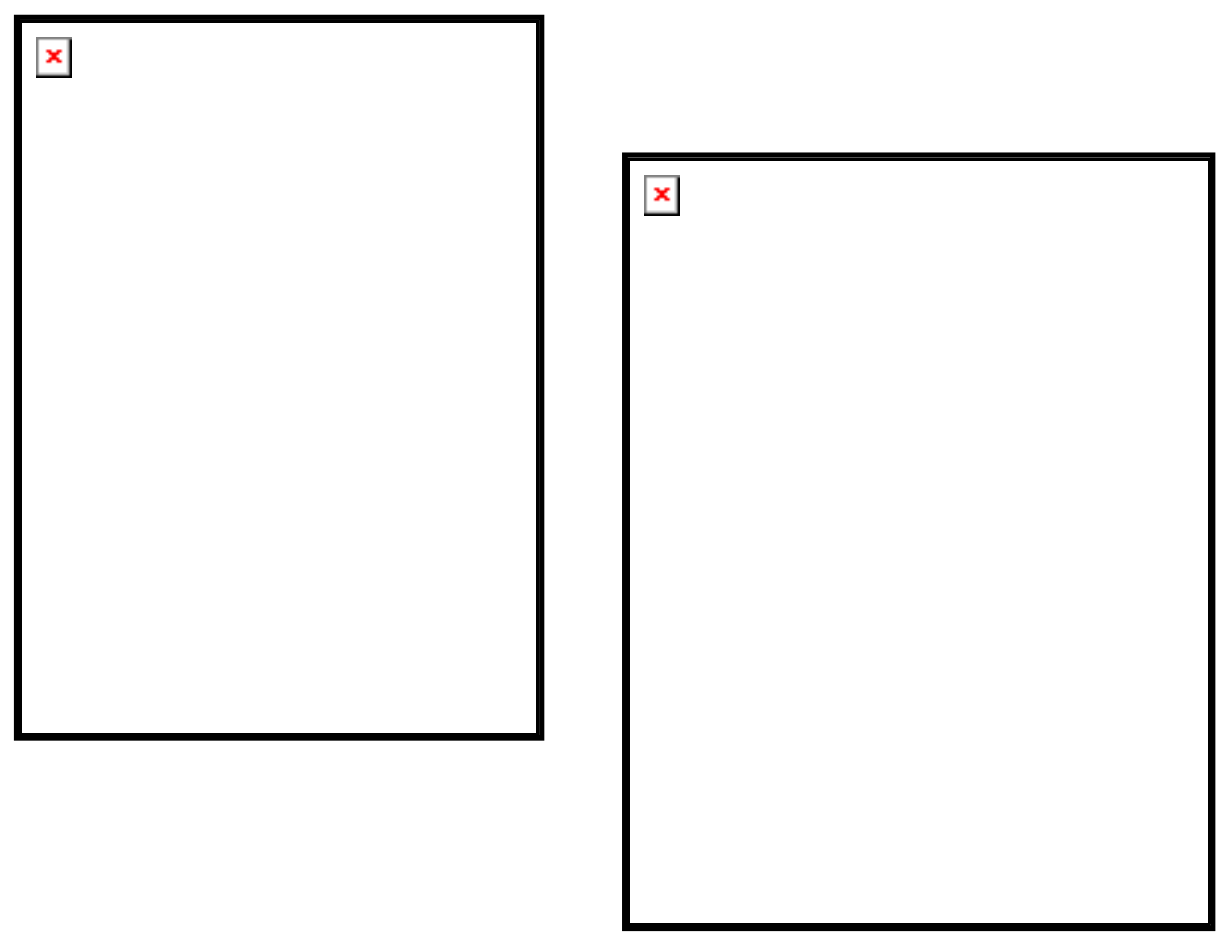

Fonte: Arquivos do Depto. de Marketing da Democrata

A linguagem verbal apresenta o título Viva confiança; a assinatura da marca (logotipo) Democrata e o subtítulo Dia dos Pais. A imagem visual apresenta a fotografia do garoto propaganda em um terno abraço com o filho. A imagem de um abraço comunica uma forma universal de obtenção de contato profundo, físico e afetivo. O gesto de alargar os braços é sinal universal de paz e fraternidade; é um gesto ligado à idéia do abrir-se, à sensação de ficar em contato mais íntimo com o próximo e de estar em disponibilidade para acolhêlo. Um abraço sincero protege. Traduz sentimentos e palavras. Um abraço fraterno deseja paz, harmonia, segurança e amor. A palavra confiança apresenta sentido ambíguo: da confiança existente entre pai e filho que se pode contar em qualquer situação da vida e do crédito inspirado pelo testemunhal (LUPETTI, 2000) do ator Gianecchini, emprestando ao produto e à marca, sua personalidade e beleza. 
Figura 36: Anúncio Seqüencial de Revista - Coleção Primavera Verão - 2004

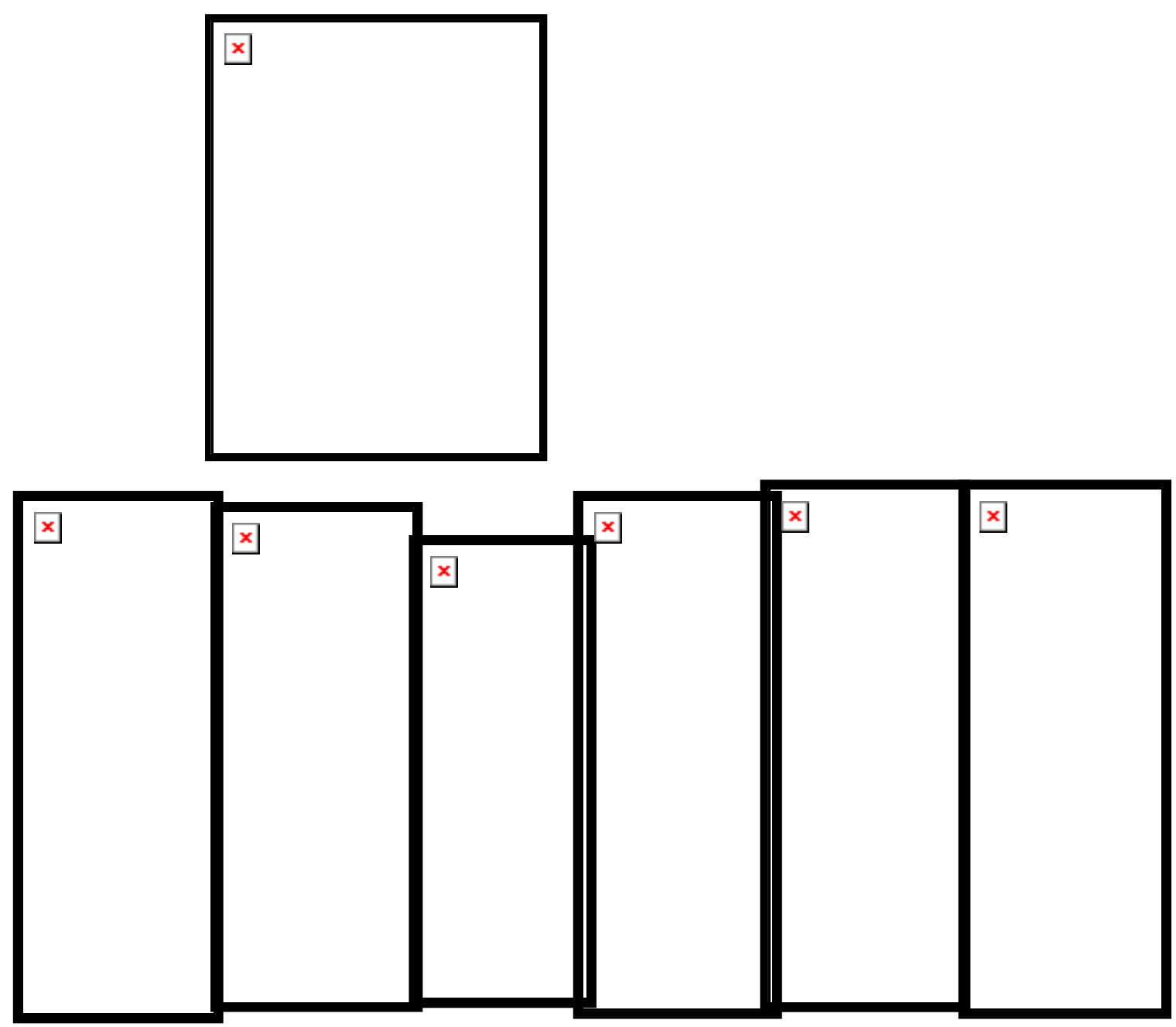

Fonte: Arquivos do Depto. de Marketing da Democrata

A linguagem visual apresenta o garoto propaganda em uma situação em que qualquer homem deseja se transportar: curtindo uma linda paisagem do mar em um carro esporte conversível. Essa imagem dá a conotação de um estilo de vida esportivo, mas sofisticado, de bom gosto e acima de tudo elitizado. Um carro conversível consiste em um sonho de consumo de muitos homens. Os anúncios que se seguem apresentam linhas de produtos diferenciadas para cada ocasião e estilo de vida. A linguagem verbal apresenta a assinatura da marca (logotipo) Democrata e o slogan Onde você estiver (SANDMAN, 2001, 85-86).

Figura 37: Anúncios de Revista - Coleção Primavera Verão - 2004 

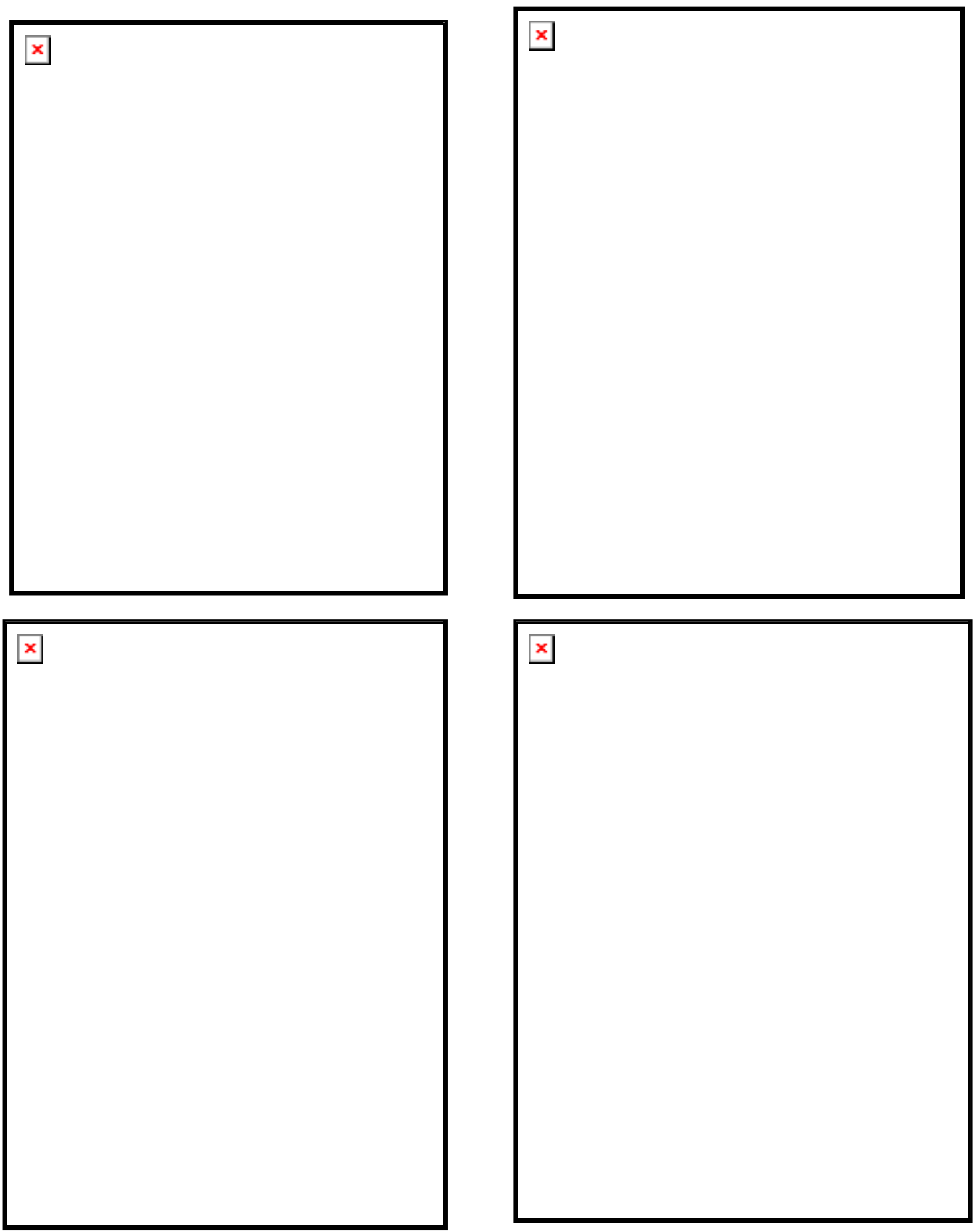

Fonte: Arquivos do Depto. de Marketing da Democrata

A campanha Primavera Verão 2004, é a última ação do contrato entre a empresa e o ator Gianecchini utilizando a estratégia de comunicação testemunhal (Figura 37). Os anúncios mostram o ator em diversas situações: trabalho, lazer e namoro. Apresenta um modelo para cada situação. A linguagem verbal destaca a assinatura Democrata (logotipo) e o slogan 'onde você estiver', passando o significado ao receptor da mensagem que o produto atende a necessidade de estilo, beleza, conforto e modernidade em qualquer programação (SANDMAN, 2001, 85-86). 
Figura 38: Anúncio de Revista - Dia dos Namorados - 2005

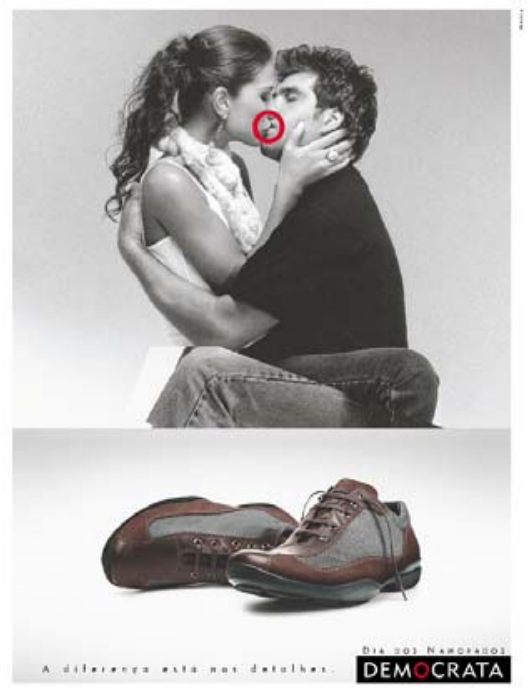

Fonte: Arquivos do Depto. de Marketing da Democrata

O anúncio mostra na parte superior, um casal jovem, anônimo, encenando um beijo com muita sensualidade em preto e branco. $O$ " $O$ " do Logotipo em vermelho sobrepõe o beijo. Na parte inferior o produto em destaque a cores seguido da assinatura Democrata e do título Dia dos Namorados. A utilização da fotografia é um procedimento argumentativo muito comum em textos publicitários. Muitas vezes ela é escolhida pela repercussão afetiva que pode ter o que leva a sua utilização em anúncios onde a linguagem visual e verbal traz a emoção como fator dominante (PERELMAN; OLBRECHTS-TYTECA, 2002, p. 410). 
Figura 39: Anúncios de Revista - Coleção Outono Inverno - 2005

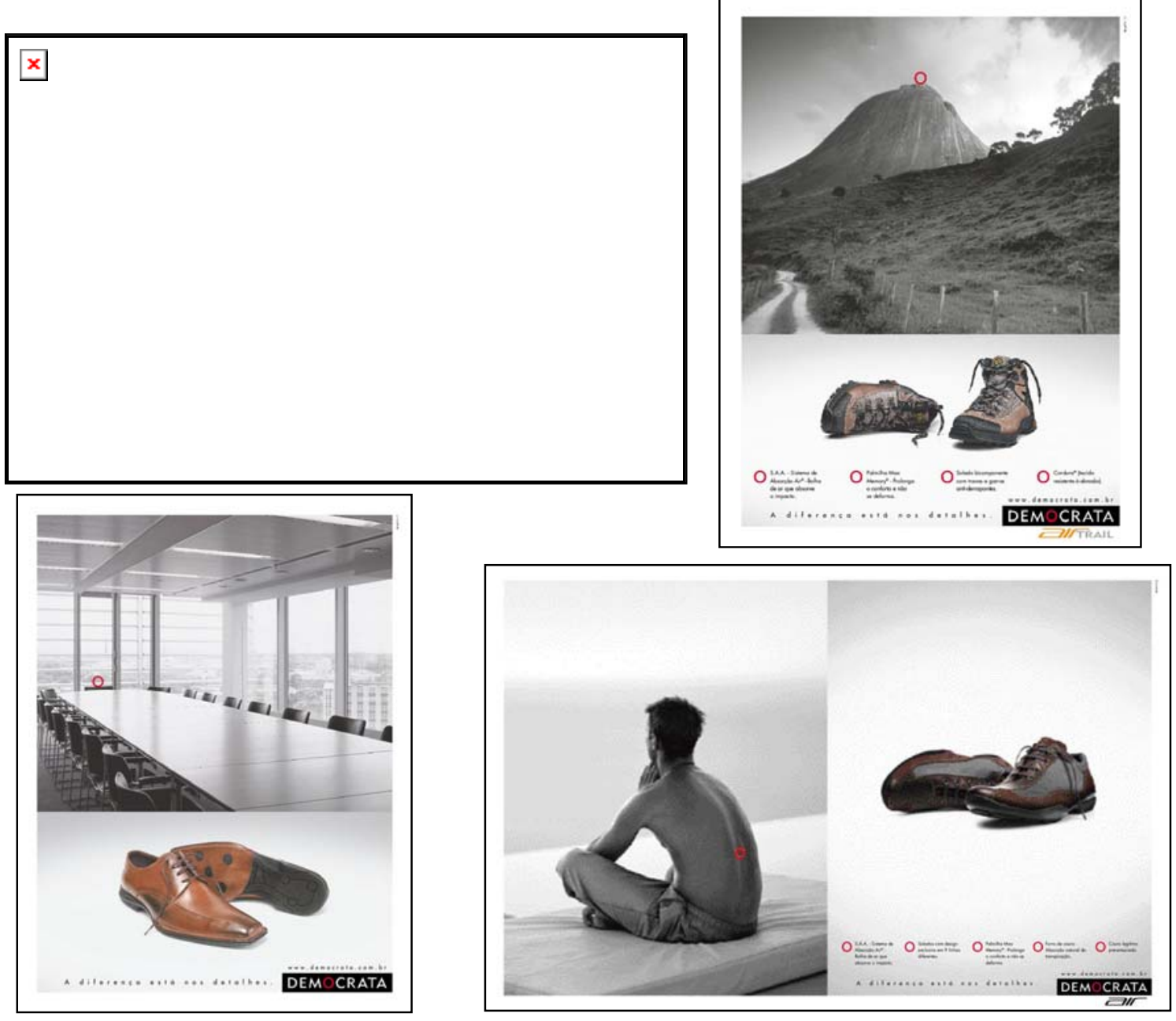

Fonte: Arquivos do Depto. de Marketing da Democrata

O anúncio apresenta o título "Chegou a coleção outono inverno" a assinatura da marca Democrata (logotipo) e o slogan "A diferença está nos detalhes". O posicionamento da marca é explicitado nos anúncios através da linguagem visual, que apresenta no seu íntimo uma narrativa com destaque, no "O" do logotipo em vermelho. No primeiro anúncio, o "O" evidencia o reencontro apaixonado de um casal; no segundo, destaca o alto de uma montanha dando o sentido de um vencedor que conseguiu escalar e chegar ao topo com um calçado Democrata; o mais alto cargo de uma corporação, com destaque ao lugar da Presidência; e o jovem que apresenta um físico perfeito com destaque na coluna, pois um bom calçado como o Democrata, previne problemas que poderão surgir como o da coluna, por exemplo. 
A ilustração ou foto tem a função de reforçar a adesão a uma regra conhecida e aceita. Fornecendo casos particulares que esclarecem o enunciado geral, mostram o interesse deste através das aplicações possíveis, aumentando-lhe a presença na consciência (CARRASCOZA, 2004, p. 124).

Os textos dos anúncios apresentados assumem a forma de histórias, que através da narrativa - implícita - expõe o posicionamento da marca, passando a mensagem ao seu público-alvo com a finalidade de despertar emoções, para que o mesmo seja persuadido e efetive a compra do produto anunciado.

A propaganda impressa com textos dionisíacos explora o procedimento do uso da ilustração, pois em virtude da variedade e das características específicas de tantos produtos e serviços que brotam na sociedade de bens afluentes, e a necessidade de promover suas diferenças, o discurso acaba por se apoiar numa dessas diversas maneiras de ser ou de fazer (Idem, p. 125).

Figura 40: Anúncios de Revista - Dia dos Pais - 2005

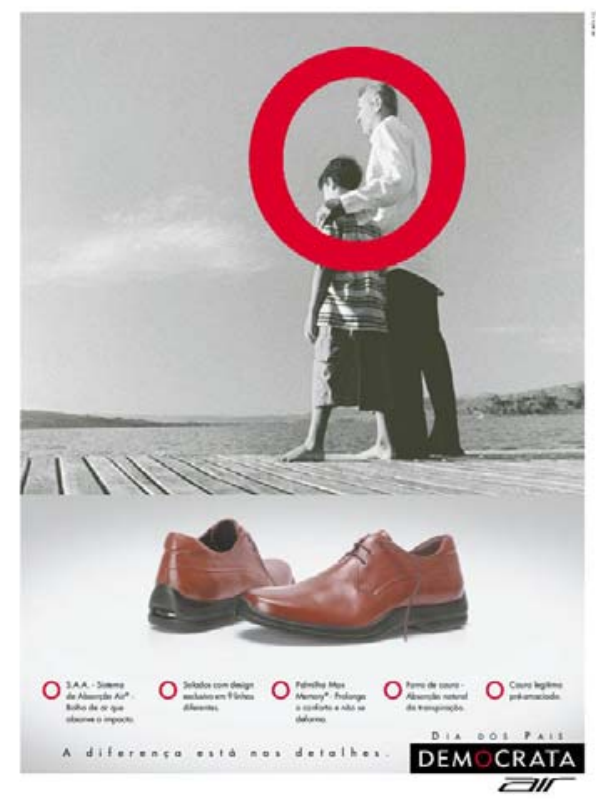

Fonte: Arquivos do Depto. de Marketing da Democrata

A linguagem verbal do anúncio apresenta o título "Dia dos Pais"; o texto, apresentando os benefícios do produto em forma de tópicos. Alguns aspectos sintáticos são característicos da linguagem da propaganda, como a topicalização que ocorre quando o objeto direto não vem no seu lugar correto (depois do verbo), ganhando destaque ou ênfase (SANDMAN, 2001). A assinatura da marca Democrata e o slogan "A diferença está nos detalhes". A 
linguagem visual apresenta como ilustração (CARRASCOZA, 2004) a figura de um pai e uma criança. O "O" do logotipo em vermelho evidencia todos os detalhes de forma, primeiramente emotiva representando o amor e a fraternidade da relação entre pai e filho e em segundo lugar, de forma racional destacando o texto que apresenta os benefícios do produto.

Figura 41: Anúncios de Revista - Primavera Verão - 2005
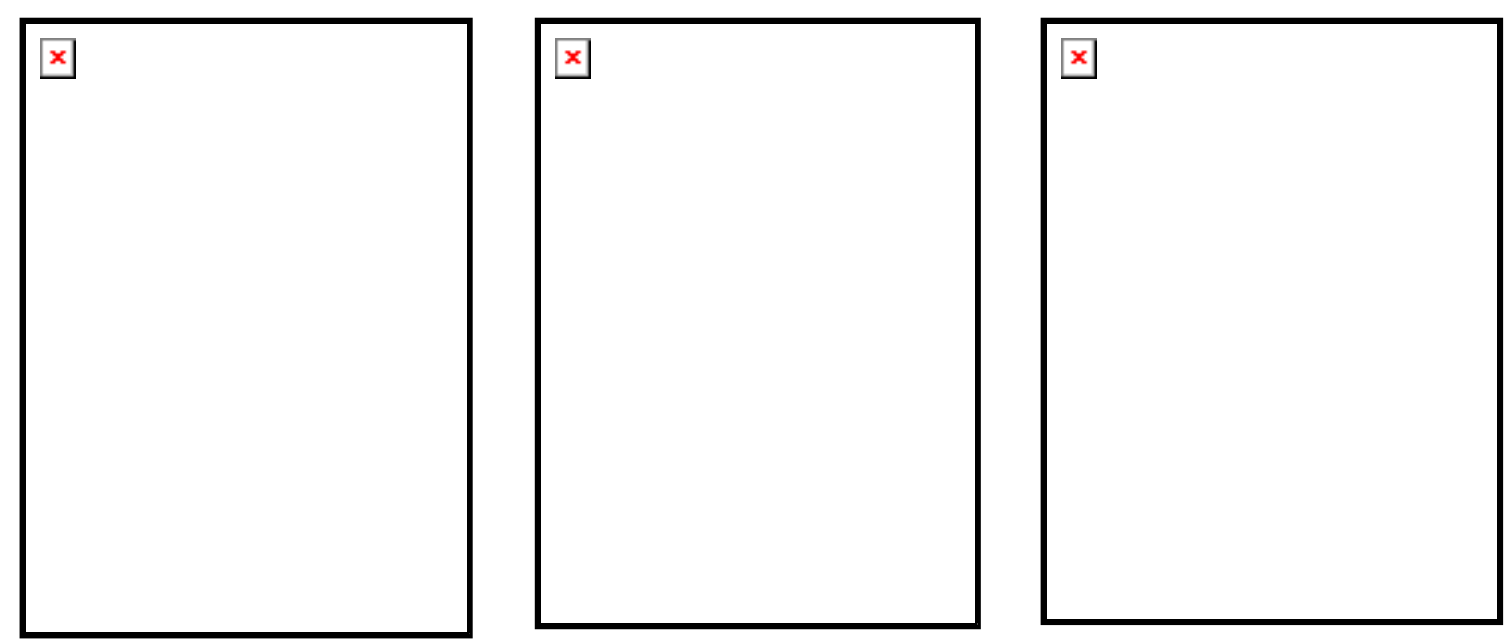

Fonte: Arquivos do Depto. de Marketing da Democrata 
Figura 42: Anúncios de Revista - Primavera Verão - 2005
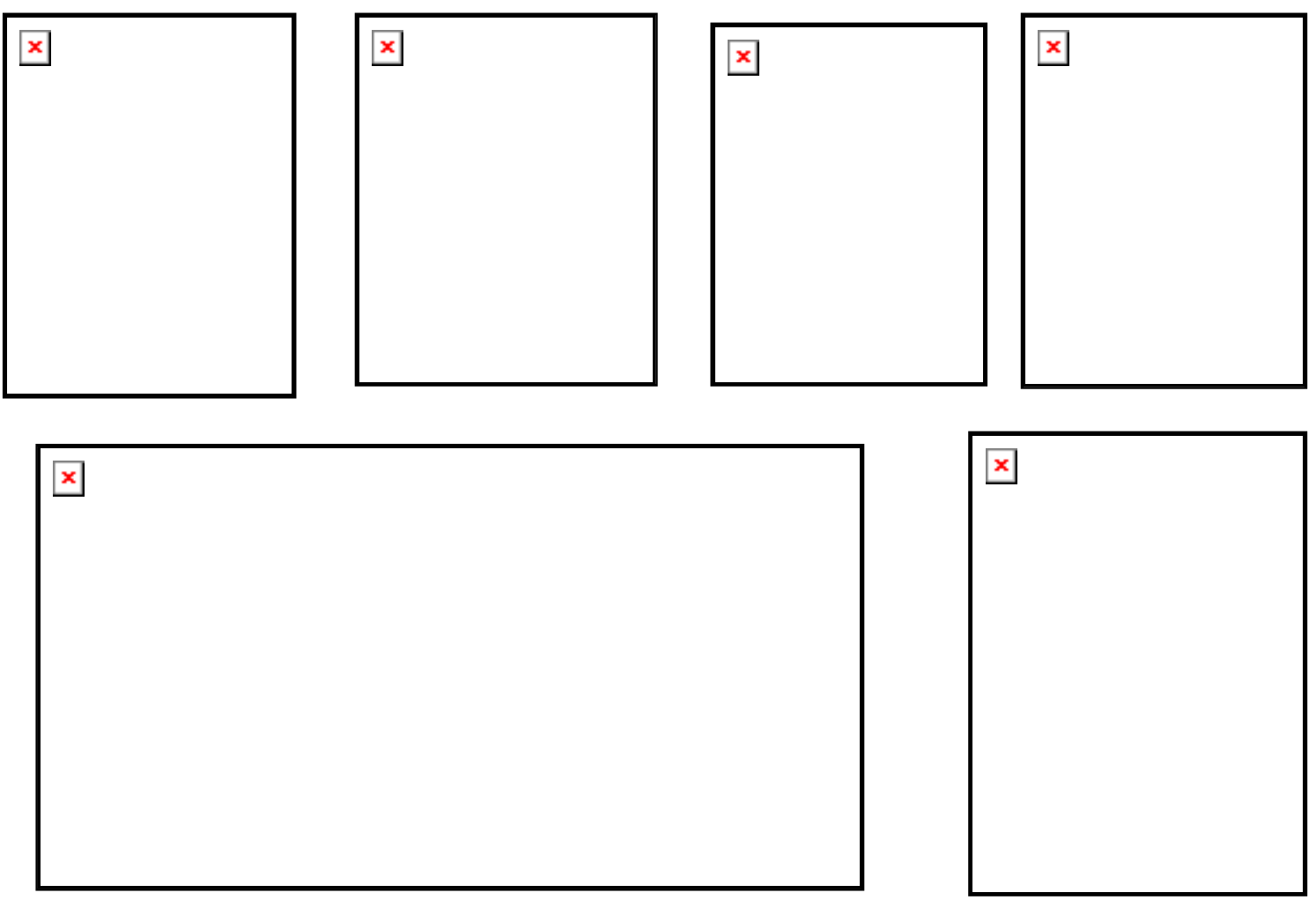

Fonte: Arquivos do Depto. de Marketing da Democrata

A linguagem verbal do anúncio dois (Figura 41) apresenta o título "Aproveite o ar da praia, o ar das montanhas e o ar do sapato". Nos demais anúncios (Figura 41 e 42) o texto apresenta os benefícios do produto em forma de tópicos. A assinatura da marca Democrata e o slogan "A diferença está nos detalhes".

A linguagem visual apresenta a continuidade da campanha anterior, com a utilização de ilustrações como sentido implícito de narrativas, para que o consumidor se identifique com as situações apresentadas nos anúncios. O "O" do logotipo, aparece nesses anúncios, na forma de metáfora no lugar do sol que sugere várias interpretações, como: essencial como a luz do sol; brilho único; força e resistência; beleza ímpar; natural etc (SANDMAN, 2001). 
Figura 43: Anúncios de Revista - Dia dos Namorados - 2006

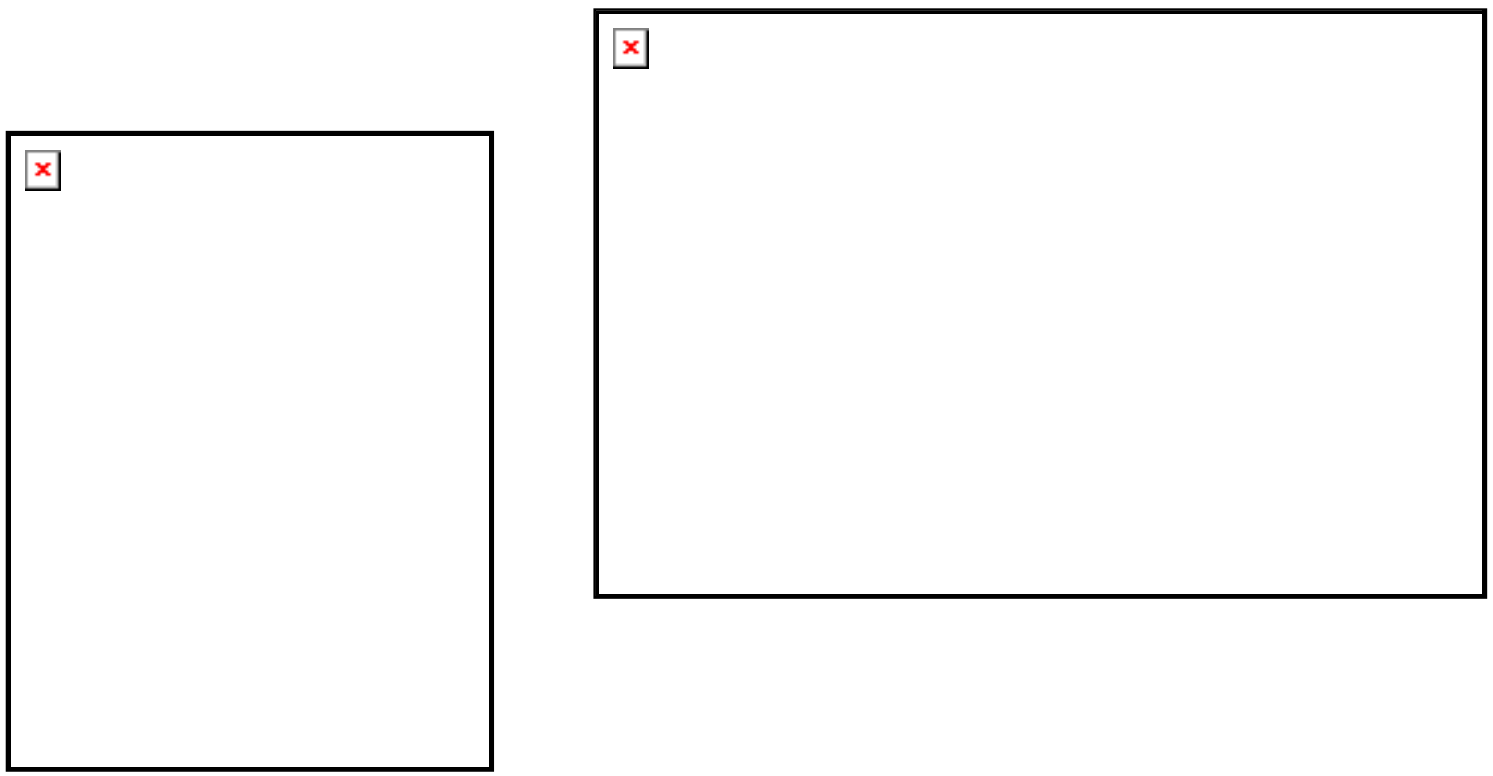

Fonte: Arquivos do Depto. de Marketing da Democrata

Nesta campanha de comunicação, a estratégia utilizada pela empresa é considerada pioneira para o setor: a valorização do olhar feminino na decisão de compra de calçados masculinos. Para tal, a escolha da apresentadora de TV e Modelo Adriane Galisteu como garota propaganda do Dia dos Namorados (LUPETTI, 2000). Conforme Andrea Rinaldi, gerente de marketing da Democrata:

"a nova coleção será lançada com uma nova estética
conceitual, onde as peças remetem a um clima de
sedução, revelando aos homens o que há por trás do olhar
feminino (PRESS RELEASE, 2006)".

A linguagem verbal do anúncio (Figura 43) apresenta o título "Dia dos Namorados"; o texto "Design moderno e couro aveludado, conferindo um estilo único ao produto. A assinatura da marca Democrata e o slogan "A diferença está nos detalhes". Na parte inferior da foto a legenda "Adriane Galisteu para Democrata.

$\mathrm{Na}$ escolha do testemunhal de uma personalidade, como Adriane Galisteu, o elemento suasório principal (presentificação) é o apelo à autoridade e ao prestígio que a mesma empresta à marca. Os testemunhais se apóiam em narrativas em tom confessional, que denotam sinais de sinceridade e de 
lealdade por parte da personalidade, que aumenta a confiança dos receptores da mensagem (CARRASCOZA, 2004, p. 122).

A linguagem visual utiliza como ilustração o produto e a foto de Adriane Galisteu. O "O" do logotipo, destaca de forma dinâmica detalhes do design do produto e dos olhos de Adriane Galisteu.

Figura 44: Anúncios de Revista - Coleção Outono Inverno - 2006
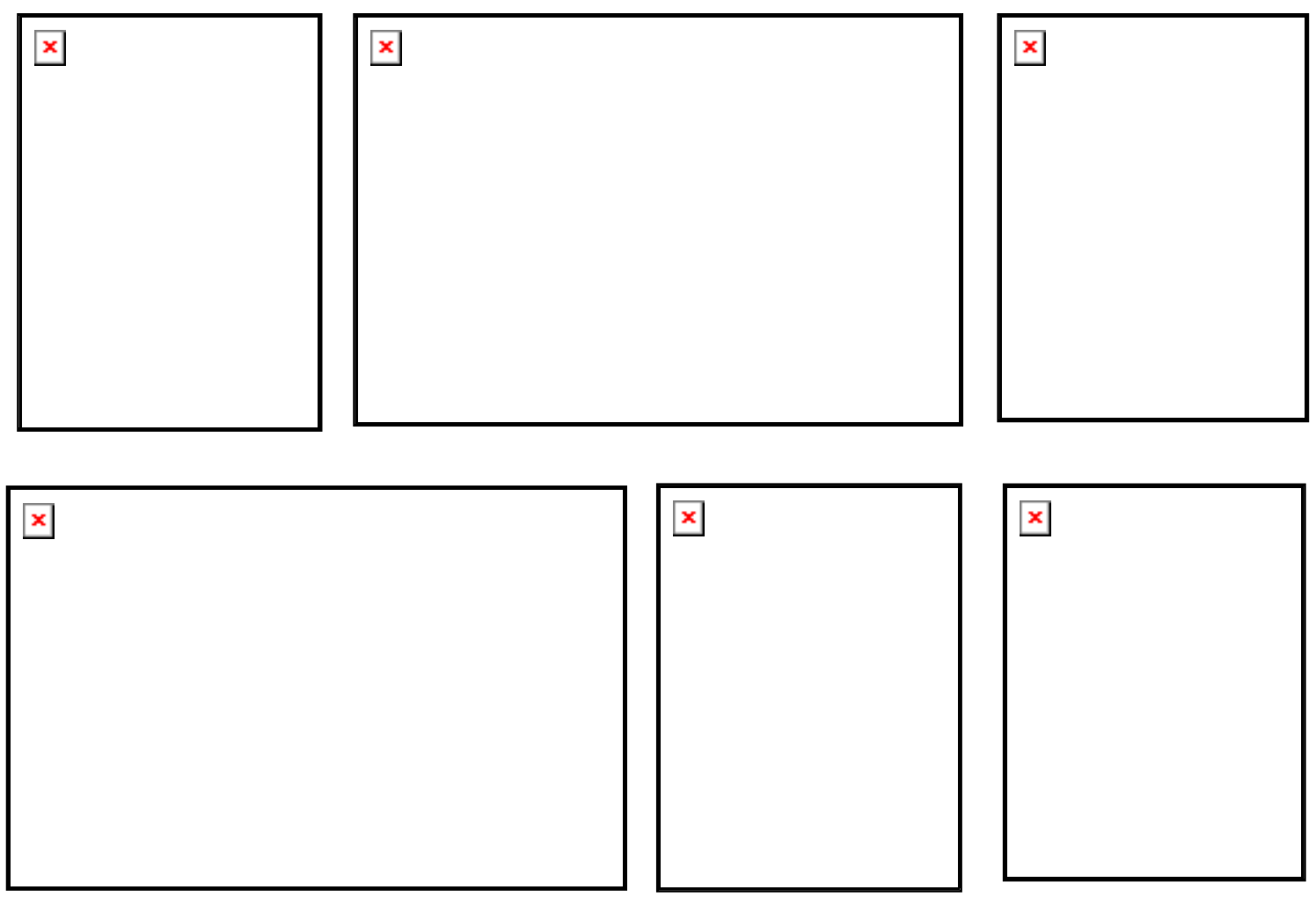

Fonte: Arquivos do Depto. de Marketing da Democrata

A campanha de comunicação da linha Outono Inverno 2006 da Democrata é inovadora utilizando a figura feminina na campanha levando em consideração a grande influência da mulher na compra do calçado masculino.

"Apesar de o homem ter aprendido muito sobre moda nos últimos anos, e ter adquirido um senso de escolha antenado com as tendências de cada estação, a mulher ainda exerce um papel fundamental". As razões são bem definidas: primeiro, o homem escuta os conselhos de moda e estilo das mulheres; depois, ele compra porque sabe que ela irá gostar, ou seja, compra para encantar e seduzir a mulher com o visual; e por fim, são muitas as mulheres que compram o calçado para seus maridos, namorados e familiares afirma Andréa Rinaldi (PRESS RELEASE, 2006)". 
De acordo com esta estratégia, a linguagem visual apresenta nas peças de propaganda, a figura do rosto de uma linda mulher sedutora que olha nos olhos do receptor e o produto, nas variações de linhas e cores. A linguagem verbal do anúncio apresenta como texto as referências e os benefícios do produto destacados pelo "O" seguidos pela assinatura da marca Democrata (logotipo); a linha do produto "Air" e o slogan "A diferença está nos detalhes".

Os anúncios apresentam a narrativa implícita da compra do produto para seduzir a mulher. Esse recurso é evidenciado na fase da manipulação, onde a personagem em destaque no anúncio tenta convencer o leitor ou público da Democrata a fazer algo (comprar o produto anunciado) utilizando a sedução, na qual o manipulador busca a persuasão ressaltando as qualidades do manipulado (CARRASCOZA, 2004, p. 104).

\subsubsection{Calçados Sândalo}

A Indústria de Calçados Sândalo tem como estratégia de comunicação a integração das ferramentas propaganda e promoção de vendas. Utiliza para divulgar seus produtos: anúncios nas revistas Playboy, Vip, Época e Lançamentos; Outdoors em campanha nacional nas cidades com mais de 150.000 habitantes. Nos últimos quatro anos, foram intensificadas as ações nos pontos de vendas (lojas multimarcas). Foram desenvolvidos os materiais: catálogos, banners, displays, sinalizadores e ações de incentivo junto à força de vendas.

Foram relacionados neste estudo, anúncios de revistas, outdoor e catálogos desenvolvidos no período de 2002 a 2005.

Figura 45: Outdoor $N^{0} 1-2^{\circ}$ Semestre 2002

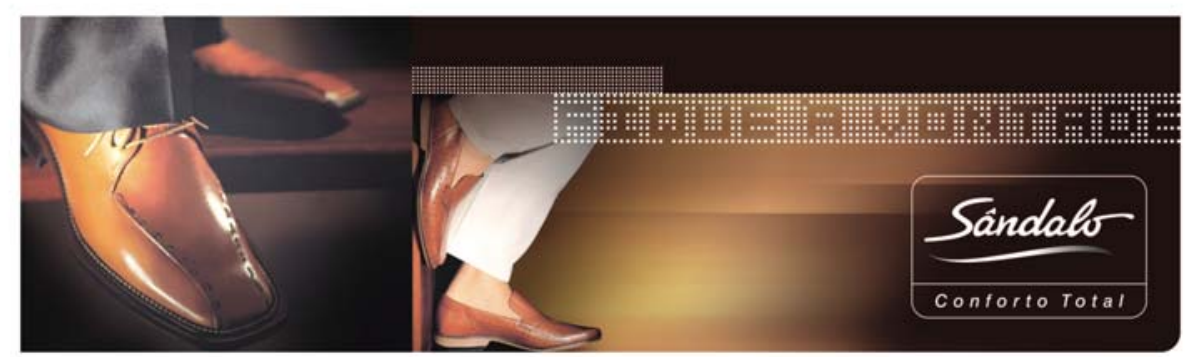

Fonte: Arquivo Depto. de Marketing dos Calçados Sândalo. 
Figura 46: Anúncio de revista No $1-2^{\circ}$ Semestre 2002

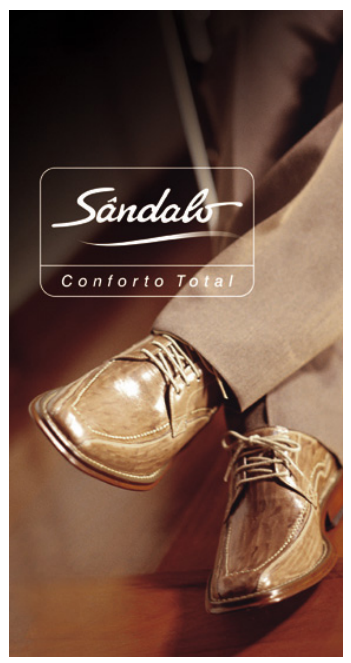

Fonte: Arquivo Depto. de Marketing dos Calçados Sândalo.

Figura 47: Outdoor $N^{\circ} 2-2^{\circ}$ Semestre 2002

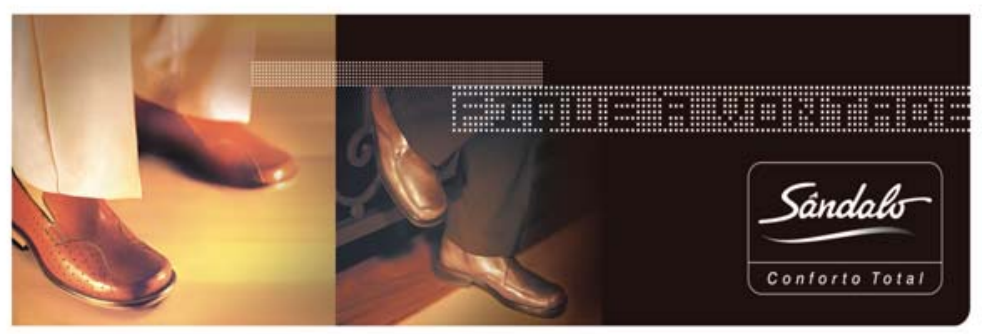

Fonte: Arquivo Depto. de Marketing dos Calçados Sândalo.

Figura 48: Anúncio de revista № $2-2^{\circ}$ Semestre 2002

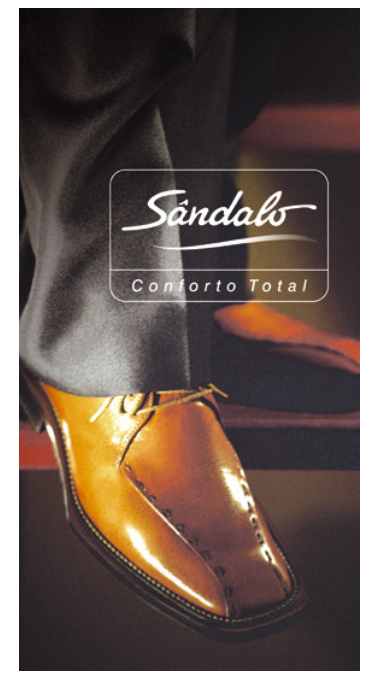

Fonte: Arquivo Depto. de Marketing dos Calçados Sândalo. 
As Figuras 45, 46, 47, 48 apresentam as peças de divulgação da coleção 2002 de estilo social da marca, em anúncios de revistas e mídia exterior - Outdoor. A linguagem visual apresenta um layout sofisticado, tradicional, com exposição dos produtos, deixando a mostra pequena parte da perna do usuário. Apresenta um contraste entre o fundo escuro e a tonalidade do produto. O efeito de brilho utilizado nas fotos valoriza e destaca o produto. Remete o usuário ao brilho ou sucesso que o produto lhe proporcionará. A linguagem dirige a mensagem ao perfil de um executivo, um homem de classe. A postura do anunciante está orientada para a apresentação do produto com destaque em seus atributos: qualidade, estilo, design, conforto. Conforme Bakthin (1992 b), o estabelecimento de vínculos do emissor é interpretado através da consciência dos receptores, e a compreensão estabelece o contato e a projeção do receptor.

A linguagem verbal apresenta a assinatura da marca "Sândalo"; o slogan "Conforto total" e o título (outdoor) "Fique à vontade". Marca tradicional no mercado de calçados a Sândalo está presente na mente do consumidor. A construção de uma marca requer trabalho árduo e muita persistência. $O$ consumidor está cada vez mais exigente e, diante disso, percebe-se a necessidade de aperfeiçoar o produto e oferecer mais serviços, agregando valor ao mesmo, além de ter atitudes positivas em relação à responsabilidade social, ambiental e profissional. Para obter a credibilidade e longevidade de uma marca é fundamental que a empresa tenha capacidade de aliar design, qualidade e preço buscando atender, ou até mesmo superar, as expectativas dos consumidores (RIBEIRO, 1999). Analisando as empresas detentoras de marcas fortes, iniciaram com dificuldade, cresceram e alcançaram o sucesso, baseadas no produto que é a força maior de uma empresa. Criar e gerenciar uma marca adequadamente não depende exclusivamente dos recursos investidos, mas principalmente da formulação estratégica do marketing mix: composto de produto, preço, distribuição e logística e comunicação (SAMPAIO, 2002, p. 25).

A marca Sândalo é reconhecida como detentora de produto com qualidade, conforto e status. Portanto, a assinatura da mesma nas peças 
publicitárias, apresenta o aval de uma empresa séria e comprometida que entende de produto e que oferece o melhor.

No Título do outdoor "Fique à vontade" utiliza a técnica da simplicidade estrutural (SANDMAN, 2001), deixando elementos subtendidos apenas na análise do contexto onde o receptor subentende o produto como "gostoso no pé", "confortável", "o usuário sente-se à vontade", reforçado pela linguagem visual que apresenta o modelo em movimento: caminhando; descendo escadas ou simplesmente de pernas cruzadas em uma atitude de relaxamento.

O slogan comunica ao receptor a essência do atributo principal do produto: o conforto. O consumidor não necessita de abrir mão do seu bem estar, o produto proporciona a elegância sem abrir mão do conforto. De tempos em tempos alguns vocábulos, termos ou expressões são renomeados e iluminam a sua semântica original. Atualmente, conforto vem sendo usado indiscriminadamente. Designa e relaciona tudo aquilo que está adequado e adaptado, que consola e proporciona prazer, que é competente e apropriado ou ainda, que é convenientemente oportuno. Sob a perspectiva dos valores humanos busca a comodidade, a adequação e a expressividade (SCHMID, 2005). Conforto tem sido o principal tema em destaque nas feiras internacionais de calçados. Os calçados confortáveis têm sido a preferência dos consumidores jovens, principalmente, influenciando nos modelos e design atuais. O conforto tem sido visto mais sob o aspecto do subjetivo e considerado como difícil de ser mensurado. De forma simplista, define-se que tudo que contribui para o bem estar do pé se chama conforto. Nas peças publicitárias em estudo, apresentam subliminarmente a analogia da palavra conforto com comodidade. Resume-se à palavra conforto a gama de atributos e benefícios agregados ao produto. O posicionamento do anunciante define que o calçado oferece conforto quando o mesmo não expõe os pés a enfermidades ou deformações. Utiliza-se a palavra "conforto" para a valorização dos calçados. A biomecânica estuda a ação do calçado, desde a sensação de bem-estar das pessoas até as suas relações com as funções vitais do organismo. Partindo-se da compreensão dos conceitos entre calçado, bem-estar do indivíduo, 
manutenção da saúde e da segurança, é que são trabalhados os fundamentos para a fabricação do calçado em condições de trabalho, de lazer, de esporte e de atividades em geral. Para formatar o calçado confortável, tem-se que partir do conceito de que todo o calçado deve atender às necessidades do indivíduo. Um calçado confortável possui características como bom calce; não prejudicar os pés e manter a integridade dos mesmos; dar uma boa proteção aos pés; oferecer segurança ao andar; preservar a saúde do usuário; ser adequado à atividade que se destina; não alterar os parâmetros da marcha; promover uma adaptação amigável aos ambientes; e permitir aos seus usuários atenderem aos princípios psíquicos relativos à aparência de sua personalidade (ÀVILA, 2006). 
Figura 49: Outdoor $\mathrm{N}^{\circ} 1-1^{\circ}$ Semestre 2004

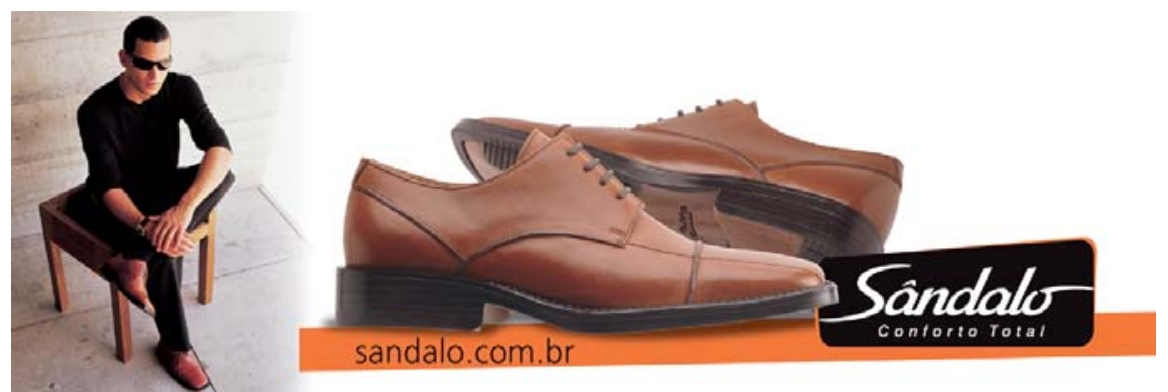

Fonte: Arquivo Depto. de Marketing dos Calçados Sândalo.

Figura 50: Anúncio de revista № $1-1^{\circ}$ Semestre 2004

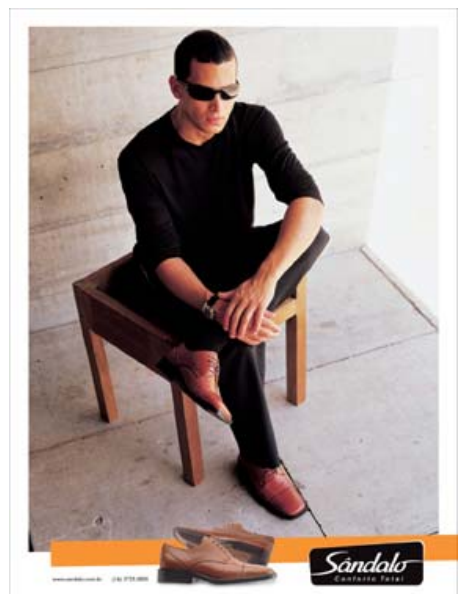

Fonte: Arquivo Depto. de Marketing dos Calçados Sândalo.

Figura 51: Anúncio de revista Nº $2-1^{\circ}$ Semestre 2004

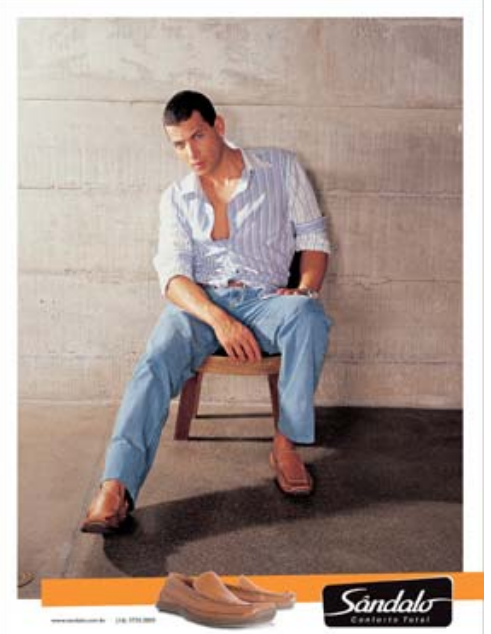

Fonte: Arquivo Depto. de Marketing dos Calçados Sândalo. 
O posicionamento e o conceito do produto são expressos através dos elementos que compõem a linguagem visual. As figuras 48,49 e 50 destacam na em primeiro plano, o produto; seguido do modelo, usando o produto. No outdoor e no anúncio $n^{\circ} 1$, o modelo representa o perfil de um jovem elegante e bem sucedido sentado em uma banqueta com a perna esquerda cruzada sob a direita, expressando uma postura muito confortável e com as duas mãos entrelaçadas sob o joelho. A composição do vestuário é toda na cor preta, inclusive os óculos (que apresenta a conotação de sofisticação, prestígio e poder) contrastando com o sapato usado. $\mathrm{Na}$ linguagem verbal apresenta a assinatura da marca; o slogan "conforto total" e o endereço eletrônico. No anúncio $n^{\circ} 2$, o modelo está sentado de forma despojada em uma cadeira, com as pernas jogadas para frente, indicando outra vez a postura confortável, o braço direito sob a perna direita e o braço esquerdo segurando a cadeira, vestindo um traje esportivo com destaque no sapato que calça. Na linguagem verbal apresenta a assinatura da marca; o slogan e o endereço eletrônico.

Figura 52: Anúncio de revista № $3-1^{\circ}$ Semestre 2004

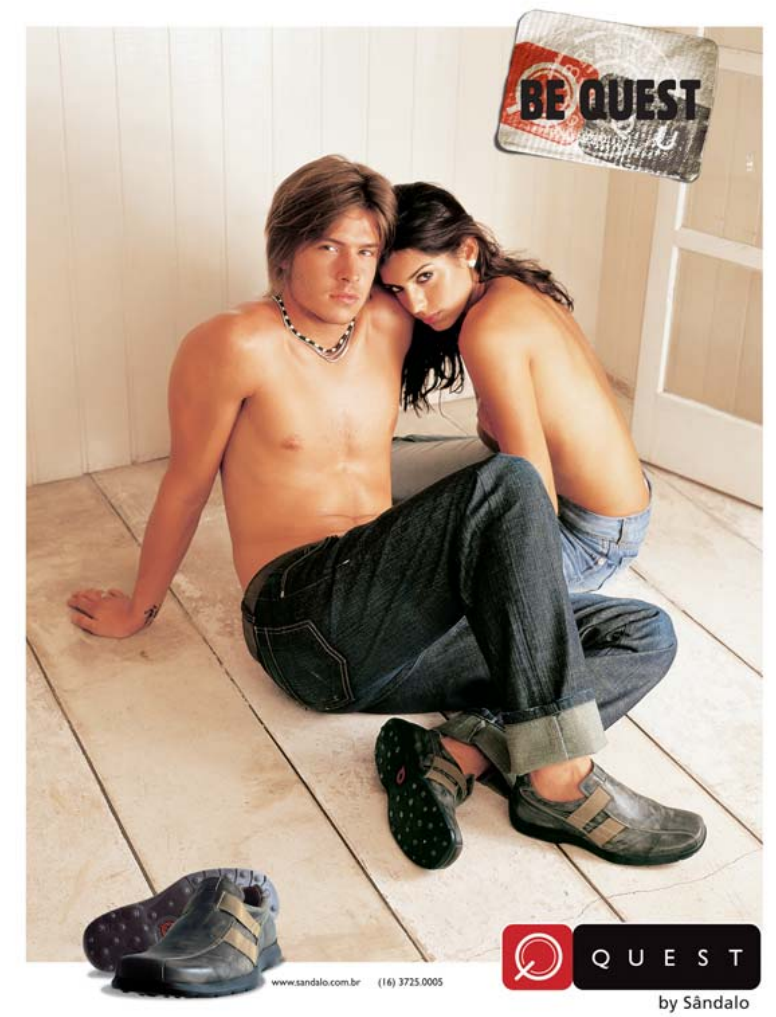

Fonte: Arquivo Depto. de Marketing dos Calçados Sândalo. 
Esse anúncio apresenta uma nova proposta, a linha jovem e esportiva dos calçados denominada Quest. A linguagem visual explora a sexualidade. Apresenta como protagonistas do anúncio um casal de jovens, um de frente para o outro, com expressão facial séria, vestindo apenas calças jeans e o sapato da linha. A exploração do sexo na propaganda é um fenômeno que ultrapassa as fronteiras do Brasil. É difícil dissociar desejo, publicidade e consumo. Quando se quer conquistar o consumidor, a sensualidade é um recurso quase infalível. O psicanalista Sigmund Freud foi o pioneiro a reconhecer - e a explicar - o poder mobilizador do sexo nas pessoas. Para Freud, há uma quantidade de energia psíquica em cada indivíduo. Essa energia, chamada por ele de libido, reflete o desejo sexual que é comum a todos. É a vontade de agradar e ser agradado, de amar e ser amado. Santi (SORDAS, 2006) identifica dois tipos de motivação sexual: "A pessoa adquire um produto para encantar o outro ou para se satisfazer". Assim, um rapaz pode comprar um sapato para chamar a atenção das garotas - ou para agradar a si mesmo. Na rotina atribulada das pessoas, uma propaganda mais sensual funciona como um convite ao relaxamento. Em 1954, Abrahm Maslow propôs a célebre "pirâmide da hierarquia das necessidades humanas". Na base aparece aquilo que é fundamental para a sobrevivência do indivíduo - as necessidades fisiológicas. "O sexo é tão importante para qualquer pessoa quanto saciar a sede e matar a fome" (KOTLER, 2000, p. 194). A sexualidade na propaganda seduz, envolve, provoca, gera polêmica, e quando não ofende, vende.

A linguagem verbal mostra os textos o emprego de empréstimo lingüístico: Be Quest simbolizando a etiqueta da linha de produtos; Quest como assinatura da linha; e a palavra By Sândalo, marca reconhecida de calçados. O sentido da utilização de vocabulário inglês é que o que vem do exterior é melhor, moderno, valoriza o produto, como tendência mundial. 
Figura 53: Anúncios Revista Couro Moda 2004

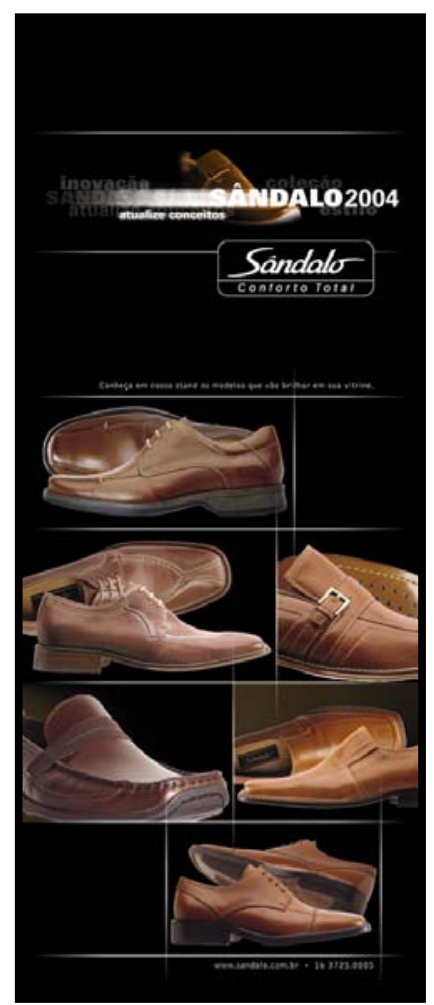

A

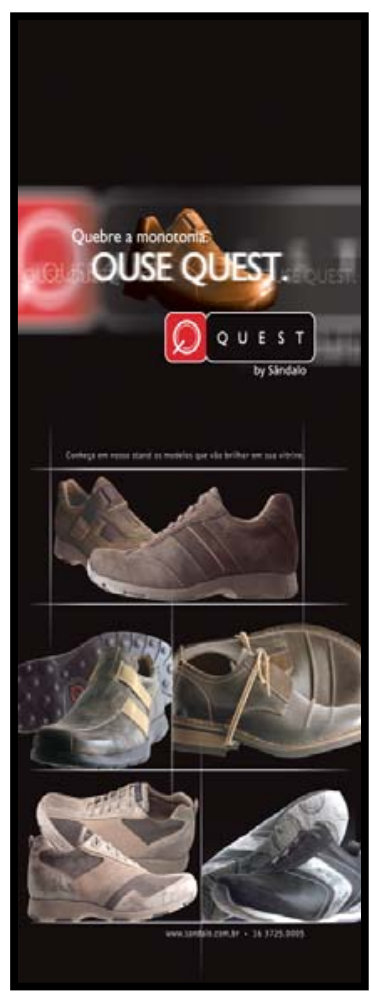

B

Fonte: Arquivo Depto. de Marketing dos Calçados Sândalo.

A linguagem visual do anúncio da figura 53-A apresenta seis modelos da linha tradicional sobrepostos em fundo preto, com título, assinatura e slogan na parte superior, com efeito, de movimento. A linguagem verbal apresenta: título - Inovação Sândalo - Coleção Estilo - Atualize conceitos (apresentam a postura de uma marca fortalecida e rejuvenescida); assinatura Sândalo. Slogan: Conforto total. - Texto: Conheça em nosso stand os modelos que vão brilhar em sua vitrine. O texto convida o logista a visitar o estande da Empresa Sândalo na feira para conhecer e comprar a coleção que será um sucesso em vendas nas lojas.

A linguagem visual do anúncio da figura 53-B apresenta cinco modelos da linha Quest no mesmo padrão, sobrepostos em fundo preto, com título, assinatura e slogan na parte superior. A linguagem verbal apresenta: título - Quebre a monotonia, Ouse Quêst - proposta ao lojista para que saia da rotina e abra espaço para a nova linha jovem da Empresa Sândalo. A palavra ouse apresenta duplo sentido refere-se ao sentido denotativo de ousar e 
inovar, como também sugere o trocadilho use Quest; Assinatura: Quest by Sândalo; texto: Conheça em nosso stand os modelos que vão brilhar em sua vitrine (SANDMAN, 2001).

Figura 54: Anúncio de Revista Francal 2004

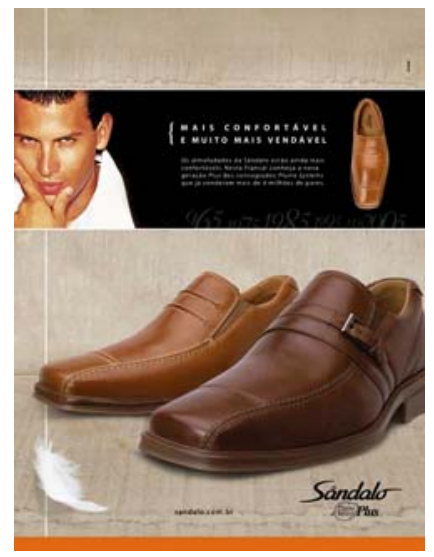

Fonte: Arquivo Depto. de Marketing dos Calçados Sândalo.

A figura 54 apresenta a linguagem verbal: o título - Mais confortáveis e muito mais vendável; texto - Os almofadados da Sândalo estão ainda mais confortáveis. Nesta Francal conheça a nova geração Plus dos consagrados Plume Systems que já venderam mais de 4 milhões de pares; assinatura - Sândalo Plus e endereço virtual: www.sandalo.com.br. A argumentação do anúncio posiciona a linha Plus junto ao revendedor com a promessa de produtos confortáveis e vendáveis. A justificativa apresenta o lançamento da linha, que já tem tradição de sucesso pela quantidade de número de pares vendidos até o momento (LUPETTI, 2000). A linguagem visual apresenta um jovem rapaz com expressão de reconhecimento da marca; o produto em evidência, ocupando a maior parte do anúncio ao lado de uma pena, utilizando a metáfora visual como recurso de figura de estilo linguística, designada pelo uso da imagem de uma pena, baseado numa relação de semelhança demonstrando a leveza do sapato. O nome da marca em assinatura manuscrita cria uma relação pessoal entre um produto «manufacturado» e o observador. 
Figura 55: Anúncio de Revista 2004 - Linha Quest Hidra-Yoga

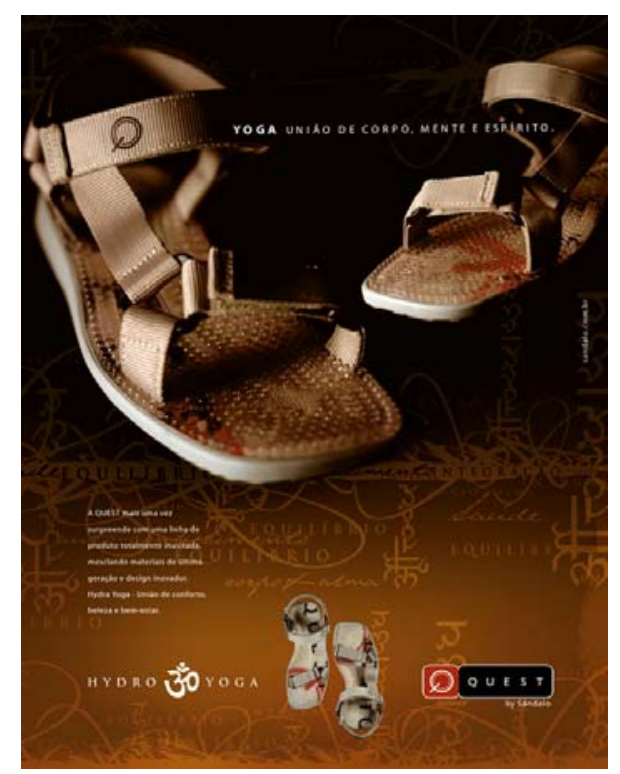

Fonte: Arquivo Depto. de Marketing dos Calçados Sândalo.

O anúncio apresenta como linguagem verbal: título - Yoga união de corpo, mente e espírito (o título projeta o leitor ao conceito de yoga que consiste no sentido de união, trabalho e aplicação. Ou seja, é o meio e o fim ao mesmo tempo. A tradução mais universalmente aceita é união porque a finalidade do Yoga é produzir no ser humano uma grande alteração na percepção ordinária da realidade, acarretando uma tomada de consciência daquilo que na realidade já é); texto - A Quest mais uma vez surpreende com uma linha de produto totalmente inusitada, mesclando materiais de última geração e design inovador. Hydra Yoga - união de conforto, beleza e bemestar. Assinatura: Hydra yoga. Quest by Sândalo. A linguagem visual apresenta o produto em evidência sobreposto em textura, cores, grafismos e ilustrações que projeta a mente do receptor diretamente aos princípios do Yoga potencializando as energias do receptor para uma vida mais plena.

A linha de comunicação utilizada nos anos 2005 e 2006 divulgam a marca Sândalo em todo o Brasil através de uma estratégia de marketing que conceitua a empresa cada vez mais, como fabricante de calçados modernos, indicados para ocasiões de cotidiano, de trabalho, lazer e noite. A campanha, desenvolvida segundo Lipovetsky (1989), as peças quer menos convencer do 
que fazer sorrir, surpreender, divertir; e esse fator está a serviço do esforço de se conquistar a adesão do que é anunciado por meio da emoção.

Ao invés da coerção minuciosa, a comunicação; no lugar a rigidez regulamentar, a sedução; no lugar do adestramento mecânico, o divertimento lúdico (CARRASCOZA, 2004, p. 91).

O produto passa a ser um elemento inserido na história e o convite à ação de compra é feito de forma indireta ou sugerida. Assim o anunciante Sândalo constrói a mensagem, apresentando as linhas de calçados e as formas de utilização, declarando os seus benefícios e diferenciais competitivos. O posicionamento busca a identificação do receptor da mensagem se projetando na utilização cotidiana do produto (SANDMAN, 2001).

Os anúncios adotam, assim, o formato dionisíaco, utilizando discursos fechados, detendo os receptores na mensagem nos pontos que mais determinam seu poder persuasivo.

A ilustração ou fotografia é muitas vezes escolhida pela repercussão afetiva que pode ter, por essa razão são incluídas nos anúncios onde a emoção domina a mensagem (Idem, p. 124).

Figura 56: Outdoor $N^{\circ} 1-2^{\circ}$ Semestre de 2005

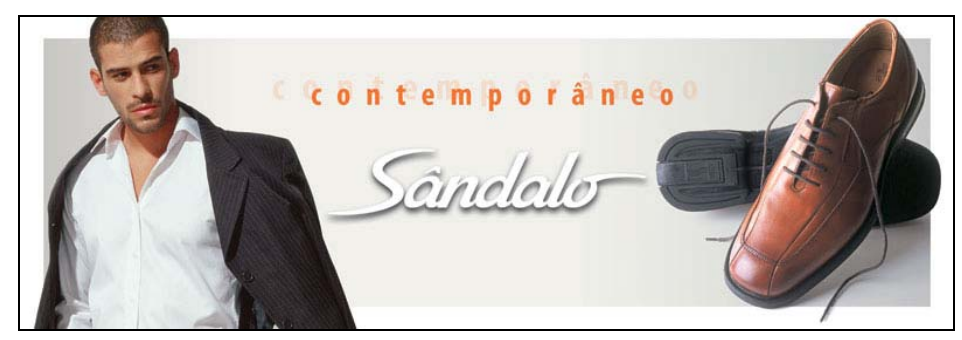

Fonte: Arquivo Depto. de Marketing dos Calçados Sândalo.

Figura 57: Outdoor No 2 - 20 Semestre de 2005.

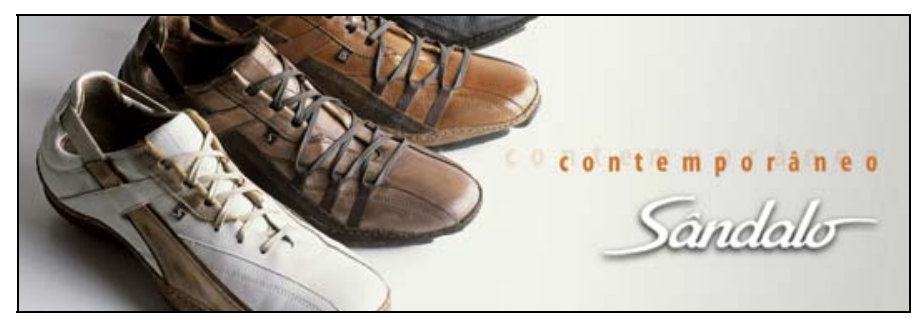

Fonte: Arquivo Depto. de Marketing dos Calçados Sândalo. 
Figura 58: Anúncio de Revista № 1 - 2ºmestre de 2005.

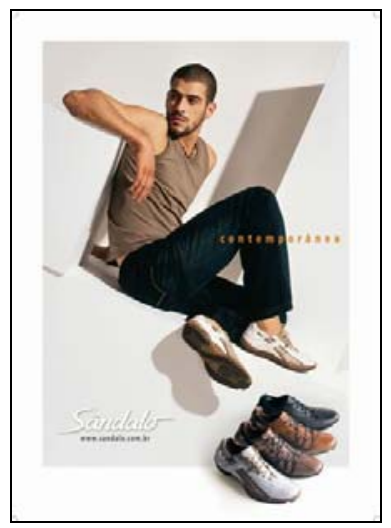

Fonte: Arquivo Depto. de Marketing dos Calçados Sândalo.

A linguagem visual apresenta como referência a modernidade, transposta nas peças pelos elementos: o homem utilizado como modelo, seu vestuário, expressão; os produtos expostos com atributos evidenciados. A direção de arte das peças contribui para a construção de um cenário que transpira à modernidade; evidenciada pela linguagem verbal intitulada como contemporâneo seguido pelo slogan, assinatura da marca e endereço eletrônico.

Todo discurso traz a cena o modo simbólico, qualquer dito é construído segundo a isotopia do não dito. É a heresia contemporânea da desconstrução que age como se uma divindade ou um inconsciente maligno nos fizesse falar somente e sempre segundo um sentido segundo, e como se tudo aquilo que dizemos fosse inessencial, pois a essencialidade do nosso discurso está alhures, no simbólico, que com freqüência ignoramos. Assim, a gema simbólica, que devia fulgurar no escuro e ofuscar-nos de improviso tornou-se uma serpentina de néon a invadir o tecido de cada discurso (ECO, 2003, p. 146-7). 
Figura 59: Anúncio de Revista Couro Moda No 1 - 20 Semestre de 2005.

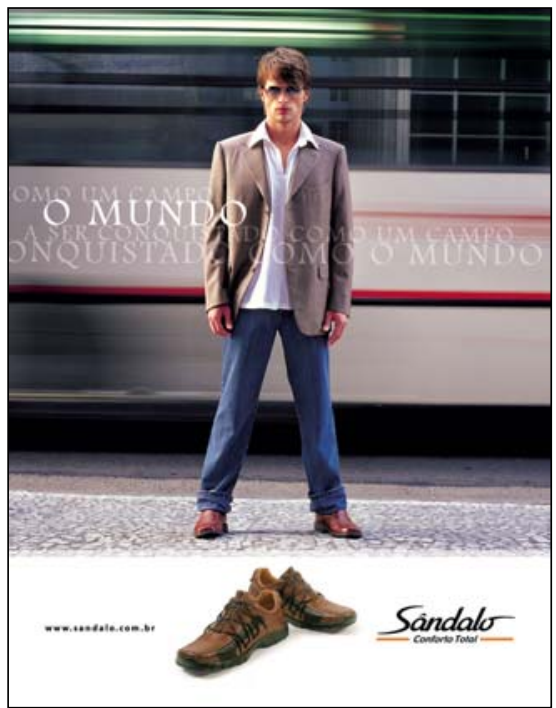

Fonte: Arquivo Depto. de Marketing dos Calçados Sândalo.

A figura 59 apresenta a linguagem verbal: Texto: Como um campo um mundo a ser conquistado - Endereço eletrônico: www.sandalo.com.br ; Assinatura: Sândalo. Slogan: conforto total. A argumentação do anúncio segue a linha da modernidade reafirmando o posicionamento do anunciante, destacando como atributo do produto o design avançado e a marca reconhecida (LUPETTI, 2000). A linguagem visual reforça o conceito de contemporaneidade pela ambientação do anúncio em uma localidade com conotação urbana e pelo perfil do modelo fotografado. 
Figura 60: Fotos do Catálogo e site Coleção 2005/2006
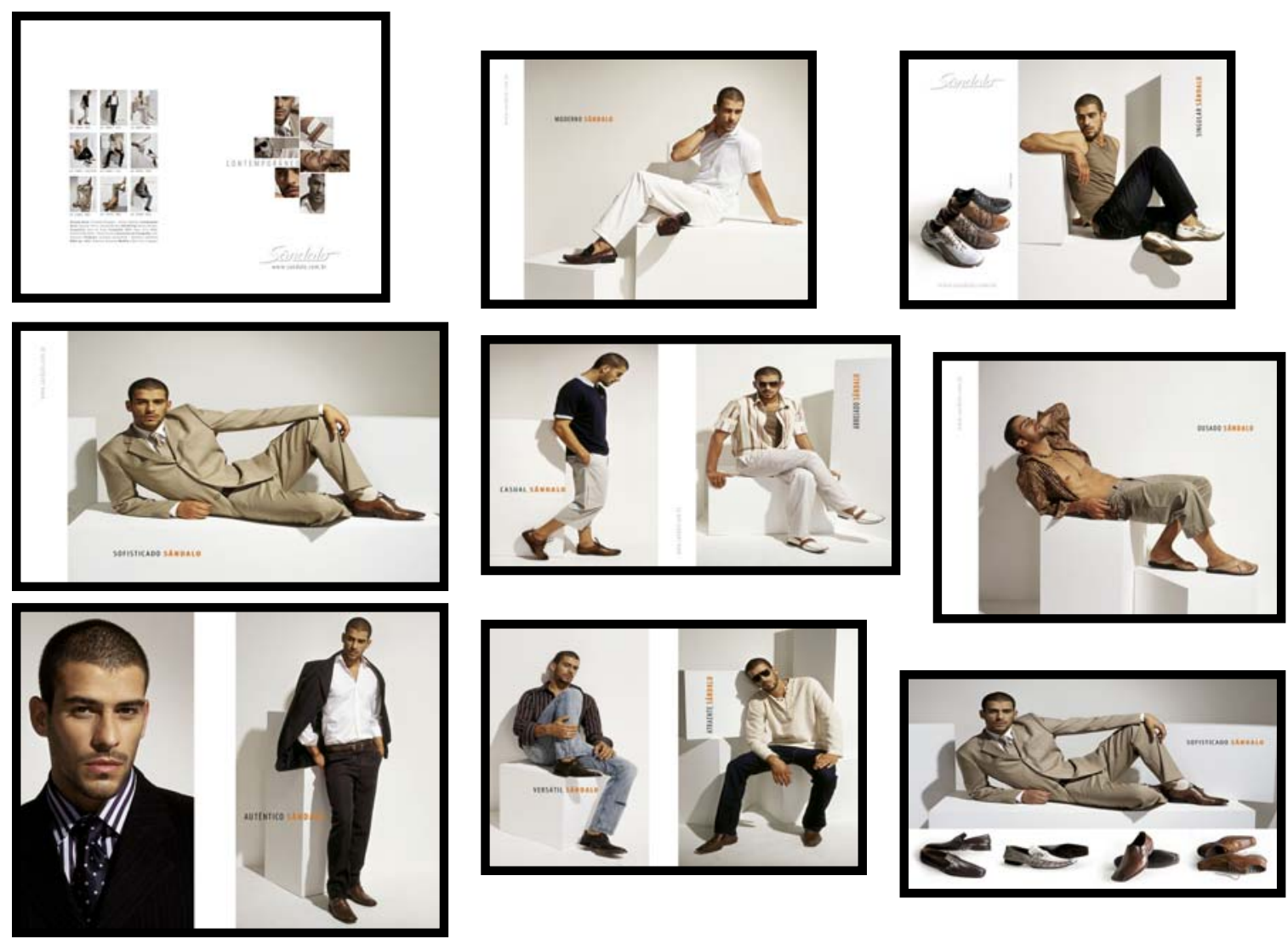

Fonte: Arquivo Depto. de Marketing dos Calçados Sândalo.

A cultura é formada por um conjunto de narrativas compartilhadas por um grupo, por meio das quais se instaura uma identidade coletiva. $O$ ato de narrar, de criar uma temporalidade coletiva tornou-se assim a base para a vida social e a confirmação e validade da nossa vida subjetiva (COSTA, 2000, p. 44.)

No mercado da moda, informação é urgência. Cria-se moda para calçar e vestir como se criam palavras e imagens para falar dela, e o que se diz, se escreve ou se mostra é tão importante quanto os produtos desenvolvidos. São palavras e imagens que, via publicidade, apresentam o produto ao consumidor.

As peças publicitárias compartilham com o produto Sândalo três qualidades: a fotografia é magnífica, usa o preto e branco e enriquece-o com o bege. O layout é clean e moderno. Com a beleza da linguagem visual, mitificam a eterna juventude. A construção das imagens transforma a sugestão dos produtos em referência de contemporaneidade (WAJNMAN; ALMEIDA, 2002). 


\subsection{PESQUISA QUALITATIVA: FOCUS GROUP}

A pesquisa qualitativa através de discussões nos grupos de foco (ou Focus Group) tem o propósito de descobrir o que o consumidor tem em mente, quais são as suas perspectivas, as suas preocupações. O uso do Focus Group tem o objetivo de apresentar as experiências em relação a uma idéia, um produto, serviço ou um evento. A discussão propiciada pelas reuniões é efetiva em fornecer informações sobre o que as pessoas pensam, sentem ou, sobre a forma como agem.

\subsubsection{Descrição}

A coleta de dados foi realizada a partir da constituição de dois grupos de discussões conforme descrito na Metodologia.

Durante a introdução, o moderador fez uma breve apresentação dos tópicos de discussão e colocou algumas regras básicas, como: somente uma pessoa fala por vez, não deve existir conversa lateral, todos devem ser encorajados a falar, etc. O grupo foi comunicado que a sessão foi filmada. A discussão teve início com a auto-apresentação de cada participante, o que serviu como quebra-gelo. A etapa seguinte foi a discussão propriamente dita. 0 moderador apresentou o primeiro tópico, que foi seguido por discussão nãoestruturada até a introdução do segundo tópico, e assim sucessivamente; a entrevista de Focus Group incluiu doze questões classificadas em: (uma) questão aberta - a primeira rodada de perguntas da sessão foi feita a todos, de forma a permitir uma resposta rápida (10 a 20 segundos), e permitiu identificar as características que os participantes têm em comum; (uma) questão introdutória - introduziu o tópico geral da discussão e forneceu aos participantes oportunidades para refletir sobre experiências anteriores; (quatro) questões de transição - essas questões moveram a conversação para as questões-chave que nortearam o estudo; (cinco) questões-chave direcionaram o estudo. São as que necessitaram uma maior atenção e análise; (uma) questão-resumo - o moderador realizou um resumo, em dois ou três minutos, das questões-chave e partir daí aguardou o surgimento idéias que emergiram da discussão. 
A pesquisa foi realizada no dia 27 de junho de 2006 envolvendo dois grupos de onze pessoas compostos por: jovens de 18 a 24 anos, homens e mulheres, universitários e/ou profissionais liberais, que consomem e também os que não consomem marcas (grifes) de calçados, escolhidos aleatoriamente por meio de contato pessoal em Instituições de Ensino Superior públicas e privadas. Os participantes foram recrutados observando as similaridades e os contrastes existentes entre elas.

As discussões fluíram de maneira natural e, sobretudo organizada. Cada membro do grupo manifestou-se no seu momento, sem que nenhum deles tentasse a imposição de suas idéias. Embora os grupos fossem homogêneos (todos universitários, com idades semelhantes) as diferenças individuais sempre aparecem nesses momentos e alguns membros dos grupos falaram mais que outros. As discussões duraram em média 1 hora e 45 minutos e foram gravadas em fitas de vídeo para facilitar a análise dos dados. O conteúdo das fitas foi transcrito e complementado pelas anotações da pesquisadora.

\subsubsection{Resultados}

Os resultados apresentados a seguir foram literalmente transcritos levando-se em consideração o fato de só emergirem na pesquisa a partir do roteiro de pesquisa e serem resultados enfatizados pelos participantes. 


\subsubsection{Primeiro Grupo}

1)

Estar na Moda é seguir uma tendência. É ter no guarda-roupa as roupas que aparecem na TV, ou seja, os que os artistas usam. Depois que os artistas da TV aparecem no ar com as roupas e acessórios, as lojas se interessam em comprar. Aí as pessoas fazem a ligação do que apareceu na TV e do que tem nas lojas e começam a querer usar também, os mesmos produtos com 0 padrão e a tendência. Um exemplo é a bota de salto anabela neste inverno, é a moda, todos querem ter, é a peça básica da coleção, quem não tem "tá por fora".

Acredito que a Moda é usar o visual que está na moda, respeitando o que fica bem pra cada um e o que a pessoa realmente gosta. Não é correto usar algo que não goste só porque está na moda.

Estar na Moda é sair do padrão, ser diferente, criar o seu próprio visual. Um exemplo são as modelos ou celebridades como cantores nacionais e internacionais, que vão além do que é tradicional e do que se vê e se usa nas ruas, como cabelos com cores e cortes exóticos, roupas customizadas etc.

Estar na Moda é criar a sua própria, com a sua cara, a sua personalidade e o seu próprio estilo.

Seguir a Moda é interpretar as tendências que são informações de formas, estilos, modelagens, tipos de tecidos e adequar tudo isso ao seu próprio estilo e ao seu guarda-roupa, de forma que você fique com um visual criativo, bonito e moderno, sem parecer um "ET de tão diferente".

Estar na moda é comprar e usar os lançamentos das marcas existentes no mercado. As marcas lançam a cada estação, roupas, sapatos e outros 
acessórios diferentes. Para estar sempre bem vestido, basta eleger uma marca que combina com a sua personalidade e estilo de vida e comprar o que ela vende.

2)

A definição de Moda para calçados existe muito mais para o feminino que apresenta a cada estação novidades, produtos diferentes, inovadores e variados. Para os modelos masculinos as ofertas são mais tradicionais, seguem um padrão. Por exemplo, está usando sapato de bico quadrado faz um tempão, ficam anos usando a mesma coisa. Para mulher é diferente, no verão usa um tipo de salto e no inverno muda completamente. O mesmo para as cores, no feminino é ousado, para o masculino os modelos são tradicionais e básicos.

Para o masculino demora sair um estilo da moda, como por exemplo, o sapatenis, está usando já faz algum tempo, demora sair da moda.

A moda é engraçada, agora a gente acha linda, depois quando passa um tempo a gente acha horrível, cafona, como foto antiga.

A moda feminina muda muito rápido. A masculina demora sair um produto de linha.

Usar um sapato masculino da moda, é usar um sapato mais básico, combina com tudo e pode ser usado em qualquer ocasião. O sapato para as mulheres tem outras necessidades, elas precisam de um modelo para combinar com cada roupa e ocasião.

Moda em calçados depende de como a marca é divulgada. As Havaianas eram consideradas como chinelo de pobre, hoje é produto da moda, é fashion, tem loja própria, vende no mundo inteiro, e tem modelos caros. 
3)

As marcas lançam os calçados seguindo as tendências internacionais da moda. A marca é a moda em si, dita a moda.

A grife dá a referência de moda. Se a marca "X" lançou na coleção é porque está na moda. Ninguém questiona.

A Marca está relacionada ao prestígio e ao status que a utilização da mesma proporciona.

Não acredito que para estar na moda precise usar um sapato de marca ou de grife. Após o lançamento das marcas famosas, os fabricantes do mundo inteiro copiam e colocam as suas marcas próprias nos produtos. Então você pode usar, por exemplo, um sapato do Free Way, copiado de uma Prada. A marca Carmen Steffens copia uma tendência de marcas famosas mundialmente, e outras fábricas menores que ela, copiam a coleção que ela lança e assim sucessivamente. O visual vai estar perfeito, então não precisa necessariamente ser de marca famosa.

A moda está mais para o visual, a pessoa usa o calçado de marca para mostrar que tem poder usar a grife dá prestígio para a pessoa e a insere em um grupo que valoriza e reconhece a marca.

Usar sapato de marca dá para a pessoa a segurança de estar com um produto de ponta em tecnologia, em design, em qualidade etc.

4)

Os elementos que caracterizam uma marca de calçado são: qualidade; a ousadia (ela pode exagerar um pouco para se diferenciar, é aceita e reconhecida); diversidade de produtos; estilo; design; tradição da marca (o básico e chique como a Samello); o acabamento; a qualidade; a durabilidade.

As características das marcas vão de encontro ao estilo de cada público-alvo.

5)

As pessoas usam a marca para obtenção de prestígio e reconhecimento dentro do seu grupo social ou de referência. São capazes de usar até um produto que não justifica o seu preço, como a sandália Melissa com strass que custa 500 reais, as garotas ganham o prestígio porque quem vê-las usando o produto o 
reconhece e sabe que custa caro, então vai receber o prestigio por isso, tem o poder, pode pagar esse preço porque tem muito dinheiro.

Usa marca quem tem necessidade de ser aceito em um grupo que a pessoa se projeta, com a marca a pessoa vai ter status, vai se sentir importante e aceita pelo grupo de referência.

A utilização de marca tem esse significado de prestígio, principalmente na adolescência que o jovem ainda não tem sua personalidade totalmente formada e precisa de um apoio. Então para ser aceito, se auto-afirmar, ficar seguro e ser reconhecido quanto à maneira de se vestir ele se apóia em uma marca que se identifica com o seu estilo de vida.

As pessoas em geral usam grife para se auto-afirmar e serem reconhecidos. Querem passar algo que não são realmente. Quem tem muito dinheiro não se preocupa em usar tantas marcas e mostrar isso. Percebe-se que quem realmente dá mais valor às grifes, compra em cinco vezes, por exemplo.

Nos adultos esse comportamento não aparece apenas em roupas e acessórios, mas também em bens mais caros, como carros, casas, viagens e restaurantes.

Calçado de marca significa qualidade, status.

Quando fala de marca vêm na cabeça marcas de sapatos famosas no mundo, como: Nike, Adidas, Prada etc e não marcas de calçados de Franca, mesmo que eu não tenha produtos dessas marcas.

A marca famosa lança o modelo e as outras copiam. Hoje em dia as cópias estão muito próximas do original. A cópia é perfeita e por um preço muito bom que a gente pode pagar. É igualzinho, só que é cópia. Tem gente que não liga e usa assim mesmo. Tem gente que paga caro e não usa nenhum produto falsificado ou similar.

Usar marca significa estar na frente das tendências.

Existem pessoas que quando estão usando marca sentem-se bem, faz bem para o ego, sente-se bonita, poderosa, em cima das tendências. 
6)

Os papéis assumidos pelas marcas de moda expressam um modelo de comportamento, um conceito, um estilo e personalidade diferenciada, uma forma de irreverência e ousadia como os sentimentos dos jovens que não conseguem ser exteriorizados.

A Influência na vida de um jovem aparece na medida em que incentiva e instiga o consumo em parcelas da população que nem sempre tem poder aquisitivo para comprar os produtos. O jovem faz de tudo para comprar os produtos da moda para serem aceitos. Muitos jovens que não têm dinheiro pra comprar o produto da marca da moda, revoltam-se, fazem de tudo pra ter, vide o exemplo de garotos trombadinhas que roubam tênis, bonés, bicicletas etc. Um exemplo são os Office boys, que só usam tênis caros e camisetas de marca, eles não ganham pra isso, mas fazem diversas prestações pra poder ter.

O jovem vive competindo no seu grupo, cada um quer ter o produto mais novo e mais avançado que o outro. Querem ter as inovações tecnológicas antes dos seus amigos, como lançamentos de telefones celulares.

Para o jovem que não tem dinheiro, complicado, os pais não podem dar as grifes e o jovem sente-se inferiorizado por não usá-las.

7)

A relação existente entre os anúncios projetados nos anúncios e os jovens:

As marcas segmentam o seu público e para atraí-lo, colocam nos anúncios informações que esse público se identifica. Essas informações vão desde as cores usadas, o conceito da marca passado através da expressão do garoto ou garota propaganda, e o estilo do produto, por exemplo, calçado para aventura, esporte, social, lazer etc e a situação escolhida para mostrar esse produto.

O jovem se identifica com essas informações dos anúncios e se deixa influenciar por ele. Por exemplo: quero ficar bonito igual o Gianecchini. Eu me espelho na propaganda acho bonito e também quero. Se ele usa Democrata eu também vou usar, pelo menos o nosso sapato é igual. 
O jovem se projeta no artista ou modelo que divulga a marca. É necessário que haja uma identificação com o produto e com as pessoas que usam esse produto.

Não acho que é só o artista ou o modelo que influencia na escolha do produto. Alguns anúncios de propaganda chamam a atenção pelos detalhes. Em propaganda de sapato, é sempre igual, então precisa de um cara como o Gianecchini para chamar a atenção.

Geralmente os anúncios de sapatenis, mostram modelo jovem e sarado, direcionando a comunicação ao jovem. Outros anúncios com ambiente de executivo, estão direcionados para os adultos que trabalham com roupas sociais.

Esses anúncios atingem o jovem pela identificação que o mesmo tem com o artista, que empresta a sua imagem para o produto. Também tem os anúncios sem artistas como a linha Urban da Carmen Steffens, que mostra uma ambientação urbana que o jovem se identifica e o produto em destaque.

Todos os anúncios de revistas e outdoors de sapatos são muito iguais. Não há diferenciação ou criatividade. É constituído de um lado um modelo e do outro o produto em tamanho grande, bem visível, sem texto nenhum, só com a marca. Apenas a fotografia. Quando a fotografia é bonita, chama a atenção, mas não sai da mesmice.

8)

A propaganda está presente em tudo, onde você está tem algo sendo comunicado. O tempo inteiro. Causa influencia no jovem ver outro jovem usando. Como as roupas da Colcci, você paga $\mathrm{R} \$ 300,00$ pra fazer propaganda da Coca Cola, ou para usar uma calça igual a que a Gisele B. apareceu na revista. Os anúncios mostram a forma de usar e compor a roupa, o sapato, o estilo. A propaganda divulga o conceito, a cara da moda, o estilo tipo mocinha da Malhação, de uma banda da moda, coloca homens e mulheres lindos, que a 
gente olha e fala, quero ser igual então vou comprar o produto. O jovem se projeta no modelo de beleza estabelecido pela mídia.

9)

O papel social da propaganda de moda de calçados padroniza o público, todos usam a mesma coisa. Querem usar o sapato da moda pra ficar diferente do total, mas iguais aos seus amigos mais próximos ou ao grupo que deseja participar.

Dependendo da ocasião, existe a indicação da moda para o produto que se deve usar. Por exemplo: no trabalho, um advogado usa sapato social porque deve se vestir com um terno, fora do local de trabalho ele vai usar um sapato mais esportivo, pra usar com jeans, por exemplo, com bermuda, usa outro modelo, um sapatenis e com shorts um chinelo; para cada ocasião tem uma indicação de produto. A propaganda ensina como usar o produto e com que roupa fica legal. A propaganda mostra o produto "da hora" e como usá-lo. Cria o desejo no público de ter aquele produto, porque sempre tem uma novidade, um tênis sempre tem uma cor nova ou algo que diferencie pra que as pessoas queiram substituir o que já tem em casa. Só pra ter algo novo. A propaganda tem uma indicação pra cada público, ela muda pra atingir as pessoas que ela quer. A propaganda se comunica com cada público, separando-os em tribos. A propaganda para jovens é diferente para chamar a atenção deles.

10)

O jovem gosta de ídolos usando os produtos e a propaganda aproveita isso. 0 jovem se identifica com quem está divulgando o produto na propaganda, e vai usar ou não se quer ser igual a quem está anunciando. O que os jogadores da seleção ou atletas famosos usam, todos acreditam que seja o melhor, por exemplo: a chuteira do Ronaldinho deve ser a melhor senão ele não usaria. A Xuxa usa o creme "tal" então é bom porque ela tem a pele linda. A Susana Vieira faz propaganda de produto de limpeza e as donas de casa se identificam com ela pelo personagem que ela fez na novela tempos atrás. O testemunhal faz com que os jovens acreditem, agrega valor ao produto, empresta a imagem do modelo, ou artista ao produto e o público se identifica e quer ser igual. A 
Hebe fazendo propaganda de lingerie para jovem não vai vender, ninguém vai querer usar a lingerie que a Hebe usa!

A TV influencia mais na moda do que os anúncios de revista. Por exemplo, todas as mulheres querem o vestido que a Vitória usa na novela Belíssima, tem uma loja em São Paulo, que produz a noite o que a artista usa na novela, no outro dia de manhã tem fila pra comprar o "modelito". Nas discotecas sempre tem um monte de garotas usando gravatas, influenciadas pela série Rebeldes. Os artistas lançam moda na novela, filmes e séries, e o que eles usam "vira moda", todos querem comprar.

Os detalhes mais importantes e valorizados em uma marca são: a qualidade, o conforto, a durabilidade, no caso de sapatos masculinos. No caso de sapatos femininos, o que realmente importa é a beleza, o design, a tecnologia. Não importa se dura ou não, se é confortável ou não a mulher quer ficar bonita, sexy, e reconhecida como fashion, moderna e que está na moda.

12)

Em síntese: a instalibidade constitui a natureza da moda. A diferença da moda para os homens e as mulheres. Os elementos que caracterizam a moda são a ousadia, a garantia e a qualidade. A marca define um padrão. Os jovens aderem a esse padrão para se diferenciar e para não se sentir diferentes do grupo que deseja a sua aceitação e a inclusão. O padrão gera status. O papel social influencia no comportamento do jovem, fazendo com que ele demonstre ser o que não é só para obter a admiração e aceitação social. Usar uma grife proporciona ao jovem conforto, melhora o seu ego e sua auto-estima. As propagandas de sapato são muito iguais sempre. O que mais influencia nos anúncios são os artistas em primeiro lugar e em segundo cantores e cantoras. Lança moda e influencia o jovem, antes mesmo da revista ou outra mídia qualquer, aparecer com os artistas das novelas e séries. 


\subsubsection{Segundo Grupo}

1)

Chama a atenção em uma propaganda: se for na TV, a música; quando estou andando de carro eu presto atenção nas fotografias dos outdoors.

Chama a minha atenção a música - em propaganda de rádio e tv.

O humor me prende a atenção, adoro me divertir com a propaganda.

O cenário chama a atenção e a música fica na cabeça.

O texto se for inteligente também chama a atenção.

Chama à atenção a adequação da linguagem e da fala com o público do produto anunciado. A beleza da cena com gente bonita e diferente.

Eu valorizo algo que não passa despercebido, que seja fora do comum e criativo. Sacadas como anúncios de cabeça pra baixo em uma revista, sai do comum e você para pra olhar, poxa o que é isso?

Chama à atenção a cor que causa o impacto inicial. Anúncio conceitual que nem tem texto, mas comunica muito pela expressão do rosto e do corpo.

Muitas coisas chamam a atenção, depende da construção do anúncio, mas tem que ser atrativa, diferente, bem bolado. Eu gosto do Humor sutil não o escrachado. A cara do modelo sempre me chama a atenção.

2)

Cada um tem uma concepção de moda. Cada pessoa monta um visual. O que fica legal pra um, pra outro fica ridículo. 
Eu vejo revista de moda e o que está exposto não aparece nas ruas, são muito diferentes, os desfiles mostram as tendências, mas não vejo isso na rua. Hoje a moda está muito diversificada. Antes, quando usava uma coisa, todo mundo era igual, por exemplo, anos 50, todas as mulheres eram iguais e os homens também. Hoje tem várias coisas e estilos na moda.

Cada um tem seu estilo, mas as pessoas não param pra pensar o que combina com o corpo, não seguem um estilo próprio. Moda é informação, usar o que fica bem pra pessoa.

Eu sou contra modismo, não vou usar o que está na moda porque todo mundo está usando. Tem que ter senso crítico tem que cair bem e gostar e não usar apenas porque está na moda

Os adolescentes se vestem de forma iguais, bem padronizados. Aí fico pensando: será que todos têm dinheiro pra comprar as mesmas grifes? Claro que não e tanto os jovens como os pais sofrem com isso. Parece que agora é mais do que na minha época, existe uma uniformidade muito grande.

Moda é atitude. Moda é bom pra enriquecer o produtor.

Moda é grife, pode ser brega, mas se tem etiqueta é chique e todo mundo acha importante e bonito e desfila a etiqueta bem grande.

Está ligada à personalidade e conhecimento próprio, vai usar o que combina com ela e vai ser mais difícil ser persuadida. Sempre segue uma tendência, mas não padroniza, tem que ter estilo próprio. Por isso quem tem mais personalidade dita a moda. Essas pessoas são mais autênticas, tem voz ativa e fazem com que as pessoas se vistam igual a elas, influenciando na forma de composição do visual.

Roupas que são mais diferentes eu tenho vergonha de usar na minha cidade que é pequena, mas se eu for pra são Paulo eu uso coisas mais diferentes sem 
problema porque ninguém me conhece e as pessoas lá são mais ousadas. O que as celebridades usam vira moda, todo mundo quer usar.

3)

O que conta é a grife. Eu já ouvi meninas dizerem assim: "Homem você analisa pelo sapato" por ser algo mais caro, e não se compra constantemente, você escolhe mais qualidade e procura marcas que dão esse aval de qualidade e claro, de tendência de moda. Calçado se gasta mais, não se vê muito o preço, porque não compra quantidade. Então tem de ser bom para durar bastante. $\mathrm{Na}$ minha casa, quando precisamos, vamos às lojas de fábricas e compramos por um preço ótimo, produtos de marca. Geralmente é produto que a entrega foi cancelada ou que não passaram pelo controle de qualidade, já comprei tênis Keds por 20,00 enquanto que na loja era 180,00 .

Eu não vejo marca em sapato, nem fico sabendo marca. Agora tênis é diferente, aí eu vejo a marca, a tecnologia usada.

Mulheres consomem muito mais, porque usam tênis, sandália, bota, cada um para uma ocasião.

Sapatos duram cinco anos no mínimo, então eu só vou pensar nisso quando o meu estiver bem velho. Mesmo porque, jovem usa muito pouco sapato. Usa mais é o tênis. Eu também sou assim.

Em minha opinião, o sapato dura, mas é no armário, porque sai da moda na próxima coleção. E ai precisa comprar outro para ficarmos "em cima". Todas as mulheres querem ter o que está usando naquela coleção.

Eu presto atenção no conforto. Carmen Steffens, por exemplo, é muito desconfortável, as mulheres compram pela beleza.

Eu não ligo para a marca de sapato. Eu vejo só o preço, quando vou comprar, escolho dois que duram 3 meses, em vez de um que dura seis meses. Eu escolho dois, um preto e um marrom e pronto, tenho por muitos anos. 
Eu tenho apenas 1 sapato, e vários tênis, não ligo a mínima. Considero sapato coisa de adulto ou homem mais velho.

Pra mulher quando vai pra balada usa rasteira ou bota e aproveita muito mais, mas a gente quer mais é ficar bonita. Mulher é sempre mais "arrumadinha". Homem muito "arrumadinho" todo mundo tira sarro, eles são sempre mais largados. Ninguém olha o sapato, mulher acha que não pode repetir. Mas homem não presta atenção nisto. Mas as pessoas esperam que a mulher esteja mais arrumada, produzida, e prestam atenção sim.

A calça jeans aparece a marca, mas o sapato não aparece. Se estiver legal, não dá pra ver de onde é, qual a marca. Tênis tem de ser bom, mas sapato eu olho é o preço. Sapato de mulher só vê o estilo. As fábricas copiam muito, então tem de todos os preços, mas no pé não dá pra ver a marca. Estar na moda não está ligado à marca e sim à tendência do momento. Tem muita cópia e alguns produtos nem dá pra perceber que não são originais. Marca para homem só se for pra tênis. Para sapato não importa muito. Para mulher depende, Melissa, por exemplo, é de plástico, mas tem marca. Agora a maioria não aparece mesmo a marca, mas dá pra ver de longe se tem qualidade e se tem bom acabamento. Então nesse item a marca é importante, porque normalmente usa matéria prima de maior qualidade. Couro ao invés de sintético faz toda a diferença em um calçado tanto feminino como no masculino. Agora se falarmos de um acessório, uma bolsa, pode até usar um sintético, mas o design é tão diferenciado que pode ser usado sem vergonha, muito pelo contrário, achando o máximo. Concluindo o raciocínio, não é que vai aparecer a etiqueta da marca, mas o visual muda pelo conjunto que a marca oferece.

4)

Os elementos que caracterizam uma marca de calçado são: diferenciação; estilo; design; preço; acabamento; material; cor; lançamento; qualidade; a publicidade; o preço; atitude. 
5)

Calçado de marca significa: conforto; status; durabilidade e qualidade.

6)

Os papéis sociais assumidos pela marca de moda são: a aceitação social, a afirmação social, o prestígio e a inclusão social.

A influência é a superficialidade nos relacionamentos. A preocupação do jovem é ter tudo da moda pra ser aceito, o tênis e roupa de grife, celular "top" de linha etc. Esta influencia é negativa porque os jovens preocupam em passar através do vestuário uma imagem que nem sempre condiz com a sua capacidade financeira. Os jovens querem chamar a atenção com um visual legal, e ficam por isso. A marca tem o papel de impactar. Usam marca com o objetivo de mostrar algo. A publicidade dá a postura para a marca, quando o jovem usa a marca ele pega emprestado a personalidade e a atitude da marca.

7)

Os anúncios de propaganda expostos apresentam: a) Democrata não tem foco para o público jovem. Os anúncios mostram sempre executivos, homens mais velhos. Sapato não combina com jovem, tênis sim. b) Homem não quer usar sapato porque não é confortável. E os anúncios mostram sapatenis direcionando os produtos. Os anúncios mostram um cara com um modelo de sapato ou sapatenis e ao lado vários modelos do sapato. Eles tentam passar o conceito através dessas imagens. Os anúncios mostram o produto com a forma de uso: aventura, esporte, lazer e mostra situações para passar a mensagem.

8)

A propaganda divulga a moda em todo o momento. Na TV, na rua nos outdoors, nas revistas, no rádio etc.

O jovem quer ser igual ao seu ídolo. A propaganda influencia o jovem ao mostrar quem está usando o produto, jogador de futebol, por exemplo. Os jovens se espelham em atletas, artistas ou modelos com padrão de beleza. 
Ator e atrizes ditam a moda, os jovens se identificam com os produtos. Antigamente existiam marcas com nomes de artistas e atletas para crianças, hoje em dia, isso também vale para jovens.

Acho que qualquer modelo, bonito, que o jovem se identifica e quer ser igual, influencia o jovem. Para sapatos os atletas e artistas influenciam os jovens, mas para roupas são os modelos que vendem o padrão de beleza estabelecido pela sociedade de consumo.

Os jovens olham nas revistas, nas vitrines e até nos vendedores a forma de usar e compor o visual, e se identificam e usam também. A novela dita a moda através do merchandising, cantores de rock. A mídia promove a moda.

9)

O papel social desempenhado pela propaganda de calçado: desperta o que a pessoa não é - ela se projeta, vai usar o sapato com algum objetivo: ficar na moda, ficar tão bonito quanto o modelo da revista, o atleta ou o artista da TV ou da música.

Sapato no masculino passa seriedade. Na mulher é elegância, feminilidade, sensualidade. A propaganda instiga as pessoas a consumir mesmo que não precisem e não possam ter aquele produto.

10)

As propagandas são muito iguais, geralmente mostram o sapato em primeiro plano, bem grande, com as versões de cores e modelos e um cara ou uma moça. Integra personalidade de sapato com o público-alvo. Diferencia na questão atitude e estilo com o conceito da marca. Atrai o público e desperta o interesse para o jovem ir ate a loja e ver de perto o sapato, desejá-lo, querer comprá-lo.

Sapato = valor agregado é a seriedade.

Em minha opinião, ver o anúncio ou não, não faz diferença. Não acrescenta nada porque é sempre igual, não chama a atenção. Eu prefiro ver e escolher 
sapato na loja. A propaganda mostra o estilo da marca, o conceito, mas não o sapato em si.

11)

São importantes em uma marca os seguintes quesitos: estilo; padrão da marca; conforto; durabilidade; garantia.

A marca (etiqueta) tem que aparecer se eu comprei, paguei caro eu quero que apareça a etiqueta.

É importante ver quem está usando, eu não vou usar uma marca que "os manos" usam, por exemplo, não quero ser igual a eles, também não vou usar um produto que virou "carne de vaca" todo mundo tem e aí eu não quero mais. O importante é o diferencial, se é de marca tem que passar algum conceito, uma personalidade que o consumidor jovem se identifique.

Resumo = Diferença entre homens e mulheres para o uso de sapatos, mulheres usam vários modelos adequando um para cada ocasião; o homem é mais básico e o modelo dura porque não sai de moda a cada estação como acontece com os modelos femininos. Valoriza em termos de elementos da propaganda a cor, a criatividade e textura ou cenários, a música, cenário, a produção. A moda é o estilo. O jovem busca se diferenciar, mas ficar igual a sua turma. Adolescente é facilmente influenciado, segue à risca a imposição de alguma marca, de um estilo, para ser aceito, para ser incluído em um grupo, a utilização da marca passa segurança para o jovem. Quando vai ficando mais velho, não liga muito, não precisa mais de tanta afirmação. Tem a personalidade formada e não encosta-se à roupinha e sapato pra provar algo. Os cantores de qualquer estilo influenciam muito na moda e tem muito prestígio junto aos jovens. Tudo é segmentado. O conceito que a propaganda passa através do ícone usado que pode ser cantor, artista ou modelo. 

T CONSIDERTEOES FNA NS 
Foram investigados os aspectos da linguagem da propaganda, e os recursos comunicacionais expressivos das relações de participação sociocultural entre o público-alvo e as marcas Democrata, Carmen Steffens e Sândalo, utilizando como referencial para a análise as teorias interdisciplinares da propaganda comercial (anúncios de revista e outdoor - mídia impressa) dos calçados da moda.

O corpus do trabalho apresenta a leitura de dois aspectos do processo de comunicação: o emissor representado pelo profissional da área de marketing, o objetivo da ação, o posicionamento; e o receptor sob o ponto de vista do consumidor, a percepção, a imagem, em relação às propostas das empresas, em se adaptarem às mudanças solicitadas pelo mercado consumidor brasileiro.

A existência da moda de calçados na publicidade e não de uma moda de calcados genericamente concebida, está relacionada com o fato de que os atores publicitários apresentam uma funcionalidade comunicacional de caráter comercial. Subjacente a esta concepção encontra-se a defesa do valor utilitário dos signos que compõem as mensagens publicitárias, como se eles estivessem submetidos a uma sintaxe de expressão publicitária que está adaptada à divulgação das mercadorias. Este utilitarismo se traduz numa estabilidade das formas expressivas do processo de comunicação publicitário cada vez mais freqüente na publicidade contemporânea. Explorando o produto com um 'pré-texto', a mensagem publicitária assume-se como o espaço de confluência intertextual de uma multiplicidade de discursos. Esta situação é importante e apresenta implicações nos signos de moda, na medida em que estes deixam de estar submetidos a uma funcionalidade comunicacional de índole estritamente comercial para traduzirem também às circunstâncias e os contextos de enunciação de discursos perpassados por outros valores. Se anteriormente a moda encontrava-se encerrada num processo de afirmação da existência do produto, atualmente, encontra-se aberta ao mundo, num processo de contextualização.

A indústria da moda faz parte da globalização de idéias. A globalização é uma internacionalização intensificada devido ao avanço 
tecnológico, onde não há mais separação entre o mercado doméstico e internacional. Mudanças nas expectativas dos clientes ou na localização geográfica transformam a natureza dos mercados exigindo novas formas de reorganização. A globalização recente se faz pelos satélites e pelos computadores ligados à Internet. É um fato natural, introduz uma era de produtos globais e supera os ciclos econômicos tradicionais. Empresas globais ignoram diferenças regionais superficiais e exploram economias de escala mediante a venda dos mesmos produtos em todos os lugares como um único mercado.

Existe o envolvimento das empresas de Moda de calçados nos programas de gestão de marca através do estudo da competição que exige conceitos, que são úteis e necessários para entender e explicar as novas relações econômicas ou sociais, e a tomada de decisões referentes à inserção de indústrias no ambiente globalizado. Cadeia de valor é um deles e significa um arranjo completo de atividades requeridas para viabilizar determinado produto, desde a concepção, passando pela produção, até a entrega ao consumidor final e sua disposição após o uso. As funções com maior potencial de agregação de valor e estão localizadas nas funções de pesquisa, engenharia e desenvolvimento de produto, no marketing e comercialização. Nesse sentido, a linguagem da propaganda agrega valor para as marcas na Indústria de Moda de calçado.

Ao afirmar que a civilização atual confere um ar de semelhança a tudo, Adorno e Horkheimer definem a padronização como o traço mais característico da indústria cultural. No entanto, a análise realizada pelos frankfurtianos leva em consideração a pluralidade dos bens culturais distribuídos no mercado; porém esta pluralidade refletiria a mera "aparência" e não a realidade social. Tal pluralidade, tão evidenciada, dá ao sujeito a sensação de que ele é reconhecido em seus aspectos singulares e não administrado na orientação de seus desejos e atitudes. Dessa forma, podemos relacionar a moda, caracterizada pela busca constante do novo, com a indústria cultural, já que esta visa exclusivamente gerar um consumo padronizado e orquestrar os gostos dos consumidores, sem, é claro, que estes percebam que estão sendo fisgados pela isca de uma ideologia interessada em sua reprodução. 
Impulsionado pelo crescimento do consumo decorrente da expansão comercial, a moda passou gradualmente a ampliar seus domínios e a atingir os diversos estratos sociais. A publicidade, juntamente com os meios de comunicação de massa, converteu-se nos mecanismos mais importantes de estratégias de venda e manipulação.

O consumidor passa a ser o objeto da indústria cultural, e esta por sua vez, extermina o que é particular, nivela a produção, sobrepõe o valor de troca ao valor de uso, padroniza as consciências, mecaniza o consumo, legitima a sociedade capitalista. O processo de massificação da sociedade e a percepção dos homens os levam a buscar nas roupas, sapatos e acessórios um meio de singularidade. No entanto, a moda não garante esta unicidade. A indústria cultural lança no mercado modelos e estilos, o que dá a sensação de poder optar e escolher, e ao mesmo tempo ela padroniza a dimensão subjetiva dos indivíduos por meio da eleição arbitrária de um padrão corporal, levá-los a uma busca constante e desenfreada por uma estética ideal.

Aos poucos a individualidade de cada um vai sendo "programada" através dessas técnicas que se tornam legítimos meios de dominação e manipulação.

A TV estimula anseios, dita comportamentos, moda e estilos de vida, buscando vender seus produtos associando-os aos artistas famosos e aos momentos de uma novela. Milhares de produtos são adquiridos pelos consumidores, que desejam poder identificar-se com o seu ídolo que divulgou determinado produto, sem que possa ter tempo de refletir sobre toda manipulação ideológica realizada pela indústria da cultura na TV.

De acordo com o estudo a percepção do consumidor em relação às campanhas de comunicação, mostra que o conceito de Moda para o jovem é seguir uma tendência. É usar o visual imposto respeitando o que fica bem pra cada um e o que a pessoa realmente gosta. É sair do padrão, ser diferente, criar o seu próprio visual. Estar na Moda é criar a sua própria moda, com a sua cara, a sua personalidade e o seu próprio estilo. É interpretar as tendências que são informações de formas, estilos, modelagens, tipos de tecidos e adequar tudo isso ao seu próprio estilo e ao seu guarda-roupa, de forma que construa um visual criativo, bonito e moderno. Estar na moda é comprar e usar os lançamentos das marcas existentes no mercado. As marcas lançam a cada 
estação, roupas, sapatos e outros acessórios diferentes. Para estar sempre bem vestido, basta eleger uma marca que combina com a sua personalidade e estilo de vida e comprar o que ela vende. Está ligada à personalidade e autoconhecimento.

Dentre os elementos que caracterizam a marca foram identificados: a qualidade; a ousadia; a diversidade de produtos; o estilo; o design; a tradição; o acabamento; a qualidade; a durabilidade; a diferenciação; o preço; o acabamento; o material; a cor; a publicidade e a atitude.

Os papéis assumidos pelas marcas de moda expressam um modelo de comportamento, um conceito, um estilo e personalidade diferenciada, uma forma de irreverência e ousadia como os sentimentos dos jovens que não conseguem ser exteriorizados. A influência da propaganda da moda junto aos jovens; consiste na padronização de "tribos" cada qual com seu estilo de vida, incentivam à superficialidade nos relacionamentos, valorizando o visual como roupas e objetos materiais e não valorizando o caráter humano do jovem relativo ao seu caráter, a informação, a inteligência etc. A preocupação do jovem é ter produtos da moda pra ser aceito, no seu grupo de referência. Esta influencia é negativa porque se preocupam em passar através do vestuário uma imagem que nem sempre condiz com a sua capacidade financeira. A publicidade dá a postura para a marca, quando o jovem usa a marca ele pega emprestado a personalidade e a atitude da marca e esse aspecto atrapalha a construção da sua personalidade e do seu verdadeiro eu. Desse modo, nesta sociedade, a moda ofereceria o novo, bem como planejaria sua própria obsolescência, impondo gostos e hábitos de vida, com a duração programada para o período de uma novela. Nos centros comerciais a moda nas vitrines são as que fazem parte dos figurinos selecionados para os atores e atrizes protagonistas das novelas; nos shoppings diversos estilos, entre eles cowboys, surfistas, skaitistas, hippies, punks, patricinhas etc. Em síntese, a indústria cultural tem como objetivo disponibilizar a diversidade de estilos de mercadorias de roupas e acessórios, e fornecer uma falsa individualidade, uma idéia de liberdade de escolha, onde os produtos pareçam ser elaborados exclusivamente para cada pessoa.

O papel social desempenhado pela propaganda de calçado desperta o que o jovem não é. O mesmo se projeta, vai usar o sapato visando 
ficar bonito igual o modelo da revista, o atleta ou o artista da TV ou da música. Inconscientemente a busca é de aceitação, de auto-afirmação e inserção social através do vestuário. Esses grupos de jovens manipulam códigos de vestuário, ao elaborar a produção diferenciada da sua própria aparência, para ser reconhecido em todos os grupos em que transita. A "rotulação" é presente na rotina dos jovens para interpretar os outros jovens do convívio, sem a preocupação de ser classificada de uma coisa e ser além dela. Os jovens trabalham a aparência basicamente para a leitura dos olhos do outro jovem que se relaciona e o processo da construção da identidade é concluído com o início da maturidade.

Os anúncios de propaganda apresentam uma mesmice, ou seja, são todos iguais. Poucas marcas apresentam uma campanha de conceito que realmente chamam a atenção do consumidor. O que mais chama a atenção nos anúncios de propaganda é quem está usando o produto. Foram citados em ordem de importância, como formadores de opinião para marcas de calçados: artistas e atletas, ídolos da música e modelos. O veículo de comunicação que mais divulga e influencia é a televisão (propaganda e merchandising), seguidos de outdoor e revista.

Em relação aos anúncios das marcas em estudo, os jovens entrevistados consideram o uso do produto sapato dirigido aos homens mais velhos e que ocupam cargos executivos. Produtos como tênis, sapatenis, papetes e chinelos são apreciados para a prática de esportes, aventura e lazer. Para mulheres, a leitura dos anúncios é que existe a necessidade de vários modelos e combinações para cada ocasião. A moda dos calçados femininos é considerada mais efêmera que a dos calçados masculinos.

A necessidade de investimento em roupas, sapatos e outros acessórios são, pois, necessidades espirituais. As roupas, sapatos e acessórios mais caros emprestam ao usuário maior respeitabilidade, apresentando uma relação entre o gasto com o vestuário e a aparência respeitável de seu usuário. A moda é uma forma de imitação que leva à disputa geral por símbolos superficiais de prestígio e status, isto é, a elite inicia uma moda e quando as classes mais baixas a imitam, num esforço de eliminar as barreiras externas de classe, ela a abandona por uma outra moda. Isso explica a rapidez com que as coleções de grifes entram e saem da moda, 
impulsionando a busca incessante do novo e por um lugar de status na estrutura social.

Não há moda sem sujeitos. Esta idéia significa que na mensagem publicitária deverá existir uma prática lingüística referente ao exercício de uma subjetividade: um conjunto de exercícios de linguagem, baseados em palavras e em imagens, que remetam para a afirmação da existência de sujeitos na mensagem ou, à personalização das entidades comerciais. Na criação das imagens de marca os produtos adquirem uma personalidade, um caráter. Todos os exercícios lingüísticos estão relacionados a um gênero específico de publicidade. A existência de uma moda específica da publicidade de marca implica que na mensagem não exista apenas uma prática lingüística significativa de uma subjetividade comercial. É essencial que também haja alguém que a protagonize: um ator que não se limite a apresentar o produto, mas que também protagonize uma atitude positiva em relação à sua existência. Ele necessariamente deverá personificar um estilo, que estará adequado ao seu estatuto no processo de comunicação publicitária. O estilo institucional remeterá para a maneira como o anunciante se apresenta ao destinatário relativamente ao produto que divulga. A evocação indireta do anunciante através de atores ao invés de remeterem para a existência do próprio anunciante, divulga os valores subjacentes à sua atuação. Estes atores irão remeter para o imaginário concreto que está relacionado com a concepção, produção, comercialização e a distribuição do produto ou do serviço. Relativamente às estrelas, os atores publicitários não são celebridades, pelo que a sua utilidade na mensagem publicitária é somente a da evocação de outros universos textuais, de outros imaginários. A moda dos atores publicitários apresenta o valor metonímico de remissão para outras narrativas, histórias, diversas produções de sentido na qual o produto apresenta o estatuto de adereço. Sendo assim, as potencialidades, no que respeita ao trabalho de moda, são infinitas: desde a evocação de um estilo rebelde, aventureiro ou infantil. Destaca-se o pormenor dos figurinos subjacentes aos atores publicitários serem muito mais ricos e criativos do que os das celebridades. Se nestas últimas, estabelece uma relação de convergência intertextual com os universos relativamente aos quais elas ganharam fama, no que respeita aos atores publicitários a situação poderá ser distinta. 


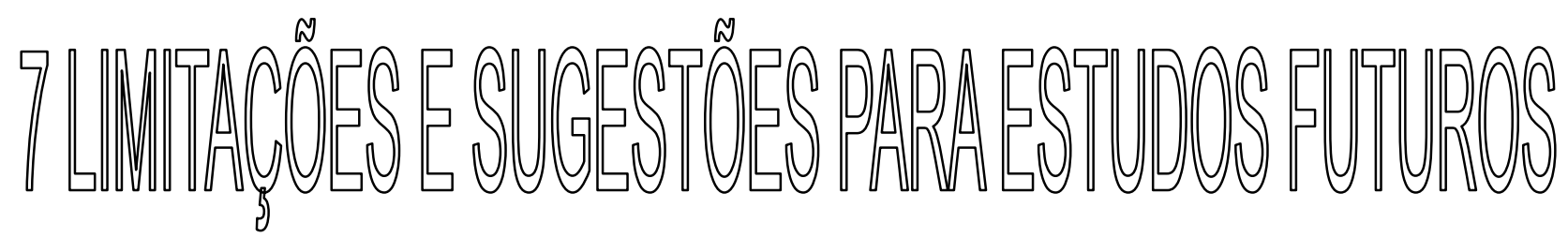


Atualmente, o mercado como um todo independente do setor de atuação tem apostado muito na implantação e manutenção de ferramentas de comunicação. As estratégias do composto de marketing vão aumentando sua participação na comunicação integrada orientada para o mercado.

Este trabalho não pretendeu criar nem tampouco desenvolver um modelo referencial completo. Esta pesquisa é restrita à visão interna das organizações que foram utilizadas como objeto de estudo.

Os resultados obtidos com as organizações estudadas não poderão ser aplicados diretamente a outras empresas ou generalizado para o mercado como um todo, devido às restrições e particularidades existentes em cada situação específica, mas podendo servir como uma contribuição inicial para o entendimento e reflexão acerca da linguagem da propaganda de moda de calçados.

De forma conclusiva, e dada a sua característica, a pesquisa em questão apresenta as seguintes limitações:

1. por se tratar de um estudo de caso múltiplo, não permite generalizações, representando apenas a realidade das empresas pesquisadas ;

2. devido ao fato de a pesquisa ser aplicada junto a universitários não necessariamente representa a visão geral do cliente em relação aos fatores estudados;

3. os fatores contemplados nesta pesquisa podem não representar ou abranger a totalidade dos elementos de valor para o cliente, mas apenas serem aqueles mais significativos, selecionados pela autora a partir da bibliografia pesquisada;

4. as limitações da autora como ser humano e eterno aprendiz em relação ao tema da pesquisa, face ao pouco que é sabido 
e à imensidão do conhecimento ainda a ser explorado nesse assunto.

A aplicação do tema desta pesquisa voltado para o mercado de organizações do setor calçadista apresenta pouca contribuição de outros autores, embora se constitua uma preocupação crescente deste mercado. Dessa forma, apresenta um campo virgem e vasto a ser explorado por novos estudos e pesquisas como:

1. estudos que explorem os conceitos e aplicabilidade das ferramentas da propaganda em outras empresas e outros segmentos de mercado;

2. estudos que comparem a visão interna da empresa com a visão real dos clientes, que através do confronto entre as mesmas pudesse contribuir para um melhor entendimento das expectativas destes em relação à percepção da linguagem da propaganda e que fatores exercem maior influência nos jovens. 


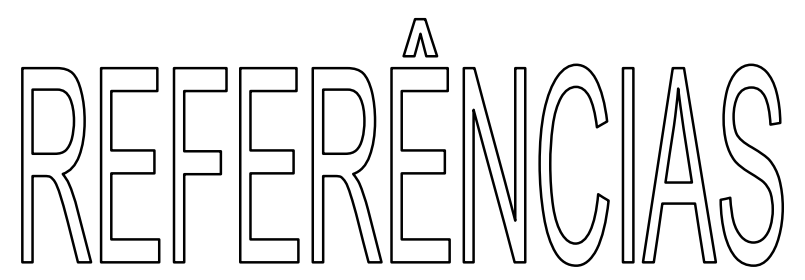


A UNESCO E A CULTURA DO BRASIL. Disponível em: http://www.unesco.org.br/areas/cultura/index_html/mostra_documento.

Capturado em: 16/10/2005.

AAKER, D. A.; KUMAR, V; DAY, G.S. Pesquisa de marketing. São Paulo: Atllas, 2001.

ALLÈRÉS, Danielle. Luxo...: estratégia-marketing. Rio de Janeiro: Ed. FGV, 2000.

ALMEIDA, Adilson José de. Moda e história. In: NIDEM - Núcleo Interdisciplinar de Estudos da Moda/UNIP. Moda, Comunicação e Cultura: um olhar acadêmico. São Paulo: Arte \& Ciência, 2002. p. 197-205.

ALTHUSSER, L. Ideologia e aparelhos ideológicos de estado. Lisboa: Presença, 1974.

ÀVILA, Aluisio Otavio Vargas A questão do conforto em calçados. Disponível em: http://www.assintecal.org.br Capturado dia 26/5/2006.

BAKHTIN, M. (Volochinov). Marxismo e filosofia da linguagem. 10. ed. São Paulo: Hucitec/Annablume, 2002.

BAKHTIN, M. Marxismo e filosofia da linguagem. São Paulo, Hucitec, 1992a.

. Estética da criação verbal. São Paulo, Martins Fontes, 1992b.

BARNARD, Malcolm. Moda e comunicação. Rio de Janeiro: Rocco, 2003.

BARROS, Antonio; DUARTE, Jorge; MARTINEZ, Regina. Comunicação: discurso, prática e tendências. São Paulo: Rideel, 2001.

BARTHES, Roland; MOSCA, Lineide do Lago Salvador. Sistema da moda. São Paulo: Nacional/EDUSP, 1979.

BAUDRILLARD, Jean. O sistema dos objetos. São Paulo: Perspectivas, 2000. . Para uma crítica da economia política dos signos. Lisboa: Edições $70,1995$.

- Significação na publicidade. Em T. Adorno e cols., Teoria da cultura de massa. 4. ed. Rio de Janeiro: Paz e Terra, 1990.

BAUMAN, Z. O mal-estar da pós-modernidade. Rio de Janeiro: Jorge Zahar, 1997.

BECKER, H. S. Uma teoria da ação coletiva. Rio de Janeiro: Zahar, 1971. 
BELTRÃO, Luiz. Subsídios para uma teoria da comunicação de massa. São Paulo: Summus, 1986.

BEMZEM. Disponível em: http://www1.uol.com.br/bemzen/sonhos.html. Capturado em: 23/4/2006.

BERNARD, Malcolm. Moda e comunicação. trad. Lúcia Olinto. Rio de Janeiro: Rocco, 2003.

BIEL, Alexandre L. Como a imagem de marca direciona a brand equity. In: $\mathrm{O}$ poder das marcas. São Paulo: Summus, 1996.

BIJÓIAS. II SALÃO DE BIJUTERIAS E JÓIAS. Revista Marie Claire, maio de 1991, p. 63.

BOONE, L. E., KURTZ D.L. Marketing contemporâneo. Rio de Janeiro: LTC, 1995. BORDENAVE, J. E. D.. Além dos meios e mensagens: introdução à comunicação como processo, tecnologia, sistemas e ciência. São Paulo: Vozes, 1977.

BRAGA, Flávio. Sociologia da moda. Revista de Cultura Vozes. Petrópolis: Vozes, ano 66, abril de 1972, nº 3. p. 9-10.

BRAGA, Gilda Maria. Semantic theories of information. Ciência da Informação, Rio de Janeiro, v.6, n.1, p.69-73, 1977.

BRANDÃO, Helena H. Nagamine. Introdução à análise do discurso. 3. ed. Campinas : Editora da Unicamp, 1994.

BUSSMANN, H. Léxico da lingüística. Stuttugard: Alfred Kröner, 1983.

CABRAL, Plínio. Propaganda: técnica da comunicação industrial e comercial. São Paulo: Atlas, 1991.

CAMARGO, Francisco C.; HOLF, Tânia. Corpo e mídia. Disponível em: http://www.facasper.com.br/pos/nucleo_pesquisa. Capturado em 30/10/2004. CAPARELLI, Sérgio. Comunicação de massa sem massa. São Paulo: Cortez, 1980.

CARRASCOZA, João Anzanello. Razão e sensibilidade no texto publicitário. São Paulo: Futura, 2004.

. Redação publicitária: estudos sobre a retórica do consumo. São

Paulo: Futura, 2003.

CARVALHO, Maria Margarida. Sociologia da moda. Revista de Cultura Vozes. Petrópolis: Vozes, ano 66, abril de 1972, nº 3. p. 8. 
CARVAlHO, Nelly. Publicidade: a linguagem da sedução. 3. ed. São Paulo: Ática, 2000.

CASTRO, Nei Leandro. Sociologia da moda. Revista de Cultura Vozes. Petrópolis: Vozes, ano 66, abril de 1972, nº 3. p. 16-18.

CENSO 2000.

Disponível

em: www.ibge.gov.br/estatistica/populacao/censo2000/universo. Acesso em: 4 de maio de 2005.

COBRA, Marcos; RIBEIRO, Áurea. Marketing magia e sedução. São Paulo: Cobra, 2000.

CONDE, Linda. A história do sapato no século $X X$. São Paulo: Kling \& Associados, 2004.

CORACINI, Maria José. Um fazer persuasivo; o discurso subjetivo da ciência. São Paulo: EDUC; Campinas: Pontes, 1991.

CORRÊA, Roberto. Planejamento de propaganda. 8. ed. São Paulo: Global, 2002.

COSTA, Cristina. Ficção, comunicação e mídias. São Paulo: Senac-SP, 2002. . A milésima segunda noite: da narrativa mítica à telenovela análise estética e sociológica. São Paulo: Annablume, 2000.

COSTA, A. R., TALARICO, E. G. Marketing promocional: descobrindo os segredos do mercado. São Paulo: Atlas, 1996.

COULON, Olga Maria A. Fonseca; PEDRO, Fábio Costa. Dos Estados nacionais à primeira guerra mundial. BH: UFMG, 1995.

D'ALESSANDRO, David F.; OWENS, Michele. Guerra de marcas: dez regras para desenvolver uma marca vitoriosa. São Paulo: Makron Books, 2002.

DORIA, Francisco Antônio. Marcuse: vida e obra. Rio de Janeiro: José Álvaro Editor S.A. / Paz e Terra, 1974.

DUCROT, Oswald. O dizer e o dito; revisão técnica da tradução Eduardo Guimarães. Campinas: Pontes, 1987.

ECO. Umberto. Sobre a literatura. Rio de Janeiro: Record, 2003.

ECO, Umberto; DANESI, A. P. Tratado geral de semiótica. São Paulo; Perspectiva, 2002.

ELA É MULTIDATA, MULTimídia, MULTinOITE, MULTIELETRÔNICA, POUPANÇA MULTIDATA ITAÚ. Jornal Folha de São Paulo, 1/5/91, p.3 -3. 
ENCARANDO

A CONCORRÊNCIA.

Disponível

em:

http://www.icarobrasil.com.br/257/blc2b_p1.htm. Capturado em 16/5/2006.

FARINA. Modesto. Psicodinâmica das cores em comunicação. 3. ed. São

Paulo: Edgard Blücher, 1987.

FEGHALI, Marta Kasznar; DWYER, Daniela. As engrenagens da moda. Rio de Janeiro: Editora Senac, 2001. p 37-57.

FOGO DE PALHA PRESENTES. Toda mãe merece. Revista Enfoque, n. 58, abril de 2006, p. 9.

FOUCAULT, M. A ordem do discurso. Tradução de Laura Fraga de Almeida Sampaio. Lisboa: Relógio D’Água Editores, 1997.

GORINI, A.P.; CORREA, A. A indústria calçadista de Franca. BNDES Relato Setorial, dez., 2000.

GRACIOSO, Francisco. As marcas são mutantes. Revista da ESPM. Março/abril, 2004.

GUARESHI, Pedrinho A. Comunicação e controle social. Petrópolis: Vozes, 2000.

GUERRA, Flávia. Dossiê universo jovem 3 MTV: mapeamento do comportamento dos brasileiros de 15 a 30 anos, das classes $A, B$ e $C$, que vivem em cidades como São Paulo, Salvador, Porto Alegre, Brasília e Rio. $O$ Estado de São Paulo. Caderno 2 - Televisão, 9 de maio de 2005.

HALL, S. (Ed.). Representation: cultural representations and signifying practices. London: Sage; The Open University, 1997.

HARVEY, D. Condição pós-moderna. São Paulo: Loyola, 1989.

HAUG, Wolfgang Fritz. Crítica da estética da mercadoria. São Paulo: Fundação Editora da UNESP, 1997.

HIRATUKA, C.; GARCIA, R. Design e Competitividade na Indústria de Calçados: Considerações a partir da aglomeração de produtores de Franca. Perspectiva Econômica, v. 36, n. 14, 2001, p. 49-64.

HOBBSBAWN, E. J. A Era das Revoluções. Rio de Janeiro: Paz e Terra, 1979. HODGE, R.; KRESS, G. Social semiotics. London: Polity Press, 1988. HOHLFELDT, Antônio; et al (orgs.). Teorias da Comunicação. Petrópolis: Vozes, 2001. 
HORKHEIMER, Max; ADORNO, Teodor W. A indústria cultural: o iluminismo como mistificação de massas. In: LIMA, Luiz Costa (org.). Teoria da cultura de massa. São Paulo: Paz e Terra, 2000.

IAHN, Roberta Cesarino. O grotesco na publicidade. Comunicare: revista de Pesquisa. Faculdade de Comunicação Social Cásper Líbero. Vol. 3. n. 1. $1^{\circ}$ semestre 2003, p. 48.

INDÚSTRIA DE CALÇADOS. Gazeta Mercantil, 14 E, 15/01/2002.

JACOBSON, R. A. Lingüística e comunicação. São Paulo: Cultrix, 1971.

JAMESON, F. Pós-modernismo: a lógica cultural do capitalismo tardio. São

Paulo: Ática, 1991.

KOTLER, Philip. Administração de marketing. 10. ed. São Paulo: Prentice Hall, 2000.

KRESS, G.; VAN LEEUWEN, T. Reading images: the grammar of visual design. London: Routledge, 1996.

LAVER, James. A roupa e a moda: uma história concisa. São Paulo: Cia das Letras, 1996.

A roupa e a moda: uma história concisa. 6. ed. Capítulo final [por] Christina Probert. trad. Glória Maria de Mello Carvalho. São Paulo: Companhia das Letras, 1989.

LEECH, G. N. English in advertising. Londres: Longman, 1966.

LINS. Daniel (org.) Cultura e subjetividade: saberes nômades. In: ROLNIK, Sueli. Toxicômanos de identidade: subjetividade em tempo de globalização. 3. ed. São Paulo: Papirus, 2002.

LIPOVETSKY, G. O império do efêmero: a moda e seu destino nas sociedades modernas. São Paulo: Cia das Letras, 1989.

. O império do efêmero. São Paulo: Cia das Letras, 1987.

LUPETTI, Marcélia. Planejamento de comunicação. 4. ed. São Paulo: Futura, 2000.

LYOTARD, J. F. A condição pós-moderna. Rio de Janeiro: José Olympio, 1979.

MAINGUENEAU, D. Novas tendências em análise do discurso. Campinas: Pontes, 1989.

MARSHALL, Gordon (Ed.) The Concise Oxford Dictionary of Sociology. Oxford: Oxford University Press, 1994. 
MARTÍN-BARBERO, Jesús. Dos meios às mediações: comunicação, cultura e hegemonia, Rio de Janeiro: EDUFRJ, 2001.

MARTINS, José. A natureza emocional da marca: como encontrar a imagem que fortalece a sua marca. São Paulo: Negócio, 1999.

MATTAR, F. N. Pesquisa de marketing. São Paulo: Atlas, 1996.

MAURO, Wolf . Teorias da comunicação. 4. ed. Lisboa: Presença, 1995.

MCCARTHY, Thomas. La teoría crítica de Jürgen Habermas. Madri: Tecnos, 1995. MCLUHAN, Mashall. Os meios de comunicação como extensões do homem. São Paulo: Cultrix, 2002.

. Moda táctil têxtil. Jornal do Brasil. Rio de Janeiro, 1/5/1969.

MERTON, Robert K. The sociology of science. Chicago: The University of Chicago Press, 1978.

MORIN, Edgar. Cultura de massas no século vinte: o espírito do tempo. Rio de Janeiro: Forense, 1969.MUNIZ SODRÉ. Reinventando a cultura: a comunicação e seus produtos. Petrópolis: Vozes, 1996.

MUSEU DO CALÇADO. História. Disponível em: http://www.museudocalçado.com.br. Capturado em: 21/1/2006.

MUSEU VIRTUAL DO CALÇADO Disponível em: http://www.museuvirtualdocalcado.com.br/ Capturado em: 5/1/2006.

NASCIMENTO, Regina Coeli. Sociologia da moda. Revista de Cultura Vozes. Petrópolis: Vozes, ano 66, abril de 1972, n³ 3. p. 14.

O PODEROSO MUNDO DOS ANÚNCIOS. [s.a.]. Disponível em http:/www.incultural.hpg.ig.com.br . Acesso em: 16/06/03.

O QUE SE LEVA DA VIDA É A VIDA QUE SE LEVA. Folha de São Paulo agora tem 3. 3224-4000. Disponível em: www.wbrasil.com.br Capturado em: $17 / 5 / 2006$.

ORLANDI, E. P. Análise de discurso: princípios e procedimentos. Campinas: Pontes, 2000.

ORTIZ, Renato. Mundialização e cultura. São Paulo: Brasiliense, 2000.

PARA CADA AMBIENTE UM ESTILO. PARA CADA ESTILO, UMA SOLUÇÃO. Revista Espaço D, n. 9, 2004, p. 150.

PERELMAN, Chaim; OLBRECHTS-TYTECA, Lucie. Tratado da argumentação: a nova retórica. 5. ed. São Paulo: Martins Fontes, 2002.

PIGNATARI, Décio. Informação, linguagem, comunicação. Cotia: Atelie, 2002. 
PIETROCOLLA, Luci Gati. O que todo cidadão precisa saber sobre sociedade de consumo. São Paulo: Global, 1987.

PINHO, José Benedito. O poder das marcas. São Paulo: Summus, vol.53, 1996.

PIRES, Maria Laura Bettencourt. Teorias da Cultura. Lisboa: Universidade Católica, 2004.

PODE TIRAR A COROA. Uma rainha nunca perde a majestade. Bohemia a primeira e melhor cerveja do brasil. Revista Veja, n07; 22/2/2006; p. 6 e 7.

PRESS RELEASE. Disponível em www.democrata.com.br. Capturado em 23/4/2006.

PYR MARCONDES E EDITORA MEIO E MENSAGEM. Marcas: uma história de amor mercadológica. São Paulo: Meio e Mensagem, 2003, p. 18.

RIBEIRO, A.H.P. Marketing de relacionamento: um processo de aprendizagem organizacional. Tese de Doutorado. São Paulo: EAESP/FGV, 1999.

RÜDIGER, Francisco. Comunicação e teoria crítica da sociedade: fundamentos da crítica à indústria cultural em Adorno. Porto Alegre: EdiPUC-RS, 2002.

SANDMAN, Antonio José. A linguagem da propaganda. São Paulo: Contexto, 2001.

- Formação de palavras no português brasileiro contemporâneo.

Curitiba: Scientia et Labor/Ícone, 1988.

SAMPAIO, Rafael. Marcas de $A$ a $Z$ : como construir e manter marcas de sucesso. Rio de Janeiro: Campus, 2002.

SANT'ANNA, Armando . Propaganda: teoria, técnica e prática. 7. ed. São Paulo: Pioneira, 1998.

SANT'ANNA, Patrícia. Desfile de imagens: um estudo sobre a linguagem visual das revistas de moda 1900-2000. Dissertação de Mestrado. Depto. de Antropologia Social do Instituto de filosofia e Ciências Humanas - Universidade Estadual de Campinas - SP, 2002.

SAUSSURE, Ferdinand de. Curso de lingüística geral. Trad. Antônio Chelin, José Paulo Paes e Izidoro Blikstein. São Paulo: Cultrix, 1995.

SE VOCÊ QUER SABER SE A UNIÃO SOVIÉTICA VAI VIRAR DESUNIÃO SOVIÉTICA, ASSINE A FOLHA. Jornal Folha de São Paulo, 3/2/90, p. C-7. 
SCHMID, Aloísio Leoni. A idéia de conforto: reflexões sobre o ambiente construído. Curitiba: Pacto Ambiental, 2005.

SCHMITT, Bernd; SIMONSON, Alex. A estética do marketing: como criar e administrar sua marca, imagem e identidade. Tradução de Lúcia Simonini. São Paulo: Nobel, 2000.

SERAGINI, Lincoln; GUARDADO, Sérgio. Habitat de marca. Revista da ESPM, Vol 10, Ano 09, Ed n² 2, 2003, p. 31.

SEVERIANO, Maria de Fátima. Narcisismo e publicidade: uma análise psicosocial dos ideais de consumo na contemporaneidade. Anablume: São Paulo, 2001.

SORDAS, Tatiana C. Sexo vende? Disponível em: http://amanha.terra.com.br. Capturado em 26/5/2006.

SOUZA, Gilda de Mello. O Espírito das roupas: a moda no século dezenove. 3. ed. Cia das Letras, São Paulo, 2005.

SÓ EXISTE UMA COISA MAIS BONITA QUE UM SUTIÃ TRIUMPH. Outro sutiã triumph. Triump, o showtiã. Revista Desfile, setembro de 1990, p. 10.

SUPERPOUPE TÃO SEGURO QUANTO A POUPANÇA E, NO FIM DO MÊS, SEU DINHEIRO GERA MUITO MAIS DINHEIRINHO. Revista Veja, n07; 22/2/2006. p. 6 e 7).

SUZIGAN, W.; FURTADO, J.; GARCIA, R.; SAMPAIO, S.. Coeficientes de Gini locacionais (GL): aplicação à indústria de calçados do estado de São Paulo. Anais do XXX Encontro Nacional de Economia, Nova Friburgo, ANPEC, dez/2002.

TORQUATO, Gaudêncio. Cultura, poder, comunicação e imagem: fundamentos da nova empresa. São Paulo: Pioneira, 1991.

UNDERHILL, Paco. Vamos às compras: a ciência do consumo. Rio de janeiro: Campus, 1999.

VARELA, Dailor. Da tropicália ao lamê. Sociologia da moda. Revista de Cultura Vozes. Petrópolis: Vozes, ano 66, abril de 1972, nº 3. p.21-26.

VATTIMO, G. O fim da modernidade: niilismo e hermenêutica na cultura pósmoderna. São Paulo: Martins Fontes, 1985.

VERÓN, Eliseo. A produção de sentido. São Paulo: Cultrix-EDUSP, 1981. 
Ideologia, estrutura e comunicação. 2. ed. São Paulo: Cultrix, 1977.

VIP EXPRESS: A GRIFFE EM TRANSPORTE DE MÓVEIS. Revista Espaço D, n. 9, 2004, p. 103-104 e 129.

WAJNMAN, Solange; ALMEIDA, Adilson José. Moda, comunicação e cultura. São Paulo: Arte \& Ciência; NIDEM; FAPESP, 2002.

YIN, Robert K. Case study research: design and methods. Sage: Applied Social Series, 1989. 
ANEXOS 

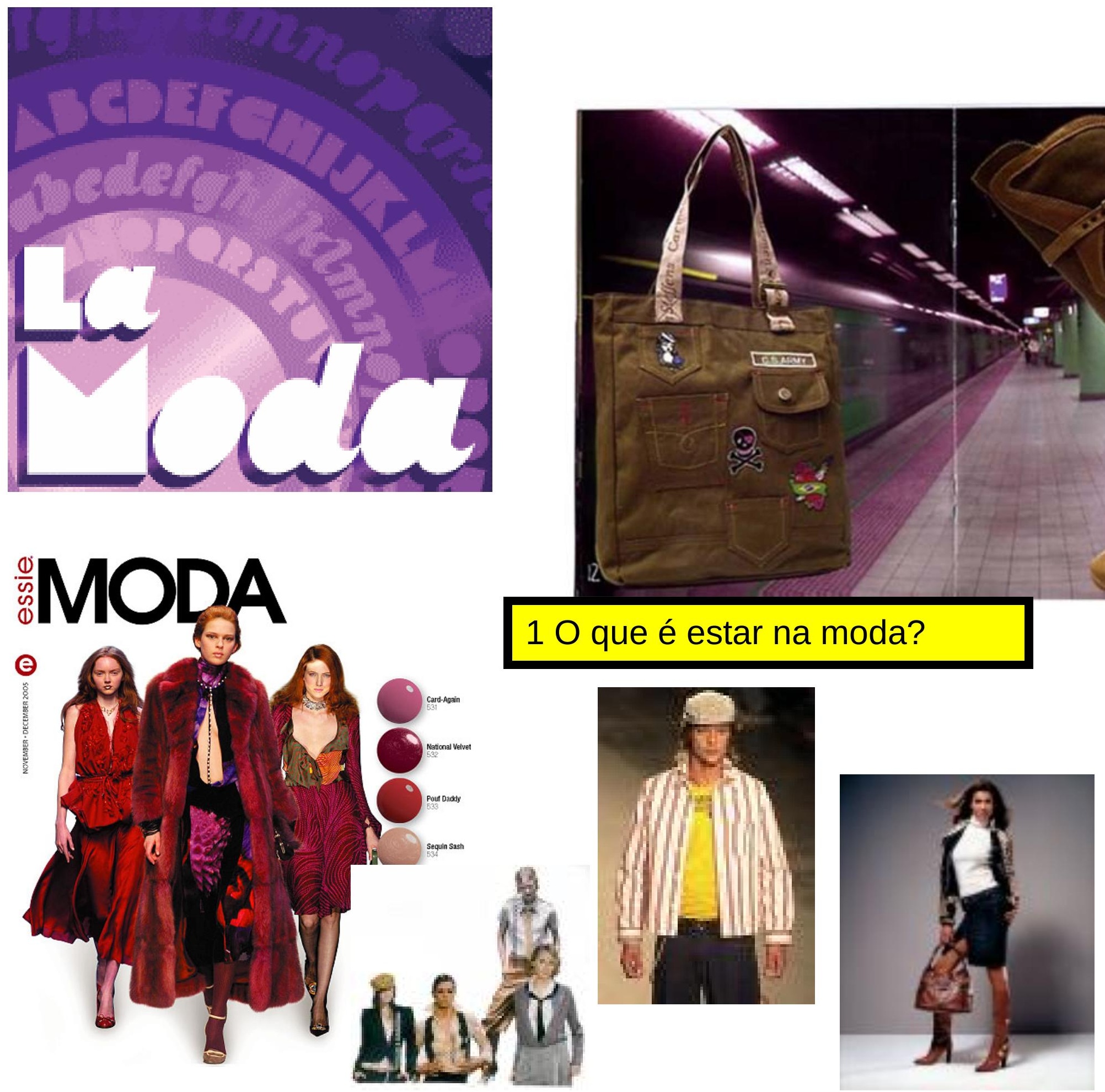

que é estar na moda?
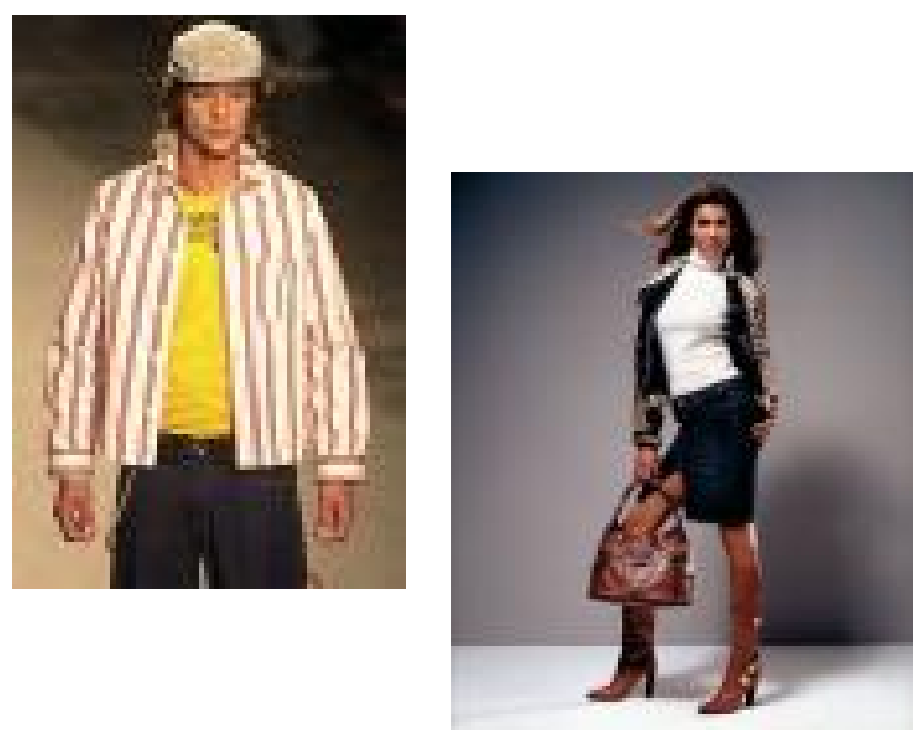


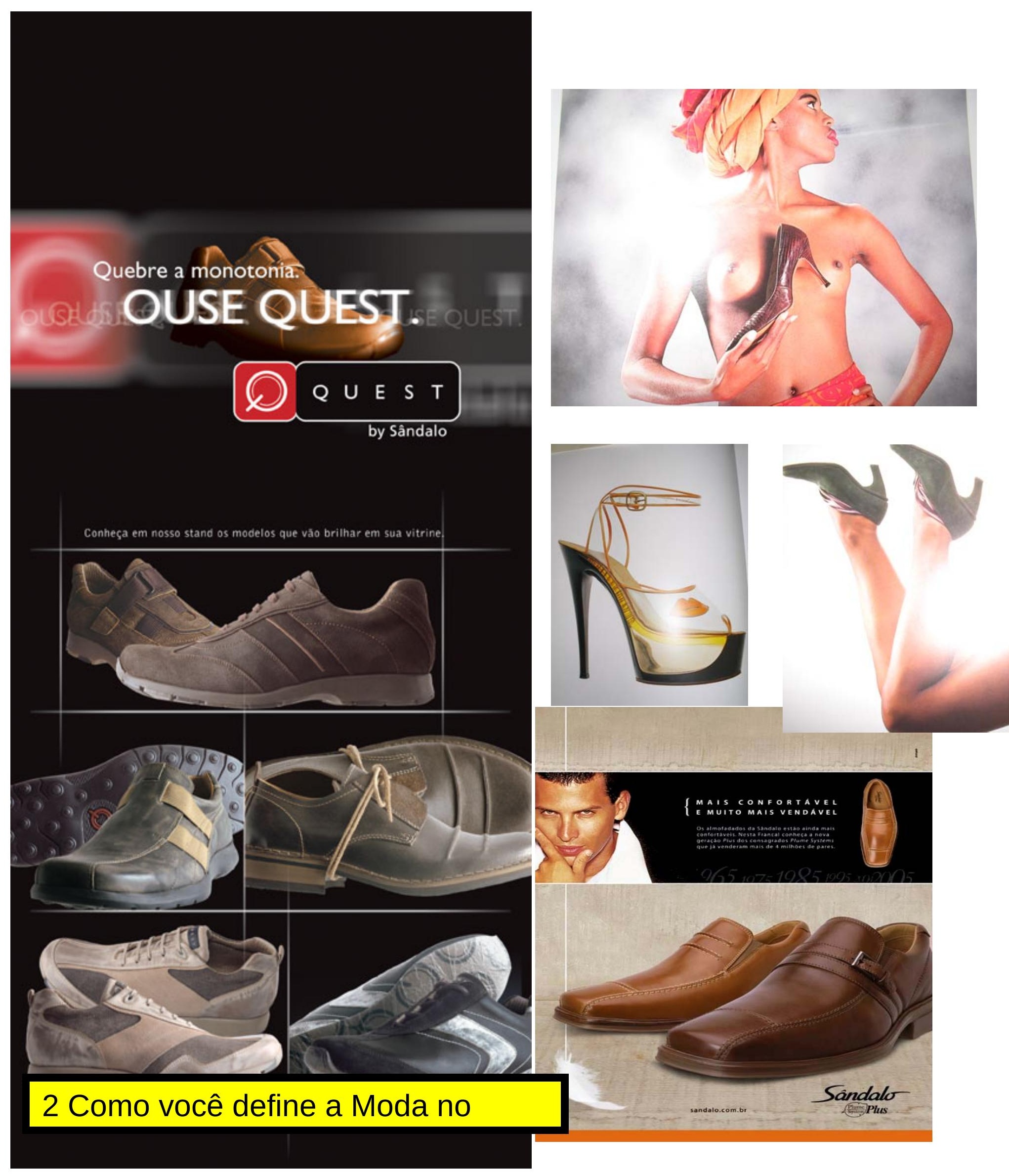



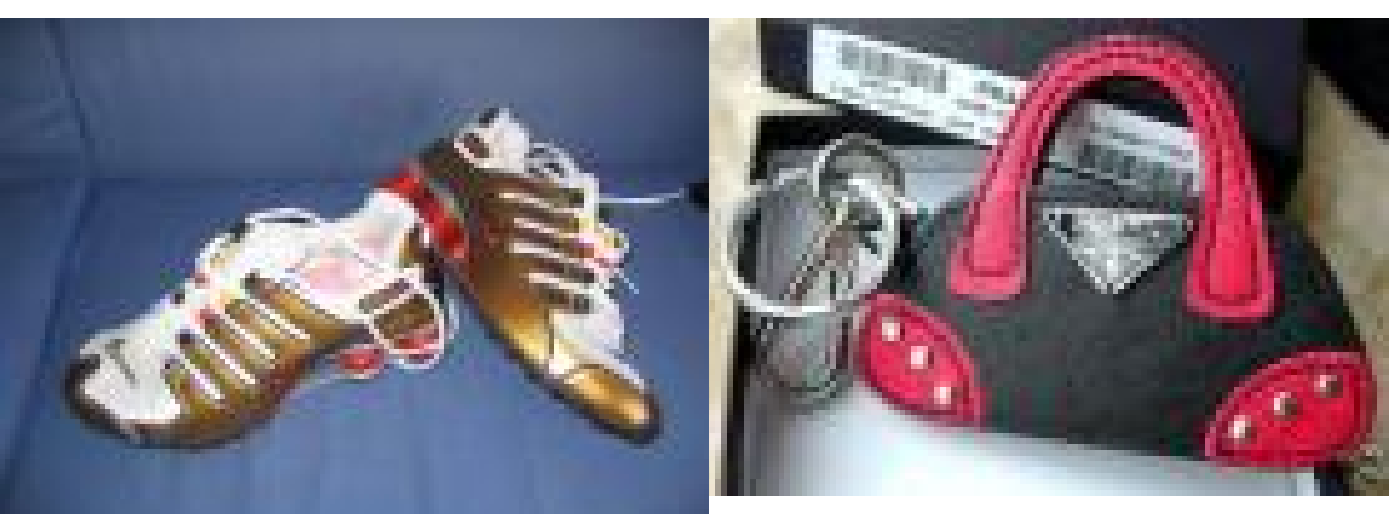

3 Estar na moda é usar calçado de marca?
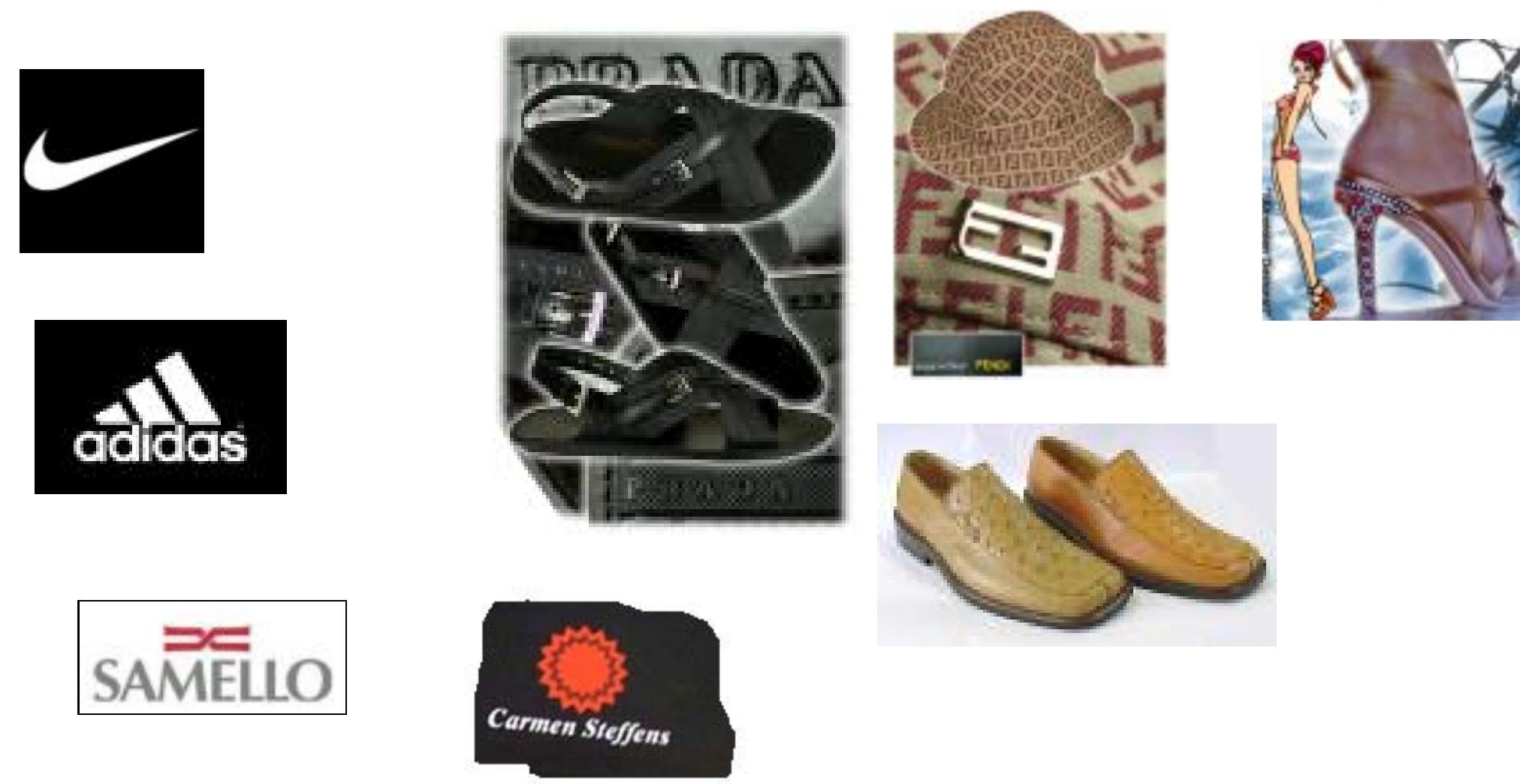

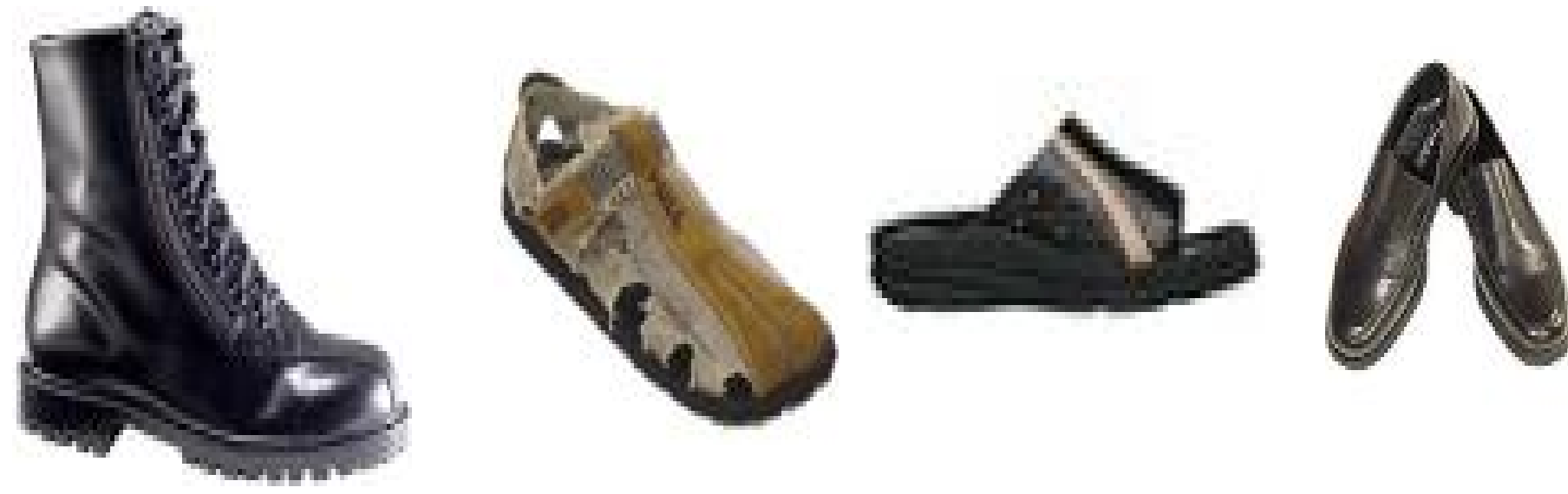

4 Quais são os elementos que caracterizam uma marca de calçado?
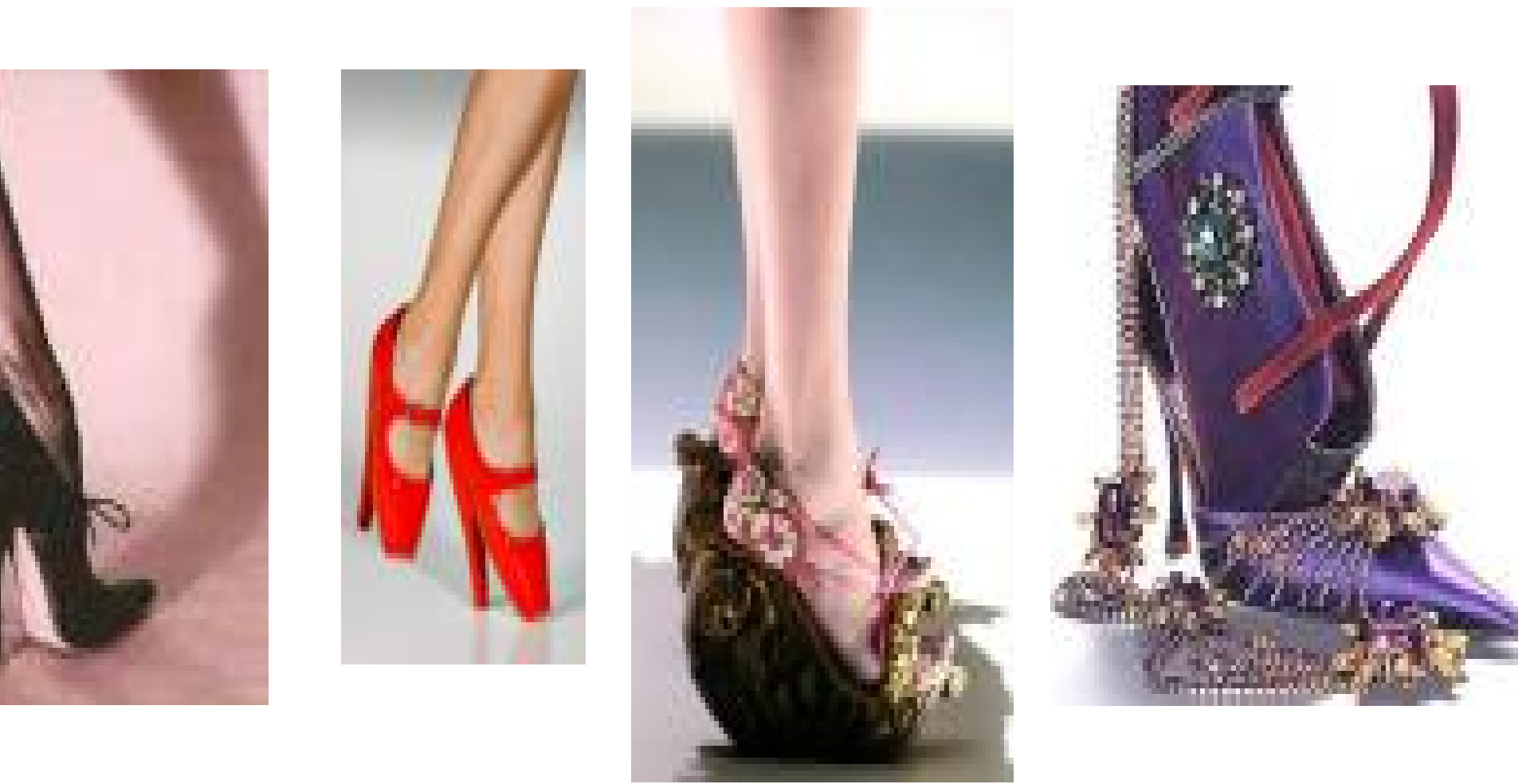

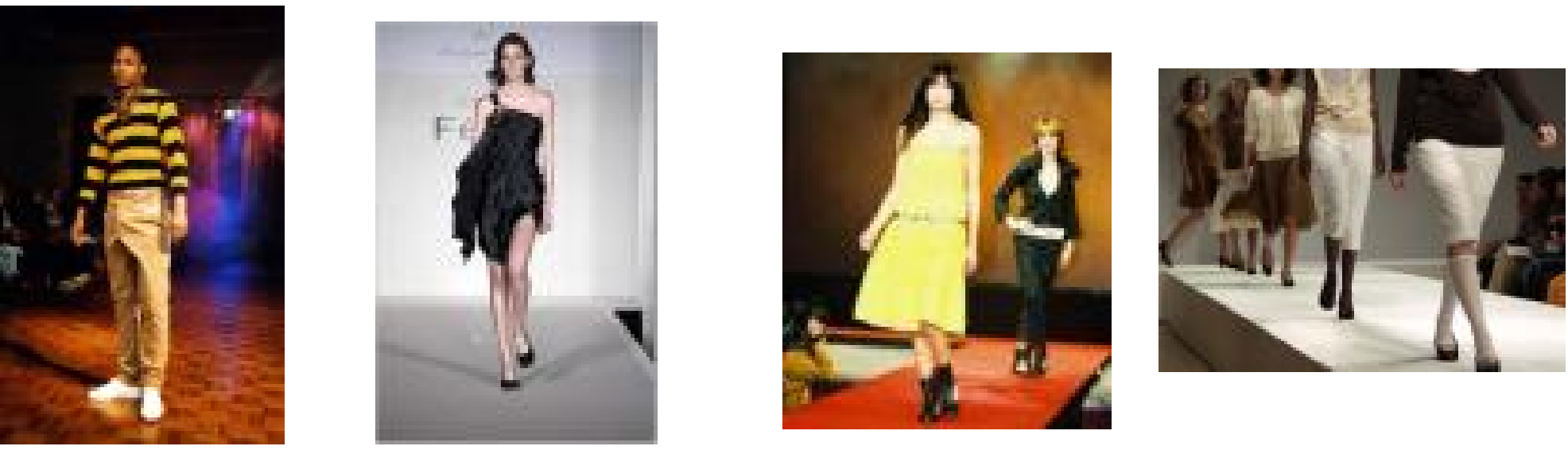

5 Qual o significado do calçado de marca?
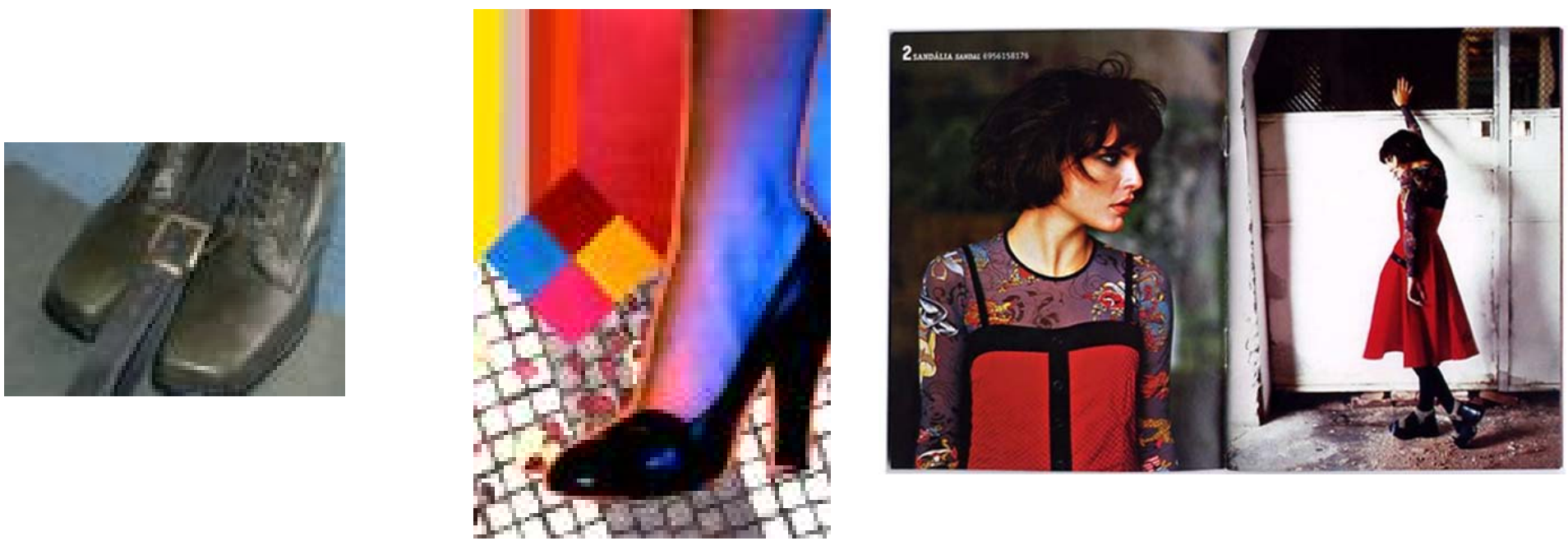

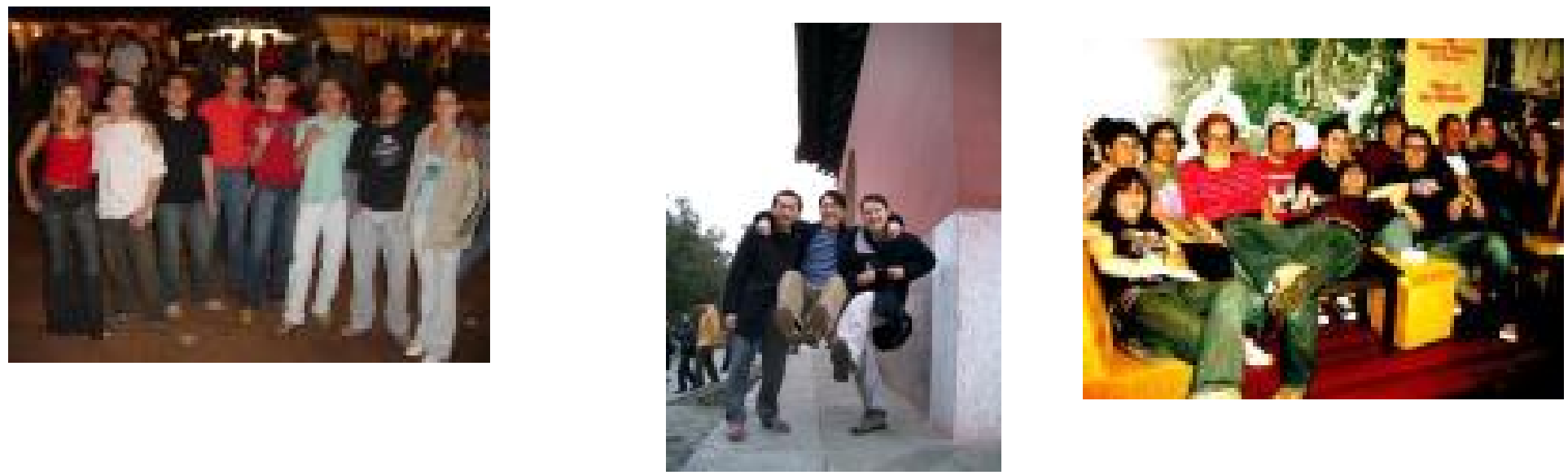

6 Quais são os papéis assumidos pelas marcas de moda e quais são suas influências na vida de um jovem?
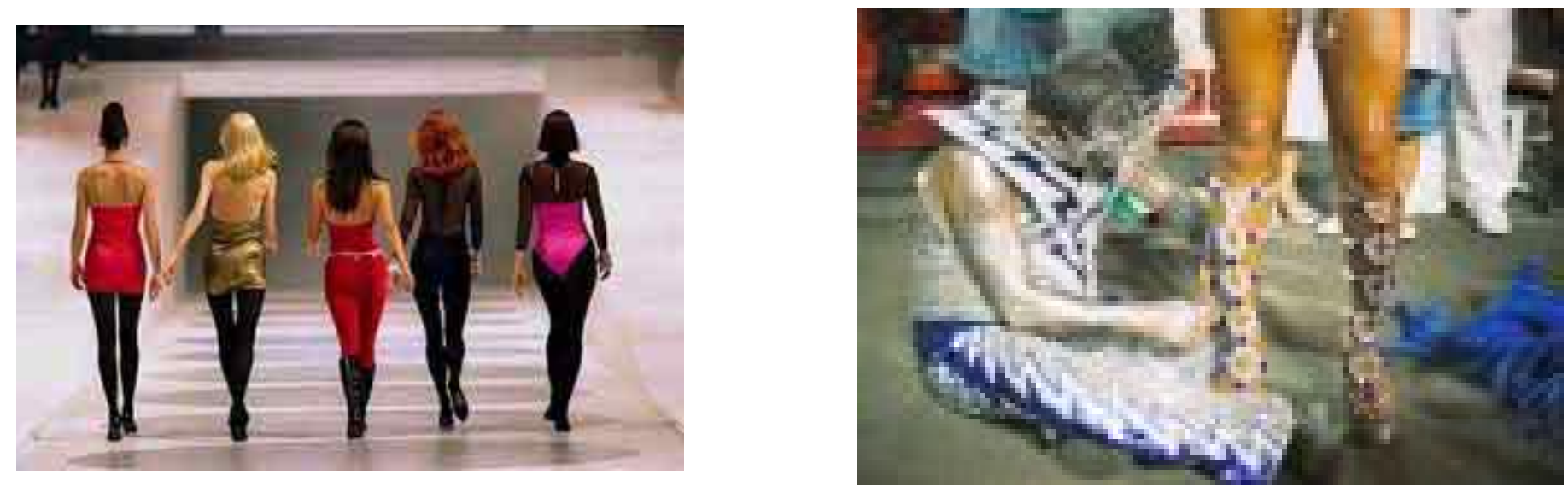

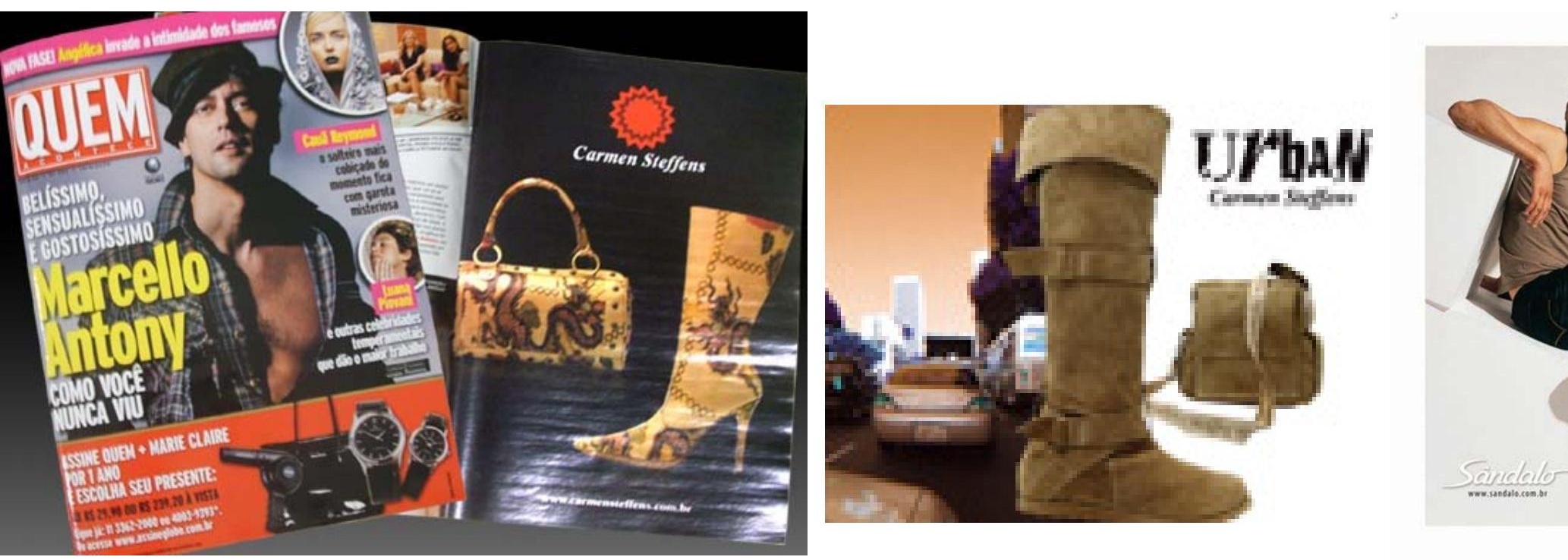

7 Quais são as relações entre os jovens e as marcas de calçados expostos pelos anúncios de calçados Veiculados nas revistas de moda?
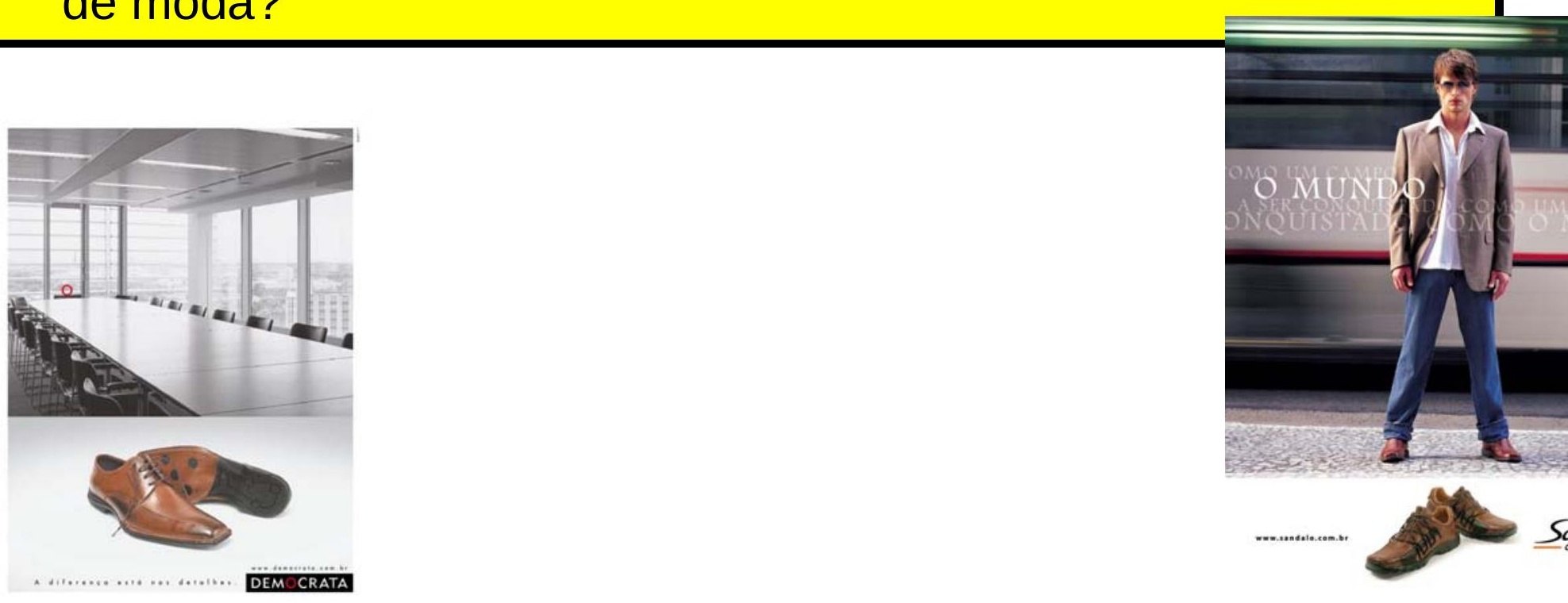

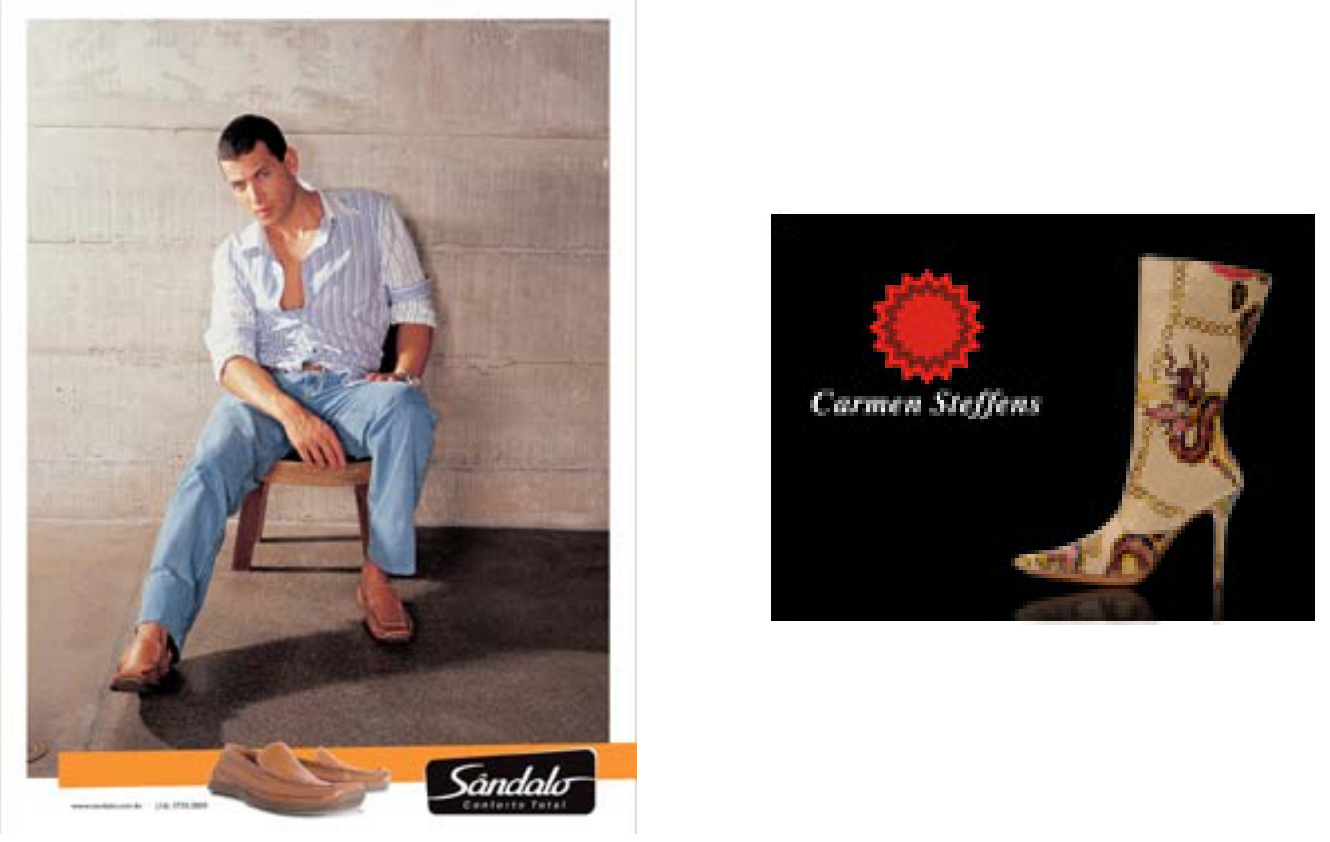

8 Como a propaganda divulga a moda? Como ela atinge 0 jovem?
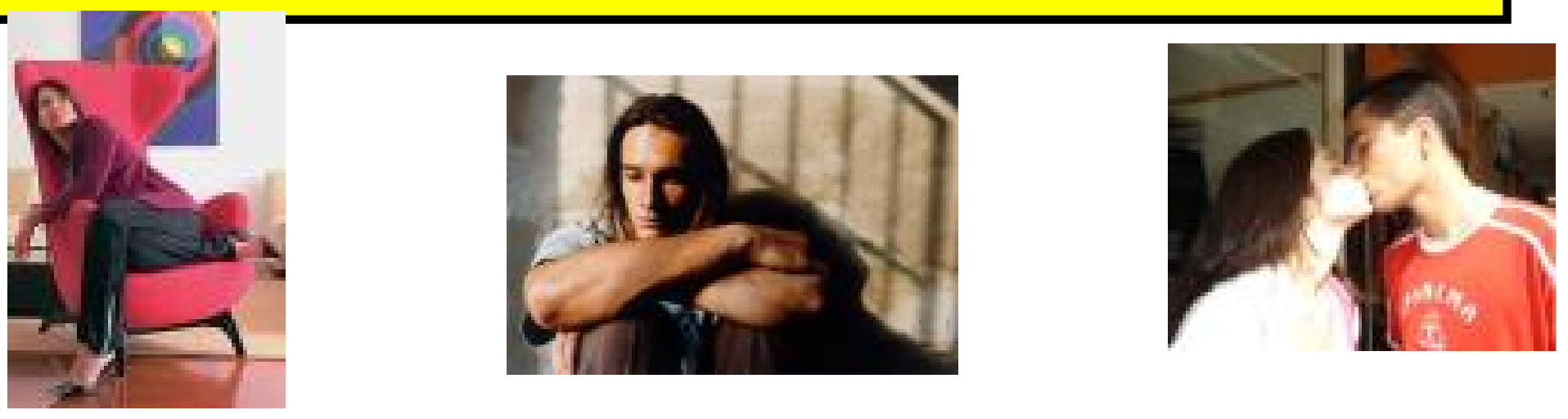


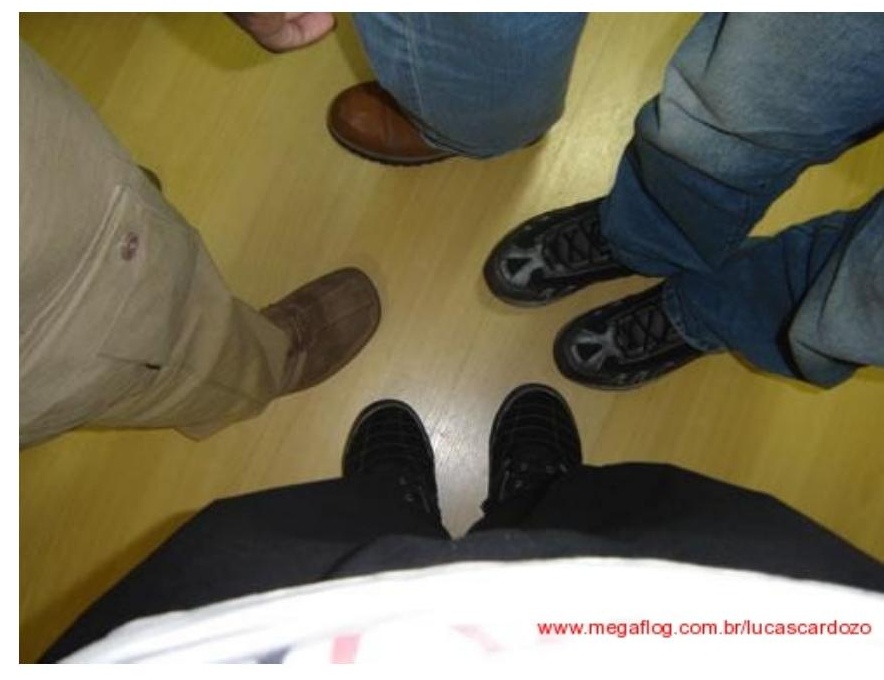

9 Qual o papel social da propaganda da moda de calçados?
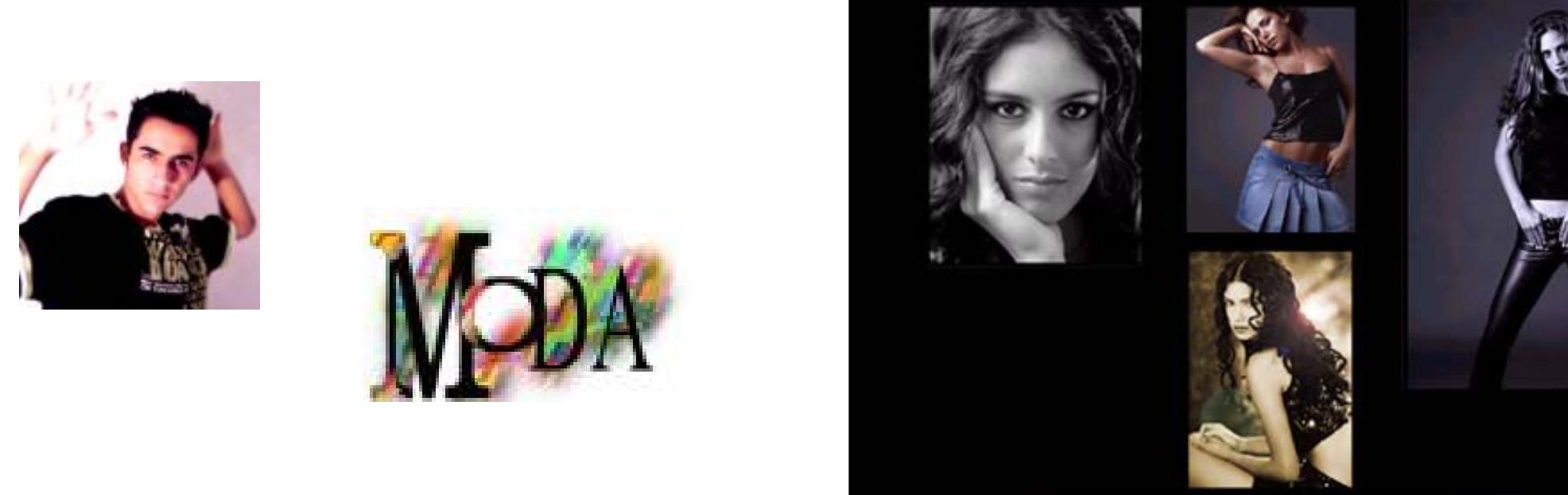

Mando Martins 

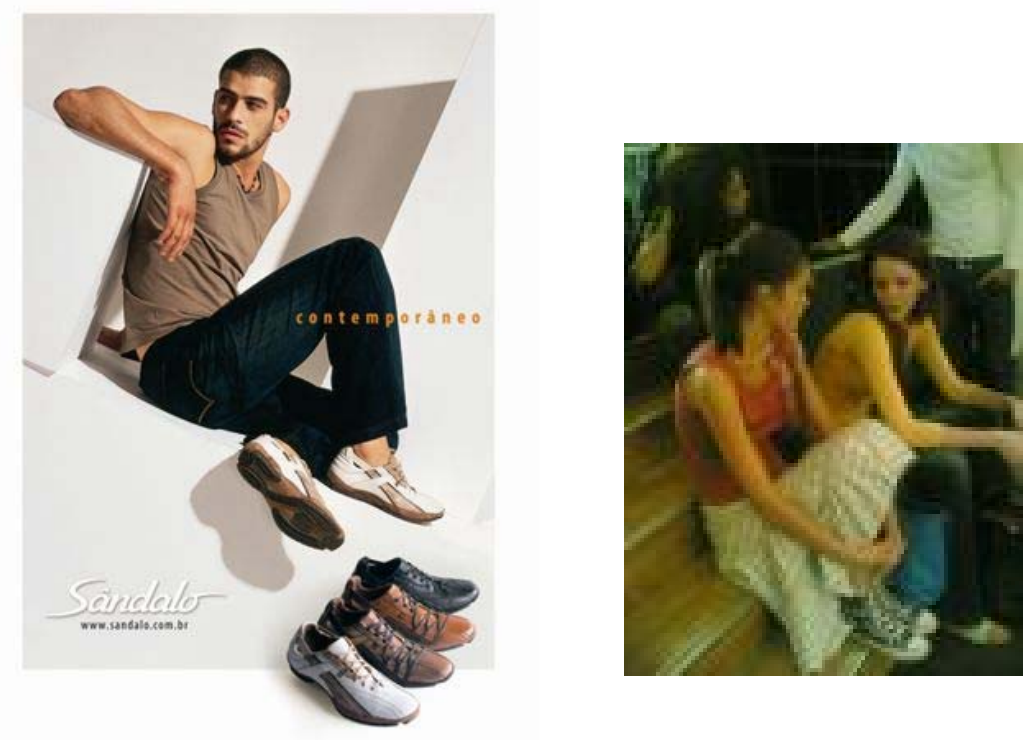

10 Qual a influência da propaganda da moda de calçados junto a um jovem?
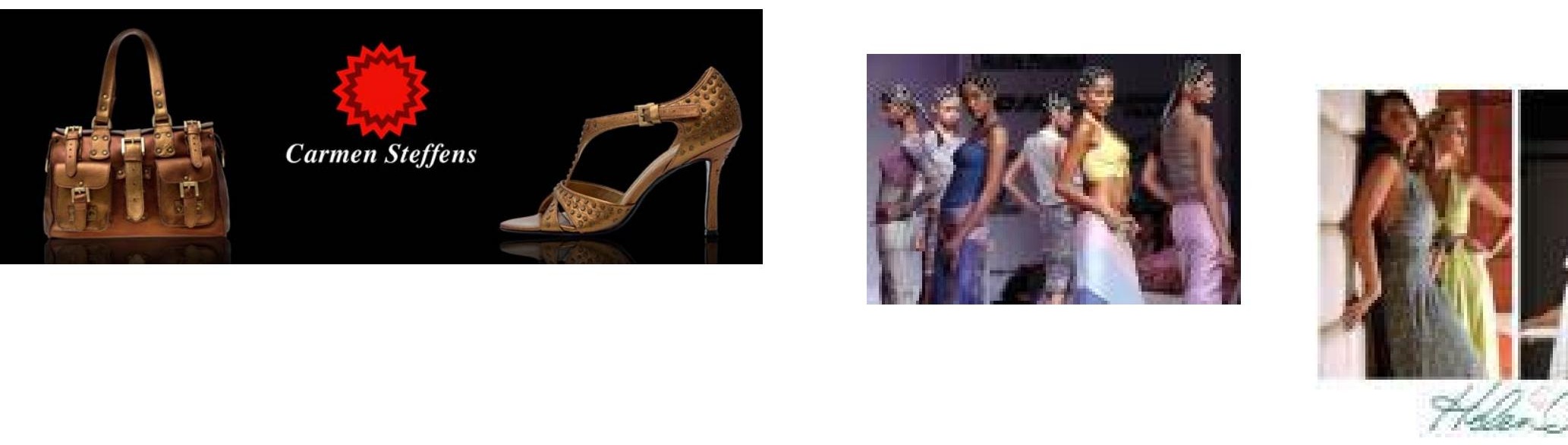
